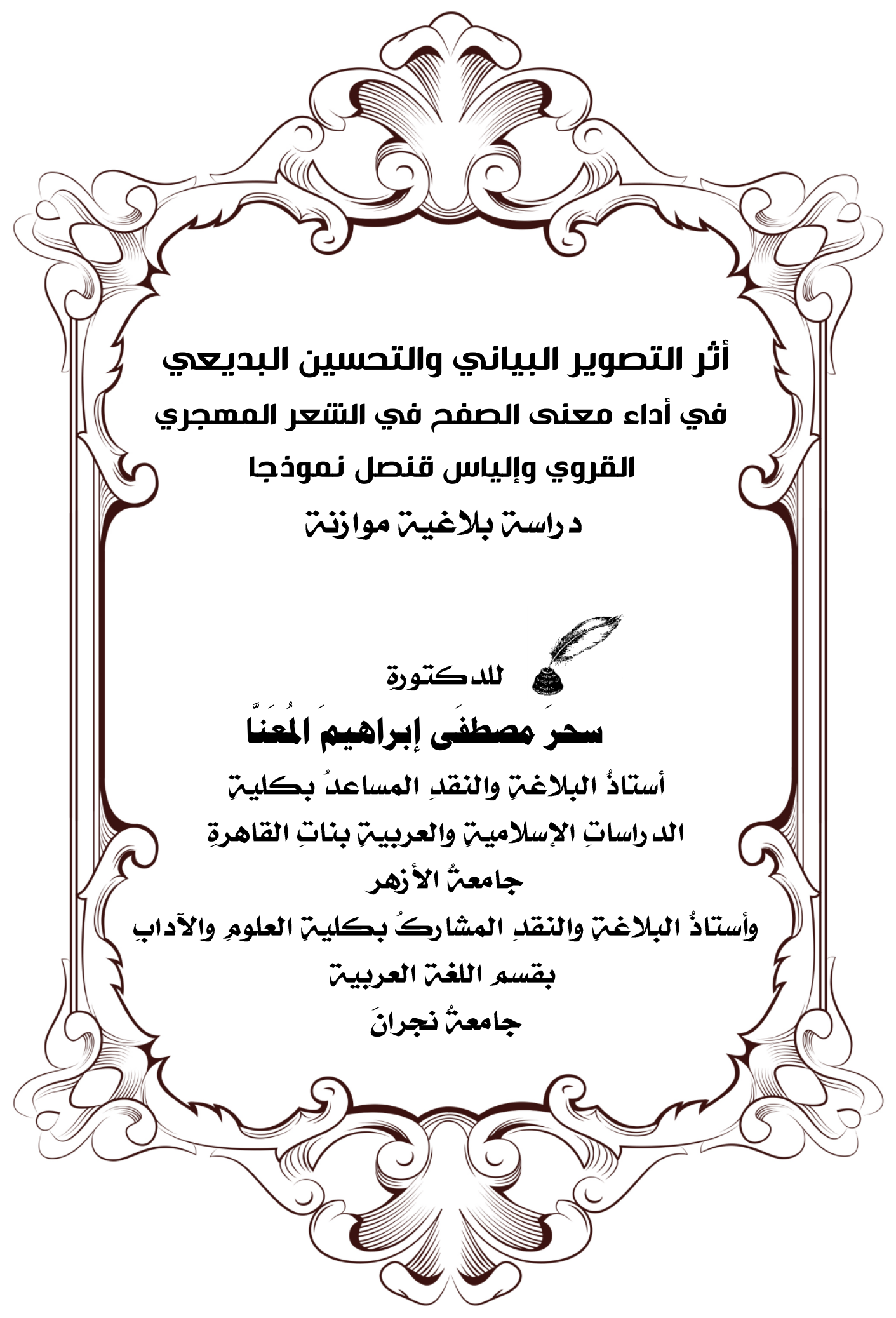



أثر التصوير البياني والتحسين البديعي ِِّْ أداء معنى الصفح ِِّ الشعر المهجري: القروي وإلياس قنصل نموذجا - دراست بلاغيتة موازنت

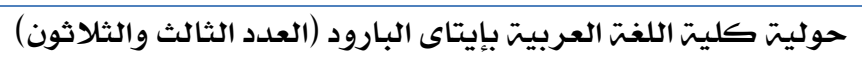

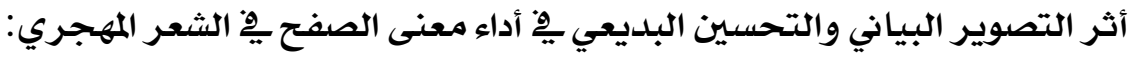

القروي وإلياس قنصل نموذجا - دراست بلاغيت موازنت

ستحر مصمطفى إبراهيهر المُحَنَّا

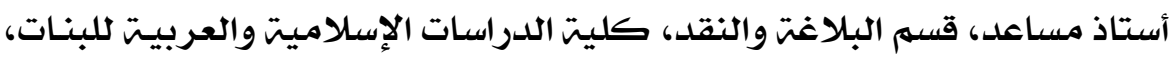

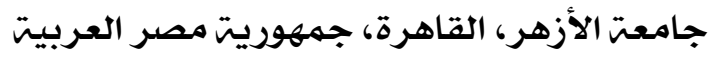
البريد الإكتروني: smalmoana@nu.edu.sa

ملخص البحثث

أسباب اختياري لموضوع البـحث:

() يتميز الثـعر المهجـري باحتوائه على النزعـة الإنسـانية الثـاملة التي تتركز في نشـر المثل العليـا والمبـادئ السـامية، وقد دفعني هـذا إلى البحث في هذا الثعر ومعايثـة أحد معانيه الراقية ( الصفح والتسـامح) معايشة روحية، وتناولها بالدراسة البيانية البديعية.

ب) مـن أكثر الأشـياء الملحوظـة في الثـعر المهجـري: براعـة التصـوير، وخصـوبة الخيال، والقدرة المتميزة في توظيف الفنون البدعيـة توظيفًا يُيرِز المضدون المعنوي والقالب الثكلي للنص، فأردت أن أتعرف على تلك المقدرة الفائقـة وتلك الميـزة المبهرة مـن خـلال معنى الصـفح في القصيدتين.

ب) لـم يتـاول أحد في مـا أعلم معنى الصـفح في شعر المهجر بالدراسـة البيانية أو البديعية، فأردت أن أتتاول هذا المعنى الراقي بتلك الدراسـة؛ لأُجِلِي براعة الشاعرين التصويرية وقدرتهما الفنية في توظيف المحسن البديعي لإخراج هذا المعنى. 
أثر التصوير البياني والتحسين البديعي ِِِ أداء معنى الصفح ِِّ الشعر المهجري: القروي وإلياس قنصل نموذجا - دراست بلاغيتة موازنت

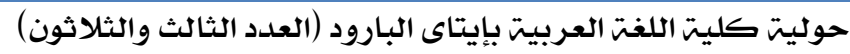
أهداف البحث:

() التعرف على النمط التصويري والثكل البديعي عند الثاعرين خصوصـا في معنى الصفح، وكيف أنهما وظفا الصـور البيانية والفنون البديعيـة في تجلية معنى الصفح.

r) اسـتخراج الصـور البيانيـة والمحسـنات البديعيـة وبيـان أثرهمـا في أداء معنى الصفح في القصيدتين.

ب) إبراز البراعة التصويريـة، والقدرة الفنية في توظيف الفنون البديعية لدى الشاعرين في معنى الصفح من خلال القصيدتين. ع) إيضاح دور الصورة البيانية والفن البديعي في إخراج مكنونات الثاعرين من معاني وأفكار . منهج البـحث: المنهج التحليلي التأملي. تقمسيه اللد راسنه

مقدمـة : وتشـمل: عنـوان البحـث وأسـباب اختيـاره والهـدف مسن وراء اختيـاره وخطته ومنهجه. تمهيـد: ويشـل: البواعث التي حدت بشعراء المهجر إلى التحلـي بـالقيم، والمناداة بالتمسك بالمبادئ السامية - نبذة مختصرة عن الثاعرين. المبـحسث الأول: أثر التصـوير البياني في أداء معنى الصـفح بين القروي وإلياس قنصل - دراسة بلاغية موازنة المبحسـث الثـاني: أثر التحسين البديعي والنغم الموسيقي في أداء معنى الصفح بين القروي وإلياس قنصل-دراسة بلاغية موازنة. المبـحث الثاثث: سمات التصوير البياني والتحسين البديعي في أداء معنى الصفح بين: القروي وإلياس قنصل. الخاتهمٌُ: وتشملُ النتائجَ المهرةَ والتوصياتِ. 
أثر التصوير البياني والتحسين البديعي ِِّ أداء معنى الصفح ِِّ الشعر المهجري: القروي

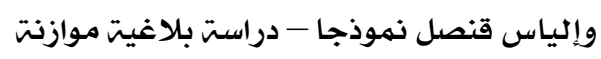

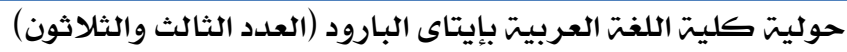

الفهارسُ: تشمل: فهرسُ المصادرِ والمراجعِ - فهرسُ الموضوعاتِ.

الكلمات المفتاحية للبحث:

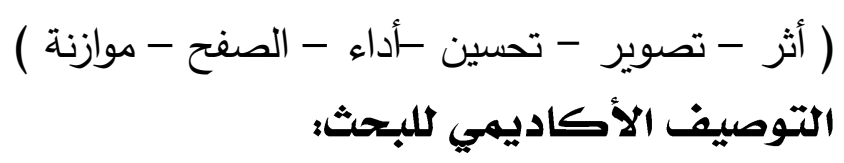

القسم: اللغة العربية.

التخصص: البلاغة والنقد.

النوع: بلاغة موازنة.

وصلى اللهم وبارك على محمد، وآله وصحبه أجمعين. 
أثر التصوير البياني والتحسين البديعي فِ أداء معنى الصفح بِّ الشعر المهجري: القروي

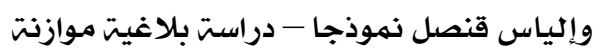

حوليت كليت اللغت العربيت بإيتاى البارود (العدد الثالث والثلاثون) موانسان

"The Effect of Graphic Imaging and "The Impact of Rhetorical Imaging and Literary Figures of Speech Usage in Portraying the Meaning of Forgiveness in the Poetry of Diaspora : Al-Qarawi and Elias Consol Model - A Comparative Rhetorical Study" .

Reasons for selecting the topic:

Researcher name: Sahar Mustafa Ibrahim AlMoana.

Private Email:DR.SAHAR52015@GMAIL.COM

Academic Email:smalmoana@nu.edu.sa

Assistant Professor, Department of Rhetoric and Criticism, Faculty of Islamic and Arab Studies for Girls, Al-Azhar University, Cairo, Arab Republic of Egypt

Abstract:

1) Diaspora Poetry is characterized by containing a comprehensive humanitarian tendency represented in the dissemination of high ideals and principles. This has prompted me to research in this type of poetry and spiritually interact to one of its elevated meanings (forgiveness and tolerance) and address it in a rhetorical figurative based study.

2) Among the most noticeable aspects of Diaspora poetry are: the skill of imaging, fertility of imagination, and the distinct ability to employ innovative arts in a way that highlights the moral content and formality of the text. Thus, I attempt to identify this fine ability and that dazzling advantage through the meaning of forgiveness in the two poems.

3) No one has dealt, as far as I know, with the meaning of forgiveness in Diaspora poetry was with a rhetorical study. So, I wanted to address this high-end meaning with the current study, in order to expose the rhetorical imaging of the two poets and their artistic 
أثر التصوير البياني والتحسين البديعي فِ أداء معنى الصفح فِ الشعر المهجري: القروي

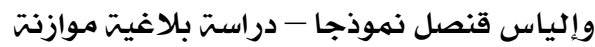

حوليت كليت اللغت العربيت بإيتاى البارود (العدد الثالث والثلاثنانيان

ability to employ figures of speech to produce this meaning.

\section{research goals:}

1) Identifying imagery and figurative style of the two poets, especially in elucidating the meaning of forgiveness, and how they employed rhetorical images and exquisite figures of speech in manifesting the meaning of forgiveness.

2) Singling out the rhetorical images and the figures of speech, and explaining their effect on depicting the meaning of forgiveness in the two poems.

3) Highlighting the the rhetorical imaging proficiency and the artistic ability to employ the figurative art of the two poets pertaining to the meaning of forgiveness through the two poems.

4) Clarifying the role of rhetorical image and figurative language in the exclusivity of the impliedd meanings and ideas of the two poets.

\section{Research methodology:}

Reflective analytical method.

\section{Research division:}

Introduction It includes the title of the research, reasons for its selection, the goal behind its selection, its plan and methodology.

Prelude: It includes the motives that led the poets of the Diaspora to show values and call for adherence to the noble principles - a brief outline of the two poets.

\section{The first topic:}

The impact of rhetorical imaging in portraying the meaning of forgiveness between Al-Qarawi and Elias Consol a Rhetorical comparative study. 


$$
\begin{aligned}
& \text { أثر التصوير البياني والتحسين البديعي فِ أداء معنى الصفح هٍُ الشعر المهجري: القروي }
\end{aligned}
$$

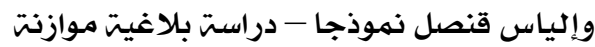

$$
\begin{aligned}
& \text { حوليت كليت اللغت العربيت بإيتاى البارود (العدد الثالث والثلاثون) }
\end{aligned}
$$

The second topic:

The effect of figures of speech usage and musical tone on envisaging the meaning of forgiveness between Al-Qarawi and Elias Consol- a Rhetorical comparative study.

\section{The third topic:}

Characteristics of rhetorical imaging figures of speech usage in portraying the meaning of forgiveness between Al-Qarawi and Elias Consol-

Conclusion: includes important results and recommendations.

Indexes: - Sources and References Index -Index of topics.

Search keywords :(Impact - Imaging- Figurative language - Portraying - Forgiveness - Comparative)

\section{Academic specification of the research:}

Department: Arabic Language.

Specialization: rhetoric and criticism.

Major: Comparative

Rhetoric.

"May Allah bless Muhammad and his entire family and companions". 
أثر التصوير البياني والتحسين البديعي هِّ أداء معنى الصفح هٍِ الشعر المهجري: القروي

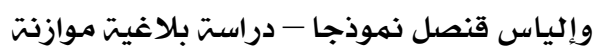

حوليت كليت اللغت العربيت بإيتاى البارود (العدد الثالث والثلاثون)

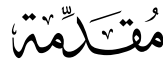

الحمد الله الذي بحمدهِ تدومُ النعُُ، وبنعمتهـه تتم الصـالحات، وبرحمتِِهِ

علمَ الانسـان مـا لم يعلم، والصـلاة والسـلام على عبده ورسولِِهِ محمد مخرج

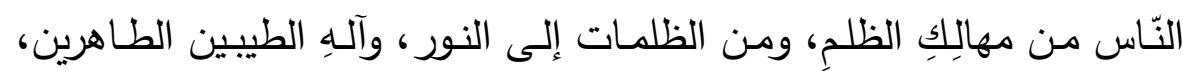
وصحابتِهِ الاخيار ومن سار على دربهم، ومن تبعهم بإحسان إلى يوم الدين.

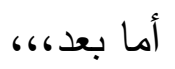

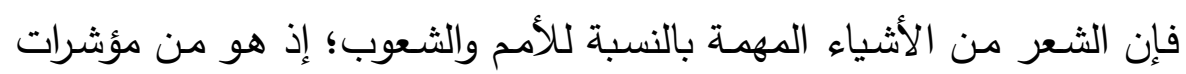

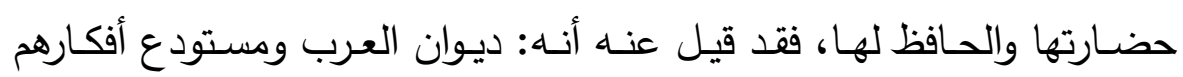
ومقتني أحلامهم.

والخيال عُنصرٌ مهم في تثكيل الصورة البيانية ورسمها في الثعر ، بل هو تلك العملية المؤدية إلى تثكيل الصورة البعيدة عن الواقع أو التي قد تكون من محض الخيال، فإن للخيال القدرة على تقريب البعيد وابعاد القريب والربط

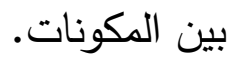

والمحسنات البديعية من الوسائل التي يستعين بها الأديب لإظهار مشاعره وعواطفه، وللتأثير في النفس، وهذه المحسنات تكون مؤثرة رائعسة إذا كانت قليلة ومؤدية للمعنى الذي يقصده الأديب، أما إذا جاءت كثيرة ومتكلفة فقدت وهده جمالها وتأثيرها وأصبحت دليل ضعف وديه الأسلوب، وعجز الأديب.

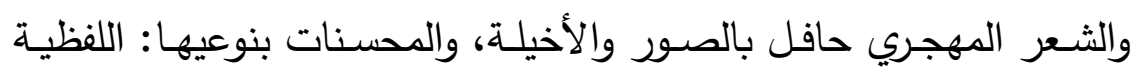
منها والمعنوية، ومع هذا ففي معظمه يخلو من الصنعة والتكلف ، فبات رقيقًا جزلًا، وهذا يرجع الى رد العمل الى النفس والوجدان. ولمــا للخيـال مـن ضـرورة فعليـة في تحقيق وتجسـيد الصـورة البيانيـة، ولمــا للتصوير البياني والتحسين البديعي من الأثر البارز في أداء المعاني السامية والقيم الخُلُقية في شعر المهجر ، آثرت العمل في بحث تحت عنوان: " أثر الثر 
أثر التصوير البياني والتحسين البديعي هِّ أداء معنى الصفح فِ الشعر المهجري: القروي

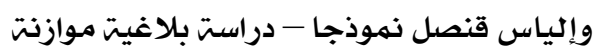

$$
\text { حوليت كليت اللغت العربيت بإيتاى البارود (العدد الثالث والثلاثونة موارنة }
$$

التصـوير البيـاني والتحسـين البـديعي في أداء معنـى الصـفح فـي الثــر

المهجري: القروي وإلياس قنصل نموذجا - دراسة بلاغية موازنة. "

ومن أسباب اختياري لهذا الموضوع:

ع) يتميز الثـعر المهجري باحتوائـه على النزعـة الإنسـانية الثـاملة التي تتركز في نشـر المثل العليا والمبـادئ السـامية، وقد دفعني هذا إلى إلى البحث في هذا الثعر ومعايشة أحد معانيه الراقية ( الصفح والتسامح) معايثة روحية، وتتاولها بالدراسة البيانية البديعية •

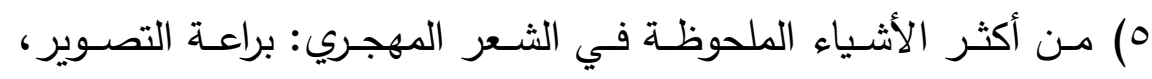
وخصـوبة الخيال، والقدرة المتميزة في توظيف الفنون البدعيـة توظيفًا

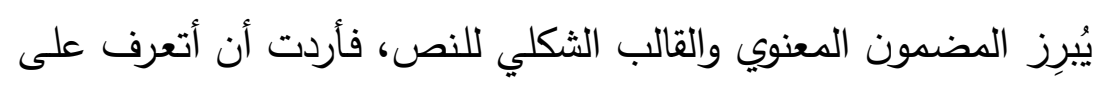

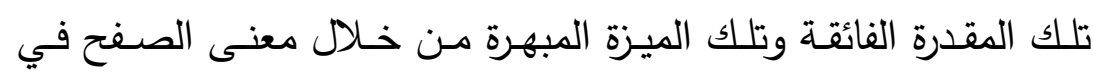
- القصيدتين

ج) لـم يتتاول أحد في مـا أعلم معنى الصفح في شعر المهجر بالدراسـة

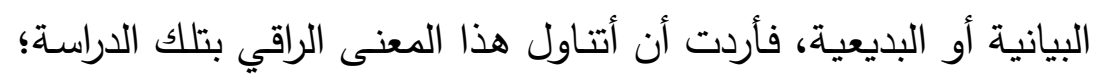

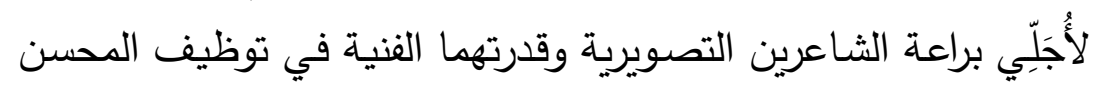

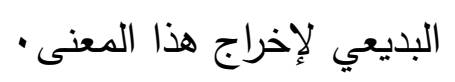

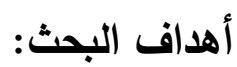

() التعرف على النمط التصويري والثكل البديعي عند الثاعرين خصوصا في معنى الصفح، وكيف أنهما وظفا الصور البيانية والفنون البديعية

$$
\text { في تجلية معنى الصفح. }
$$

r) اسـتخراج الصـور البيانيـة والمحسـنات البديعيـة وبيـان أثرهمـا في أداء معنى الصفح في القصيدتين ·

r) إبراز البراعة التصويرية، والقدرة الفنية في توظيف الفنون البديعية لدى الثاعرين في معنى الصفح من خلال القصيدتين. 
أثر التصوير البياني والتحسين البديعي هِّ أداء معنى الصفح هٍِ الشعر المهجري: القروي

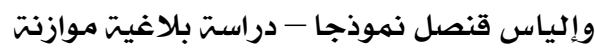

حوليت كليت اللغت العربيت بإيتاى البارود (العدد الثالث والثلاثون)

ع) إيضاح دور الصورة البيانية والفن البديعي في إخراج مكنونات الثاعرين البرودين

• من معاني وأفكار

هذا وقد نهجت المنهج التحليلي التأملي في هذا البحث، حيث قمت ولت

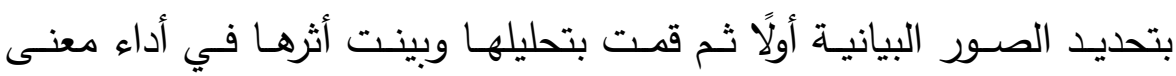

الصفح.

كـذلك قمـت باسـتخراج المحسـنات البديعيـة بنوعيهـا المعنويـة منهـا

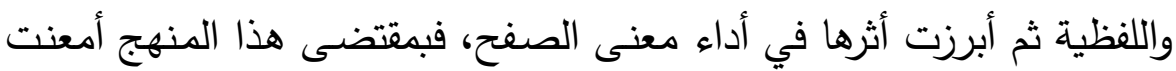
النظر في القصيدتين، واستطعتُ أنْ أتأمل الصور البيانية والمحسنات البديعية

وأبينَ نوعَهما وسرَّهَما البلاغِي.

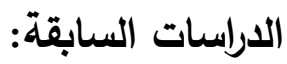

لقد تعرض الشعر المهجري لدراسـات كثيرة لكن معظم الدراسـات التي

تتاولت شعر المهجر الجنوبي كانت دراسـات أدبية، ولم تقرد للقيم والأخلاق حديثاً مستقلاً بل كان ذكرها للقيم ذكراً هامشياً، كما أنني لم أجد في ما أعلم

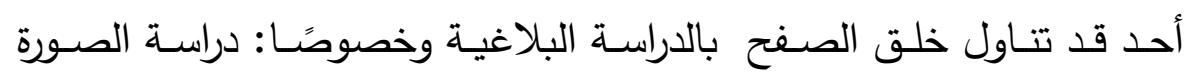
البيانية والمحسنات البديعية إن البية

ومن الدراسات الأدبية التي تعرض لها الثعر المهجري: دراسة الدكتور /

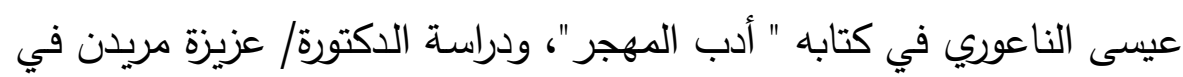
كتابها "القومية والإنسانية في شعر المهجر الجنوبي"، ودراسـة الدكتورة/ نعيمة مراد في كتابها " العصبة الأندلسية هجرة الأدب العربي إلى البرازيل"، ودراسة

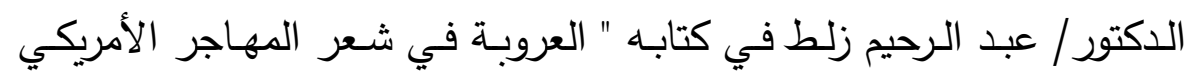
الجنوبي"، ودراسة الدكتور/ عمر الدقاق في كتابه " شعراء العصبة الأندلسية في المهجر"، فقد حوت هذه الدراسات الكثير من التفاصيل حول تأجج القومية في نفوس هؤلاء الثعراء، ودعوتهم إلى المحبة الخالصـة من كل شائبة، تلك هل التي يندرج تحت لوائها التمسك بالفضائل، والمناداة بتجنب الرذائل، دون دراسة 
أثر التصوير البياني والتحسين البديعي فِّ أداء معنى الصفح مِّ الشعر المهجري: القروي

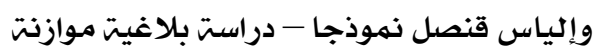

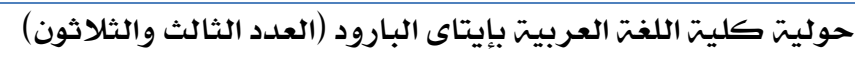

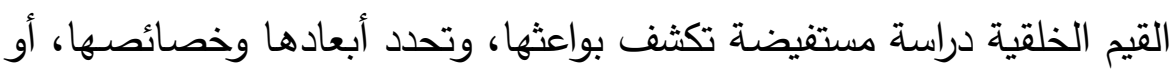

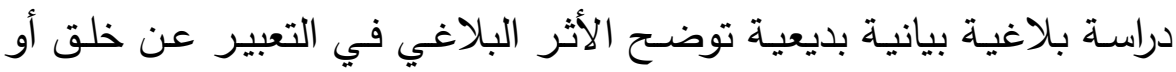

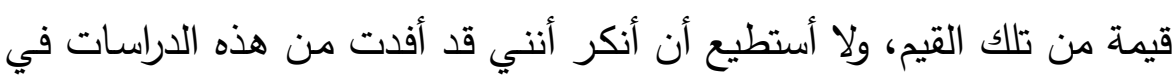

$$
\text { تقثير من جوانب بحثي. }
$$

مقدمة: وتثمل: عنوان البحث وأسباب اختياره والهدف من وراء اختياره وخطته

ومنهجه.

تمهيد: ويشمل:

البواعث التي حدت بشعراء المهجر إلى التحلي بالقيم والتمسك بالمبادئ السامية - نبذة مختصرة عن الثاعرين • المبحث الأول: أثر التصوير البياني في أداء معنى الصفح بين القروي وإلياس قنصل - دراسة بلاغية موازنة

المبحث الثاني: أثر التحسين البديعي والنغم الموسيقي في أداء معنى

الصفح بين القروي وإلياس قنصل-دراسة بلاغية موازنة .

المبحث الثالث: سمات التصوير البياني والتحسين البديعي في أداء

معنى الصفح بين: القروي وإلياس قنصل •

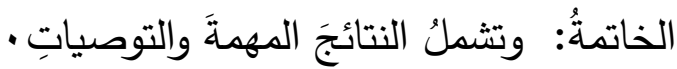

الفهارسُ: وتشمل: فهرسُ المصادرِ والمراجع - فهرسُ الموضوعاتِ. هذا وقد استقيت بحثي هذا من الكتب البلاغية وكتب اللغة والأدب ومَا توفيقِي إلَّا باللهِ عليهِ توكلتُ وإليهِ أنيبُ هُبْ 
أثر التصوير البياني والتحسين البديعي فِّ أداء معنى الصفح بِّ الشعر المهجري: القروي

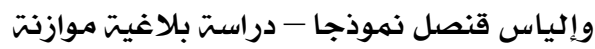

حوليت كليت اللغت العربيت بإيتاى البارود (العدد الثالث والثلاثون)

تمهيد:

البواعث التي حدت بثـعراء المهجر إلى التحلـي بـالقيم والتمسك بالمبادئ

السامية: - (n)

أولًا الفطرة:

الفطرة هي: صفاء التكوين في الإنسان، والجِيلَّة الصـافية التي خلق

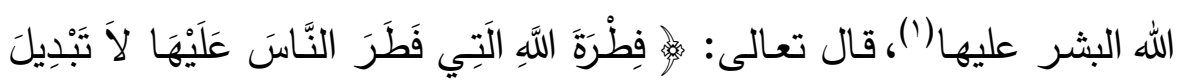

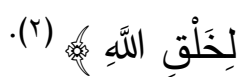

ولقد فطن الباحثون إلى أهمية الفطرة كمصدر للإلَزام الخُلُقي، وباعثٍ

من أهم بواعثه، وللإسلام نظرة ربانية في ولادة الإنسان على الفطرة صافياً نقياً

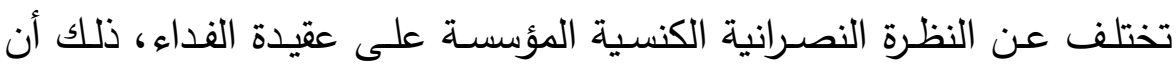
الإنسان في النصرانية الكنسية يولد والخطية (ז)في دمـه، فالمعتقد النصراني أن الشر متمكن في النفوس البشرية، " وأن إرادة الإنسان قد فسدت واستعبدت

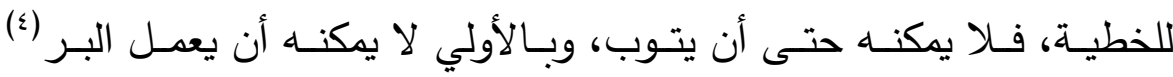
الضروري للخلاص، وفي الكتاب المقدس كثير من الثواهد التي تبين عمومية

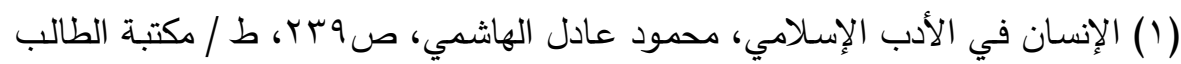

$$
\begin{aligned}
& \text { الجامعي، العزيزية- مكة المكرمة، بدون تاريخ. } \\
& \text { سورة الروم: آية رقم (·r) (ب). }
\end{aligned}
$$

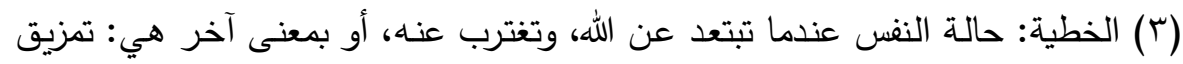
العلاقة بين الإنسان والله، أو محبة الذات بدلاً من محبة الله.

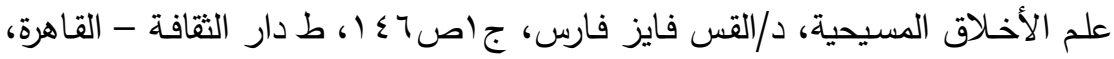
بدون تاريخ.

(ع) التبرير بالإيمان: أن يعرف الإنسان أنه لا يستطيع أن يخلص نفسه بأعماله الصالحة،

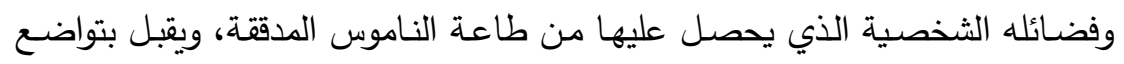

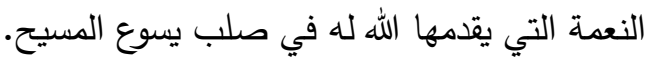

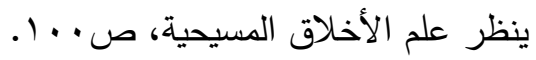


أثر التصوير البياني والتحسين البديعي فِ أداء معنى الصفح هٍُ الشعر المهجري: القروي

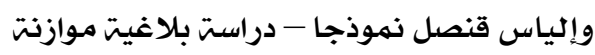

حوليت كليت اللغت العربيت بإيتاى البارود (العدد الثالث والثثلاثون)

الخطية، وتأصلها في النفس البشرية، ومعظم شعراء المهجر الجنوبي قد تأثروا بهذه المعتقدات النصرانية، وببعض النظريات الفلسفية والنفسية الحديثة التي تؤيد هذه المعتقدات وتعضدها، كآراء فرويد وغيره، والضمير الأخلاقي السليم كان باعثَ هؤلاء الثعراء القوي، ودافعهم الأكبر على التمسك بقيمهم، وإتقان

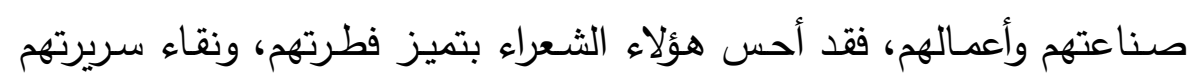
عن الجنس البشري الذي شقوه بسهام نقدهم؛ إذ رأوا الشر هو أصل فطرته، لفئ

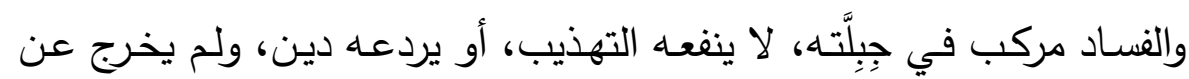

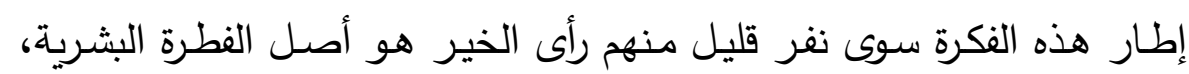

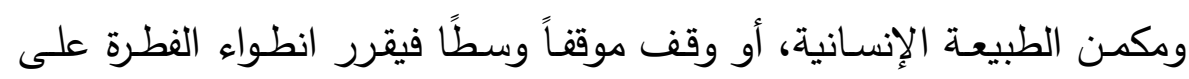
الخير والشر معاً، أما معظمهم فقد رفض العيش في هذا المجتمع الإنساني

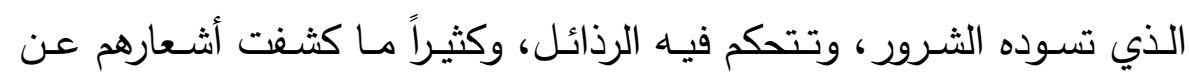
ضمائرهم الحية، وما ركب في طباعهم من قيم ومبادئ ومثل أهلتهم لمكان القيادة - - n - n ثانيًا: الوراثة: الوراثة هي: ( انتقال بعض صفات الأصل إلى الفرع، قلَّ ذلك أو كثر ... ولها أثر كبير في تكوين أخلاق الفرد وتكييفها، وطبعها بطابع معين، خيراً كان

ذلك الطابع أو شراً، حسناً أو قبيحاً)('). هذا ولا يرث الطفل عن والديه قيماً ناضجة ومتكاملة، بل يولد ولديه الاستعداد

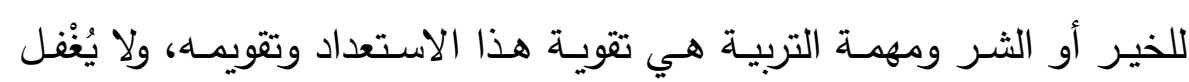
العلماء الدور البارز للدين في تزكية الأخلاق، وتتميتها في نفوس الأطفال . والوراثة عند شعراء المهجر الجنوبي كانت باعثاً هاماً من بواعث القيم الخلقية، له عظيم الأثر في تزكية نفوسهم وتهذيبها، وتخلقها بالخلق القويم، وقد ظهر باعراه

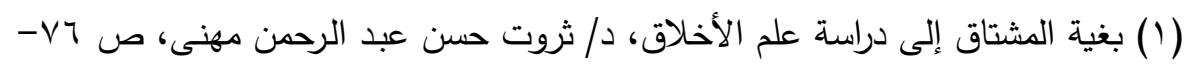

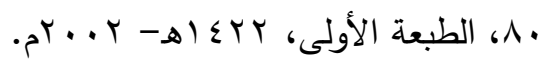


أثر التصوير البياني والتحسين البديعي هِّ أداء معنى الصفح هٍِ الشعر المهجري: القروي

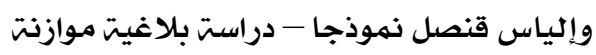

حوليت كليت اللغت العربيت بإيتاى البارود (العدد الثالث والثلاثون)

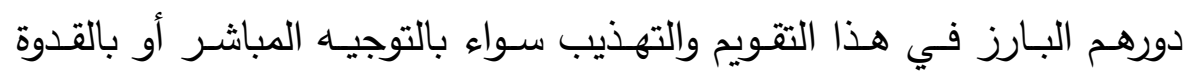

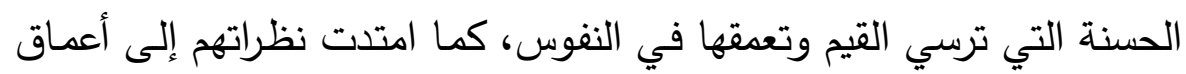
الماضي السحيق، فاستوحوا عظمة الأجداد، وما تحلوا به من أخلاق دانت لهج بعظمتها بقاع الأرض، وامتلكوا برفعتها قلوب الخلق، واتخذ منها معظمهم

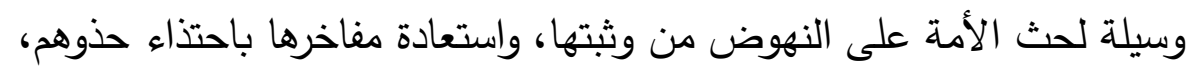
وتوارث كريم خلالهم.

فالافتخار بالماضـي البعيد ( والزهو بالعز السالف لم يكن انتشاءً سلبياً بعهد مضسى، أو تغنياً وجدانياً بحقبة غبرت، فهذا الماضي البعيد لم يكن أبداً في

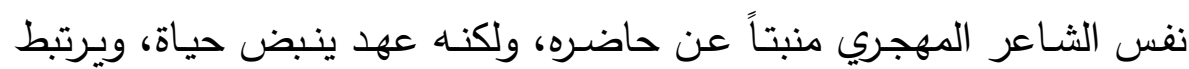
أوثق ارتباط بواقع العرب) (')

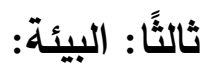
البيئة هـي: ( كل مـا يحيط بالإنسـان، أو يؤثر فيـه بطريق مباشـر أو غير

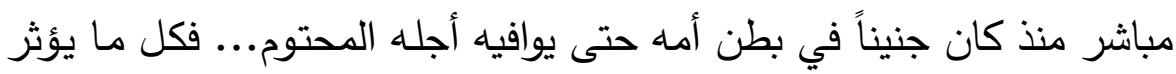

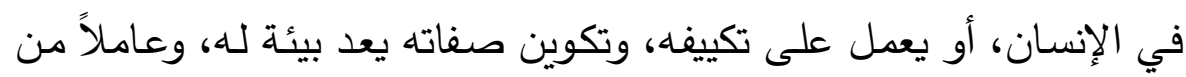

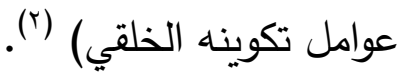
وللبيئة أثر قوي في تتمية الأخلاق الموروثة، والعمل على تزكيتها وتهذيبها، أو طمسها ومحوها. هذا وللبيئة بأنواعها: طبيعية واجتماعية وثقافية أثر فاعل على قيم الإنسان، فقد تغذيها وترقيها، أو تضعفها وتقنيها.

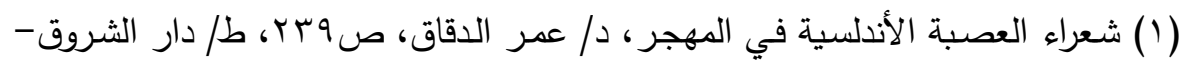

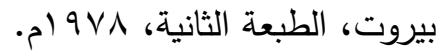

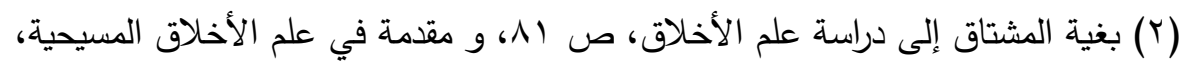

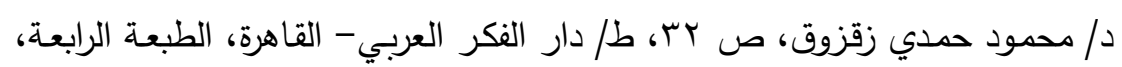


أثر التصوير البياني والتحسين البديعي فِ أداء معنى الصفح هٍُ الشعر المهجري: القروي

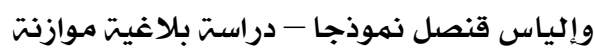

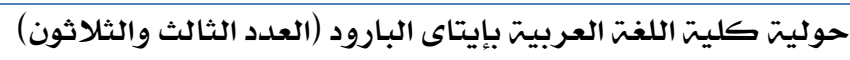

قال تعالى:

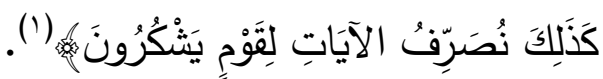

وللبيئة الطبيعية والاجتماعية التي عايشها شعراء المهجر الجنوبي في أوطانهم كيان وروح ومعنى أثر عظيم في نفوسهم، طبع نفسياتهم بطابع عفوي فطري

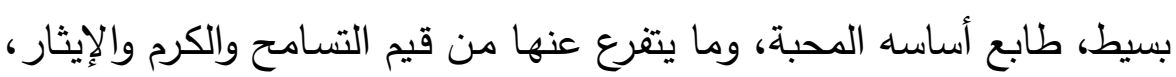
والعدل والرحمة، والوفاء والعفة....الخ.

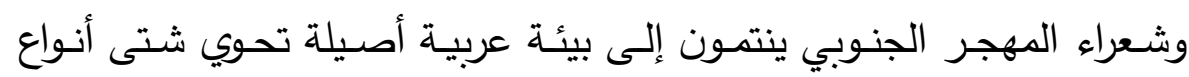
الثقافات، وهي مهبط الوحي لكثير من الديانات، تضم مختلف الطوائف والفرق

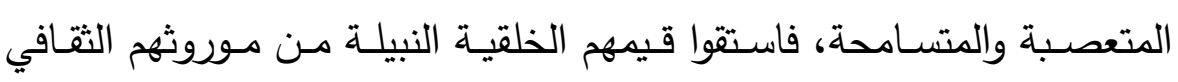
والديني. فالموروث الثقافي والديني الذي تشربه الثـعراء في الوطن من تعاليم الدين

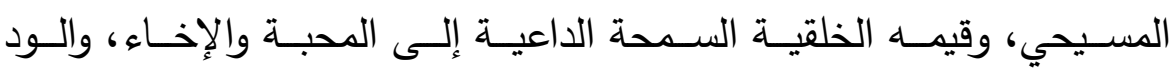
والتعاطف، والرحمـة والعدل كان زادهم الذي يتزودون بـ في مهجرهم النائي، حتى صـار تأثرهم بتعـاليم المسيحية السـحة خاصــة مـن خصـائص شعرهم المهجري.

والقصيدتين: تسبيحة الحب للقروي، وترنيمـة الصفح لإلياس قنصل - محل التحليل - يجسدا معاني الحب والتسامح والود والوفاء التي نادت بها الديانة

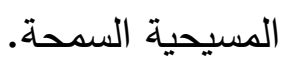
هذا ولا يخفي أثر الثقافة الإسـلامية التي استقاها شعراء المهجر الجنوبي من

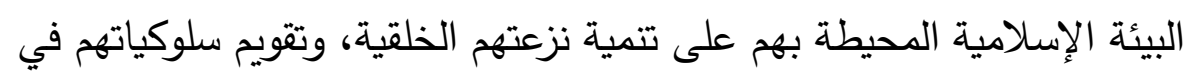

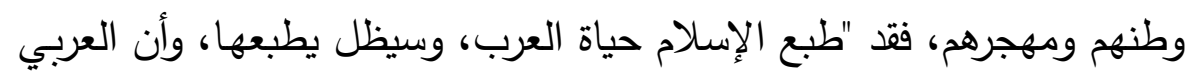

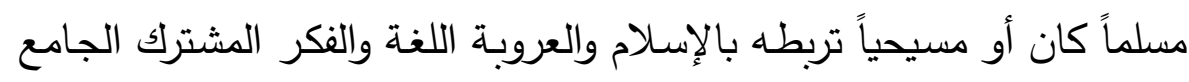
والأخلاق، وقد وحد الإسلام الثقافة التي تربط العناصر المختلفة التي استظلت 
أثر التصوير البياني والتحسين البديعي هِّ أداء معنى الصفح هٍِ الشعر المهجري: القروي

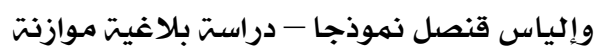

حوليت كليت اللغت العربيت بإيتاى البارود (العدد الثالث والثلاثون)

بظله، ولو كانوا غير مسلمين ديناً"(').

وبذلك أتيح لشعراء المهجر الجنوبي خبرات وموروثات ثقافية دينية اكتسبوها من بيئتهم العربية الأصيلة خضبت شاعربتهم وأذكتها، وقومت نفوسهم بانتهاج السلوك الخلقي القويم، والحث على التحلي بمكارم الأخلاق التي دعت إليها الأديان السماوية.

رابعًا: طلب حسن الأكر:

كانت الرغبـة في خلود الذكر وبقائهـ باعثاً مـن البواعث التي حدت بشعراء المهجر الجنوبي إلى المحافظة على كريم أخلاقهم، والتمسك بجليل فضائلهم. لقد فروا إلى مغتربهم محساولين تحقيق الذات وإعـاء شـأنها، ولكن أظلتهم وأحاطت بهم ظروف نفسية واقتصادية سيئة وحالف الفقر وسوء الحظ الكثير منهم، فلم يبق من سبيل يخلد الذكر، ويبقى الأثر عطراً سوى التمسك بحسن وهن

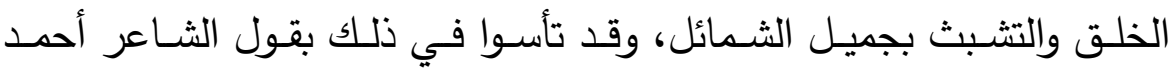

شوقي: (r)

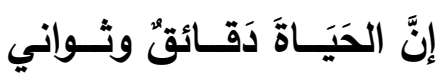

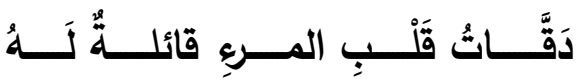

فالـذكْرُ للإنســانِ عمـرُ تَانِ

فارفِعْ لنفسِكَ بَعْدَ مَوْتَكِ ذِكْرَهَا

فالثـاعر القروي يوقن بأن للحياة نهايـة محتومسة ومصير معلوم فليس سوى

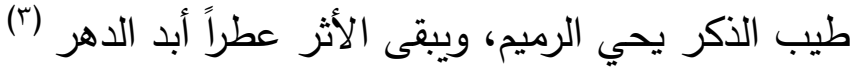
لا عِطرَ في الأرضِ يَقْوي على نَتَانَةِ قَبْرِكْ

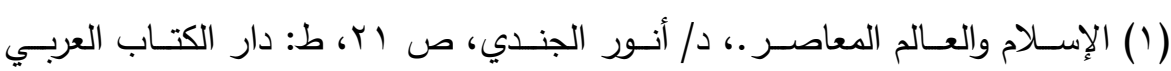

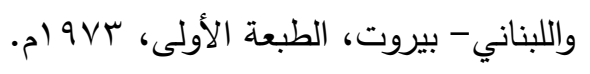

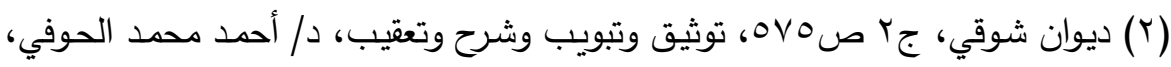

ط/ دار نهضة مصر الفجالة-القاهرة، بدون تاريخ.

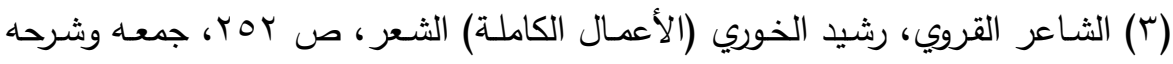

وقدم له، مكتب التدقيق اللغوي طا جروس برس - طرابلس - لبنان.، بدون تاريخ. 
أثر التصوير البياني والتحسين البديعي فِ أداء معنى الصفح هٍُ الشعر المهجري: القروي

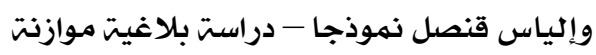

حوليت كليت اللغت العربيت بإيتاى البارود (العدد الثالث والثلاثون)

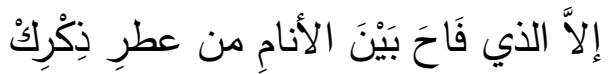

فقد التقت شعراء المهجر الجنوبي إلى هذا الباعث الخلقي القويم، فوضـوه نصب أعينهم، وكـان إمـامهم وهاديهم، وحافزهم القوي على التمسك بقيمهح

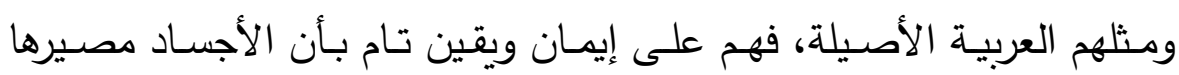

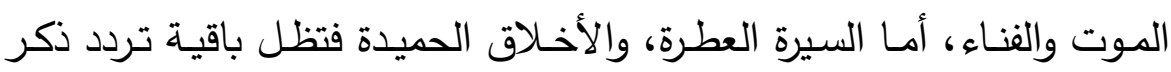
صاحبها، وتحيي أثره على امتداد الدهور وطول الآماد. بين يدي الشاعرين:

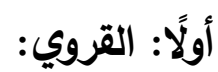

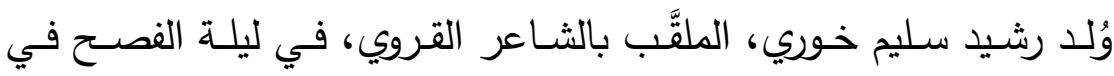

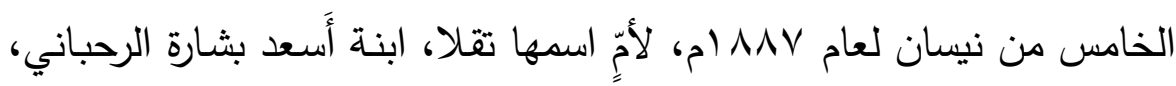
وأبوه سليم بن طنوس بن منصور بن حنا الخوري، وجَدُّه طنوس كان طبيبًا، ونقل بخطه عن ابن سينا عدة كتب في الطب. وكان مسقط رأس القروي بقرية البربارة على هضبة مشرفة على البحر الأبيض، بين مدينتي جبيل والبترون من جبل لبنان. ومسن أشقائه: قيصـر ، الثـاعر المـدني، الذي كـان يصـغر القروي بـأربع سـنوات ونصـف، وفيكتوريـا التـي تزوجـت في الخامسـة عشـرة مـن عمرهـا وهاجرت وزوجها إلى أمريكا(')، ولم يتزوج القروي طيلة حياته؛ لأنه كان في تروني

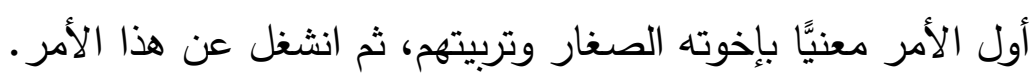
صفات القروي الخلُقية والثخصية: من الصفات البارزة للقروي ما يلي:

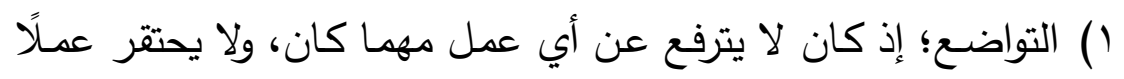

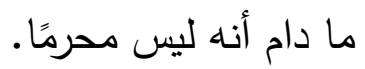

(1) ينظر : ديوان القروي، الأعمال الكاملة، ص 9- با. 
أثر التصوير البياني والتحسين البديعي فِ أداء معنى الصفح فِّ الشعر المهجري: القروي

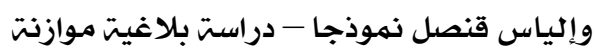

حوليت كليت اللغت العربيت بإيتاى البارود (العدد الثالث والثلاثون)

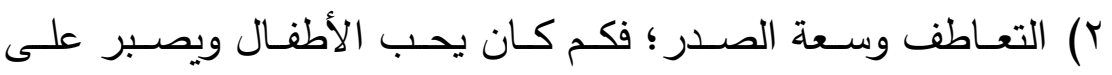

مجالستهم، ولا يزعجه ضجيجهم حتى لو كان يطالع أو يكتب.

r) شديد التأثر بالجمال؛ فيثده كل شيء جميل، ولا يستطيع مقاومته.

؟) الموضوعية والحيادية؛ فقد كان يحكم بالحق حتى لو لعدوه اللدود.

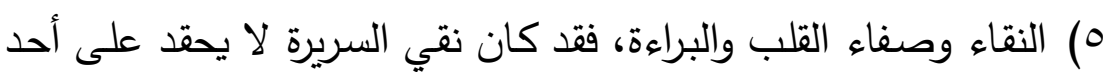

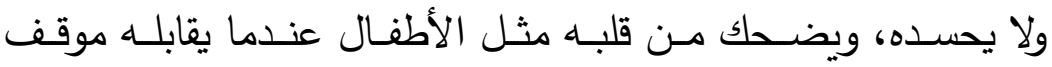

مضحك، ويبكي لأبسط الأمور التي يمكن أن تُبكِي.

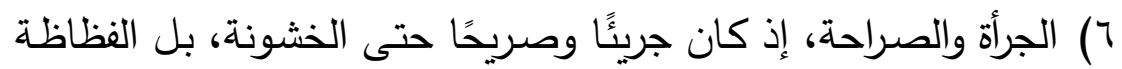

أحيانًا.

إيمان القروي:

كان القروي مسيحي الديانة، مؤمنًا شديد التعلق بالله والتمسك به، وكان يعتقد أن

الحسنات من الله والمساوئ من نفسه.

وكان القروي يستقوي بذكر الخالق عَلَى نزغات نفسه ويطمئن إلى رضـاه عنه،

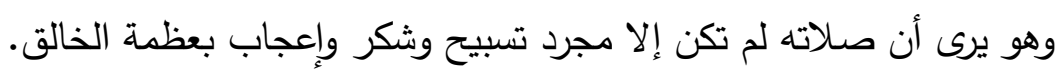

\section{شفف القروي بالطبيعة:}

للطبيعة سحرها الخاص في نفس الإنسان، خاصة في البلاد التي نثأ فيها القروي مما كان لها الأثر الكبير في شعره.

أصدقاؤه وأعداؤه:

كان للقروي أعداء كثيرون، لكنه لم يحمل لأي أحد ضـغينة أو حقدًا أو حسدًا طيلة حياته؛ لأنـه كان شديد التسامح كثير الصفح، وقصيدته: تسبيحة الحب توضح لنا ذلك وتؤكده .

وفات القروي:

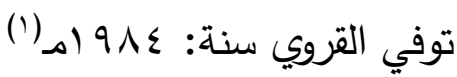

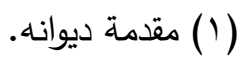


أثر التصوير البياني والتحسين البديعي هِّ أداء معنى الصفح هٍِ الشعر المهجري: القروي

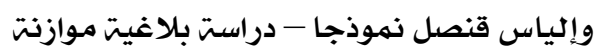

حوليت كليت اللغت العربيت بإيتاى البارود (العدد الثالث والثلاثون)

ثانيًا: إلياس قنصل

هو إليـاس ميخائيل قنصـل، عربـي الأصـل، سـوري الموطن، أرجنتيني

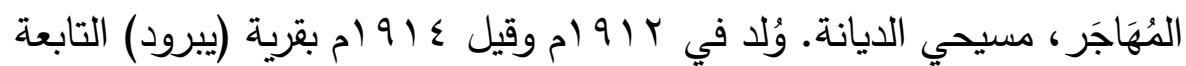
لقرى جبل قلمون بسوريا.

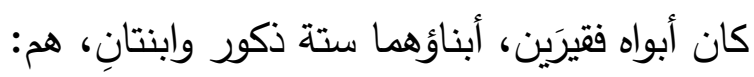
1- - إنجلاء؛ وهي أكبر إخوة إلياس.

r- إلياس؛ الذي تلقَّى بمدرسـة يبرود سنوات المرحلـة الابتدائية، ثم هاجر مع أبيه إلى الأرجنتين.

r- زكي؛ وهو الثاعر المعروف بأشعاره الرائقة. ع - حَنَّا، الثاعر الذي ضونداعت كل قصائده بعد وفاته. 0 - - جنفياف؛ التي تزوجت في يبرود. 7- يوسـف؛ لـه قصـائد منشـورة بمجلـة المواهـب، والجريـدة السـورية

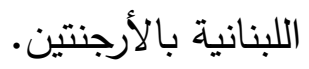

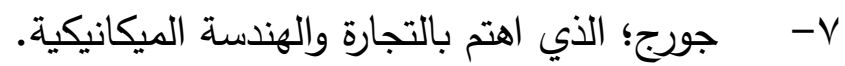

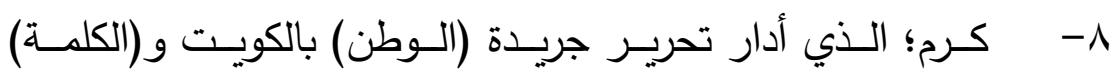
بدمشق، وكتب كثيرًا بصحف الخليج، وأذاعت إذاعة لندن بعضًا

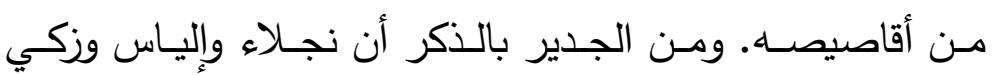

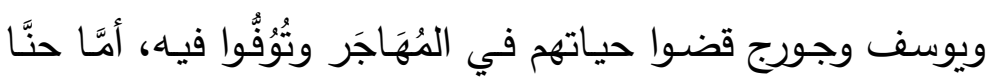
وجنفياف وكرم فمكثا وقضوا حياتهم بأرض الوطن ('). كان والد إلياس يعمل في نَنْج شَعر المـاعز، ثم سافر للبرازيل في سنة

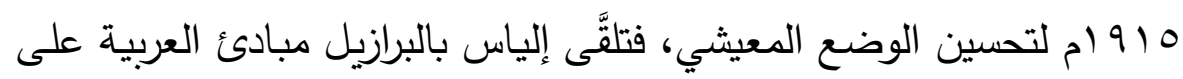

(1) ينظر : إلياس قنصل حياته وشعره، أيمن عثمان عبد العليم محمد، رسالة ماجستير

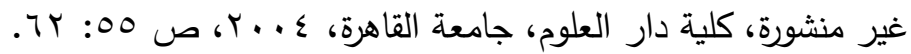


أثر التصوير البياني والتحسين البديعي هِّ أداء معنى الصفح هٍِ الشعر المهجري: القروي

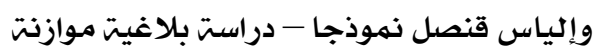

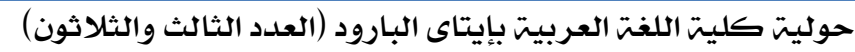

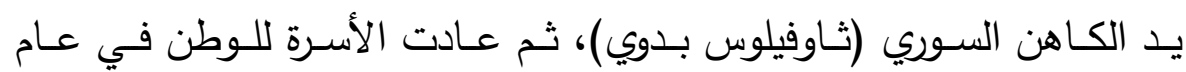

. 9 ام، والتحق إلياس بمدرسة يبرود ونبغ فيها (').

هماته وبدايات دواوينه الأولىى:

سـافر إلياس ووالده مرة أخرى إلى البرازيل في عام هبو امه، وبعد فترة

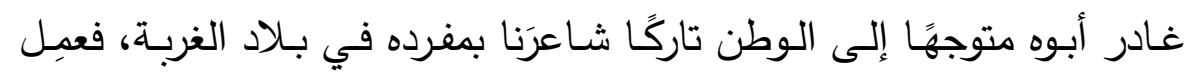
إلياس بمحل تجاري لأكثر من سنتين، ثم عاد أبوه إلى البرازيل برفقة زكي.

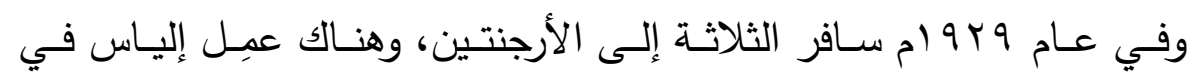

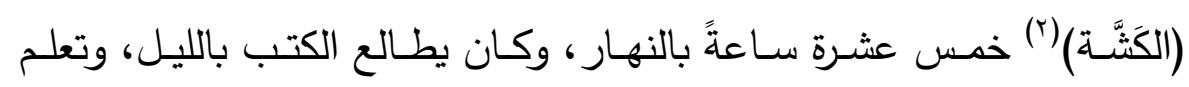

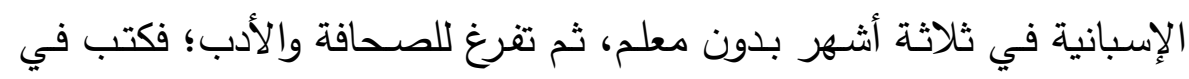

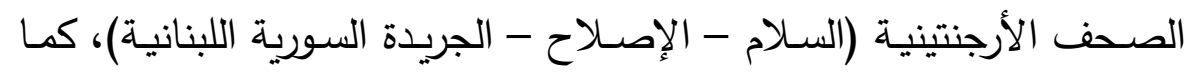
كان يراسل بعضًا من صحف الوطن مثل الرسالة والمقتطَف، وترأس تحرير

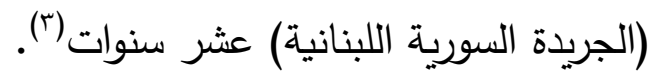
في هذه الفترة أصدر دواوينه الأولى:

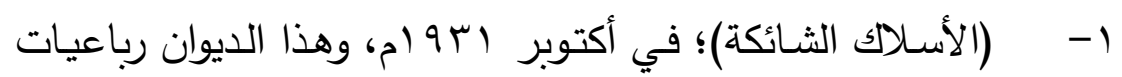

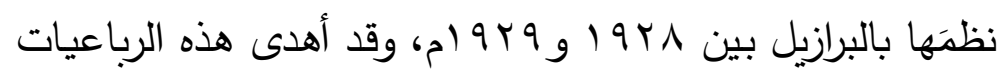

$$
\text { إلى رجال الغد. }
$$

r- في العام نفسه أصدر (العبرات الملتهبة)، الذي أهداه لأمه. r- - كان ديوانـه الثالث بعنوان (على مذبح الوطنيـة)، وكتب مقدمتَه الأستاذ موسى يوسف عزيزة صاحب (الجريدة السورية اللبنانية).

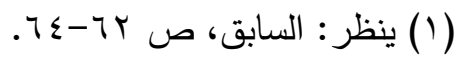

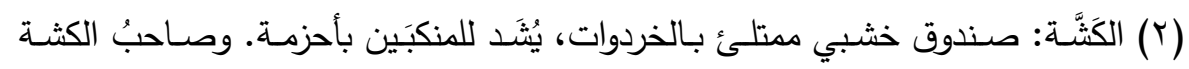
يجول في الثوارع ليبيع ما بها.

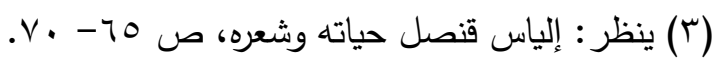


أثر التصوير البياني والتحسين البديعي هِّ أداء معنى الصفح هٍِ الشعر المهجري: القروي وإلياس قنصل نموذجا - دراست بلاغيت موازنت

حوليت كليت اللغت العربيت بإيتاى البارود (العدد الثالث والثثلاثون)

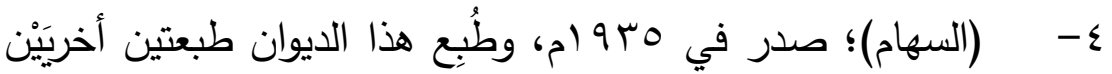

في العام نفسه، وكان أحبَّ دواوين إلياس إلى قلبه(').

آرلؤه في الثعر:

كانت لإلياس آراؤه الخاصـة في الثعر والثـعراء التي تميز بها؛ إذ رأى

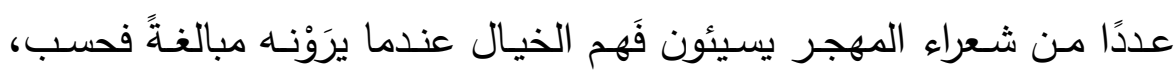
فدعاهم للتمييز بين الخيال والمبالغة. ورأى أن عقم الموهبة قد يطيح بصاحبه في واد عميق ويجعله يأتي بتشبيهات زائفة.

كمـا رأى أن نقل الواقع والتصـوير الفوتوغرافي لا علاقـة لـه بمهمة الثـاعر، فمهمة الثاعر عنده أن يتغلغل إلى صميم الحياة في الثيء الذي يصفه لنا، فيطلع علينا بصورة تجعل نظرتنا إلى هذا الثيء أجمل وأعمق (؟). وفاته: في أواخر عام • 91 ام شعر إلياس بآلام شديدة في يده، وامتدت الآلام إلى رجله وأصابه شيء من الشلل، وأرسل إلى أخيه كرم آخر رسالة إليه في

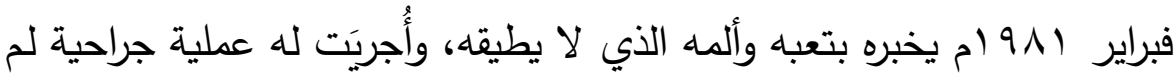

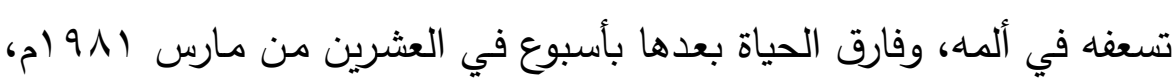
عن عمر يناهز التاسعة والتسعين(ّ).

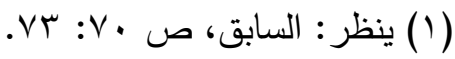

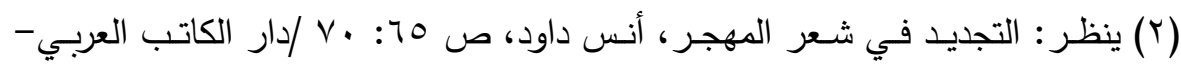

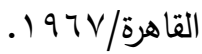

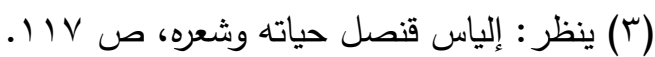


أثر التصوير البياني والتحسين البديعي ِِّْ أداء معنى الصفح ِِّ الشعر المهجري: القروي

وإلياس قنصل نموذجا - دراست بلاغيتة موازنت

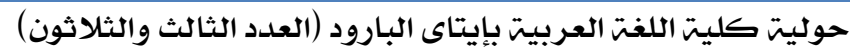

الإبمث الأول

أثر التصوير البياني في أداء همنى الصفح بين القُروي وقنصل

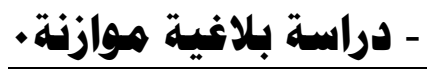

هفهوم الصورة البيانية:

أولًا: مفهوم الصورة البيانية عند القدماءئه

لـم يستطع القدماء النهوض بمصسطلح الصـورة البيانية إلى المجـال الاصـطلاحي، ولـم يخرجـوا عن مـلولها اللغـوي، ولـم يتبلـور عنـدهم بُعْدها النقدي(')، إلا أن هنالك كثيرًا من الإثارات والمحاولات الساعية لتحديد مفهوم

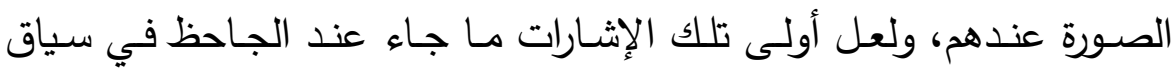
تعريفـه الثـعر بقولـه: " إنمـا الثـعر صــاعة، وضـرب مـن النسـيج، وجنس إلس من التصوير"( (؟).

ومن تلك الإثـارات ما جاء عند قدامة بن جعفر ؛ فقد رأى أن الصورة تمثل

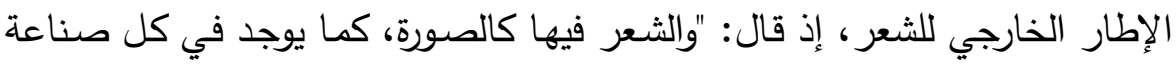
من أنه لا بدّ فيها من شيء موضوع، يقبل تأثير الصور منها..."(").

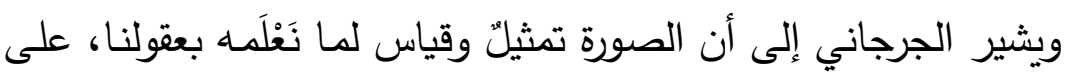

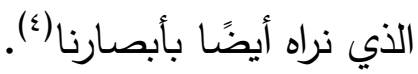

( (1) ينظر : نظريـة النقد العربي - رؤيسة قرآنية معاصرة، محمد حسين علي، ص ب ז،دار المؤرخ العربي - بيروت - لبنان.

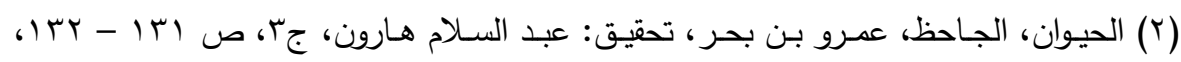

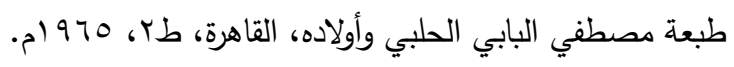

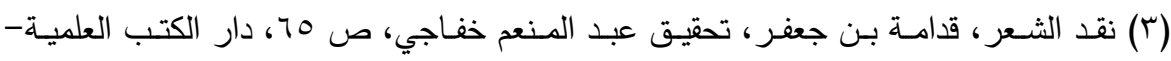
بيروت، لبنان.

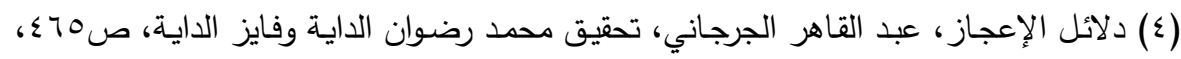

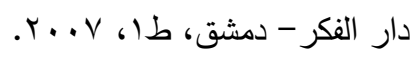


أثر التصوير البياني والتحسين البديعي ِِّْ أداء معنى الصفح ِِّ الشعر المهجري: القروي

وإلياس قنصل نموذجا - دراست بلاغيتة موازنت

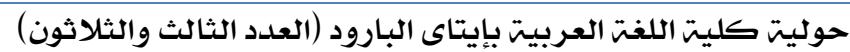

ويرى حازم القرطاجني أن الصورة بمعنى الاستعارة الذهنية لمدرك حسي في

الذهن غير موجود في الإدراك المباشر (1).

\section{ثانيًا: مفهوم الصورة البيانية عند المحدثين:}

أما مفهوم الصورة البيانية عند المحدثين فقد بدا عندهم متأرجحًا، وقد

تخلل بعض تعريفاتهم الغموض وعدم التحديد؛ إذ استعملوا كثيرًا من الكلمات، كالإيحاء والألوان والحركة والحس وغيرها، لتفسير معنى الصسورة، وظلوا بذلك يحومون حول مصطلح الصورة، ولم يحددوه تحديدًا علميَّا دقيقًا (r). ومسن تعريفات المحدثين للصـورة الفنيـة أنها "حركة متصـلة في قلب العمل الأدبي، نتبصـر بها في دوائره ومحاوره ومنعطفاته، ونتتقل بها داخل العمل الأدبي من مستوى تعبيري إلى مستوى تعبيري آخر حتى يتكامل البناء الأدبي كائناً عضوياً حياً" (r)" بينمـا يرتبط مصسلح الصـورة الفنية عند صـلاح فضـل بمـا هو مدرك بـالحواس، بصـرية أو سـمعية، أو لمسـية أو ذوقيـة، ويحـرك خيـال المتلقي باسـتـعائه معلومـات ترجـع إلى الذاكرة، فتثيـر تصـوره الحسـي للأشـياء، وأن الأدوات البلاغية من استعارة وتشبيه وغيرهما هي إلا آليات الصورة(ء). ويحدد جابر عصفور مفهوم الصسورة بقوله: "إن الصسورة هي الوسيط الأساسـي الذي يستكثف بـه الثـاعر تجربته، ويتفهها كي يمنحها المعنى والنظام، وليس ثمة ثنائية بين معنى وصسورة أو مجاز وحقيقة، أو رغبة في

(1) ينظر : منهاج البلغاء وسراج الأدباء، حازم القرطاجني، تحقيق محمد الحبيب خوجة، ص1/19 -1، دار الغرب الإسلامي، طس، بدون تاريخ.

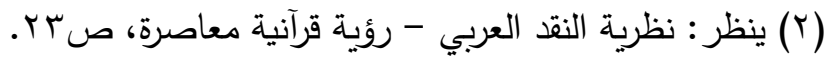

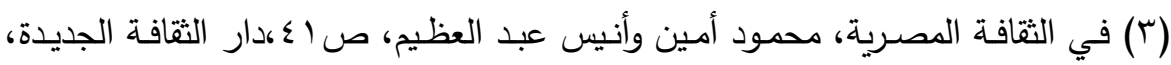
طا، بدون تاريخ.

(ع) ينظر : علم الأسلوب، صلاح فضل، ص ابس، دار الشروق، القاهرة، طا، 1991 19 
أثر التصوير البياني والتحسين البديعي هِّ أداء معنى الصفح مِّ الشعر المهجري: القروي

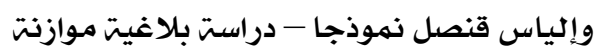

حوليت كليت اللغت العربيت بإيتاى البارود (العدد الثالث والثلاثون)

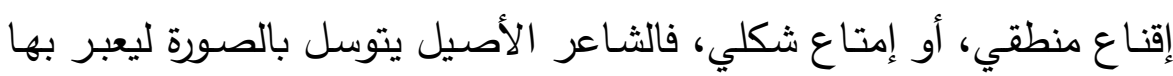

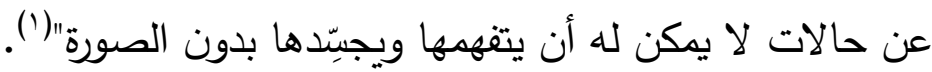

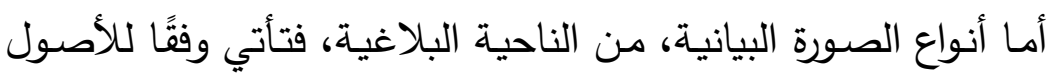

$$
\text { التي تُننى عليها؛ وهي (r): }
$$

- الصورة التشبيهية: وهي: الدلالـة على مشـاركة أمر لأمر آخر في

معنى بحيث لا يكون على وجه الاستعارة التحقيقية

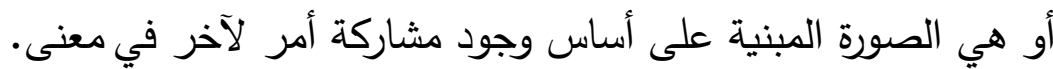

- الصورة الاستعارية: وهي الصورة المبنية على أسـاس تعليق العبارة

على غير ما وُضعت له في أصل اللغة، على جهة النقل للإبانة.

- الصورة المجازية: وهي الصورة التي تعتمد على التعبير المجازي في

التصـوير، والمجاز طريقـة خاصـة في التعبير، مثيرة لخيـال المتلقي، حيث يُخرج المتلقي عن المـألوف، وينشط ذهنه، ليدرك العلاقات الجديدة في ذلك

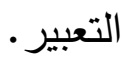

- الصـورة الكنائية: وهي: الإتيان بلفظ أريدـ بـه لازم معنـاه مـع جواز

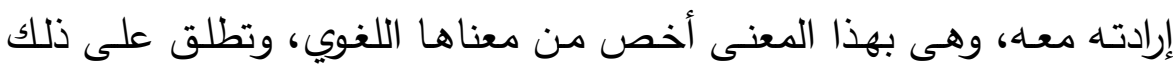

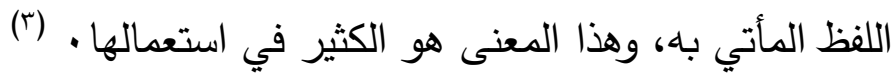
أو هي الصورة المبنية على أساس وجود صورة متطورة مباشرة، وصورة متخيلة مرتبطة معها، تُبنيان بطريقة منسجمة لا تمنع من صحة تصور الاثنتين، إلا

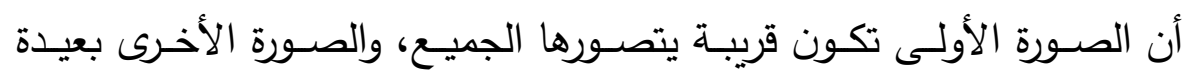

(1) الصـورة الفنيـة في التراث النقدي والبلاغي عند العرب، جابر عصفور ، ص سمب،

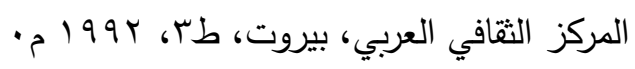

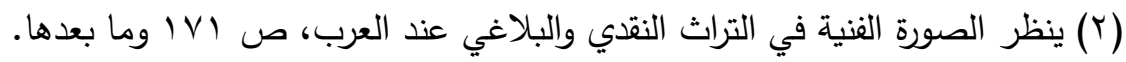

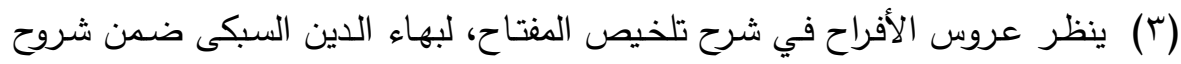

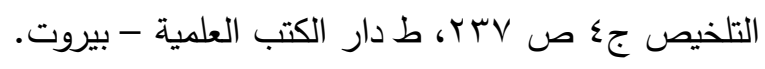


أثر التصوير البياني والتحسين البديعي هِّ أداء معنى الصفح هٍِ الشعر المهجري: القروي

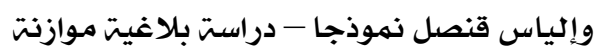

حوليت كليت اللغت العربيت بإيتاى البارود (العدد الثالث والثلاثون)

مقصودة، لا يتصورها إلا المتمكن من أساليب اللغة وطرق تعبيرها.

وقد يكون في تعريف جابر عصفور ما يحيط بمفهوم الصور الفنية من

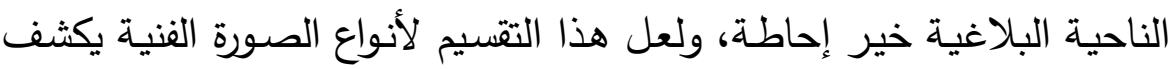
جوانب كثيرة من الدلالات التي تؤديها، بما تثتمل عليه من تشبيه أو استعارة أو مجاز أو كنايـة، أو دمـج بين أكثر من دلالـة مسن الدلالات السـابقة، وقد بنيـت هذه الدراسـة في هذا المبحث (أثر التصـوير البياني في أداء معنى الصفح في الثعر المهجري ) على هذا الأساس.

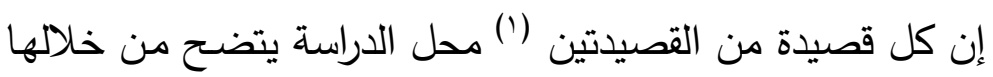

أثر التصـوير البياني في مـؤزرة الثـاعر في استخراج المعنى مـن أعماقـه وإبرازه، وتقريبه للأذهان

وقد اختلفا الثاعران في استخدامهما للصورة البيانية كلٍ بحسب قصده وغرضه

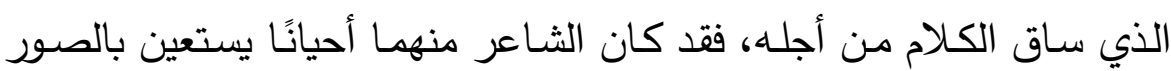
البيانية المختلفة بأن يأتي بالتشبيه والمجاز والاستعارة والكناية في المقطوعة

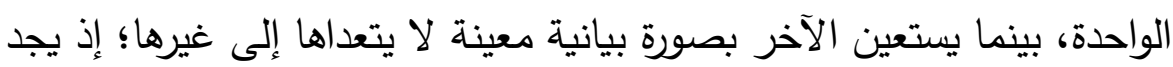
في تلك الصورة مبتغاه ومقصده. فمثلً في مقطوعة القروي الأولى نجده قد اعتمد على التصوير الاستعاري فقط ولم يستعن بـأي مـن الصـور البيانيـة الأخرى في الكثف عن حبـه الكبير

(1) القصيدة الأولى للقروي، وتسمى القصيدة بتسبيحة الحب وعدد مقطوعاتها: خمس وعشرون مقطوعة، ينظر : ديوان القروي، الأعمال الكاملة الثعر • والقصيدة الثانية لقنصل، وتسمى بترنيمة الصفح، وعدد مقطوعاتها:خمس وعشرون مقطوعة، هذه القصيدة قد عارض بها قنصل قصيدة القروي: تسبيحة الحب، ينظر ديوان إلياس قنصل: الأسلاك الثائكة.

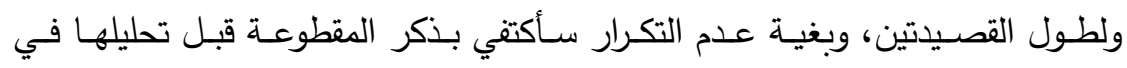
موضعها ولم أذكر نص القصيدتين بشكل كامل مستقل عن التحليل . 
أثر التصوير البياني والتحسين البديعي فِ أداء معنى الصفح هٍُ الشعر المهجري: القروي

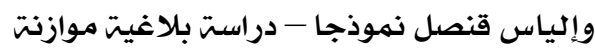

حوليت كليت اللغت العربيت بإيتاى البارود (العدد الثالث والثثلاثون)

وصفحه الثـديد، ذلك الثـعور القوي الذي يستطيع أن يمحو بـه أقوى أنواع البغض وأعتى أشكال الكراهية؛ إذ يقول:

" سأجرُفُ بغضكم بالحبّ جرفا وأنسفُ غيظكم بالحلم نسفال

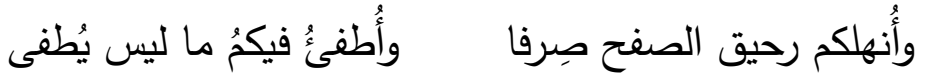

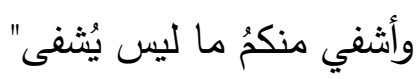

يُلاحظ التصوير الاستعاري في قوله "سأجرف بغضكم بالحب جرفا"، إذ شبه

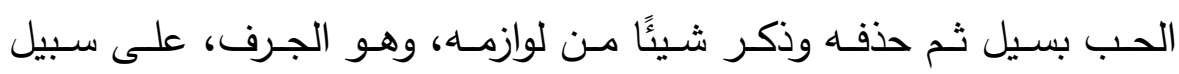

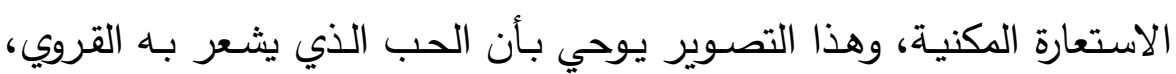

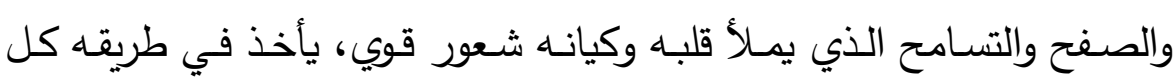
شعور سيئ مؤذٍ من بغض وكراهية وغيرهما، ليمحو ذلك محوًا لا بقاء بعده،

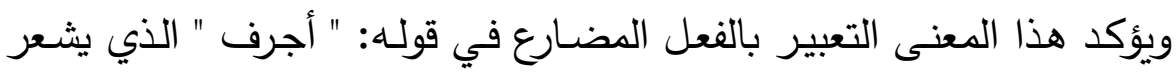
بأن القروي سيستمر في هذا العمل ولن ييأس أبدا من تحقيقه، وكذلك التعبير بالمفعول المطلق في قوله: "جرفا" الذي يزيد المعنى تأكيدًا فوق تأكيد من أن شعور الحب سيمحو كل بغض أو كراهية من نفوس الأعداء.

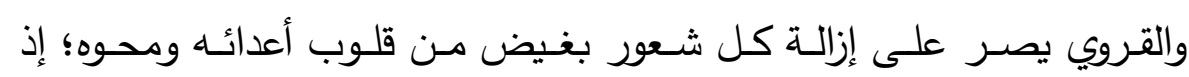
يستخدم الوسائل المختلفة لتحقيق ذلك، ففي القول السابق كانت وسيلته الحب، وها هو يطالعنا بوسيلة أخرى يزيل بها كل حقد وبغض من نفوس الأعداء،

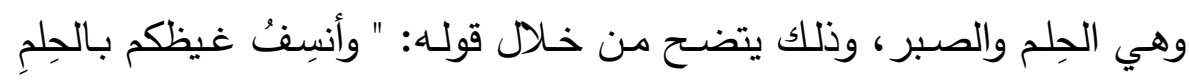

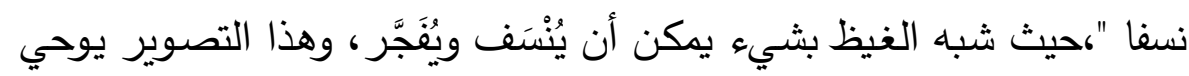

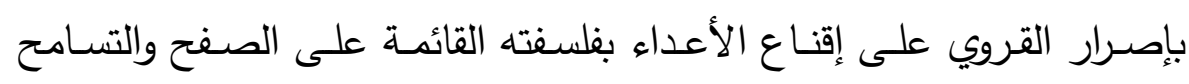
والتغافل عن بعض الأخطاء، وليس هذا فحسب بل يؤكد إيمانه الثديد بفكره وطريقته؛ إذ يرى في نفسـ القدرة على تغيير قلوب أعدائه الحاقدة المبغضـة إلى قلوب مُحِبة هادئة مطمئنة، تتسم بالحلم والصفح. 
أثر التصوير البياني والتحسين البديعي هِّ أداء معنى الصفح هٍِ الشعر المهجري: القروي

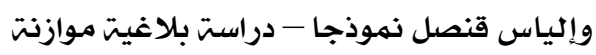

حوليت كليت اللغت العربيت بإيتاى البارود (العدد الثالث والثثلاثون)

ولإيمان القروي بالتصوير الاستعاري وإدراكه لقيمته الكبرى نجده قد لجأ

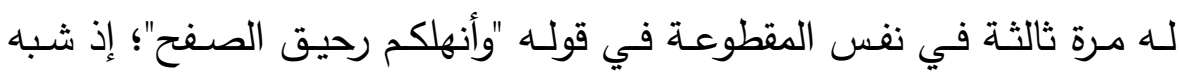
الصفح بالماء الذي يُنْهَلَ، والزهر الذي يُمْتص رحيقه، ثم حذفهما وذكر شيئًا من لوازمهما، وهو النهل والرحيق على سبيل الاستعارة المكنية، وهذه الاستعارة

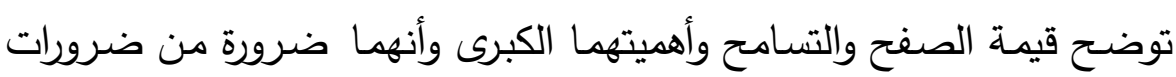

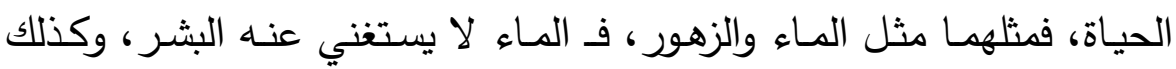
الزهر الذي يطف الأجواء وينقي الهواء، ويُنْخِل بعبيره على النفوس الراحة والبهجة، فكذلك الصفح من المهم أن يكون موجود بين البشر . فـ"الاستعارة أصـدق أداة تجعـل القـارئ يحس بـالمعنى أكمـل إحســس وأوفـاه، وتصـور المنظر للعين وتتقل الصـوت لـلأذن وتجعل الأمـر معنويـا

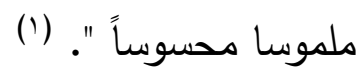
وقد آزر التصسوير في مقطوعة القروي حرف الهمس ( الحساء ) الذي جاء متكررًا في تعبيرات المقطوعة ( الحب- الحلم - رحيق ) في الإشعار بمعنى الراحة والسكينة والهدوء. وقد اتخذ إلياس قنصل كذلك من التصوير مطية تصل بنا معه إلى غور المعنى الذي يقصده في مقطوعته الأولى، وهو: ثقته الثديدة بنفسه واعتزازه

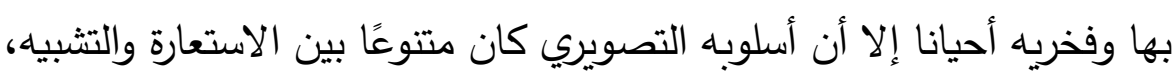
حيث يقول:

$$
\begin{aligned}
& \text { " رَصَفْتُ لَكُمْ سَبِيِلَ الْمَجْدِ رَصْفَا } \\
& \text { وَلَزمْ أَكْتُبْ لِغَيْرِ الحَقِّ حَرْفَا } \\
& \text { فَرُحْنُمْ تَقْطِفْونَ الْفَخْرَ قَطْفَا }
\end{aligned}
$$

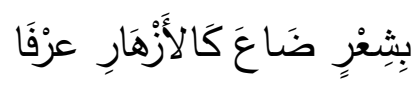

(1) من بلاغة القرآن، لأحمد أحمد بدوي، ص VIV Vار نهضة مصر ،بدون تاريخ. 
أثر التصوير البياني والتحسين البديعي فِ أداء معنى الصفح هٍُ الشعر المهجري: القروي

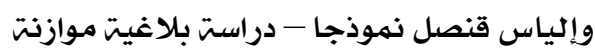

حوليت كليت اللغت العربيت بإيتاى البارود (العدد الثالث والثلاثون)

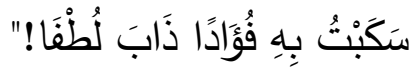

فها هو يستخدم التصوير الاستعاري في قوله " رَصَفْتُ لَكُمْ سبيل المجد"، إذ

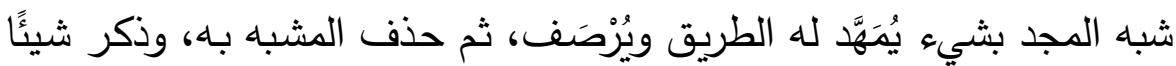

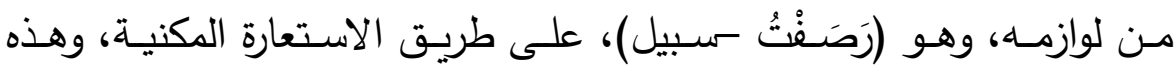
الاستعارة تجعل المجد لـه طريقًا يجب على من يطلبه أن يعبِّّ هذا الطريق

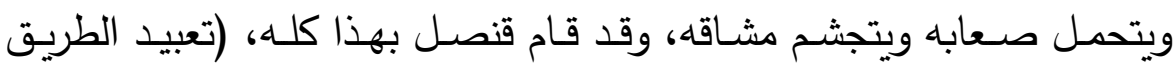
وتذليله)، من أجل قومه فهو لم يجعلهم يتكبدون المشاق ويتحملون الصعاب، وله ولهابه حيث أنه قد ذلل لهم الطريق بعد رصفه. ويلجأ قنصل مرة أخرى إلى التصـوير الاستعاري في قوله:" فرُحْتُم تقطفون الفخر قطفا بثـعر ضـاع كالأزهـار عرفـا " إذ شبه الفخر بزهور تُعُطَف، ثم حذف المشبه بـه وذكر شينًا مـن لوازمـه وهو القطف على سبيل الاستعارة المكنية، وهذه الاستعارة توحي باستمتاع أعداء الشاعر بالمجد الذي جلبه لهم

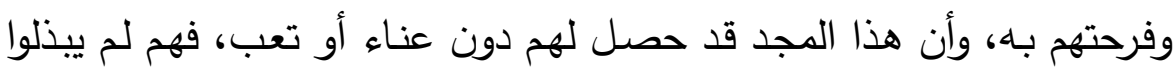

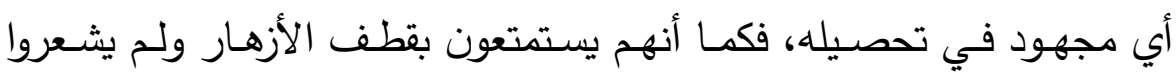
بمجهود في قطفها، كذلك استمتعوا بالفخر الذي جلبه لهم الثاعر . وقد حقت الاستعارة في المقطوعة الإيجاز والاختصسار في العبارة مع القدرة على تركيز الفائدة، وعدم الإخلال بالمعنى المراد؛ إذ إنها تعطي (الكثير من المعاني باليسير من اللفظ حتى تخرج من الصدفة الواحدة عدة من الدرر، الصن وتجني من الغصن الواحد أنواعاً من الثر ) ('). وفي نفس المقطوعة يستعين قنصل بالتشبيه ليؤازره في إبراز فكرته، حيث تتعانق الصورة التشبيهية مع الصورة الاستعارية في قوله السابق؛ إذ شبه شعره

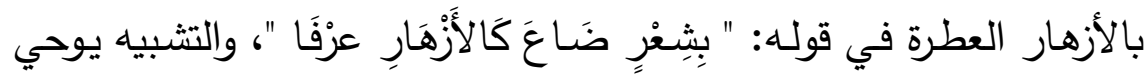

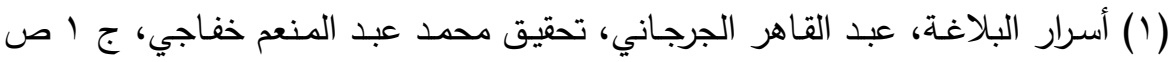


أثر التصوير البياني والتحسين البديعي هِّ أداء معنى الصفح مِّ الشعر المهجري: القروي

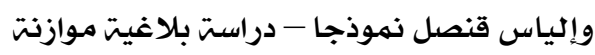

حوليت كليت اللغت العربيت بإيتاى البارود (العدد الثالث والثلاثون)

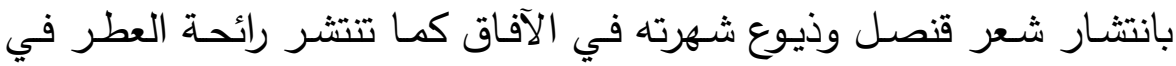
الأجواء بفضل الهواء، وأن هذا الشعر شعر عظيم الأثر طيب المغزى، وأكد هذا المعنى بقوله " عزَفًَا ". وألفاظ البيت وتعبيراته جعلت التشبيه ( يجري في تدفق وانسياب كماء البحر

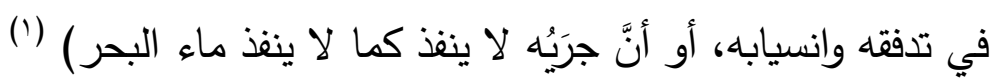
ويعود قنصل إلى التصسوير الاستعاري مرة ثانية في نفس المقطوعة في

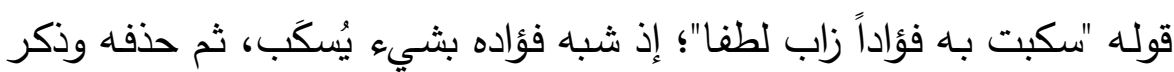
شينًا مـن لوازمـها وهو السكب على سبيل الاستعارة المكنيـة، وهذا التصـوير يوحي بشدة تأثير شعر قنصل في سامعيه وقارئيه، فما سمعه أو قرأه أحد إلا وذاب قلبه، فقد كان شعرًا صسادقًا من أعماق قلبه، وقد امتزجت كل كلمة منـه بكل قطرة من دمه، وأن، شعره لم يكن منه سهلًا يسيرًا بل إنه قد كلفه الكثير من الوقت والجهد.

ونذهب إلى المقطوعـة الثانيـة للشـاعرين ليتضـح من خلالهمـا مـا يحملـه

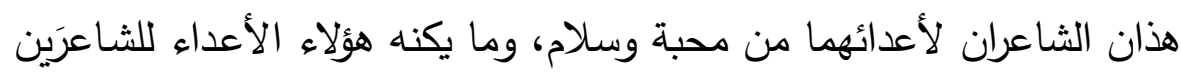
مـن عـداوة وبغـض، فنجـد القـروي قـد تتـوع تعبيـره التصـويري بـين التشـبيه والاستعارة والكناية؛ إذ يقول: " بَني أُمي الجياع إلى خِصامي ألا ذقتم يسيرًا من طعامي

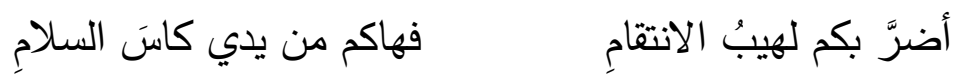
تفيض محبةً وتسيلُ عَطفا"

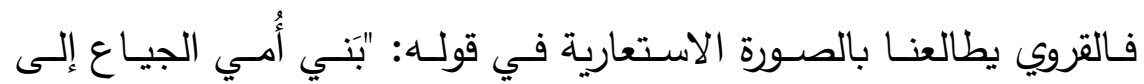

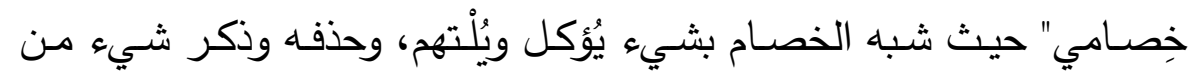
لوازمـه وهو الجوع الدافع إلى الأكل والالتهام على سبيل الاستعارة المكنيـة،

(1) البلاغة وقضايا المشترك اللفظى، د./ عبدالواحد حسن الثيخ، صده، مؤسسة شباب

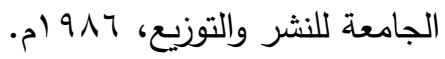


أثر التصوير البياني والتحسين البديعي هِّ أداء معنى الصفح هٍِ الشعر المهجري: القروي

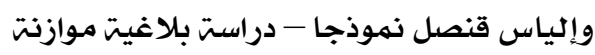

حوليت كليت اللغت العربيت بإيتاى البارود (العدد الثالث والثلاثون)

والتصوير يوحي بتحفزهم ضده وتأهبهم المستمر واستعدادهم التام لمهاجمته وخصامه، فهم يتحينون الفرصـة لذلك ، كما يشعر التصوير بأن الخصام هو لهو هون غذاؤهم الذي يتغذون عليه، وقوتهم الذي يقتاتون بـه وليس هذا فحسب، بل يستمتعون بـه، مما يوحي بكراهيتهم الشديدة للقروي، ويبرز حدتَهم وعداءهم

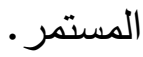

وتتضح الصورة الكنائية في قوله "ألا ذقتم يسيرًا من طعامي"، فقد كنى بهذا القول عن عطائه وخيره الذي طالما غرق فيه أعداؤه، وهذه الكناية كناية عن صفة، وقد عاون الصورة الكنائية أسلوب الاستفهام الذي جاء بغرض التوبيخ والتبكيت،و الكناية توحي بأن عطاء الثاعر لأعدائه كان عطاءً كبيرًا وليس عطاءً عاديا كأي عطاء. وقد آثر القروي في التعبير الكنائي لفظ " طعام " وذلك للإشعار بأهمية هذا العطاء وقيمته، وإيضـاح أثره الكبير في حيات أعدائه، فالطعام ضروري لبقاء الإنسان، كما أنه من المعروف أن الذي يأكل طعام أحد يصون عشرته

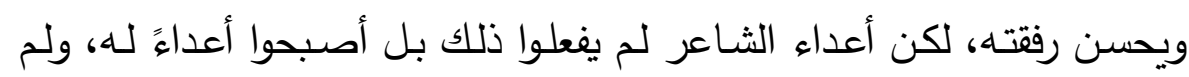
يؤثر فيهم هذا العطاء، مما يشعر بخستهم ودنوهم وقلة قيمتهم، فلم يؤثر فيهم

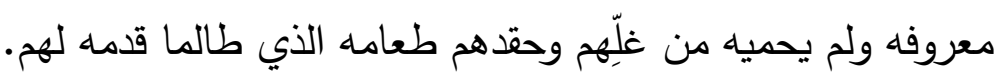
إن الكناية ( من أروع الفنون البيانية وأرقى الطرق البلاغية التي يعبر

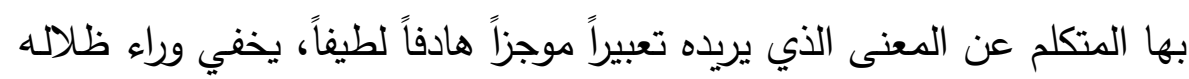
أهدافاً ولطائف يريدها ويقصدها) (') ويلجأ القروي إلى الصورة التشبيهية في قوله "أضرَّ بكم لهيبُ الانتقامٍ؛ إذ شبه ولهابه الانتقام باللهيب تشبيهًا بليغًا، والتشبيه يثعر بالغيظ والحنق والكراهية التي تملأ قلوب أعداء القروي، وأنها حارقة مهلكة لهم قبل غيرهم، كما يوحي هذا

(1) مـ الأسرار البيانيـة في الكنايـة القرآنيـة، حمـزة الدمرداش زغلول، ص جا، المطبعـة

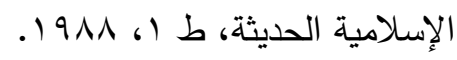


أثر التصوير البياني والتحسين البديعي فِ أداء معنى الصفح هٍُ الشعر المهجري: القروي

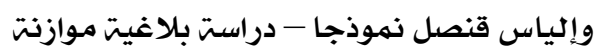

حوليت كليت اللغت العربيت بإيتاى البارود (العدد الثالث والثثلاثون)

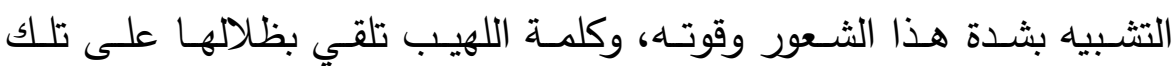
المشاعر السيئة وتصورها وكأنها نار تستعر في القلوب وتأكل كل من حولها. وتكمن روعة التشبيه هنا في أن القروي ( يستمد قوته من الخيال، فكما ولها

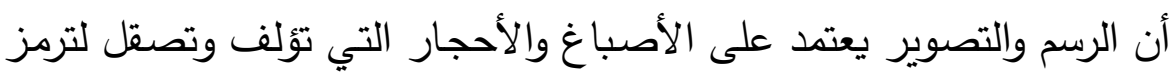
إلى طبيعة جميلة، أو فتنة ساحرة، أو عبقرية نادرة، نجد التشبيه يشاركهما في

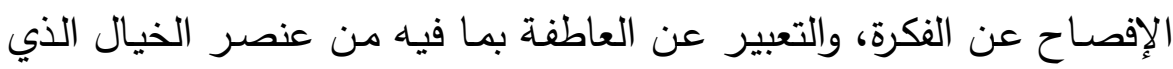
يقابل تلك الأصباغ والأحجار) (') ويعود القروي إلى التصوير الاستعاري مرة أخرى في قوله "كاسَ السـلامِ؛ إذ شبه السلام بالخمر على سبيل الاستعارة المكنية، وهذه الاستعارة تشعر بلذَّة السـلام وجمالـه وتأثيره الإيجـابي في نفوس البشر ، وأنـه يجعل حياتهم أكثر

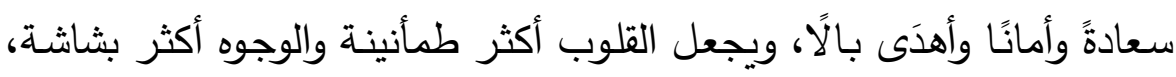

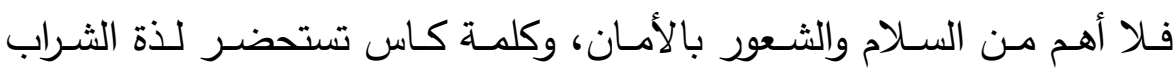
ومتعته، فالثاعر يخيل للسامع أنه يسقي السلام في كأس لأعدائه بيده،وأنهم بسبب هذا الكأس سينسون عداوتهم له، وفي التعبير بقوله "من يدي" مزيد من التحبب والترغيب في الاستجابة لرغبة الثاعر في تحقيق السلام.

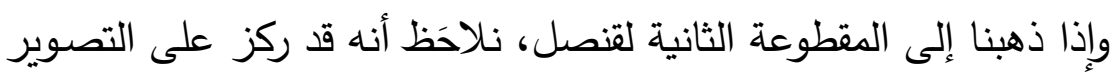
الاستعاري، فقد كرره في أكثر من موضـع مـن المقطوعـة ولم يستخدم لونًا

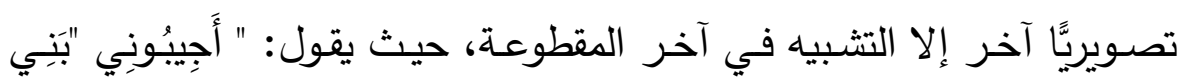

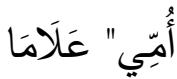

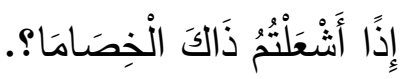

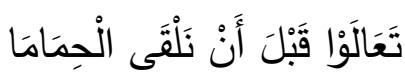

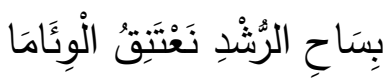

(1) البيان في ضوء أساليب القرآن، أ-د.عبد الفتاح لاثين، ص ؟ ـ ا،دار الفكر العربي-

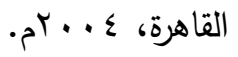


أثر التصوير البياني والتحسين البديعي فِ أداء معنى الصفح هٍُ الشعر المهجري: القروي

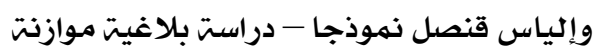

حوليت كليت اللغت العربيت بإيتاى البارود (العدد الثالث والثلاثون)

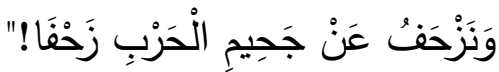

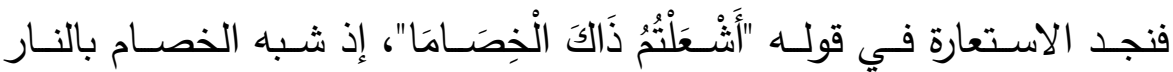
المشتعلة ثم حذفها وذكر شيرًًا مـن لوازمها وهو الاشتعال، وهذه الاستعارة توحي بأن هذا الخصام سرعان ما يحدث؛ فعند أعدائه دواعيه، وأسبابه جاهزة لديهم، وكأنهم يتحينون الفرصة لذلك، فقلوبهم تمتلـئ منه حقدًا وحسدًا، وهذه المشاعر السلبية تأكل في قلوب أعداء الثاعر كأنها النار المشتعلة، والتعبير: "أَثْعَلْتُعُ" يصلت الضـوع على أثثر هذه المشاعر الضـارة بصـاحبها قبل غيره، وأنها ذات اثر فاعل بشكل سلبي على البشر • وتتعانق مع الصورة السابقة صورة استعارية أخرى في قوله "بساح الرشد"؛ إذ شبه الرشد بمكان كبير لله ساح، ثم حذف المشبه به وذكر شيئًا من لوازمـه، وهو السـاح، وهذا التصـوير يشعر برحابـة التفكير الرشيد الذي يكون نتيجـة

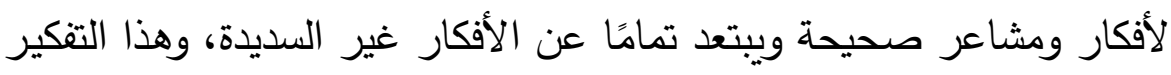

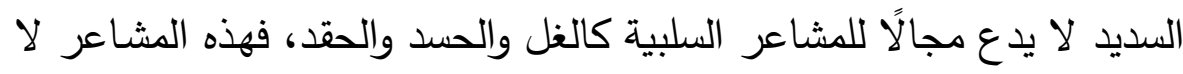

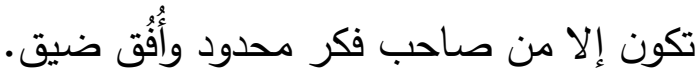

ويستكمل قنصل خطوط لوحته بتشبيهه الوئَام بعقيدة تُعتنَق في قوله "نَعْتَنِقُ الْوِيَّامَا"، ثم حذف المشبه به وذكر شينًا من لوازمه وهو الاعتناق، على سبيل

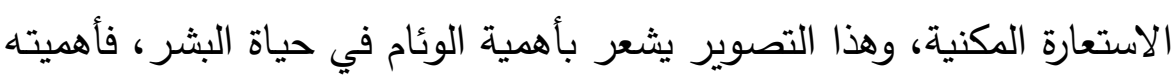

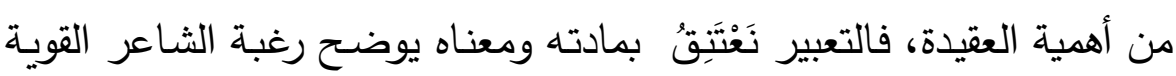
في ملازمة الوئام مثل ما يلتزم الثخص بعقيدته، فبه يعيش الناس في سلام وأمان. ويترك قنصل التصسوير بالاستعارة إلى التصسوير بالتشبيه في قولـه: " جَحِيمٍ

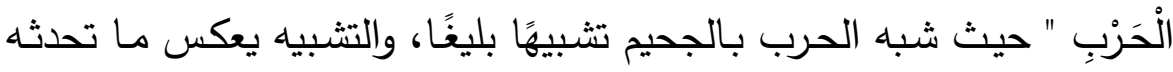
الحرب من دمار وهلاك للبشر، ويصور ما ينتج عنها من خسائر بشرية، وما تسببه من آلام نفسية لمن يفقد غالي أو عزيز في تلك الحرب. 
أثر التصوير البياني والتحسين البديعي هِّ أداء معنى الصفح فِ الشعر المهجري: القروي

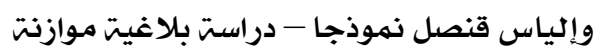

حوليت كليت اللغت العربيت بإيتاى البارود (العدد الثالث والثثلاثون)

وإذا جئنا لمقطوعة القروي الثالثة نجده يبين فيها كيف أنه ذلل لألعدائهـ طريق الحب وفرشه لهم بالزهور والورود، وفي مقطوعته هذه قد تتوع أسلوبه التصويري بين الاستعارة والتشبيه؛ إذ يقول:

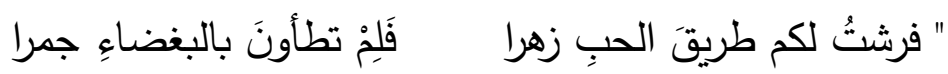

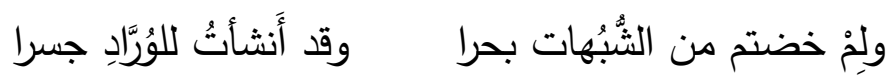

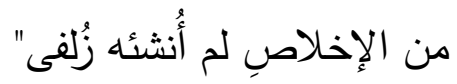

ففي قوله: "فرشتُ لكم طريقَ الحبٍ زهرا" شبه الحب بشيء مادي يمشي رهي ويُذهب إليه، ثم حذف المشبه به وذكر شيئًا من لوازمـه وهو الطريق، على سبيل الاستعارة المكنية، وهذه الاستعارة تجعل للحب طريقًا يستحق أن تُتَكبد مشاقه وتُتجشم صعابه، ذلك الطريق الذي يفرشه القروي بالأزهار ، والتي مجرد

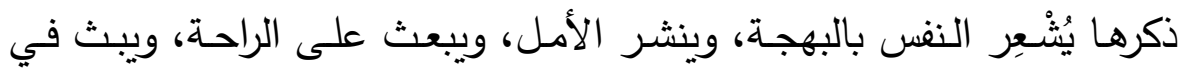
النفس الهدوء والطمأنينة. والاستعارة " وسيلة اكتثاف العالم الداخلي للشاعر بكل ما فيه من خصوصية وتفرد وتميز لا تستطيع اللغة العادية التجريدية أن توصله إلى القارئ. (') ويترك القروي التصوير الاستعاري ليصور بالتشبيه في قوله "ولِّْ خضتم

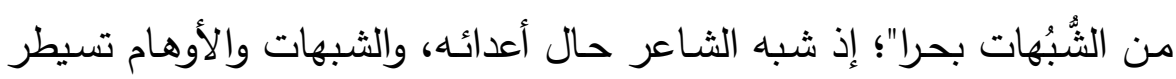

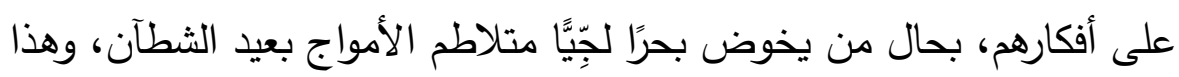
التشبيه يصور حالهم من التخبط والضلال وعدم الأمل في النجاة. وكلمة " الثُُّبهات " تعكس ما كان عليه أعداء الشاعر من تخبط وضياع وكثرة الأخطاء واستهلاك الطاقة في ما لا يفيد، استهلاكها في مشاعر سيئة تضرهم قبل غيرهم.

( (1) البلاغة فنونها وأفنانها،علم البيان والبديع - د / فضل حسن عباس ص س با ب، دار

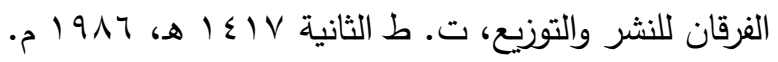


أثر التصوير البياني والتحسين البديعي فِ أداء معنى الصفح هٍُ الشعر المهجري: القروي

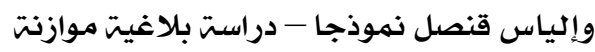

حوليت كليت اللغت العربيت بإيتاى البارود (العدد الثالث والثلاثون)

وحينما ننتقل إلى المقطوعة الثالثة لقنصل نجده يبين لأعدائه أنه سامحهم الثائه

على كل ما فعلوه معه، وغفر لهم كل ما وقع منهم وكل ما أخفوه في قلوبهم

تجاهه، وقد آثر في بيان ذلك: التصوير الاستعاري في تعبيره؛ إذ يقول:

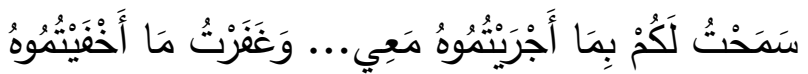

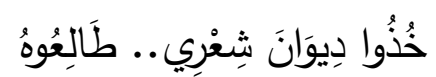

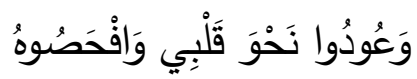

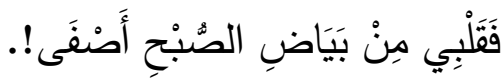

ففي قوله "وعودوا نحو قلبي وافحصوه"، يشبِّه حال أعدائه الذين يريد منهح أن يتأكدوا من صفاء قلبه وحبه لهم وخُلُوه من الحقد والحسد لهم بحال الأطباء الذين يفحصـون القلب ليتأكدوا مـن خلوه من الأمراض المهلكة، على سبيل الاستعارة التمثيلية، وهذه الاستعارة تكثـف عـن ثقـة قنصـل الثـديدة بنفسـه،

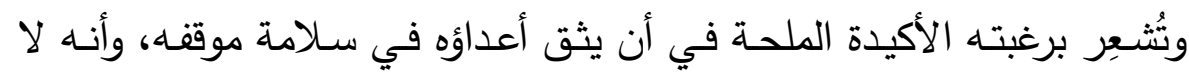
يحمـل لهم إلا كل مـودة ومحبـة، ممــا يـوحي بثـدة صـفح قنصـل وسـماحته المغرطة.

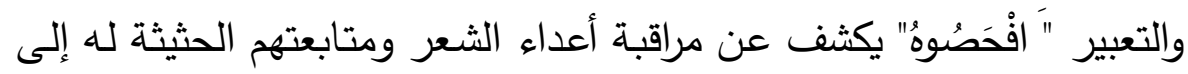
درجة أنهم أراضوا أن يعرفوا ما في قلبه، وهو يعلم بذلك ومع ذلك فلم يغضب مرفب بل يطلب منهم أن يأخذوا قلبه ويقموا بفحصه واستكثاف ما فيه من مشاعر دهر لعلهم يطمئنون ويرتاحون. والقروي في مقطوعته الرابعة يصور لنا عتابه لقومـه وأعدائهه برقة شعور في وني تحبب وتودد ، فهو يقول في مقطوعته:

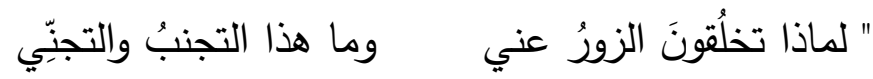

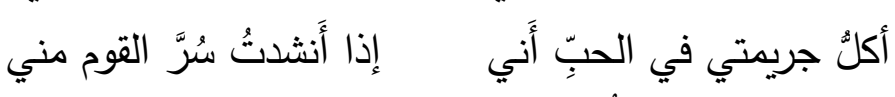
وألُْهِبَ من حماسته الأكفّا 
أثر التصوير البياني والتحسين البديعي فِ أداء معنى الصفح هٍُ الشعر المهجري: القروي

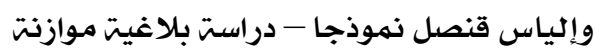

حوليت كليت اللغت العربيت بإيتاى البارود (العدد الثالث والثلاثون)

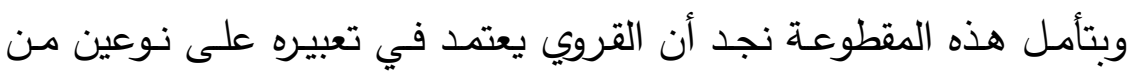

التصوير : التصوير الكنائي والتصوير الاستعاري.

فالتصوير الكنائي كما في قوله "أكلُّ جريمتي في الحبّ أَني إذا أَنثدتُ سُرَّر

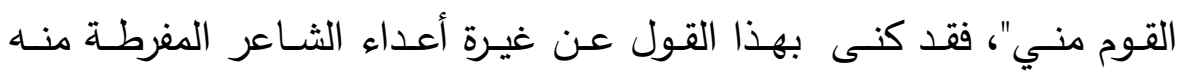

وحسدهم الدفين وحقدهم الثـديد تجاهـه بسبب نجاحسه وإعجـاب القوم بثـعره

وإنشاده، والكناية هذه توضتح حقد هؤلاء الأعداء وتلقي الضوء على حسدهم إياه، كما تُشعِر الكناية بتكرار هذا الفعل منهم( الحقد والحسد)، فهم يحسدونه في كل نجاح، فكم تضرر الثاعر من أسلوب هؤلاء وأصـابه الضيق الثديد، وقد عضد المعنى الكنائي أنسه جاء مصحوب بأسلوب الاستفهام المراد منـه هنه الأنكار والتعجب والذي بدوره يفصح عن مكنون الثاعر من عذاب وألم.

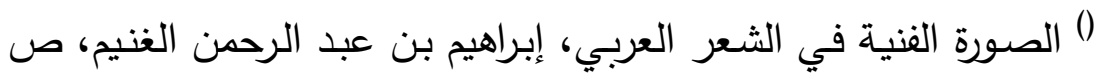

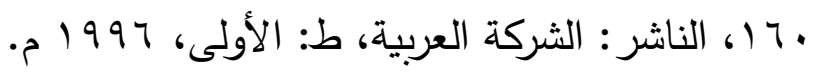

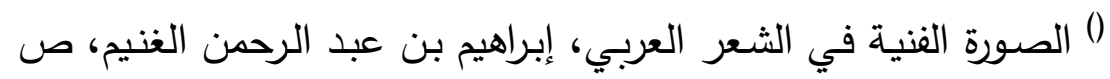
• 1 ا، الناشر: الثركة العربية، ط: الأولى، 1997 1 م.

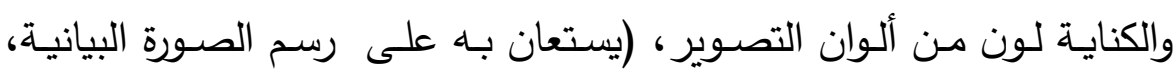
فيمنح التعبير جمالًا، ويهب المعنى قوة ورسوخًا)(')، وذلك لما تحمله الكناية من ستر للمعنى المراد مع خفاء لطيف يحبب للنفس عند استنباطه وظهوره. ويأتي دور التصوير الاستعاري في قول القروي: " وأُلْهِبَ من حماسته الأكفّا"

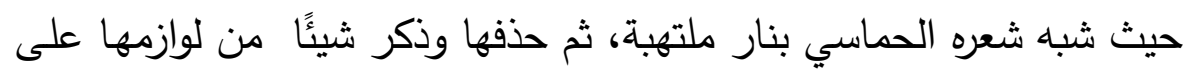
سبيل الاستعارة المكنية، وهذا التصوير يوحي بشدة حماسة شعر القروي وقوة تأثيره في النفوس وقدرته على تغيير الأفكار والقناعات، وكأنه النار الملتهبة التي تستطيع أن تغير خواص المواد المشتعلة بها؛ إذ تحيل كل شيء إلى رماد، مما أثار حساده وأعداءه، ودفعهم للمحاولة المتكررة للنيل منه.

(1) الصورة الفنية في الثعر العربي، ص • 1 1. 
أثر التصوير البياني والتحسين البديعي هِّ أداء معنى الصفح هٍِ الشعر المهجري: القروي

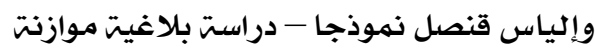

حوليت كليت اللغت العربيت بإيتاى البارود (العدد الثالث والثلاثون)

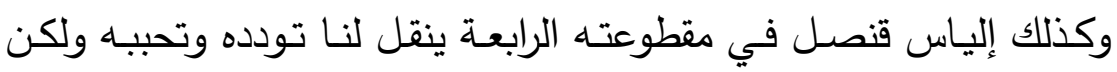

بطريقة مختلفة؛ إذ يقول:

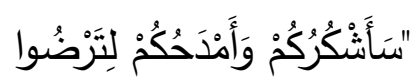

وَيَذْهَبَ عَنْكُمُ حِقْدُ وَبَغْضُ

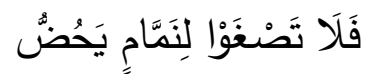

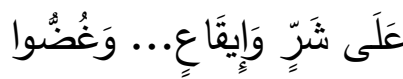

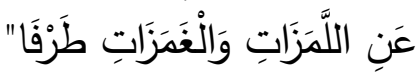

وأما عن استخدام قنصل للتصوير البياني في هذه المقطوعة فيلاحَظ أنه

لم يستعين بالصورة البيانية ولم يعبر بأي شكل من أشكالها؛ إذ إنه كان في حالة لا تتناسب والتصوير البياني الذي يستلزم الخيال والتحليق في الأفاق، وقد استعان في مقطوعته هذه للتعبير عن مكنون أفكاره بالأسلوب الخبري

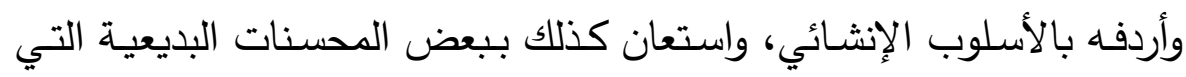
سيأتي عنها الكلام في حينه(')، فلم تُنْعِه في هذه المقطوعة إلا تلك الأساليب لبيان مراده والكثف عن مبتغاه ومقصده والقروي في مقطوعته الخامسة يستمر في عتاب أعدائه الذين يحملون لـه العداوة والبغضاء؛ إذ يقول: "لماذا كلما ألقي نشيدا ألاقي منكم سهماً جديداً

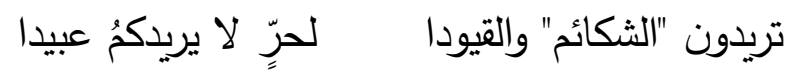

ولا يرضسى لكم ذُلَّلَ وخَسفا"

ولـو تأملنـا التصـوير البياني في هذه وهينا المقطوعـة لوجدنا أن القروي يعبر بالكناية والاستعارة.

ففي قولـه "ألاقي مـنكم سـهماً جديـداً"؛ إذ شـبه هجـاءهم الشـيد المستمر بالسهم القاتل على سبيل الاستعارة التصريحية الأصلية، وهذه الاستعارة تصور 
أثر التصوير البياني والتحسين البديعي فِ أداء معنى الصفح هٍُ الشعر المهجري: القروي

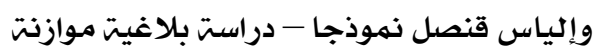

حوليت كليت اللغت العربيت بإيتاى البارود (العدد الثالث والثلاثون)

حدة هجائهم وكثرة نقودهم، كما تشعر بثدة إيجاع الثاعر وإيلامه من هجائهم المستمر ، ونقدهم اللاذع الهدام.

وتتضـح الكناية في قولـه: " تريدون الثكائم والقيودا لحرّ لا يريدكٌُ عبيدا ولا يرضى لكم ذُلَّل وخَسفا "؛إذ كنى بهذا القول عن رغبة أعداؤه القوية في تقييد شعره وتحجيم فكره في الوقت الذي لا يرضى لهم الذل والهوان، وهذه الكناية

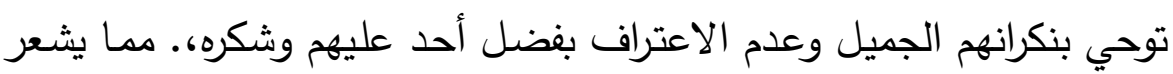
بخستهم وقلة شئنهم.

وأما إلياس قنصل في مقطوعته الخامسة فيستمر في خطاب قومـه بطريقة

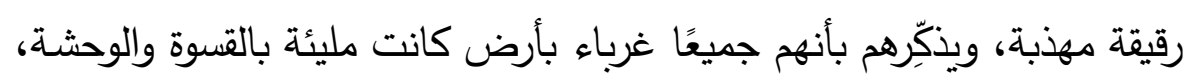

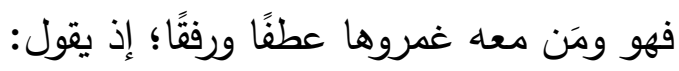

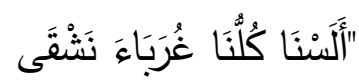

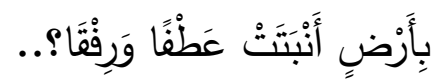

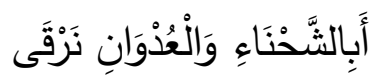

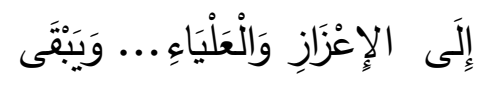

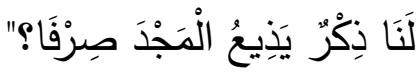

نلاحظ أن قنصل قد عبر في المقطوعة بالتصـوير الاستعاري والتصـوير

الكنائي.

فقي قوله "بأرض أنبتت عطفاً ورفقا" استعارة؛ إذ شبه العطف والرفق بنبت أخضـر غض ينبـت ويترعـرع ثم حذف المشبـه بـه وذكـر شـينًا مـن لوازمـهـ

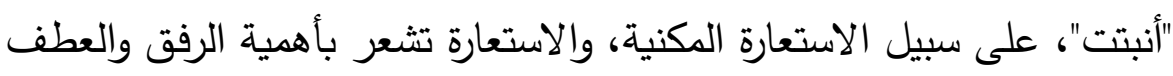
وقيمتهما الكبرى في الحياة، فكما أن النبات بأنواعه يضفي على الدنيا البهجة وينشر العبير الطيب، ويدخل على النفس الراحة والهدوء، كذا كل من العطف لف والرفق يضفي على الدنيا طعمًا ولونًا خاصًا ويدخل الأمل في القلوب، ويجعل

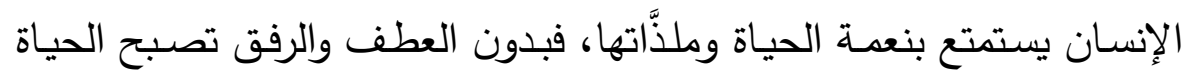


أثر التصوير البياني والتحسين البديعي فِ أداء معنى الصفح هٍُ الشعر المهجري: القروي

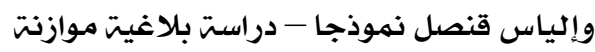

حوليت كليت اللغت العربيت بإيتاى البارود (العدد الثالث والثلاثون)

جافة مُشْقية غير مرغوب فيها، والتصوير يوضـح كذلك مدى المعاناة التي

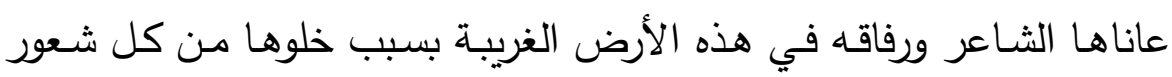
طيب، ولم يكن بها رفق ولا عطف، ثم وُجِدا بعد عناء وشقاء مريرين.

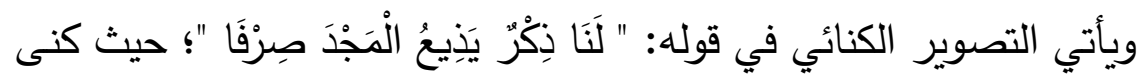
بهذا القول عن ذِكْرِه الحسن المشرف، وافتخـاره بنفسـه وبالمجد الذي حصل عليه بسبب ذِكُرهِ، وقد أشـار قنصل في مقطوعته الأولى في أول جملـة من جملها إلى أنه كان سببًا في تحصيل المجد لقومـه؛ إذ عبَّد طريقه لهم وذلله، فقد قال " رَصَفْتُ لَكُمْ سبيل المجد رَصْفَا "،وهذه الكناية توحي امتلاكه للشرف

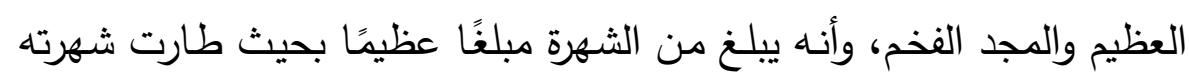
في الآفاق، وسمع به الداني والقاصي. وقد ناقش كل من الثاعرين في المقطوعة السادسة فكرة مختلفة عن ون فكرة الآخر ، فالقروي في مقطوعته يؤكد ثقته الثديدة بنفسه، وأنه يعرف قدره جيدًا ولا يستطيع أحد أن يقدح في كتاباته، إذ يقول: فقد مكّنتُ بالتهذيب تُرسي

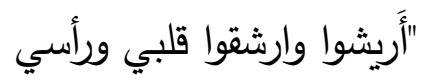

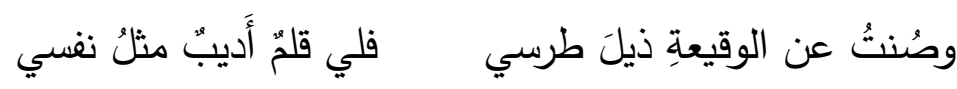
عن القولِ السفيهِ عفا وعفّا"

وقد أخرج القروي المعنى الذي ينطوي عليه ضميره في هذه المقطوعة عن طريق التعبير التصويري المتنوع؛ إذ جاء ما بين الاستعارة والتثبيه. فقد شبه كتاباته بالترس الذي هو قطعة من الحديد ونحوه في قوله "فقد مكّنتُ بالتهذيب تُرسي"، ثم حذف المشبه على سبيل الاستعارة الأصلية، وهذه

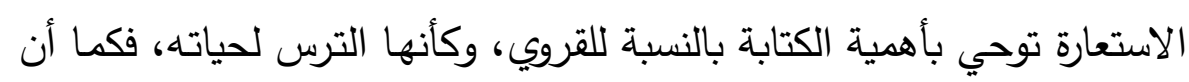
الألة تتوقف بدون الترس، كذلك حياة الشاعر تتوقف بدون الكتابة، فهو لا لاهيه يشعر بذاته بدونها، وفي إيثار القروي للفظ الترس : إشعارٌ بأن كتابته كانت 
أثر التصوير البياني والتحسين البديعي فِ أداء معنى الصفح هٍُ الشعر المهجري: القروي

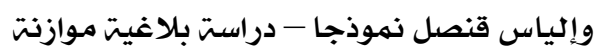

حوليت كليت اللغت العربيت بإيتاى البارود (العدد الثالث والثلاثون)

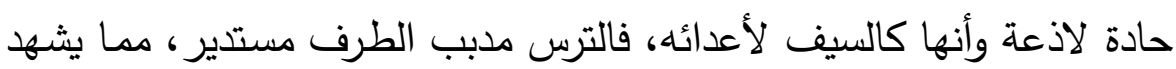
بدقة تعبير الثاعر - ماع

وتتعانق استعارة أخرى مع الاستعارة السابقة في قول القروي "وصُنتُ عن الوقيعِِ ذيلَ طرسي"؛ إذ شبه كتاباته بالثوب، ثم حذف المشبه بـانه وذكر شينًا

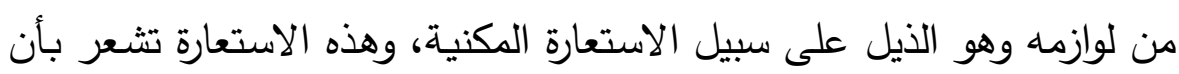
كتاباته جميعها مصانة صيانة كاملة، ولم يصب أي جزء منها الوقيعة، وأنه لم لم لماني يترك لأحد الفرصـة لتغييرها أو تحريفها أو تبديلها، أو حتى الإيقاع بـه، مها يوحي بحرص الثاعر وتحسُبه لكل موقف. ولم تكن الاستعارة هي الأداة التصويرية الوحيدة التي استعان بها القروي في هذه المقطوعة؛؛ إذ وجد في التشبيه كذلك مـا يبرز بـه فكرته ويحقق بها

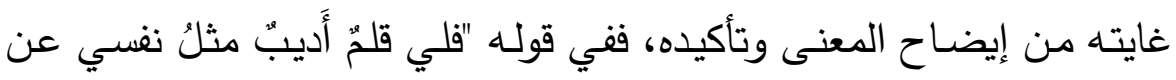
القولِ السفيهِ عفا وعفّا"؛ شبه القلم الذي يكتب بـه بنفسه الأبِيَّة العفيفة، وهذا التشبيه يوحي بفخامـة قلمـه وكتابته وبعدها عن الابتذال ونئيها عن الرذيلة

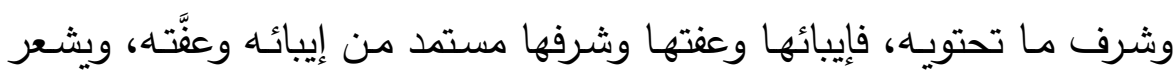

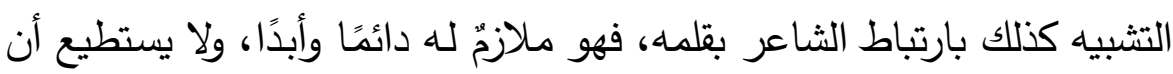
يبتعد عنه أو يفارقه لدرجة أنه قد أخذ من صفاته النفسية والخُلقية. وقد تعاون تتكير كلمة " قلم " مـع التشبيه في الإشعار بعظمة هذا القلم وكثرة

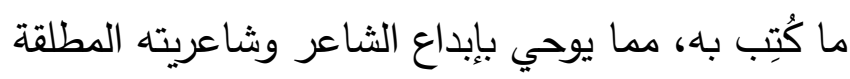

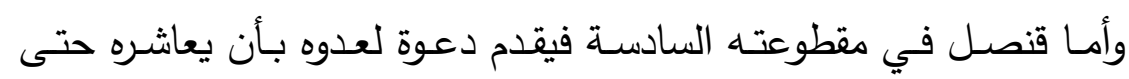

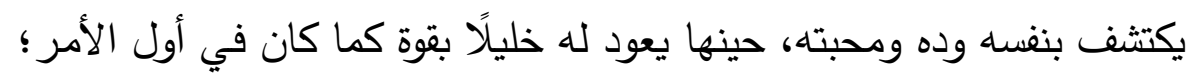
لأن وده لم يتأثر بما فعله معه وكذلك حبه له وده لا يفتر أبدًا.

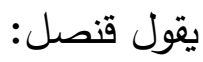

$$
\begin{aligned}
& \text { "عَدُوِي لَوْ تُعَاثِرُنِي قَلِيلَ }
\end{aligned}
$$

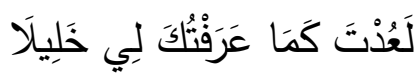


أثر التصوير البياني والتحسين البديعي ِِِ أداء معنى الصفح ِِّ الشعر المهجري: القروي

وإلياس قنصل نموذجا - دراست بلاغيتة موازنت

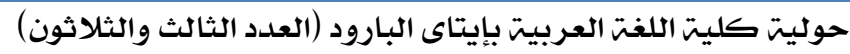

فَعَهْدِي بَعْدَ مِينِلَكَ لَنْ يَحُولَا

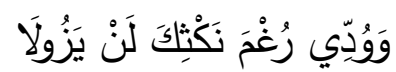

وَجَمْرُ مَحَبَّتِي هَيْهَاتَ يُطْفَى "

والتصسوير الذي اعتمد عليه قنصل في مقطوعته هذه هو التشبيه، وذلك

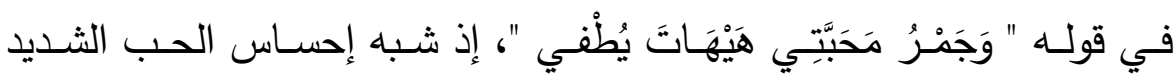
بالجمر المتقد تشبيهًا بليغًا، وهذا التشبيه يوحي بأن قلب الثاعر ما زال نابضًا

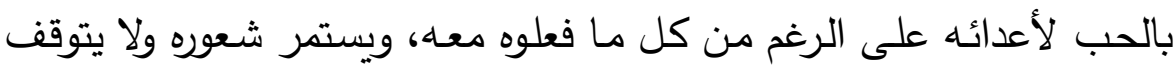
مهما فعلوا، ويؤكد هذا المعنى التعبير بالفعل المبني للمجهول " يُطْفي "الذي معني يوحي بأن حب الثاعر لمن يكنون له العداوة وتمتلئ قلوبهم بحسده، واحترامه لهم وتقديره إياهم، لا يتوقف ولم يُنْزَع من قلبه.

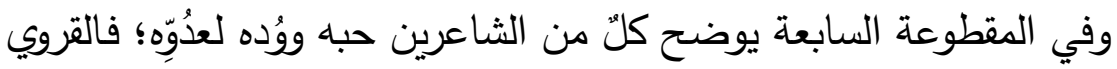

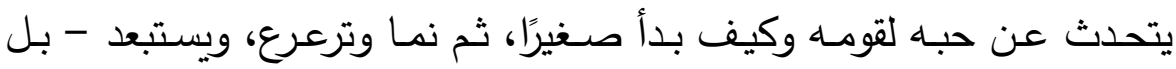

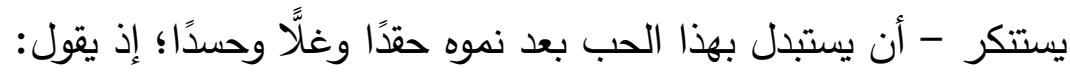

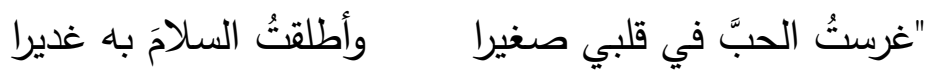

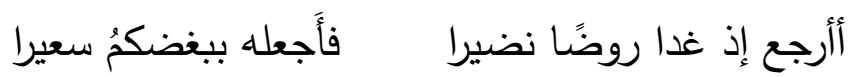

وأقطف منه جمر الحزن قطفا"

والقروي في مقطوعته هذه يتنوع تصويره بين الاستعارة المكنية والاستعارة

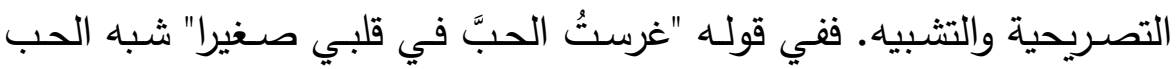
بنبتـة صـغيرة، ثم حذفها وذكر شينًا مـن لوازمها وهو الغرس، على سبيل

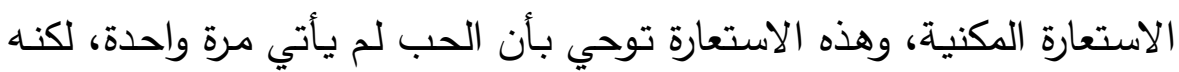

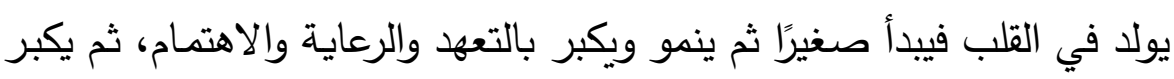

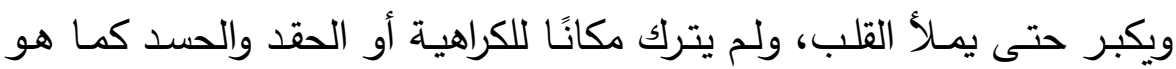
الحال مع شاعرنا، ويؤكد هذا المعنى قوله "صغيرا". 
أثر التصوير البياني والتحسين البديعي هِّ أداء معنى الصفح فِ الشعر المهجري: القروي

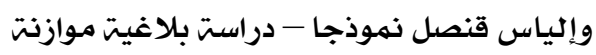

حوليت كليت اللغت العربيت بإيتاى البارود (العدد الثالث والثلاثون)

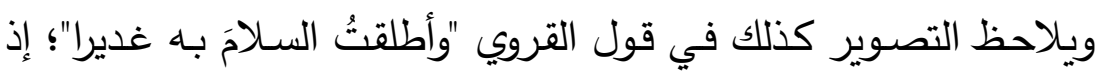

شبه الحب مرة ثانية بالغدير، ثم استعار الغدير للحب على سبيل الاستعارة التصـريحية الأصـلية، وهذا التصـوير يثـعر بنمـو الحب في قلب لب الثـاعر وازدياده حتى صار وكأنه نهر صغير يضم بين جنبيه عواطف كبيرة عظيمة، كما تشعر الاستعارة بقيمة الحب وأهميته، فأهميته من أهمية الغدير للإنسان الذي يكون في مكان جدب مقحل ثم يظهر لله غديرًا، فالغدير وإن كان صغيرًا

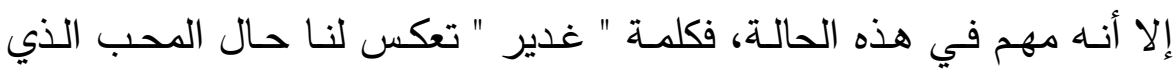
يشعر بالسلام من هدوء وصفاء ذهن ونقاء سريرة. ويشبه القروي شعوره بالحب للمرة الثالثة بالروض النضير في قوله "أرجع إذ فاء غدا روضًا نضيرا"؛ على سبيل الاستعارة التصريحية الأصلية، وهذا التصوير

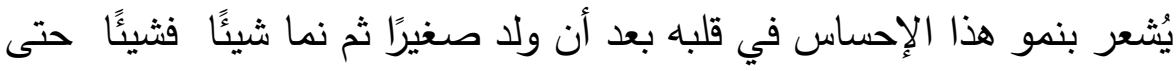
بدى وكأنه غدير ، ثم نمى أكثر فأكثر حتى أصبح روضًا كبيرًا وقد تفرُّعت

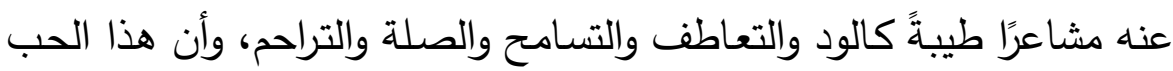

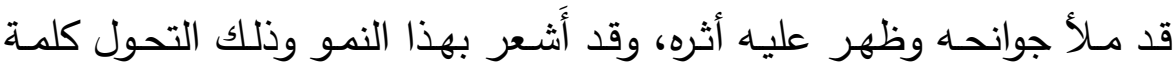
"غدا".

وفي المقطوعة نفسها، بعد أن انتهى القروي من تصوير الحب، اتجه إلى تصوير الحزن لكن هذه المرة عن طريق التشبيه، وذلك في قوله "وأقطف منه جمر الحزن قطفا"؛ إذ شبه الحزن بالجمر تشبيهًا بليغًا، والتشبيه يشعر بأن الحزن جمر متقد لا يطفأ أبدًا، يحرق صاحبه ويمرر حياته ويجعلها كمدًا وهمَّا

دائمًا.

وتتعانق الاستعارة مـع التشبيه السـابق؛ إذ شبه الجمر بثـارٍ تُقُطَف، ثم حذفها وذكر شينًا من لوازمها وهو القطف، على سبيل الاستعارة المكنية، وهذه الاستعارة تبرز المعنى وتؤكده، وهو أن كل شيء لله نتيجة وثمرة، فكما أن 
أثر التصوير البياني والتحسين البديعي فِ أداء معنى الصفح هٍُ الشعر المهجري: القروي

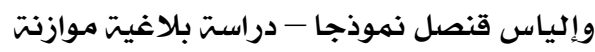

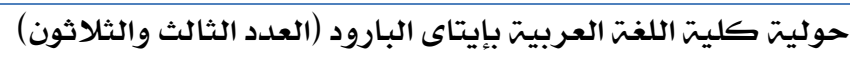

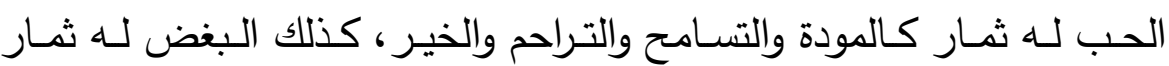

تُقُطَف، وأهمها الحزن والهح والثر .

وأما قنصل ففي مقطوعته السابعة فيخبرنا بأنها لا يكره عدوه وأنه لا يرغب وانب في شقائه؛ إنما يرجو لله الرضا والراحة وينصحه بأن يكف عن عداوته، لأنه في النهاية أخُّ له؛ إذ يقول:

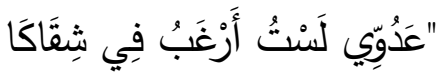

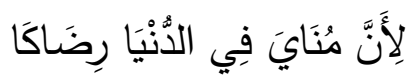

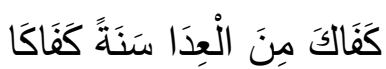

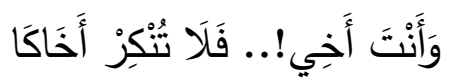

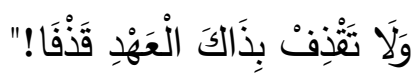

ويلاحَظ أن قنصـل في مقطوعتهـ هذه لـم يعبر بـأي شكل مـن أشكال

التصوير إلا بالاستعارة المكنية ولمرة واحدة، في آخر المقطوعة في قوله "وَلَا

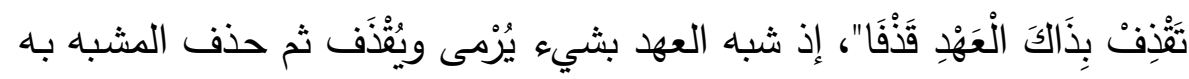

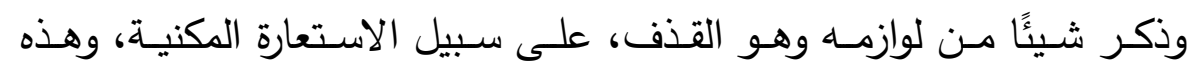

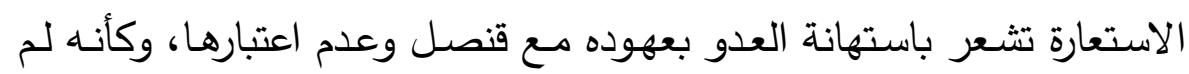
يعاهده أصلًا، وتوحي كذلك بقسوة عدو الشاعر وجمود قلبه، وأنه لا عهد لله

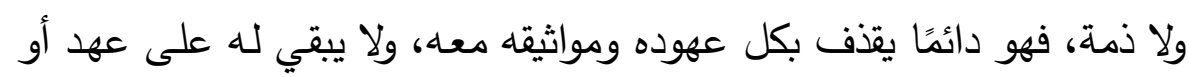

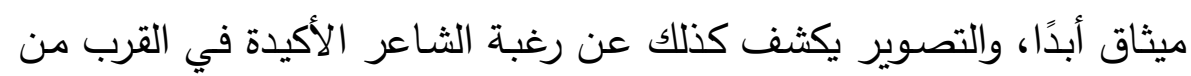
عدوه ومصالحته، كما يوضح شدة صفح قنصل وتسامحه.

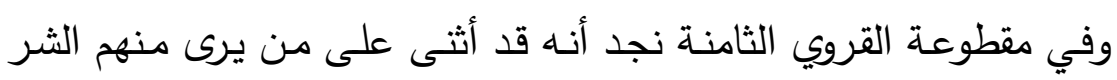
ويتغاضسى عن ذلك، ثم يدعو من حوله إلى المحبة والمودة، فبدون المحبة ينتشر الفساد والكراهية؛ إذ يقول:

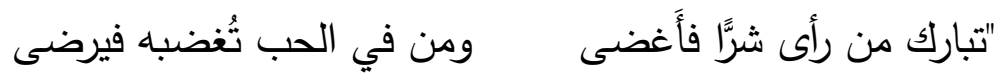

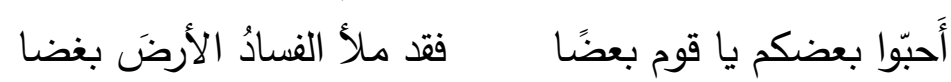


أثر التصوير البياني والتحسين البديعي هِّ أداء معنى الصفح فِ الشعر المهجري: القروي

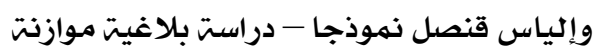

حوليت كليت اللغت العربيت بإيتاى البارود (العدد الثالث والثلاثون)

وكاد الحب بين الناس يُخفى "

والقروي في مقطوعته هذه لم يحتج إلى التعبير التصويري بل إننا نجده قد

آثر التعبير بالأسلوب المجرد:إذ هذه الطريقة هي الأنسبُ مـ وجهـة نظره للتعبير عن المعاني التي أوردها في المقطوعة، فقد رأى في الأساليب التعبيرية غير التصويرية ما ينهض بالمعنى المراد، فالقروي قد دعا لمن يتغاضى عن الشر ويتعامل بالتسـامح والحب بالبركة، وكذلك يحث قومـه على الحب؛لأنـه يثعر أن الحب كاد أن يختفي من بيئته، فكل هذه المعاني يمكن أن يبرزها

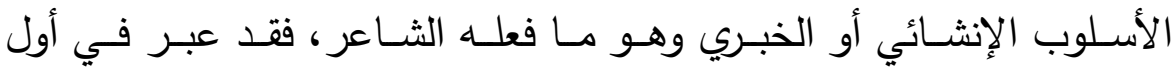
المقطوعة بالأسلوب الإنشائي وفي آخرها بالأسلوب الخبري.

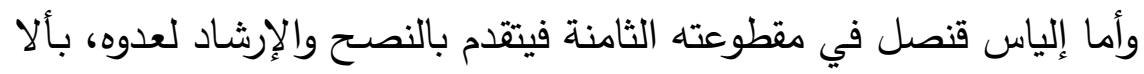

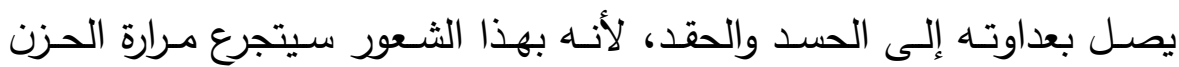

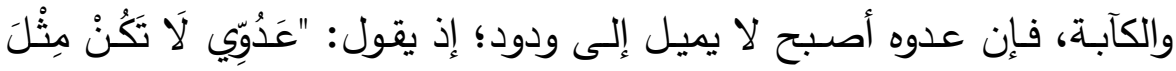
الْحَسُودِ

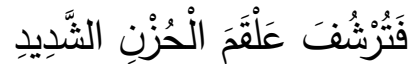

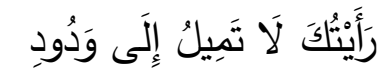

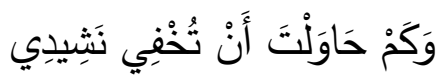

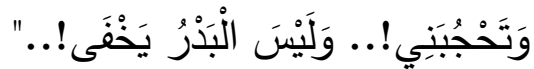

وقد استعمل قنصل في مقطوعته هذه من الصور البيانية التشبياه والكناية.

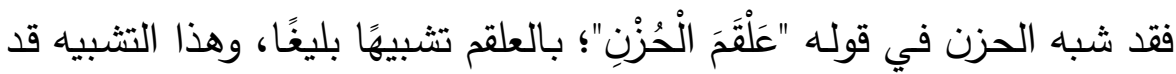
أبرز أثر الحزن الشديد على النفس وقدرتهـ الفائقة على تدميرها، إذ يجعل صاحبه وكأنه يتجرع شراب مرلا يُتَحَمل طعده، ولم يجلب هذا الشراب لشاربه إلا العناء والتعب، والهح والضيق.

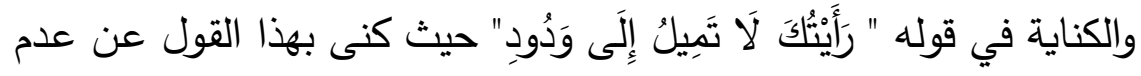
مودة أو محبة عدوه لأي أحد، والتصوير يوحي بقسوة عدوه وجفاف مشاعره، 
أثر التصوير البياني والتحسين البديعي فِ أداء معنى الصفح هٍُ الشعر المهجري: القروي

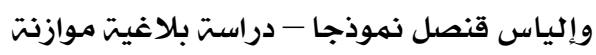

حوليت كليت اللغت العربيت بإيتاى البارود (العدد الثالث والثلاثون)

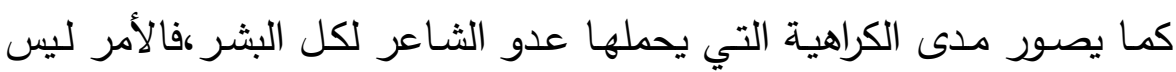
قصرًا عليه وحده، مما يوحي بقبح عدوه وخبث نيته، وأن العيب فيه هو لا في غيره. ثم يكني بقوله: " وَكَمْ حَاوَلْتَ أَنْ تُخْفِي نَشِيِيدِي... " إلخ عن إصرار عدوه على إخفاء محاسنه الكثيرة ومآثره العظيمة، والكناية تكثف عن حقدهم الدفين لقنصل وكراهيتهم الثديدة له، كما تبرز سوء نواياهم وقبح مقاصدهم، فقد كانوا يحرسون دومـا على إخفاء محاسنـه، وادعاء المسـاوئ لـه،لكن هيهات،فهم ولا غيرهم لا يستطيعون إخفاء البدر ونوره.

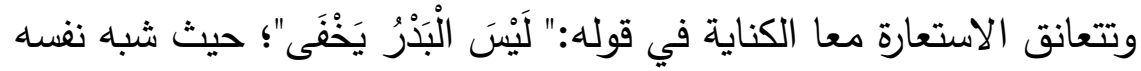

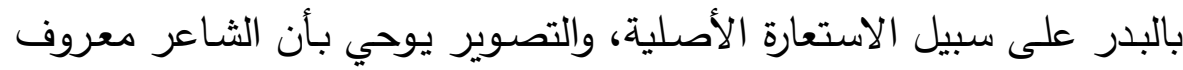
للجميع بصفاته الطيبة ومحاسنه التي لا تخفى على أحد مهما حُوِلَ إخفائها،

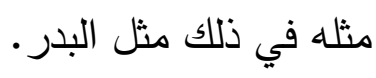
وقد تودد الشاعران لأعدائهما في المقطوعة التاسعة، لكنَّ كل شاعر منهما تودد بطريقة تخص طب يعته؛ فالقروي ينادي عدوِه بلفظ "أُخهيَّ"، ويُشْبِِره بمعنى الأُخُوةة، ويحثه على سعة الصدر والتفكير بطريقته الطيبة، عله يجد لكل مذنب عذرًا، ويجود على كل هجاء بشكر مهما كان هجاؤه؛ إذ يقول:

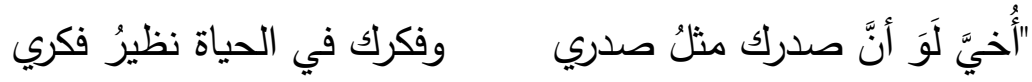
وجدتَ لكلّ ذنب كلّ عذر وجُدَّ لكل هجّاءٍ بشكرِ وإن هو زاد طغيانًا وعسفا"

ويعبّرِ القروي في مقطوعته هذه بالتصوير الكنائي فقط في قوله " وإن هو زاد طغيانًا وعسفا "؛ حيث كنى بهذا القول عن زيادة ظلم عدوه وتجَبُّرِ، وهذه الكناية تصور جبروت هذا الرجل وعدوانه، وتوضـح إلى أي مدى كان القروي متسـامحًا متسمًا بالصفح والعفو إلى درجة يمكن معها إيجاد العذر للطاغية إية وتقديم شكر للهجَّاء. 
أثر التصوير البياني والتحسين البديعي فِ أداء معنى الصفح هٍُ الشعر المهجري: القروي

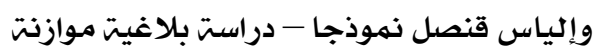

حوليت كليت اللغت العربيت بإيتاى البارود (العدد الثالث والثلاثون)

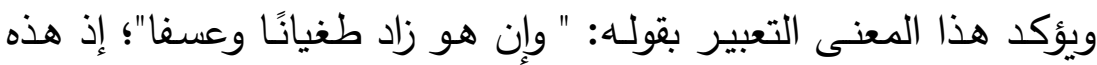
الجملة تثتمل على " إن " الثرطية، فهي بمثابة الاحتراس من الفهم الخاطئ

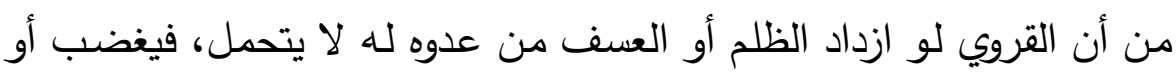

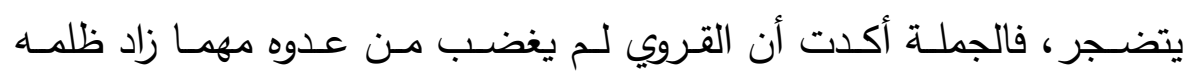
وعسفه، ومنعت هذا التوهم وقطعتا ذلك الثك، وأكدت تسامح القروي الثديد وصفحه العظيم.

وأما إلياس قنصل ففي مقطوعته التاسعة قد استمر في خطاب عدوه لكنه كان يخاطبه بلفظ غير الذي خاطب به القروي عدوه؛ إذ كان القروي يخاطب

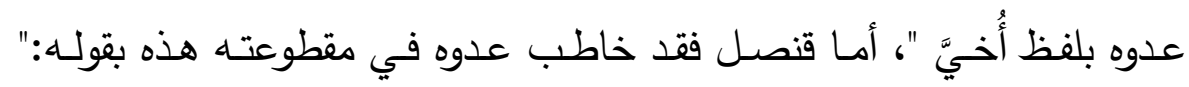
عدوي "،ومع أن قنصل كان يخاطب عدوه بلفظ " عدو " في مقطوعته هذه إلا

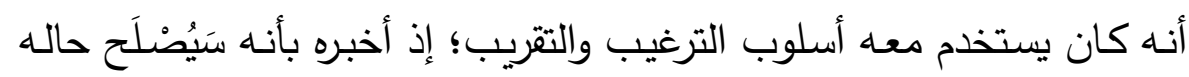

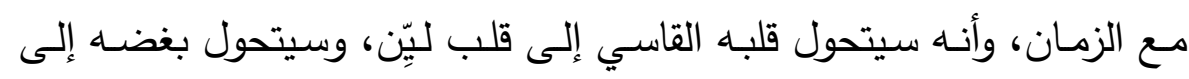
حنان، ثم يخبره بأنه سيمدحه ولا يكون منه لله هجاء أبدًا.

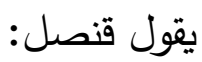
"عَدُوِي سَوْفَ يُصْلِحُحَكَ الزَّمَانُ

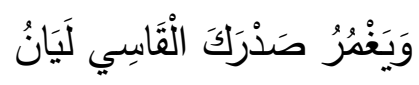

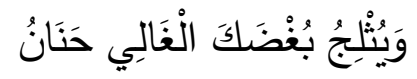

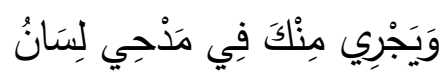

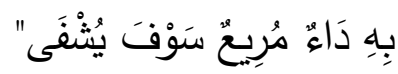
وقنصل في مقطوعته هذه يعتمد على نوعين من التصوير ، وهما: الاستعارة والمجاز المرسل.

فالاستعارة في قوله: " يَغْمرُ صَذْرَكَ الْقَاسِي لَيَانُ" حيث شبه الليان بثَوب أو رداء يغطي ويغـر ، وحذفـه وذكر شـيء مـن لوازمــه على سبيل الاسـتعارة المكنية، والتصوير يوحي بثقة قنصل الثديدة في أن الزمان ومهع مرور الوقت ولت ودئ 
أثر التصوير البياني والتحسين البديعي هِّ أداء معنى الصفح هٍِ الشعر المهجري: القروي

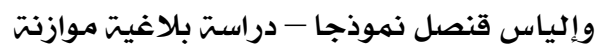

حوليت كليت اللغت العربيت بإيتاى البارود (العدد الثالث والثلاثون)

سيمحي قسوة قلب عدوه، وليس هذا فحسب بل أن اللين والرحمـة ستغطيان قلبه وتغمراه، والثاعر بهذا التصوير يُطَمْئن نفسه قبل عدوه، وكأنه يمني نفسه بصلاح حال عدوه، وأنه سيأتي يومًا يسلم فيه من عداوته.

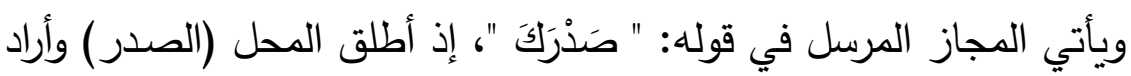
الحال فيه (القلب) لعلاقة المحلية، وهذا المجاز يوحي بأن القسوة قد تمكنت فيت فئل من قلب عدو الشاعر وأحاطت بـه لدرجة أنها أصبحت تملأ صدره، والمجاز كذلك قد أبرز علاقة القلب بالصدر وأنهما متلازمان، لدرجة أنه يصح التعبير

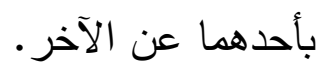

ويتضـح المجاز المرسل كذلك في قوله: " وَيُنْلْجُج بُغْضَكَ" حيث أطلق الحال

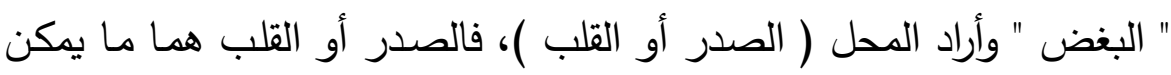
إثلاجهما، والتصوير المجازي يوضح قوة هذا الإثلاج وذلك الرضا وأنه من قوة تأثيره يتعدى الصدر أو القلب إلى كل ما يحمـلاه من مشـاعر سيئة فيمحها ويبدلها إلى مشاعر طيبة. ويلاحظ (أن الأساس النفسي للمجاز المرسل هو تداعي المعاني إذ إن هذا المجاز يسوغه التلازم الذهني، فالسبب والمسبب متلازمان ذهنًا وزمانًا ومكانًا، وكذلك الكل والجزه، والحال والمحل) ('). فالمجـاز في هذا التعبير أجمل مـن الحقيقة، ويعضد هذا الكـلام كـلام ابن ولن رشيق؛ حيث يقول: (والمجاز في كثير من الكلام يأتي أبلغ من الحقيقة وأحسن موقعًا في القلوب

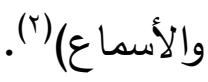

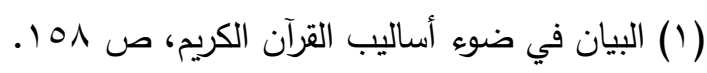

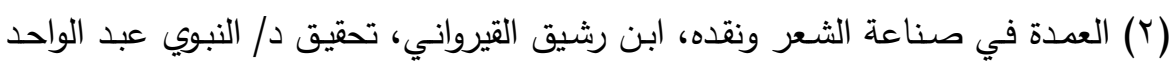

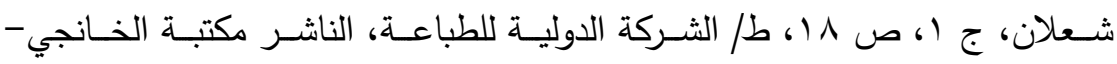

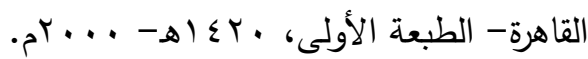


أثر التصوير البياني والتحسين البديعي فِ أداء معنى الصفح هٍُ الشعر المهجري: القروي

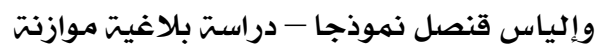

حوليت كليت اللغت العربيت بإيتاى البارود (العدد الثالث والثلاثون)

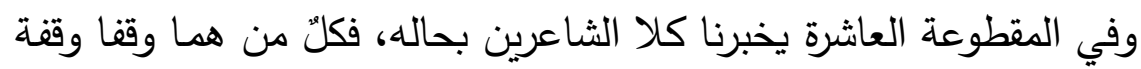

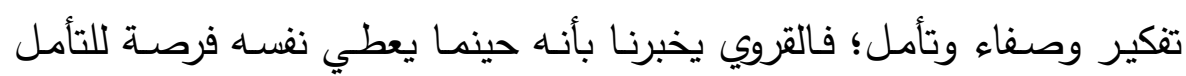
والتتكير في الوجود يجد كل منتقم وحاقد يعذب نفسه بأفكاره السلبية ومعتقداته وله السيئة، في حين أنها يجد نفسـه منسجمة مـع آلته الموسيقية (العود)، فرحًا مسرورًا، بسبب ما يحمله من مشاعر الحب والسلام، إذ يقول:

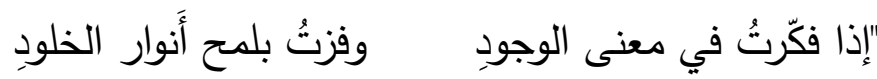

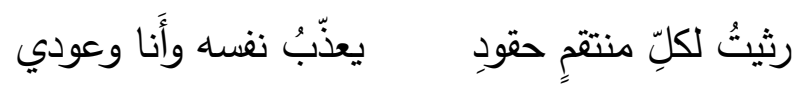

نروح ونغتدي شدوًا وعزفا"

والقروي في مقطوعته هذه يعبر بالتصوير الكنائي في قوله "وفزتُ بلمح

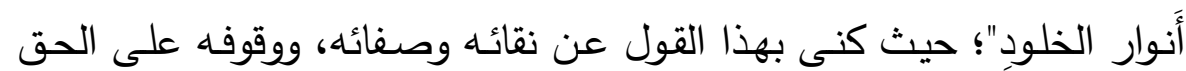
ووضعه الأمور في نصابها الحقيقي، مما يوحي بتمتع القروي بالعدل، والقدرة على قول الحق والحيادية مهما كلفه الأمر.

ثم يعبر بالتصوير الاستعاري في قوله: " وأَنا وعودي نروح ونغتدي "،فقد ولاديه شبه عوده بشخص يروح ويغتدي ثم حذفه وذكر شيء من لوازمه على سبيل

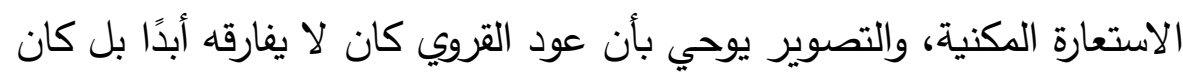

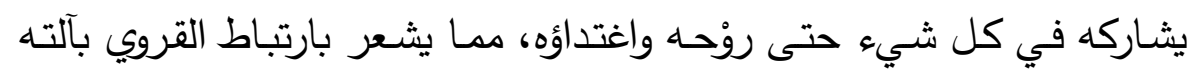
الموسيقية، وأنها ذات قيمة كبيرة بالنسبة له، وتكثف الاستعارة كذلك عن مرح القروي والسعادة التي يتمتع بها في حين أن غيره من الذين تمتلى قلوبهم غيظًا وانتقامًا يتعذبون.

وأمسا قنصل ففي مقطوعته العاشرة يخبرنـا بأنـه حينما يجد نفسـه قريبًا من السماء يصلي لعدوه ويدعو له، ويظل ينادي ربه حتى ينثر ذرات العزاء ويزيل البغض والحقد من قلب عدوه. يقول: "عَدُوِي إِنْ رَنَوْتُ إِلَى السَّمَاءِ

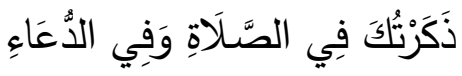


أثر التصوير البياني والتحسين البديعي فِ أداء معنى الصفح هٍُ الشعر المهجري: القروي

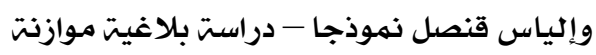

حوليت كليت اللغت العربيت بإيتاى البارود (العدد الثالث والثلاثون)

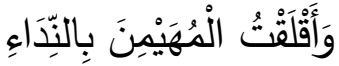

لِينْنُرُ بَعْضَ ذَرَّاتِ الْعَزَاءِ

بِقَلْبِكَ حَيْثُ طِيرَ الْبُغْضُ رَفَّا!...

و قد اتخذ قنصل في هذه المقطوعة من الكناية والاستعارة وسيلة تصويرية لإخراج معانيه وأفكاره.

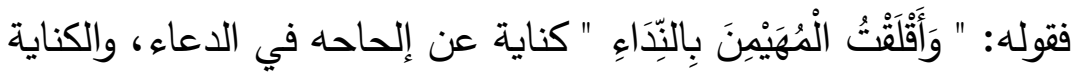
توحي برغبة قنصل القوية في إصلاح عدوه وإصراره على قبول دعائه.

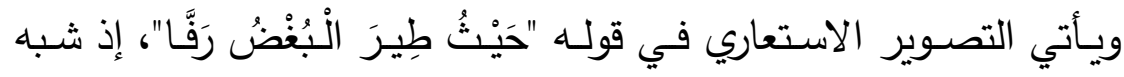
البغض والكراهية بطائر ، وحذفه وذكر شييًا من لوازمه وهو الطيران على سبيل الاستعارة المكنية، وهذه الاستعارة تبرز قيمة ذرات العزاء هذه وتأثيرها القوي في النفوس؛ إذ إنها تجعل البغض يخرج من القلب وكأنه سرب من الطير مُطسرَد مُزْعَج، ممـا يشعر بأثر تلك الذرات، فهي تمحو كل بغض وكراهية.

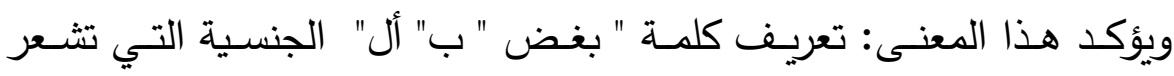
بانتهاء جميع البغض وما يتصل به من حقد وغل وحسد · وفي المقطوعة الحادية عشرة يستكمل كل شاعر فكرته بطريقته، فالقروي

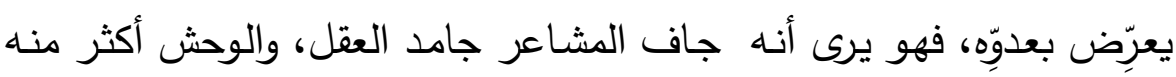
إيناسًا للغناء، وقلب الرياح أكثر منه خفقانًا، كذلك العشب أكثر منه تبسمًا، ثمداه يصل القروي إلى نتيجة مهمة؛ ألا وهي أن وصف العُبوس لا يتصف بـه إلا الدخان ووجه من رواء الحب قد جفَّ، فهو يقول: "رأيتُ الوحش يأنسُ للأغاني وصدرَ الريحِ يخفق بالحنانِ

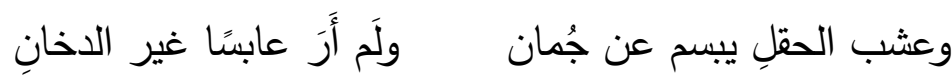

$$
\text { ووجاهِ من رُواءِ الحب جنّا" }
$$

وفي هذه المقطوعة يلجأ القروي إلى التصوير المتنوع ليُعبِّر عما بداخله

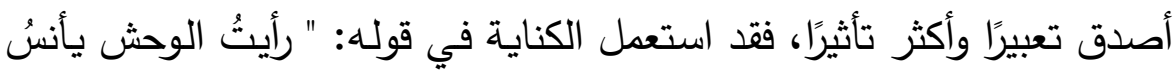


أثر التصوير البياني والتحسين البديعي فِ أداء معنى الصفح هٍُ الشعر المهجري: القروي

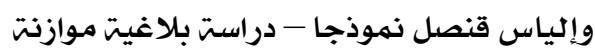

حوليت كليت اللغت العربيت بإيتاى البارود (العدد الثالث والثلاثون)

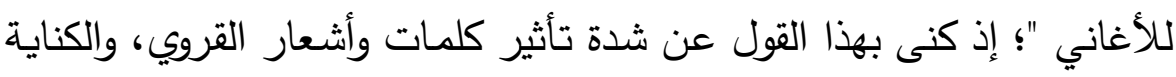
توحي بجمال كلمـات القروي وحسنها لدرجة أنها تؤثر في الوحوش، وكأنها

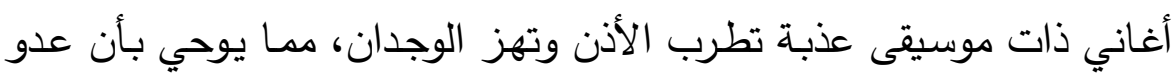
الثـاعر أقسى قلبًا من الوحش وأكثر منه غلظةً، فالوحوش قد تأثرت بأغانيه وأشعاره وروحه المتسامحة ووجهه الفرِح الطرِب، في حين أنه لم يستطع التأثير على أعدائه، مما يشعر بتحجر قلوبهم وجمود عقولهم وعدم الفائدة من محاولة

إصلاحهم.

وتطالعنا الاستعارة المكنية في قوله "وصدرَ الريحِ يخفق بالحنانِ"؛ إذ شبه الرياح بإنسان ثم حذفه وذكر شينًا من لوازمـه، وهو: الصدر - الخفقان، وهذا

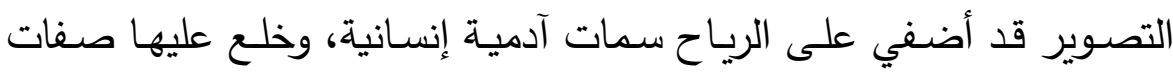
الأحياء ومنحها قلبًا نابضًا خافقًا، والاستعارة توحي بقسوة قلب عدو القروي

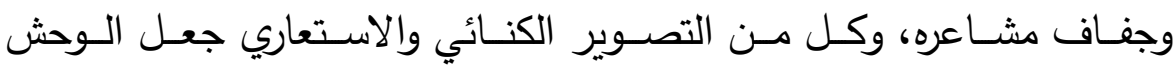

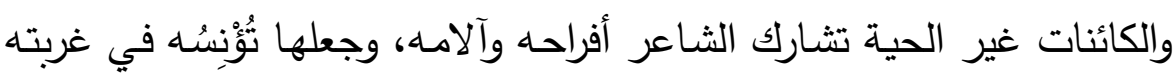

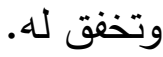

ويتعانق تصوير آخر مـع التصوير السابق في قوله " صدرَ الريحِ "؛ إذ إذ أذه

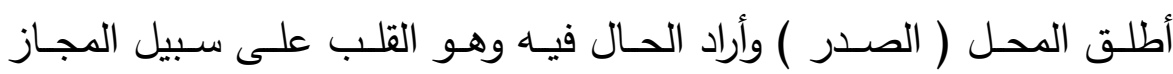
المرسل، والمجاز يوحي بأن الخفقان بالحنان قد تعدى القلب إلى الصدر ، وأن

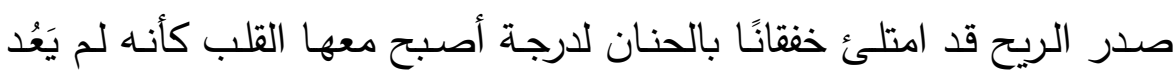
موجودًا، وقد تحول القلب في صدر الريح إلى الحنان، ويوضـح التصوير كذلك تآزُر الكائنات مع الشاعر وشعورها به. ويُتابع القروي تصويره في قوله: "وعشب الحقلِ يبسم عن جُمـان ولَّم أَرَ

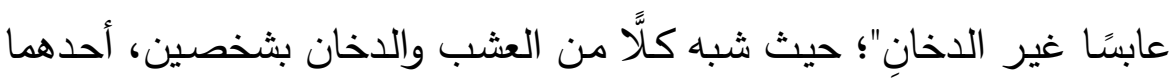
مبتســم والآخـر عـابس، وحذفهما وذكـر شـينًا مـن لوازمهمـا وهمـا الابتسـام والجمان، والعبُوس على سبيل الاستعارة المكنية، وهذا التصوير 
أثر التصوير البياني والتحسين البديعي فِ أداء معنى الصفح هٍُ الشعر المهجري: القروي

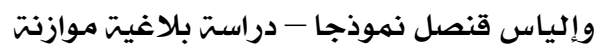

حوليت كليت اللغت العربيت بإيتاى البارود (العدد الثالث والثلاثون)

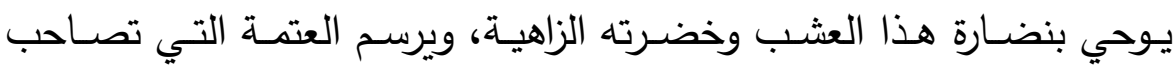
الاخان وتوجد أين ما وجد، ويوضح مدى الكآبة التي تخيم على المكان الذي ويدي يوجد با الدخان

والاستعارة هذه تتعـاون مـع التصـوير السـابق في الإشـعار بمشـاركة مظـاهر

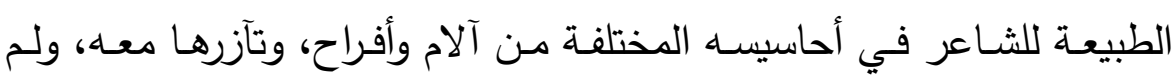

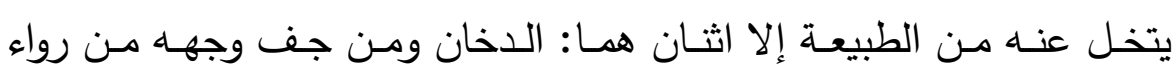

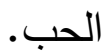

وأما إلياس قنصل في مقطوعته الحادية عشر فيبرز جانبًا من سماحته؛ إذ

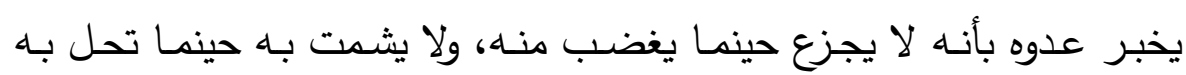

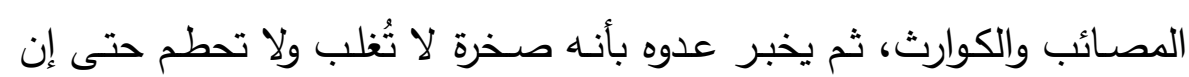
حملت مياه البحر جميعها؛ إذ يقول:

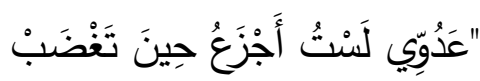

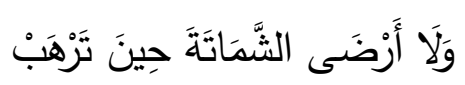

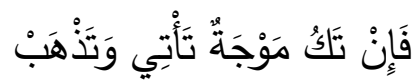

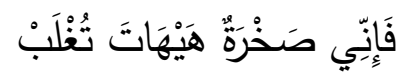

وَلَوْ حَمَلَتْ مِيَاةَ الْبَحْرِ حَتْفَا!.."

ويتتوع التصوير لاى قنصل في مقطوعته هذه بين الاستعارة والتشبيه.

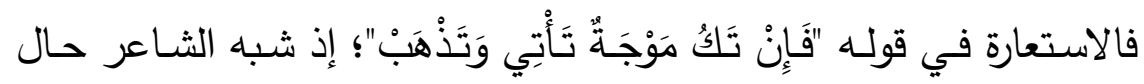
عدوه في عدم الاستقرار والتغيـر الدائم بموجـة تأتي وتذهب، على سبيل

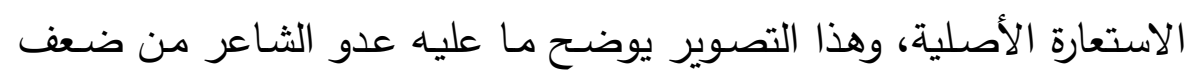
وعدم اتزان، ويكثف توتره وقلقه وهياجه الدائم وعدم استقراره.

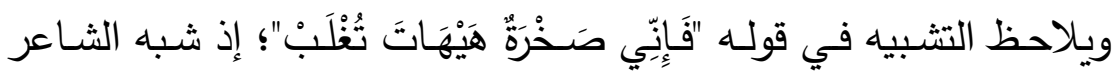
نفسـ بصـرة قويـة، وهذا التشبيه يوحي بقوة الثـاعر وتوضـح ثباته الانفعالي وقدرته على التحكم في انفعالاته وعدم غضباه بسهولة. 
أثر التصوير البياني والتحسين البديعي هِّ أداء معنى الصفح فِ الشعر المهجري: القروي

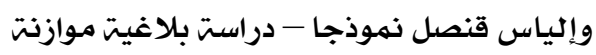

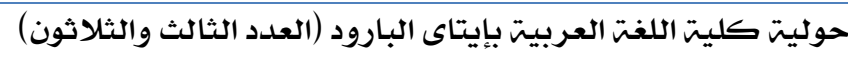

وفي المقطوعـة الثانيـة عشـرة يقدم الثـاعران النصـح والإرشـاد للأعداء؛

فالقروي ينصح عدوه بأن يعمل لآخرته لأن الحياة قصيرة وستتنهي في لحظة، وسيدخل الناس القبور المظلمة، إذ يقول:

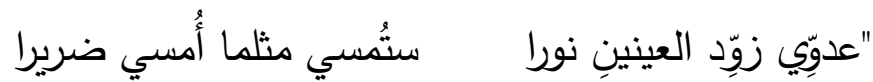

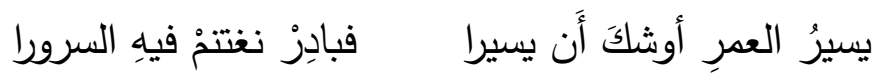

شقينا نصفَه فلنهنَ نصفا" أنَّنَ

فالقروي في مقطوعته هذه يعتمد في تصويره على الأسلوب الكنائي، كما

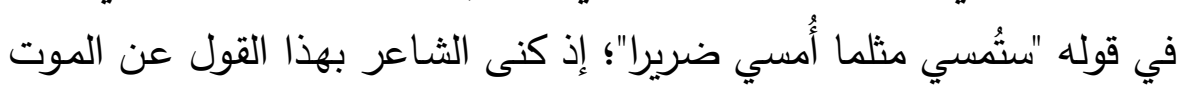
وظلمة القبر ، ففي القبر يصبح الإنسان عاجزًا تمامًا عن أداء أي فعل أو رؤية أي شيء، وهذه الكناية توحي بشدة ظلمة القبر ووحشته، مما يوجبب الاستعداد

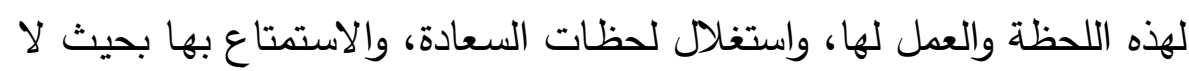
تتعارض هذه السعادة مـع المبادئ السامية والأخلاق العالية، فالحياة قصيرة وستنتهي في لحظة. وأمـا قنصل ففي مقطوعته الثانية عشر ينصـح عدوه بأن يزوره في بيته ويلجأ إليه عندما تتكاثر عليه الهموم ويتخلى عنه البشر، فسيجد عنده الراحة والأمان، يقول: النهان

"عَدُوِي إِنْ رَمَتْكَ يَذْ الْخُطُوبِ

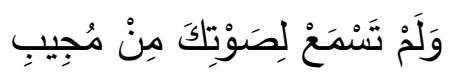

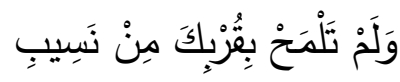

فَزْزْ بَيْتِي.... فَبِالصَّذْرِ الرَّحِيبِ

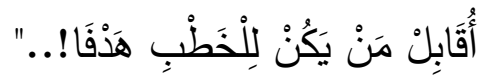

وقنصل في مقطوعته هذه قد اعتمد على التصوير الاستعاري.

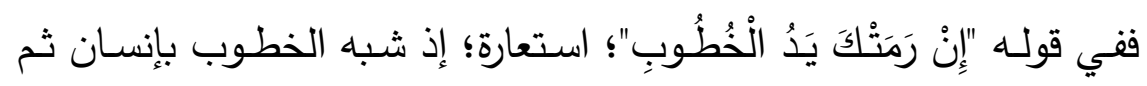
حذفه وذكر شينًا من لوازمه وهو اليد، على سبيل الاستعارة المكنية، والتصوير 
أثر التصوير البياني والتحسين البديعي فِ أداء معنى الصفح هٍُ الشعر المهجري: القروي

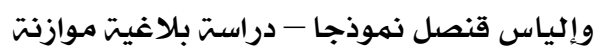

حوليت كليت اللغت العربيت بإيتاى البارود (العدد الثالث والثلاثون)

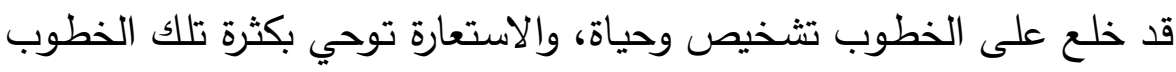
وشدتها، كما تشعر بضعف عدوه وقلة حيلته وتكالب المصائب عليه.

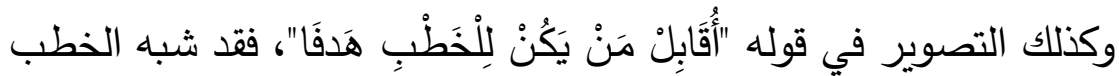

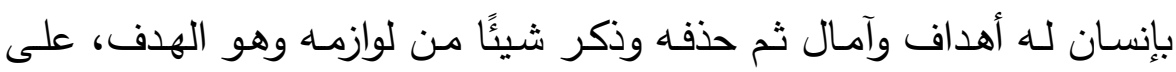
سبيل الاستعارة المكنية، وهذا التصوير يوحي بأن عدو الثاعر سيكون محط

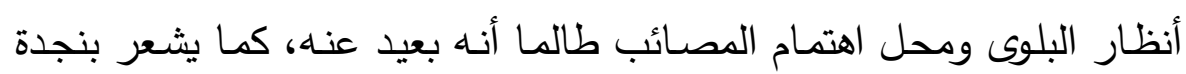
الثاعر وإغاثته للملهوف والتثريج عن المكروب، ويوضـح التصوير كذلك ثقة الثاعر الكبيرة بنفسه وافتخاره بها، فهو المتلقي لكل منكوب، والواقف بجانب كل بائس ومكروب، والتصوير كما نراه قد خلع على الخطوب لوازم إنسانية وصفات نفسية؛ إذ جعل للخطوب أيدي تفتك بعدوه وترمي بـه، وأهداف وآمال تتظظر تحقيقها.

وفي المقطوعتين الثالثة عشرة يكمل الثـاعران خطابهما مـع عدوِهما، إلا

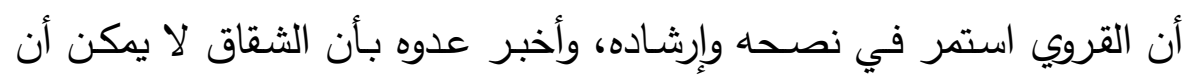

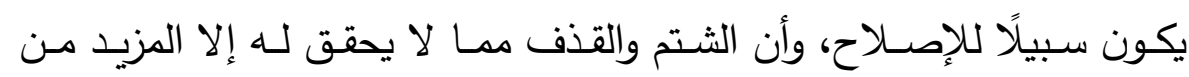
العداوة والبغض، يقول القروي:

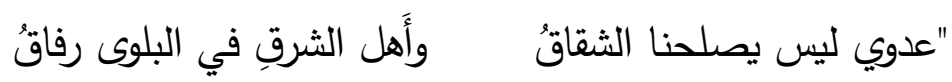

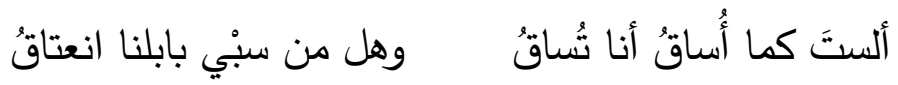
إذاذا أَوسعتني شتمًا وقذفا"

والقروي في مقطوعته هذه لم يسلك من سبل التصوير إلا سبيل الكناية،

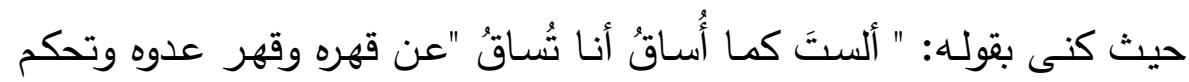
الغريب في مصيرهما، والتصوير يوضـح إلى أي مدى كان أهل الثرق كانوا يعانون من الظلم وتحكم الآخرين، وقد ساوت الكناية بين القروي وعدوه، فكما يعاني القروي يعاني عدوه؛ لذا يجب عليهما الاتحاد والتكاتف، وينسون مـا بينهما من ضغائن وأحقاد. 
أثر التصوير البياني والتحسين البديعي هِّ أداء معنى الصفح هٍِ الشعر المهجري: القروي

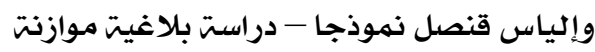

حوليت كليت اللغت العربيت بإيتاى البارود (العدد الثالث والثلاثون)

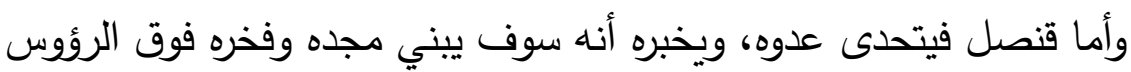

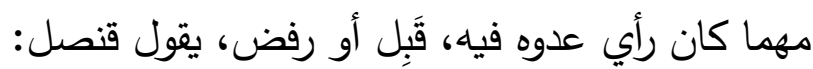

"عَدُوِي إِنْ أَرَدْتَ وَإِنْ أَبَيْتَا

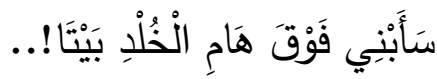

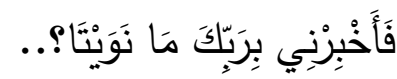

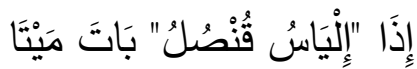

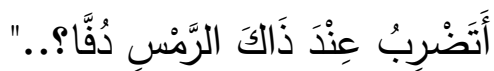

ويسلك قنصل الطريق التصويري نفسه الذي سلكه القروي في مقطوعته،

وهو التصوير الكنائي، فقد كنى بقوله: " سَأَبْنِي فَوْقَ هَامِ الْخُلْدِ بَيْتَا" عن تحديه

لعدوه وإصراره الثديد على إثبات ذاته ومقدرته، والكناية توحي بقوة الثاعر

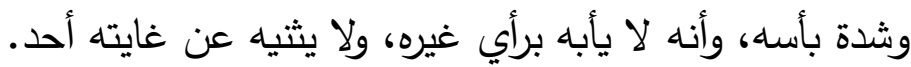

ويسـتمر الثـاعران في مقطوعتيهمـا الرابعـة عشـرة في تقـديم النصـح

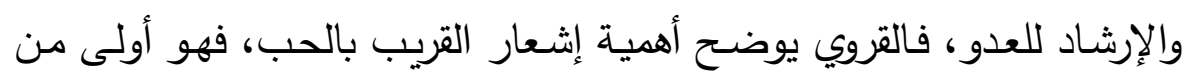
الغريب بذلك، يقول القروي:

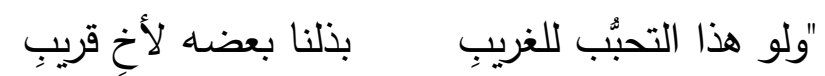

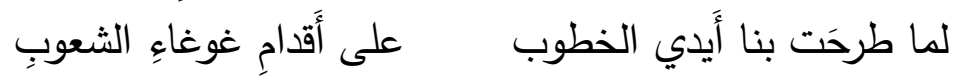

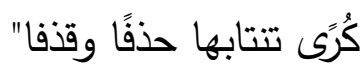

ولقد ركز القروي في مقطوعته هذه على التصـوير الاستعاري، كما في هري

قوله "الما طرحَت بنا أَيدي الخطوب"؛ إذ شبه الخطوب بإنسان، وحذفه وذكر هدهر شيئًا من لوازمه وهو "الطرح والأيدي"، والاستعارة جسدت الخطوب وشخَّصتها، وجعلتها حية نابضة ذات إرادة، وتركتنا نتخيلها تحمل وتطرح، والتصوير يبرز الضعف والهوان لدى الذين يُظهِرون ودهم للغريب ويهتمون به ويتحببون إليه، ويهملون أقرباءهم ويتجاهلونهم وهم أولى برعايتهم والعناية بهم. 
أثر التصوير البياني والتحسين البديعي فِ أداء معنى الصفح هٍُ الشعر المهجري: القروي

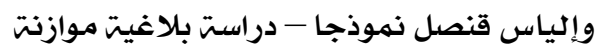

\section{حوليت كليت اللغت العربيت بإيتاى البارود (العدد الثالث والثلاثون)}

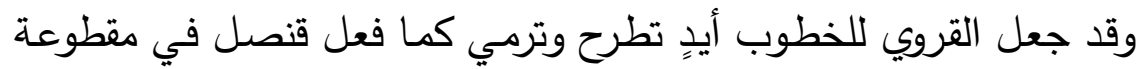
سابقة(') إلا أن قنصل كما رأينا قد جعل عدوه هو من ترمي به أيدي الخطوب لطرجي

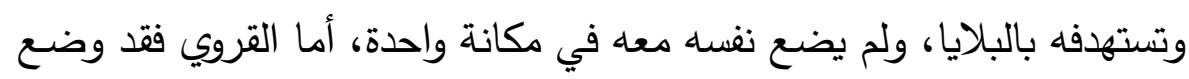

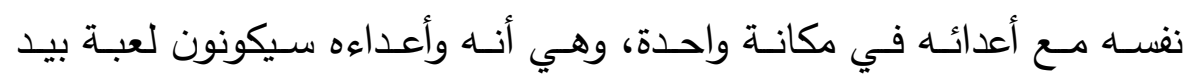
الخطوب للو لم يتحدوا ويتكاتفوا، ويجعلوا حبهم للقريب ويتوقفوا عن بذلـه للغريب، مما يوحي برهافة حس القروي وحبه الثديد لقومهه وسماحته المفرطة

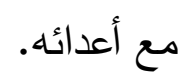

وتتعانق الاستعارة الأصلية مـع التصـوير السابق في قوله "كُرَى تنتابها حذفًا وقذفا"؛ إذ شبه الثـاعر نفسه وإخوانه المعادين لله بالكرى التي تتلاعب الإدي

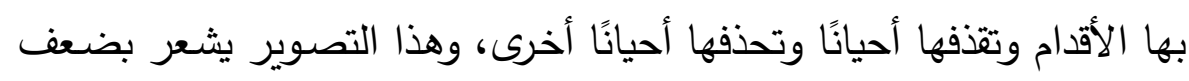
هؤلاء المتفرقين وتفككهم وعدم تكاتفهم وترابطهم، وهوان أمرهم في عين غوغاء الثعوب التي تتلاعب بهم وتتحكم في مصائرهم ومقدراتهم، وهو الأمر الذي وهم وهري يحذر منه القروي، .

وأمسا قنصل في مقطوعته الرابعة عشر فينصح عدوه بأن يحلم بصفو العيش كما يحلم هو، ويحاول أن يكون سعيدًا حتى لو كان واهمًا، ويبتسم حتى إن خدعته الأماني، فيقول: "عَدُوِي لَ أُرِيدُكَكَ غَيْرَ سَالِّْ

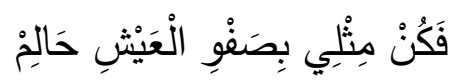

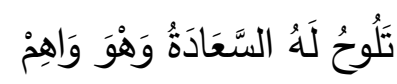

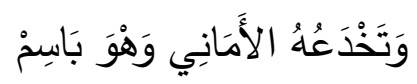

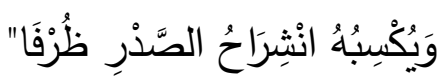

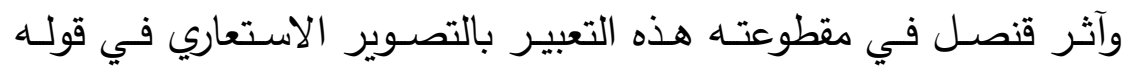

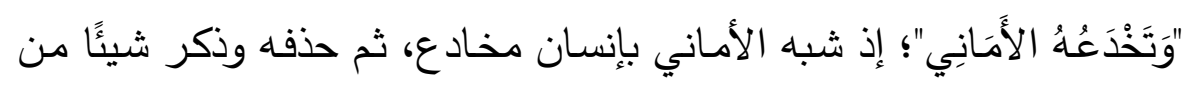


أثر التصوير البياني والتحسين البديعي فِ أداء معنى الصفح هٍُ الشعر المهجري: القروي

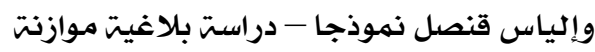

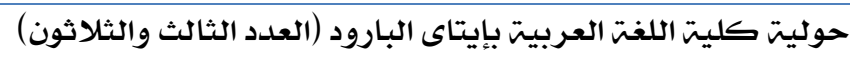

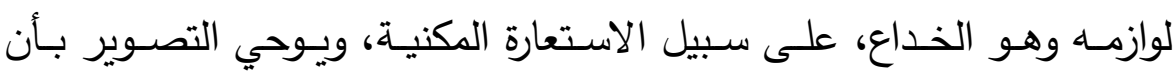
الأماني تبذل جهدها وتتعب حالها حتى تتجح في إغراء الشخص وخداعه وأن الإنسان كثرّر ما تغره الأمنيات وتخدعه الأحلام، حينها ينساق لها ويلهث وراءها باحثًا عن السعادة الوهمية مهما كلفه الأمر .

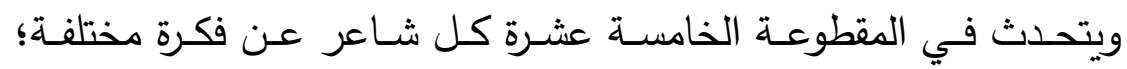
فالقروي يبين أن القرية بها الراحة وهدوء النفس لدَن كوَتْه الضغائن والأحقاد، إذ بها الخضـرة والمـاء اللذان يريحـان النفس ويهدآن الأعصـاب، فلربمـا يعود الحاقد منها سليم القلب محبَّا لإخوانه؛ إذ يقول:

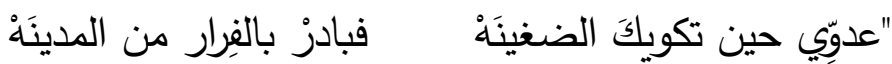

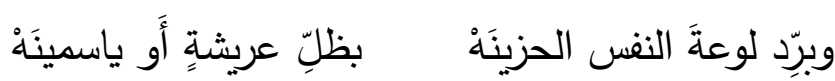

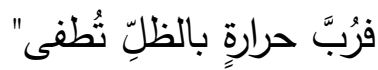
وقد كان التصوير في مقطوعة القروي هذه عن طريق الاستعارة والكناية.

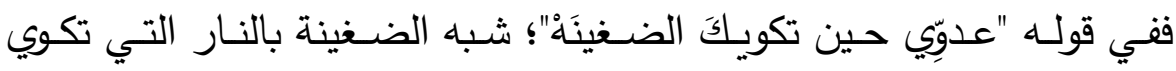
وتحـرق، وحذفها وذكر لازم مـن لوازمها وهـو الكيّ، على سـبيل الاستعارة

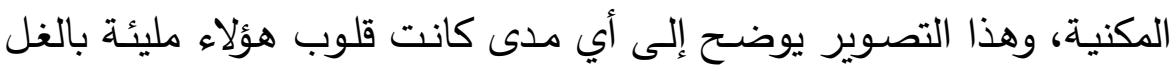
والحقد والغيظ تجاه الشاعر ، وأن هذه المشاعر بلغت من الثدئ الثدة والقوة بحيث تكوي حاملها قبل غيره وتحرقه. ويتضح التصوير كذلك في قوله "وبرِّد لوعةَ النفس الحزبنَةْ بظلِّ عريشةٍ

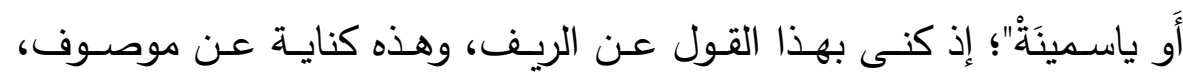

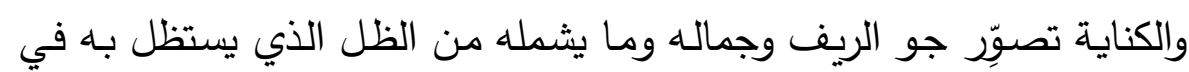
وقت الهاجرة والأشجار الوارفة والروائح العطرة المنبعثة من الورود والأزهار النضرة المبهجة، ولا أجمل من هذا الجو الخلاب الساحر • 
أثر التصوير البياني والتحسين البديعي هِّ أداء معنى الصفح فِ الشعر المهجري: القروي

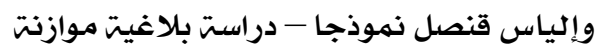

حوليت كليت اللغت العربيت بإيتاى البارود (العدد الثالث والثلاثون)

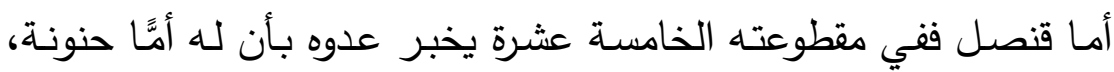

تقضي الليل كله قلقةً عليه حزينةًَ، وهو لا يريد أن يقلقها أو يحرمها الهدوء

والسكينة أو يروع أمنها بالحقد وما أشبهه، يقول:

"عَدُوِي إِنَّ لِي أُمََّّا حَنُونَهْ

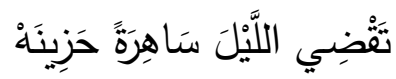

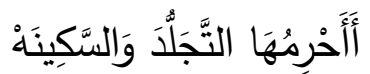

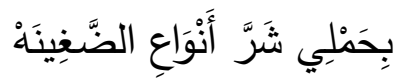

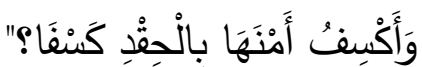

وقد اتخذ قنصل في مقطوعته هذه من التصوير الكنائي والاستعاري وسيلة للتعبير عن مكنون أفكاره، ومخزون معانيه.

ومن ذلك: الكناية في قوله: " تَقْضِي اللَّيْلَ سَاهِرَةً حَزِينَهْ " فقد كنى بهذا القول عن قلق أمسه الشديد وتوترها، وهذه الكنايـة توضـح مدى انزعاج أمسه وخوفها عليه من أعدائه.

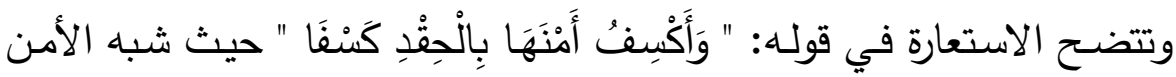

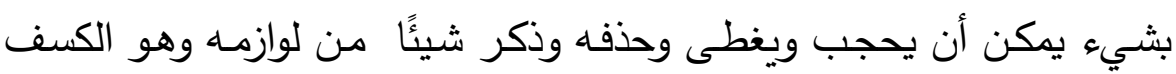
على سبيل الاستعارة المكنيـة، وقد جعل التصـوير مـن الحقد غطـاءً يستر

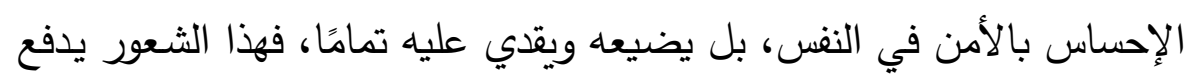
بصاحبه لإيذاء من يحقد عليه وتدميره، وهذا ما كانت تخشاه أم قنصل. ويخبَرَنا القروي في مقطوعته السادسـة عشرة بأن فيض المحاسن إذا راغَ

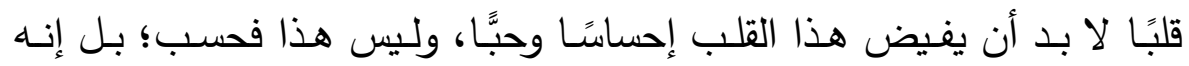

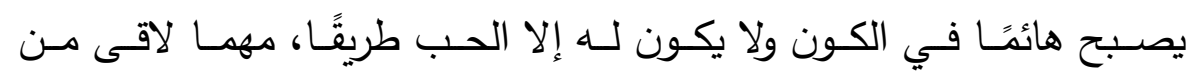
المحبوب، حتى لو لاقى منه حتفه، إذ يقول:

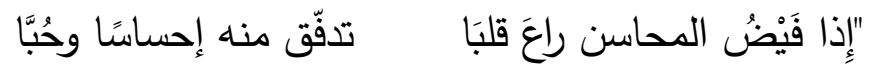
وأصبحَ هائمًا بالكونِ صَبَّا فليس يُطيقُ إلَّا أَنْ يُحسَّا 
أثر التصوير البياني والتحسين البديعي هِّ أداء معنى الصفح هٍِ الشعر المهجري: القروي

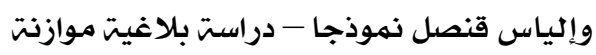

حوليت كليت اللغت العربيت بإيتاى البارود (العدد الثالث والثلاثون)

ولو لاقى من المحبوبِ حتفا"

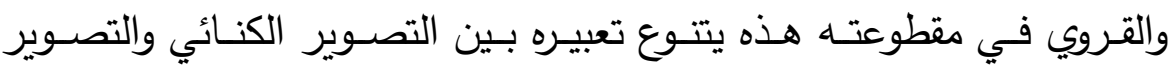

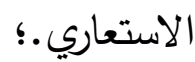

فقد كنى بقولـهـ "إذذا فَيْضُ المحاسن راعَ قلبَا " عن جمال المحبوب وكثثرة محاسنه، وهذه الكناية تشعر بإعجاب الحبيب الثديد بحبيبه وأنـه لا يرى منه لهاع إلا المحاسن، ولا يمكن أن يرى منه عيبًا.

وتتعـانق مـع الكنايـة السـابقة الاستعارة في قولـه: " تدفّق منـه إحساسًا وحُبَّا " " حيث شبه الإحساس العظيم والحب بماءٍ يتدفق وحذفه وذكر شينًا من لوازمـه

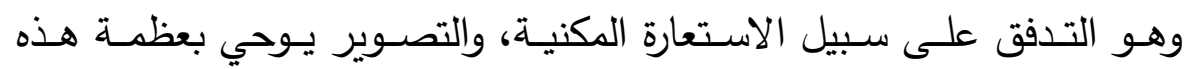

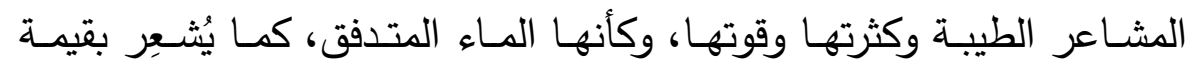

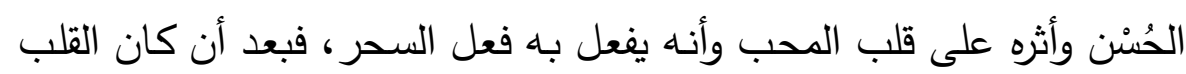
جافًا من المشاعر والأحاسيس أصبح كنهرٍ يتدفق بمشاعر حب دافئة تغمره وتحميه من كل المشاعر السلبية من حقد وغل وحسد. ويعود القروي إلى الكناية في نفس المقطوعة مرة أخرى، حيث كنَّى بقوله "ولو

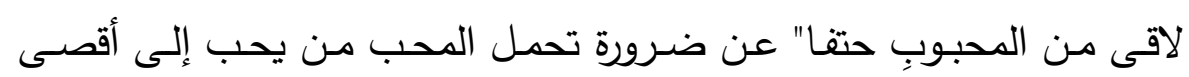

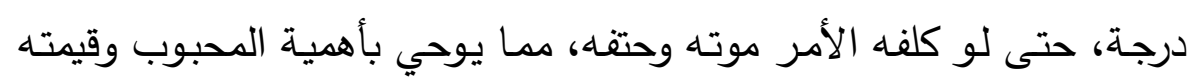
عند المحب. وأمسا إلياس قنصل ففي مقطوعته السادسة عشرة يستكمل حديثه عن أمسه

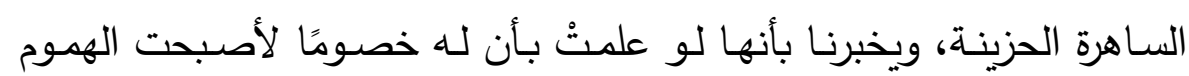
والغموم لها رفقاء، يقول قنصل:

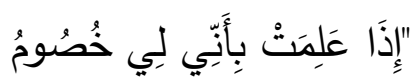

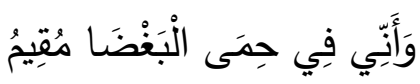

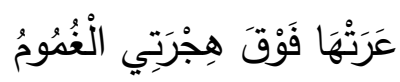

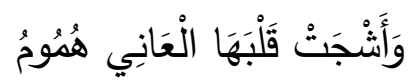


أثر التصوير البياني والتحسين البديعي هِّ أداء معنى الصفح فِ الشعر المهجري: القروي

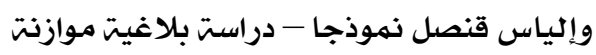

حوليت كليت اللغت العربيت بإيتاى البارود (العدد الثالث والثلاثون)

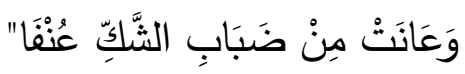

وفي مقطوعة قنصل هذه نجده يلجأ إلى التصوير عن طريق الاستعارة تارة

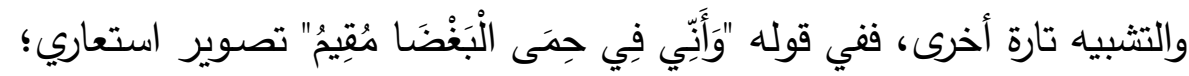
إذ شبه البغض بشخص قوي يستطيع حماية نفسه وغيره، ثم حذف المشبه به وذكر شـينًا مـن لوازمـه، وهو الحمايـة، على سبيل الاستعارة المكنيـة، وهذه الاستعارة توحي بأن شعور البغض يمكن أن يسيطر على الشخص ويجعل تصرفاته رهن أمره وإشارته، ويتحكم فيه ويوجهه؛ إذ يتصرف صساحب الثعور وفق إرادته، فيؤذي غيره وهو لا يشعر •

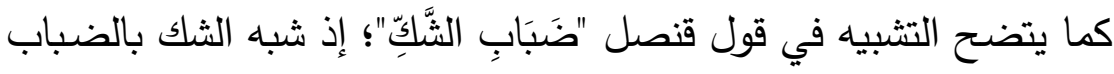
تثبيهًا بليغًا، وهذا التثبيه يرسم السواد الذي يخيم على حيات الثاك، ويوضـح النظرة الضبابية التي تتحكم في تصرفات الرجل الذي يدب في قلبه الثك، وأنه يكون في حالة من الغموض والحيرة والقلق، وهذه الأشياء تجعل صاحبها غير مطمئن أو مستقر •

وفي المقطوعة السابعة عشرة يهجو كلا الثاعرين عدوَّهما إلا أن القروي يهجو عدوه بشكل واضح وصريح؛ حيث يصفه بثلاث أشياء: عوسجة الحديقة - شوك الورد - مرارة الخمر، يقول القروي:

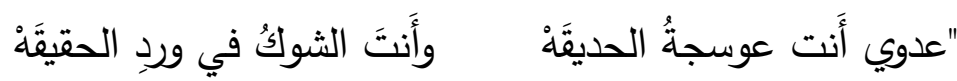

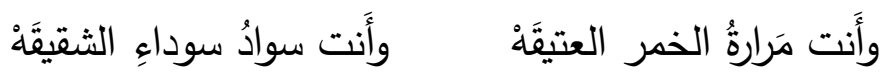

تزيد جمالها لُطفًا وظَرفا"

بتأمل مقطوعة القروي هذه يلاحَظ أن التشبيه كان هو الفن التصـويري الأكثر استخدامًا في تعبيرات المقطوعة، فبه استعان القروي على إخراج ما

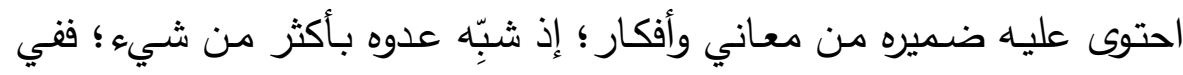


أثر التصوير البياني والتحسين البديعي هِّ أداء معنى الصفح مِّ الشعر المهجري: القروي

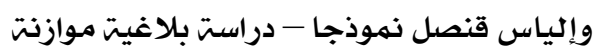

حوليت كليت اللغت العربيت بإيتاى البارود (العدد الثالث والثلاثون)

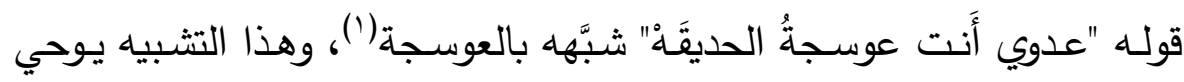

بسوء هذا العدو وخبثه، فهو شخص مراوغ شائك يصعب التعامل معه.

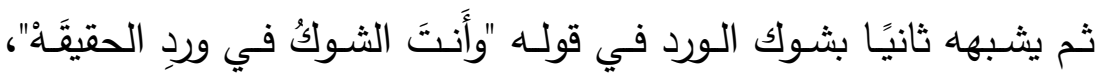

والتشبيه هذا يشعر بكثرة إيذاء هذا العدو للشاعر ؛ فالشاعر يحب الحياة ويريد الاستمتاع بها، إلا أن عدوّه يُصِِّب عليه ذلك، بل إنه يفسد عليه الحياة، لكنه يتحمله كما يتحمل أشواك الورد من يستمتع به؛.

ويتعـانق مـع التشـبيهين السـابقين التصـوير الاسـتعاري فـي قولـه "وردِ

الحقيقَه"؛ إذ شبه الحقيقة بحديقة، وحذفها وذكر شينًا من لوازمها،وهو الورد، على سبيل الاستعارة المكنية، وهذا التصوير يوحي بجمال الحقيقة وأنها التي يجب أن تعلو فوق كل شيء، ويُتحَمل من أجلها كل شيء كما يؤكد المعنى ئى ئه

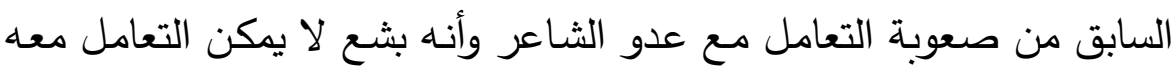
وأن بشاعته هذه تصيب كل شيء حوله.

ثم يشبِّه القروي عدوه تشبيهًا ثالثًا ورابعًا بمـرارة الخمـر العتيقـة وسـواد

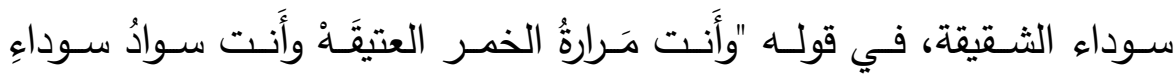

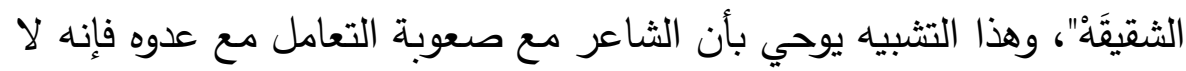

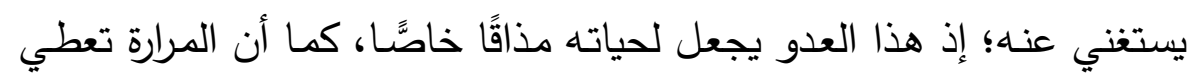
الخمر مذاقًا أطيب، والسواد يعطي لسوداء الثقيقة منظرًا أجمل وألطف.

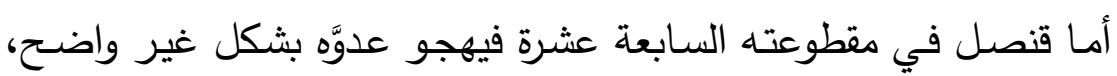
بثكل فيه تورية يفهم من خلال ذكره للصفات يجب التحلي بها من وجهة نظره وهـي: الحريـة،وما يترتب عليهـا مـن نقـاء وصـفاء، كمـا يـرى أن الإنسـان المشاغب مهما أخفي أمره فلا بد من كثفه في يوم من الأيام، يقول قنصل:

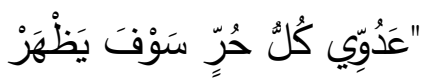

(1)جنس نبات شائك من الفصيلة الباذنجية، له ثمرٌ مدوَّر كأنَّهُ خَرَز العقيق، ينظر : لسان

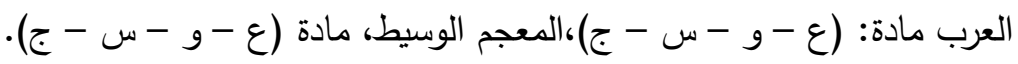


أثر التصوير البياني والتحسين البديعي هِّ أداء معنى الصفح بِّ الشعر المهجري: القروي

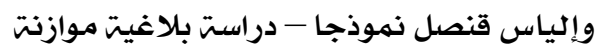

حوليت كليت اللغت العربيت بإيتاى البارود (العدد الثالث والثلاثون)

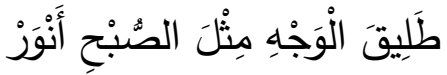

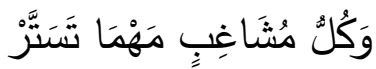

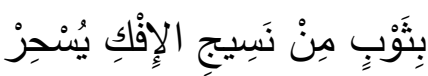

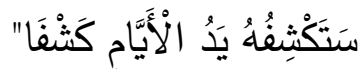

ويتتوع التصوير في مقطوعة قنصل هذه، بين التشبيه والاستعارة، فالتشبيه

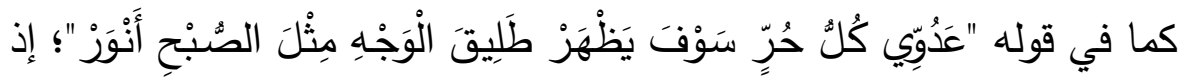
شبه وجه الحر ذي المقاصد والأهداف الواضحة بالصبح، وهذا التشبيه يشعر بجمال وجـه الحر وإشراقه، كما يوحي بوضوح نواياه وثقته بنفسه وبتصرفاته

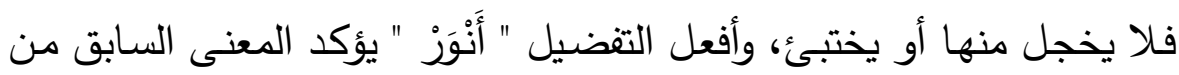
الوضوح وعدم الضبابية.

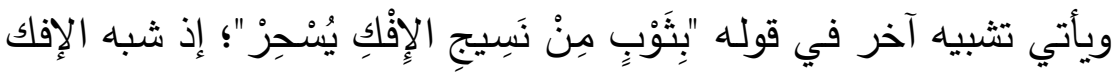
بنسيج تشبيهًا بليغًا، وهذا التشبيه يشعر بتفاقم الإفك وإحاطته بالمكان وانتشاره بشكل كبير ، كما يوحي بإحكام الإفلك وأنـه مُحْبَك متقن لدرجة لا يمكن معها

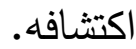

ثم تأتي الاستعارة في قول قنصل "سَتَكْثِفُفُهُ يَدُ الْأَيَّامِ كَثْفَا"؛ إذ شبه الأيام

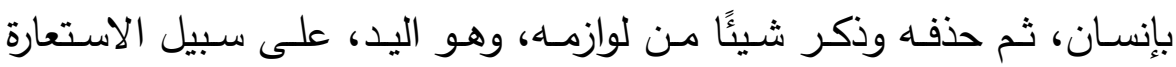

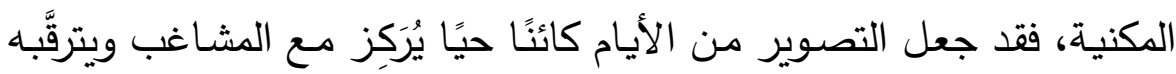

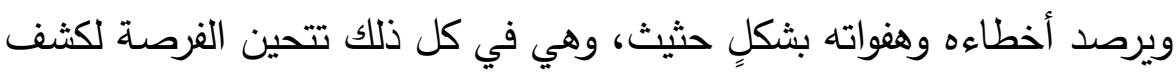

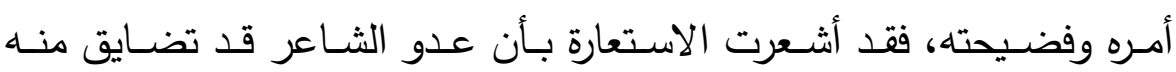
وتضرر كل مـا في الكون، حتى الأيام ستنقلب عليه وتتعاون مـ الزمن في كثف ستره، وتوحي الاستعارة كذلك بأن الزمن مهما طال على المتستر لا بد أن يُظهره ويكشفه، ويفضح أمره. 
أثر التصوير البياني والتحسين البديعي هِّ أداء معنى الصفح مِّ الشعر المهجري: القروي

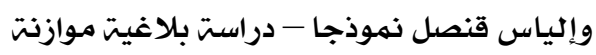

حوليت كليت اللغت العربيت بإيتاى البارود (العدد الثالث والثلاثون)

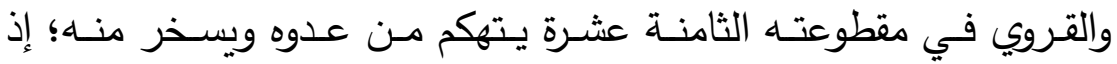

يخاطب عدوه ويوبخه على تدخُّه الزائد في حياته، فها هو يرجو منه أن تكون لئن

عينه في قلبه ليصلح ما استتر في قلبه من الفساد، يقول القروي

"عدوّي ليت عينَك في فؤادي لتُصلحَ فيه مستترَ الفسادِ

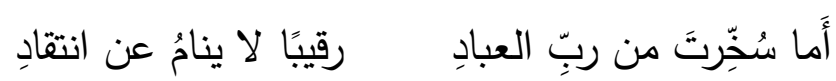

ولا يغضي عن الهغواتِ طرفا"

ويلاحَظ أن القروي في مقطوعته هذه قد عبر بالأسلوب الكنائي؛ إذ كنَّى

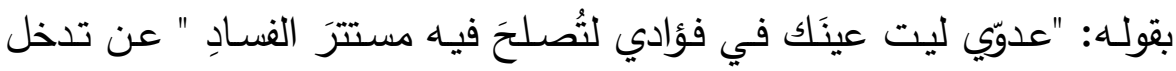
عدوه الزائد في شئون حياته بشكل مستفز ، وهذا التصوير يوضح ضيق القروي الثديد من تصرفات عدوه، ويشعر كذلك بتهكم القروي منهه ومن أفعاله، وقد

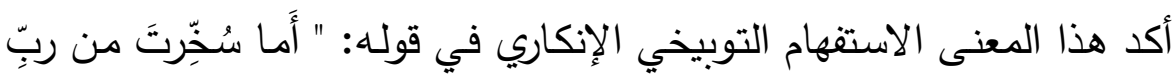

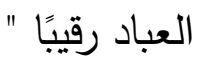

ثم كنَّى بقوله "ولا يغضـي عن الهفواتِ طرفا" عن تركيز عدوه الثديد في كل هفواته وتصيده الأخطاء له، وهذا التصوير يكثف عن عن انزعاج القروي من لن عدوه ودجره الثديد منه، ويوضتح ملاحقة ومتابعة عدو القروي الحثيثة له. وأما قنصل في مقطوعته الثامنة عشرة فيعاني مثل معاناة القروي من عدوه وتدخله في حياته؛ إذ يخبرنا بأنه لم يسلم أحد من نقده، وكان نقده كالسهام، أصساب بسمه كل من عرفه حتى الأعمى والأصم، وقد أحدث وقع هذا النقد قَالًا وَخَلْفَا، يقول قنصل: لِّل

"عَدُوِي قَذْ ذَرَفْتُ الََّمْحَ قَدْمَا

وَكُنْتُ أَرَى بَيَاضَ الْعَيْشِ شُؤَّْْا

وَكَمْ أَطْلَقَتُ يَوْمَ النَّقْْدِ سَهْهَا

أَصَابَ بِسمِِّهِ الأَعْتَى الأَصَمَّا

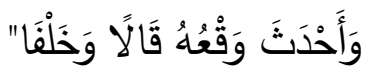


أثر التصوير البياني والتحسين البديعي فِ أداء معنى الصفح هٍُ الشعر المهجري: القروي

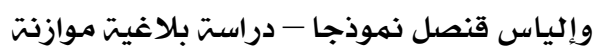

حوليت كليت اللغت العربيت بإيتاى البارود (العدد الثالث والثلاثون)

وقنصل في مقطوعته هذه يتنوع تصويره بين الاستعارة والكناية، فالاستعارة

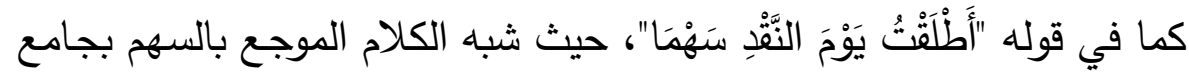
الألم في كل ثم استعير السهم للكلام الموجع على سبيل الاستعارة الأصلية، وهذا التصوير يوحي بشدة تأثير النقد على نفس الذي يوجهه لـه النقد وقوَّته، وأنه كثير الإيجاع عظيم الإيلام، فقد جعلت الاستعارة من النقد اللاذع سهئًا موجعًا، بل في كثير من الأحيان قاتلًا.

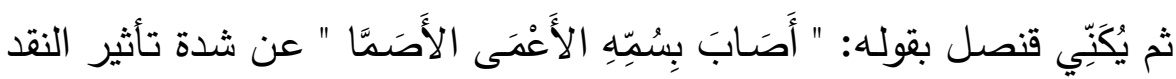

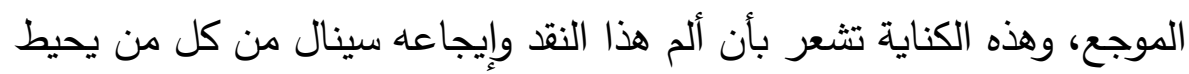

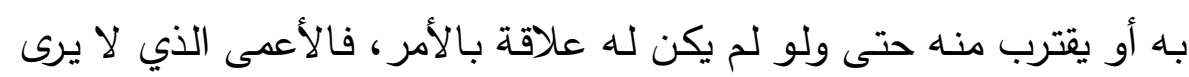

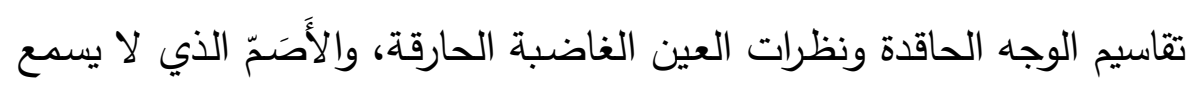
الكلمات اللاذعة والنبرات القاسية سيؤثر فيهما الألم وينال منهما الوجع؛ مما لوال يوحي بقسوة هذا الكلام وشدة وقعه.

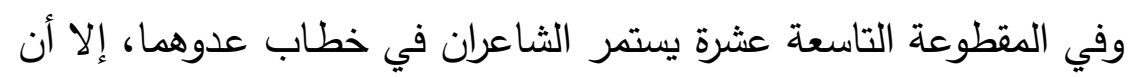
القروي في مقطوعته قد قرر أن يترك لوم عدوه وهجائه، وينتقل إلى الدعاء لله

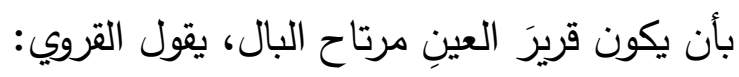

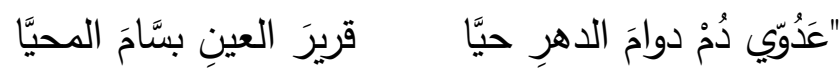

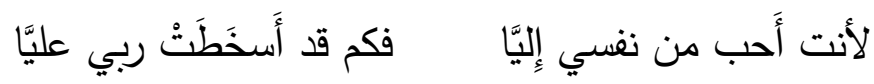
وكم نبّهتها حتى تكُّفا"

وقد اعتمد القروي في تصويره في مقطوعته هذه على الفن الكنائي، كما في قوله: " قريرَ العينِ" فقد كنى بهذا القول عن الطمأنينة وراحة البال التي يطلبها لعدوه. (- إ.

وكذلك كنى بقوله: "بسَّامَ المحيَّا " عن هناء العيش والسعادة التي يتمناها لعدوه

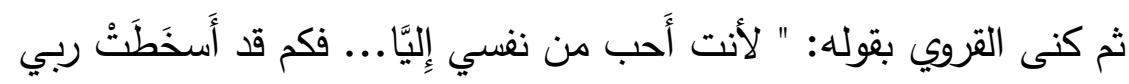

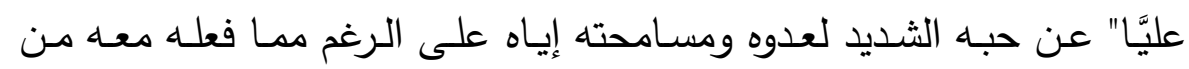


أثر التصوير البياني والتحسين البديعي هِّ أداء معنى الصفح هٍِ الشعر المهجري: القروي

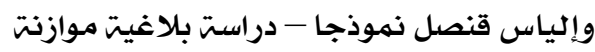

حوليت كليت اللغت العربيت بإيتاى البارود (العدد الثالث والثلاثون)

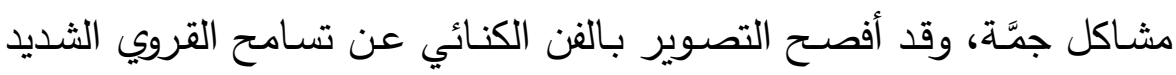

وصفحه المطلق.

وقنصـل في مقطوعتـه التاسـعة عشـرة مـا زال في حالـة مـن الاعتراف بأخطائهه في الماضـي، فيقر بأنـه كان مغرورًا في نفسـه، ومـع هذا فقد كان يشعر بمرارة العيش، فشعوره ب التميز والغرور لـم يسبب لـه السعادة، يقول

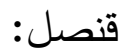

"عَدُوِي كُنْتُ مَفْرُورًا بِنَفْسِي

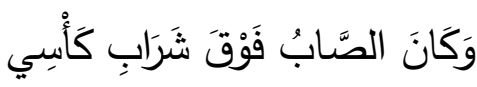

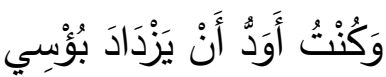

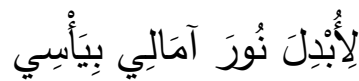

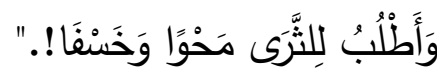

وفي مقطوعة قنصل هذه نجد أن أسلوبه التصويري يتنوع بين الكناية والتشبيه،

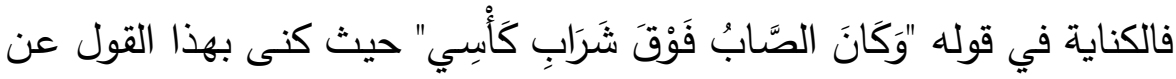
صعوبة الحياة وشقاء العيش، وهذه الكنايـة تصـور بدقة إلى أي مدى كان يعاني قنصل، وتبرز صعوبة حياته قبل مسامحته عدوَّه وصفحه عنه.

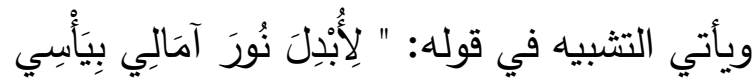

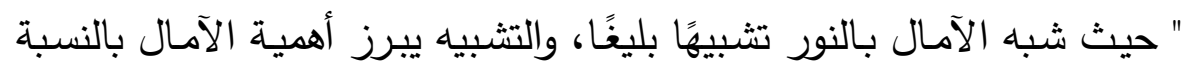

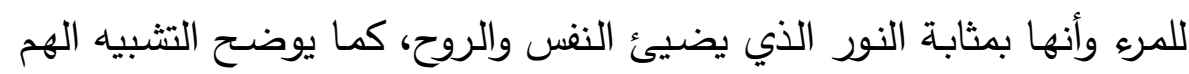
الذي كان يعيش فيه قنصل، ويشعر برغبته القوية في التخلص من هذا اليأس ولرون

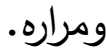

ويكمل الثاعران في المقطوعة العشرين فكرتهما، فالقروي يخبر عدوه بأن نفسه هي عدوه اللدود، وهي النفس المتقدة المشتعلة بداخله دائمًا، ثم يطلب منه مؤاخاة الناس والتصالح معهم، وقتل عدوه الأكبر الذي بداخله، إذ يقول: "عدوُك يا عدوي من تَوارى بصدرِكَ مُوقدًا بحشاكَ نارا 
أثر التصوير البياني والتحسين البديعي هِّ أداء معنى الصفح هٍِ الشعر المهجري: القروي

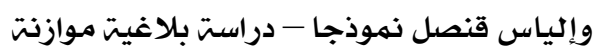

حوليت كليت اللغت العربيت بإيتاى البارود (العدد الثالث والثلاثون)

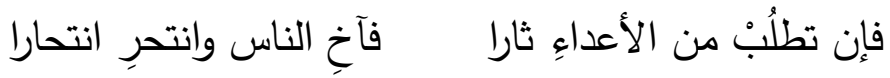

فأَعداهم بثوبك قد تخفّى"

وقد كان لفن الكنايـة كذلك الأثر الواضـح في الكثف عن غور المعنى

الذي يقصده في مقطوعته هذه، إذ كنى بقولـه "عدوُّك يا عدوي من تَوارى

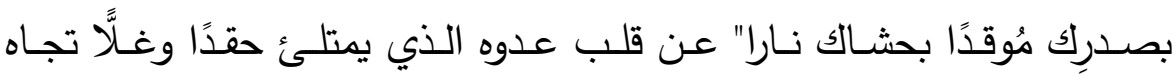
الآخرين، ويرجو لهم الإيذاء في كل لحظة، وهذه الكناية تصور قبح صـاحب

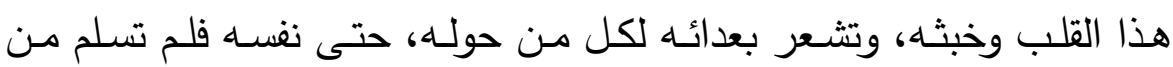
عدائه.

وتتعانق الاستعارة مع الكناية السابقة في قوله " نارا "؛؛ إذ شبه قلب عدوه

بنار موقدة، ثم استعيرت النار لهذا القلب على سبيل الاستعارة الأصلية، وهذه الاستعارة تصور قلب عدو الثاعر وما فيه من غليان دائم وما يكنُّه من حقد

وغل وحسد، وما يحمله من طاقة سلبية تدمر نفسه قبل الآخرين.

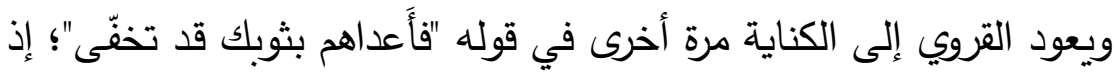
كنى بهذا القول عن عدوِه، وهذه الكنايـة كناية عن نسبة، فقد جعل القروي العداوة الثديدة في ثوب عدوه وذلك تأكيدًا لعداوته غير المحدودة، والكناية

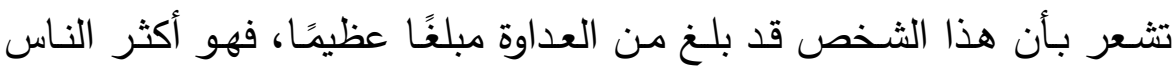
بغضًا وكرهًا، وحقدًا وغلًًا؛ إذ ليست في قلبه ذرة من المحبة أو المودة

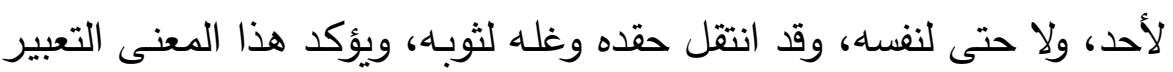
بأفعل التفضيل "أعداهه"، الذي يوحي بأنه أكثر الناس عداوةً.

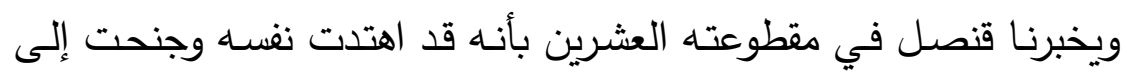

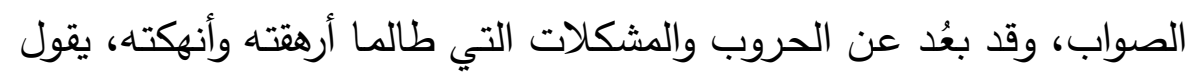

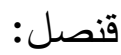

$$
\begin{aligned}
& \text { "وَلَكَنِّي جَنَحْتُ إلَّى الصََّوَابٍ }
\end{aligned}
$$

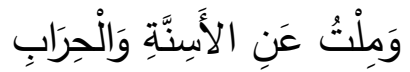


أثر التصوير البياني والتحسين البديعي هِّ أداء معنى الصفح هٍِ الشعر المهجري: القروي

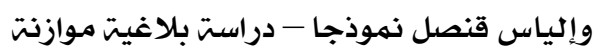

حوليت كليت اللغت العربيت بإيتاى البارود (العدد الثالث والثلاثون)

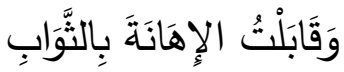

فَخَفَّتُ شِقُْتَي.... وَنَأَى عَذَابِي

وَعَفَّتْ مَوَاقِعِي وَازْدَدْتُ عَطْفَا!...

إن هذه المقطوعة لقنصل يتجلى فيها دور الكناية بشكل واضـح؛ إذ كانت

هي الفن التصويري الرائد في الكثف عن خبايا أفكار الثاعر التي تضمنتها

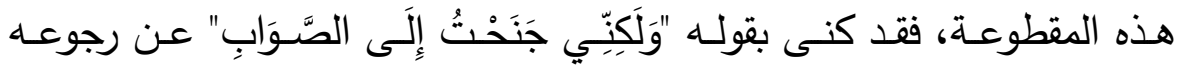
للصـواب وبعده عن الخطأ، وهذه الكنايـة تصـور إلى أي مدى كان قنصل فيل صادقًا مع نفسه، وأنه من الممكن أن يعترف بخطئه.

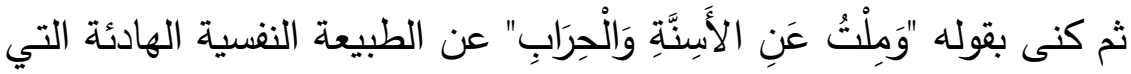
أصبح عليها بعد مسامحته عدوه؛ إذ أصبح يكره الحرب وكل ما يتصل بها، وهذا التصوير يثعر بالطمأنينة التي أصبحت تحيط بقنصل وتغمره، ويوحي كذلك بسعادته الغامرة وفرحته الثديدة بما وصل إليه من تسامح وصفح.

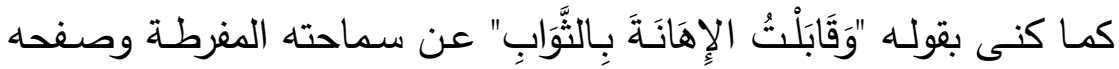
الثديد، والكناية توحي باتساع صدره ورحابة فكره.

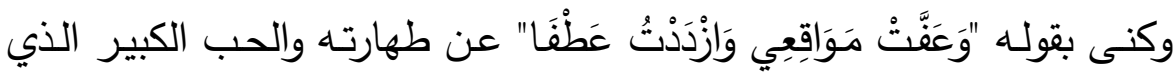
ملأ قلبه، وهذا التصوير يوحي بأن قنصل بعد السماحة والصفح اللذين امتلأ

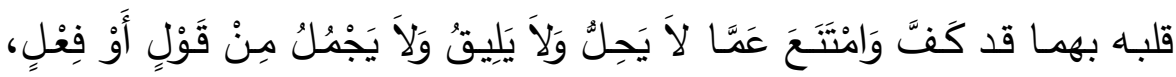

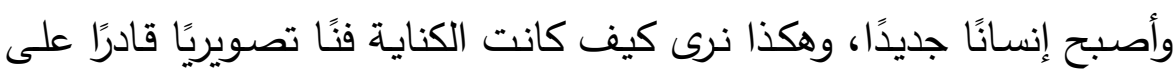
منح المعنى حياة، وإعطاء روحًا تأثيريَّةً للألفاظ. ويُكمِل الثـاعران في المقطوعـة الحاديـة والعشرين حديثهما مـع عدوِهما، وإن كان حديثهما مختلفًا هذه المرة؛ فالقروي يخبر عدوه بأن ما هو فيه وهمٌ كبير قد صنعه لنفسه من خياله، فليس هناك أحد يكرهه أو يريد إيذاءه كما هو هو هون هون متخيل، يقول القروي: - مت "عدوِي أَنت في حُلمٍ مخيفِ 
أثر التصوير البياني والتحسين البديعي هِّ أداء معنى الصفح هٍِ الشعر المهجري: القروي

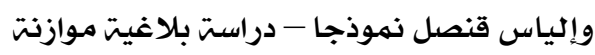

حوليت كليت اللغت العربيت بإيتاى البارود (العدد الثالث والثلاثون)

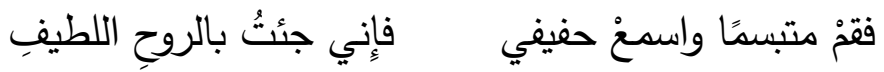

يرفتُ عليك عند النوم رفّا"

ففـي مقطوعـة القـروي هـذه يتــوع أسـلوبه التصـويري بـين فنَّي الكنايــة

والاستعارة، كلٌّ في مكانها يؤدي المعنى ويبرزه.

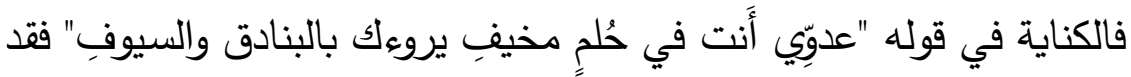

كنى بهذا القول عن الوهم الذي يعيشـه عدو الثاعر من تحامل الناس عليه

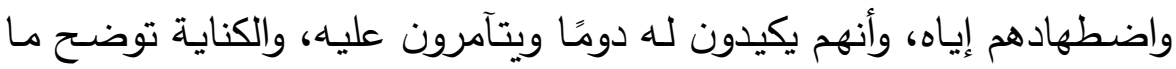

عليه عدو الثاعر من قلق واضطراب دائمين بسبب إيذائه المستمر للآخرين.

وتأتي الاستعارة في قوله " حفيفي"؛ إذ شبه الثاعر نفسه بأوراق الثجر

الرقيقة، ثم حذفها وذكر شيئًا من لوازمها، وهو الحفيف، على سبيل الاستعارة

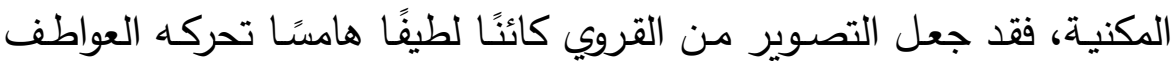
الطيبة كالمحبة والمودة، فالاستعارة تصور إلى أي مدى كان القروي رقيقًا مع عدوه وأنه كان يحافظ على شعوره إلى درجة كبيرة، في حين أن عدوه لم يقدِّر ذلك منه، ويؤكد هذا المعنى قوله "فاني جئتُ بالروحِ اللطيفِ"؛ إذ عبر الثاعر إنى

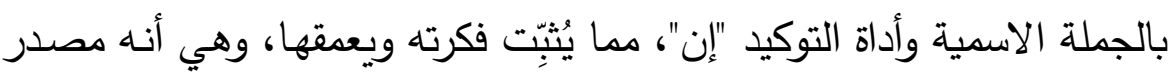
خير وسعادة لعدوه، وعدوُه لم يقدِّر ذلك.

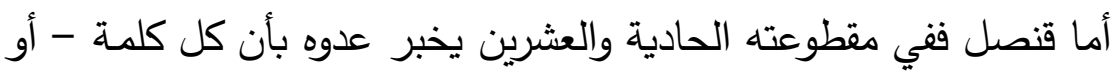
سطر - كتبها في هذه القصيدة تحمل له كل معاني الخير له، يقول قنصل:

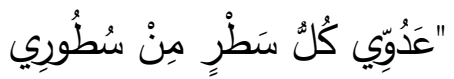

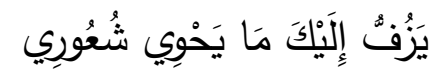

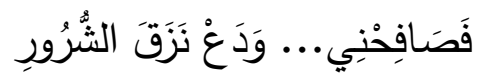

وَنَمْ - إِنْ شِنْتَتَ - مرْْنَاحَ الضَّمِيرِ

قَرِيرَ الْعَيْنِ لَيْنَ يَخَافُ صَرْفَاِ 
أثر التصوير البياني والتحسين البديعي فِ أداء معنى الصفح هٍُ الشعر المهجري: القروي

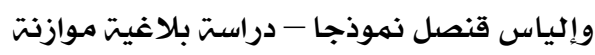

حوليت كليت اللغت العربيت بإيتاى البارود (العدد الثالث والثلاثون)

ويوظف قنصسل في مقطوعته هذه فن الاستعارة، ليخرج مـا بداخله مـن

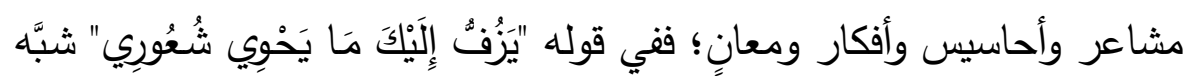

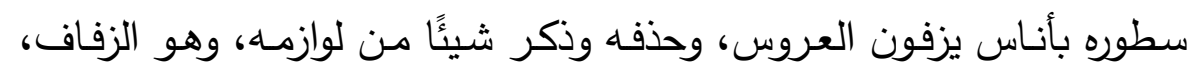

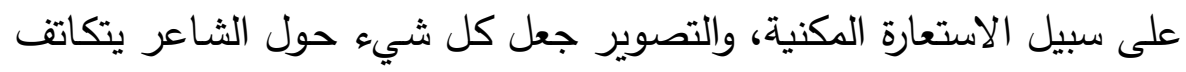
معـه ويعاونـه على إصـلاح عدوه وجذبـه إليه، حتى حروفهـ وكلماتـه وسطوره المكتوبة كانت تيؤزره في هذا الأمر .

وفي المقطوعة الثانية والعشرين يدعو كل شاعر منهما عدوَّه إلى المحبة

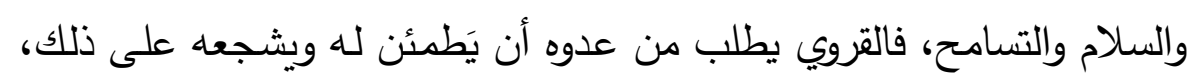

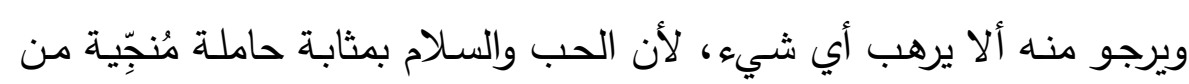

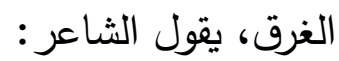

"عدوّي بحرُ حبيَ قد ترامى فخُضْ أَو غُصْ ولا تخش ارتطاما

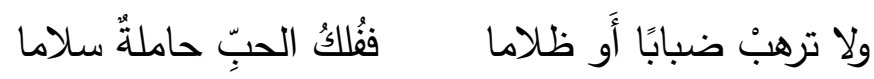
تحفتُ بها جواري الأمنِ حفّا" وقد اعتمد القروي في مقطوعته هذه على فني التشبيه والاستعارة في التصوير، فالتشبيه البليخ كما في قوله "عدوّي بحرُ حبيَ قد ترامى"؛ إذ شبه هدهيه

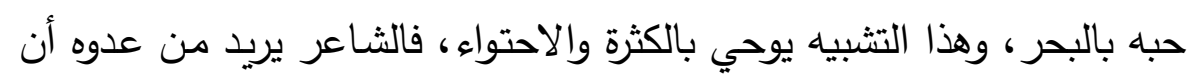

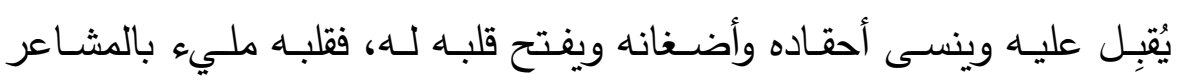
الطيبة، وأقوى هذه المشاعر الحب. ولئ. ثم شبه الحب كذلك بالفلك تشبيهًا بليغًا في قولـه: "فُفلكُ الحبٍّ حاملـة

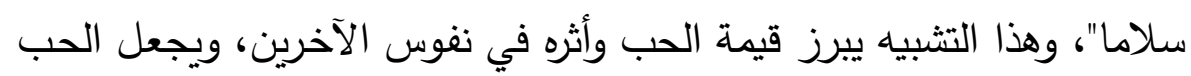
مَعبرًا ونجاة من مهالك الفكر وأحقاد القلوب. وهاب. ويترك القروي فن التثبيه ليتعمق في الخيال فيذهب إلى الاستعارة في قوله "تحفُّ بها جواري الأمنِ حفّا"؛ إذ شبه الأمن بالبحر ، ثم حذف المشبه به وذكر

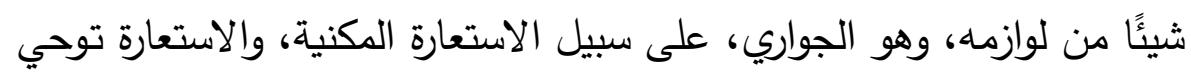


أثر التصوير البياني والتحسين البديعي فِ أداء معنى الصفح هٍُ الشعر المهجري: القروي

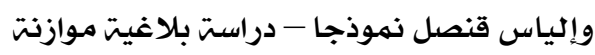

\section{حوليت كليت اللغت العربيت بإيتاى البارود (العدد الثالث والثلاثون)}

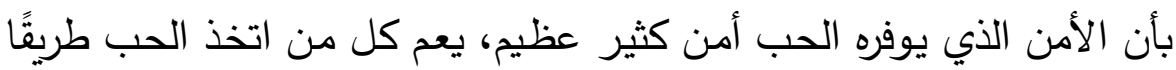
لله ومنهجًا لحياته، وأنه منجاة من كل مهلكة.

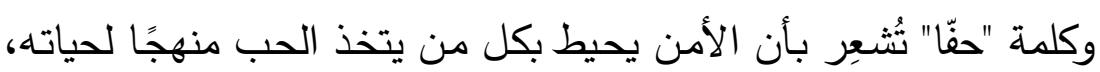

ويلفه من كل جانب؛ مما يوحي بأن الحب يقي من كل الثرور والمخاطر . وقنصل في مقطوعته الثانية والعشرين يحث عدوه على الاطمئنان لله وعدم الخوف منه، لأنه لا يحمل في قلبه له أي شيء يدعو للتجافي والضـينهيه وليقول قنصل:

"عَدُوِي لَ لَخَفْ مِنِّي... فَمَا فِي

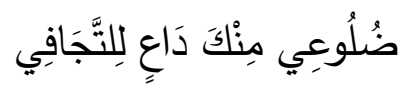

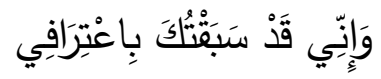

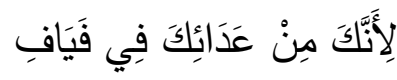

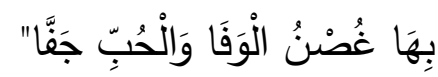

ويتتوع تصوير قنصل في مقطوعته هذه بين المجاز المرسل والاستعارة

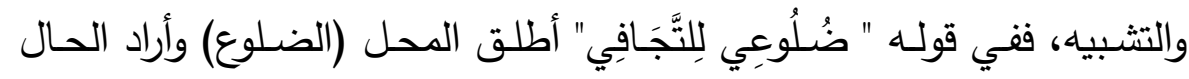
(القلب)، على سبيل المجاز المرسل لعلاقـة المحليـة، وهذا المجـاز يوضـح العلاقـة بين الضـلوع والقلب، فهي علاقـة قويـة جدَّا، بحيث يمكن أن يحل

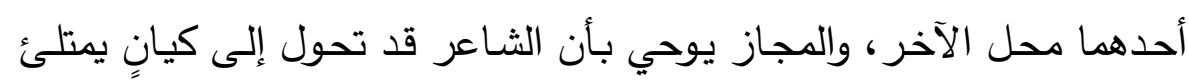
إحساسًا بالود والقرب وعدم التجافي لعدوه.

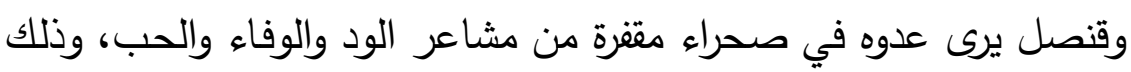

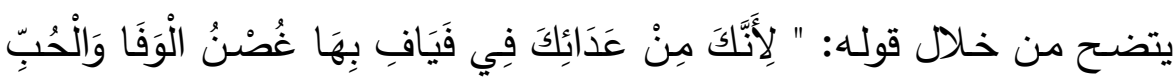
جَفَّا"؛؛ فقد شبه حال عدوه وهو يعيش حالة من الحقد والغل، والكراهية والغدر

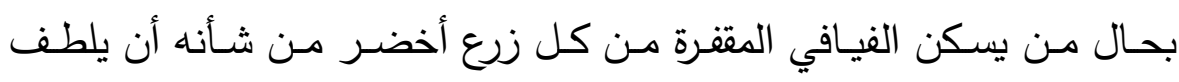
الأجواء وينقي الهواء على سبيل الاستعارة التمثيلية، والتصوير يوضـح إلى أي 
أثر التصوير البياني والتحسين البديعي هِّ أداء معنى الصفح هٍِ الشعر المهجري: القروي

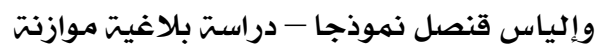

حوليت كليت اللغت العربيت بإيتاى البارود (العدد الثالث والثلاثون)

مدى قد خلا قلب عدوه من كل المشاعر الطيبة وحل محلها المشاعر الخبيثة التي تضر باه قبل عدوه.

وتتعانق الاستعارة مع التصوير في قوله " غُصْنُ الْوَفَا وَالْحُبِّ "، إذ يشبه الثاعر الوفاء والحب بشجرة لها أغصان وحذفها وذكر شيءً من لوازمها على

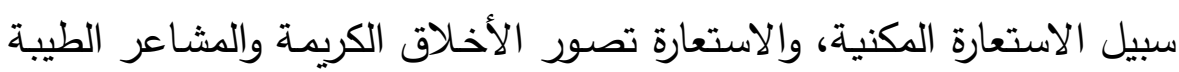
بشجرة وارفة، وأن كلَّا من الوفاء والحب غصنان من أغصانها، وهما يبدآن صغيرين ثم ينموان حتى يصيرا خُلقين يستظل بهما صاحبهما من شقاء الحياة وان ونئ

ومتاعبها.

وفي المقطوعة الثالثة والعشرين يكمل الثاعران كلامهما مع عدوِهما، لكن

كلٌ على طريقته، فالقروي يقرر لعدوه حقيقة مهمة، ألا وهي الموت المحتوم على كل المخلوقات، ويحث عدوه بالأخذ بنصائحه قبل فوات الأوان ودفنه في

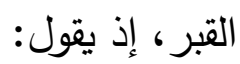

"عدوي سوف تطحنُنا القبورُ وتتخلُنا وتجبلُنا الدهورُ

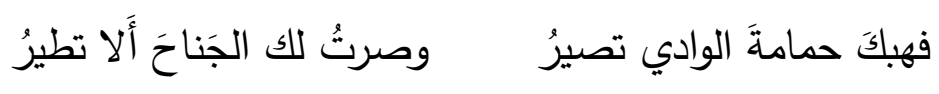
أَو العُش الطريّ ألست تدفا؟!"

وتتــآزر العناصـر التصــويريـة فـي مقطوعـة القـروي هـذهـ بـين الكنايــة

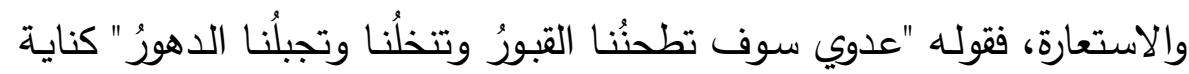
عن الهلاك والفناء، بل التلاشي، وهذه الكناية تصور مصير الإنسان ونهايته

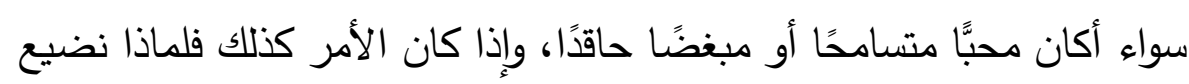

$$
\text { العمر في الحقد والحسد والكراهية؟ مناء }
$$

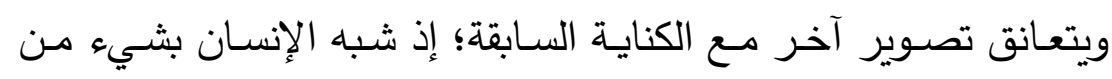

شأنه أن يطحن وينخل، ثم حذف المشبه بـه وذكر شيَيَّن من لوازمـه، وهما

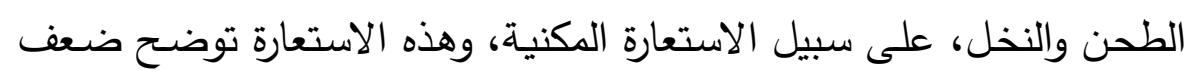

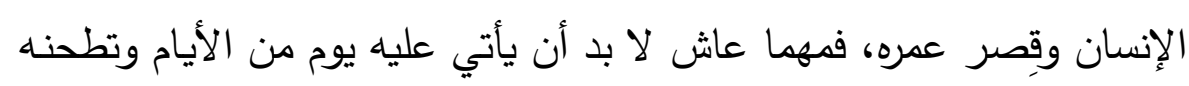


أثر التصوير البياني والتحسين البديعي فِ أداء معنى الصفح هٍُ الشعر المهجري: القروي

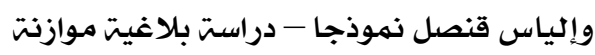

حوليت كليت اللغت العربيت بإيتاى البارود (العدد الثالث والثلاثون)

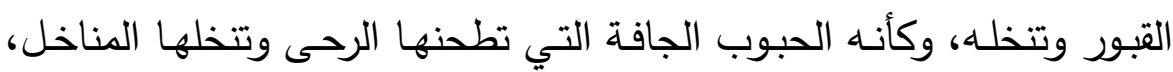
كما تشعر بأن الإنسان سينتهي ويتلاشى ولم تبقَ منه إلا سيرته وأعماله.

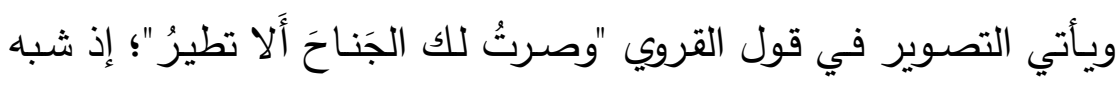
عدوه بطائر ثم حذفه وذكر شيئًا من لوازمها، وهو الجناح والطيران على سبيل الاستعارة المكنيـة، والتصـوير يوحي برغبـة الثـاعر القويـة في أن ترقى روح عدوه وتُشفى من الأمراض النفسية، كالحقد والحسد وسوه الظن، بحيث يمكنه برونه التحليق في عالم الصفاء والنقاء. أما قنصل ففي مقطوعته الثالثة والعشرين قد تطرَّق في خطاب عدوه إلى في

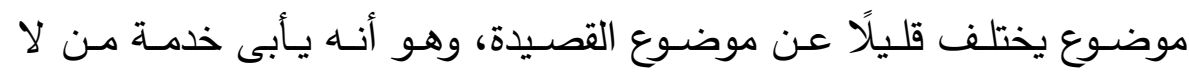

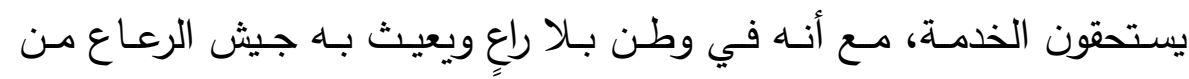

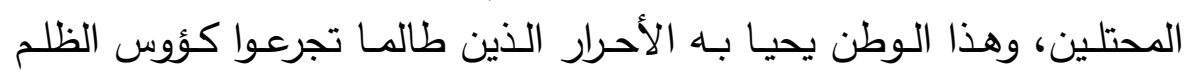
والعسف والقهر ، يقول قنصل:

"عَدُوِي لَسْتُ أَخْدِمُ فِي يَرَاعِي

سِوَى وَطَنْ غَدَا مِنْ دُونِ رَاعِ

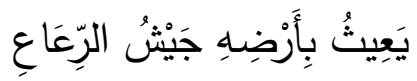

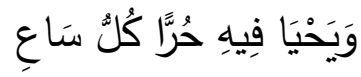

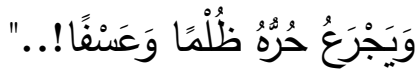

وقد آثر قنصل في مقطوعته هذه التعبير بالفن الكنائي؛ إذ كنَّى بقولهـ

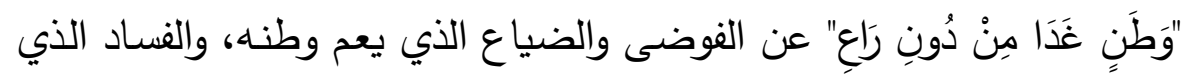
يملأه في تلك الفترة، وهذه الكناية تصور الثعور بالأسسى والمرار الذي يملأ كيان قنصل من الفوضى التي تعم وطنه والفساد الذي يملأه.

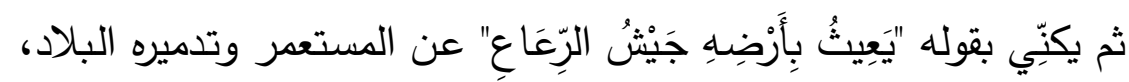

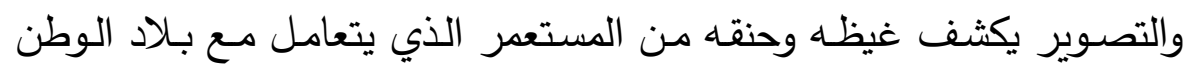
باستهتار ولا مبالاة، كما أنه يتصرف فيها وحرية، وكأنها بلاده. 
أثر التصوير البياني والتحسين البديعي هِّ أداء معنى الصفح هٍِ الشعر المهجري: القروي

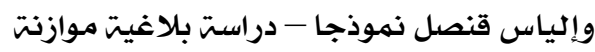

حوليت كليت اللغت العربيت بإيتاى البارود (العدد الثالث والثلاثون)

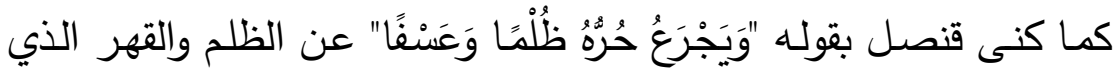
يثعر بـ الأحرار في وطنه، والكناية توضـح إلى أي مدى كان يعاني أحرار - الوطن من الظلم والقهر

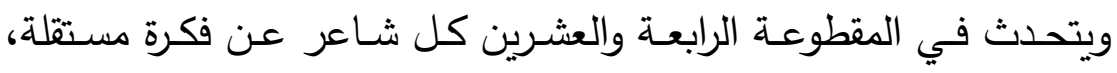

فالقروي يلفت في مقطوعته نظرَ عدوه إلى حقيقة، ربما لم يكن يلتقت إليها، وهي أن الأشياء القاسية القوية لا تستمر على قسوتها أو قوتها، فقد تكون في وقت آخر رقيقـة ضـعيفة كالسـيل والـريح؛ فالسـيل أحيانَا يجترف الصـخور وأحيانًا أخرى ينقلب خريرًا، والريح أحيانًا تقتلع الجذور وأحيانًا تكون هادئة

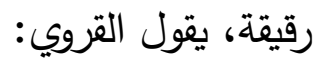

"وهَبك السيلَ يجترفُ الصخورا وهبك الريخح تقتلعُ الجذورا أَلَست تراهما انقلبا خريرا وهينمةً يهزَّان الزهورا

وسالا في الرياض ندى ولطفا؟"

وقد وجد القروي في مقطوعته هذه بغيته في الأسلوب الكنائي؛ إذ كنَّى بقوله "وهَبك السيلَ يجترفُ الصخورا وهبك الريحَ تقتلعُ الجذورا" عن قوة السيل والريح، والكناية تصور السيول والصخور وهما في قمة الثدة والعنف والقسوة.

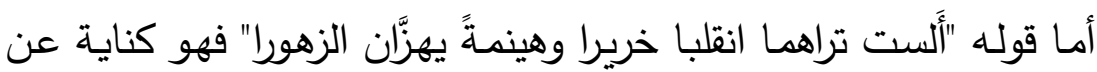
الرقة والعذوبة، وهذه الكناية تصور السيل والريح وهما في قمة الرقة والنعومة والهدوء، ويؤكد هذا المعنى قوله "خرير"، فصوت الخرير مـا هو إلا مداعبـة الرياح للماء المعبَّر عنه بالسيل.

أما قنصل فقد اهتم في مقطوعته الرابعة والعشرين بتذكير عدوه بنصحه باحه الكثير له، ويرجو منه أن يأخذ بهاه ويبادر إلى صُلْحِه، يقول قنصل:

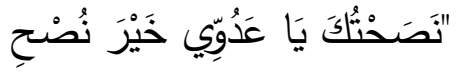

$$
\begin{aligned}
& \text { هَلُمَّ إِذًا ... وَهَاتِ شُرُوطَ صُلْحِي } \\
& \text { وَلَا تَزَهَبْ بُقْرْبِي أَيَّ لَفْحِ }
\end{aligned}
$$


أثر التصوير البياني والتحسين البديعي هِّ أداء معنى الصفح هٍِ الشعر المهجري: القروي

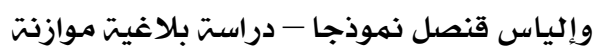

حوليت كليت اللغت العربيت بإيتاى البارود (العدد الثالث والثلاثون)

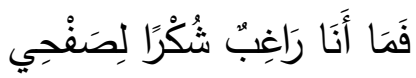

وَلَا أَنَا أَبْتَغِي مَدْحًا وَزْلْفَىَى

ولقد لجأ قنصل في مقطوعته هذه إلى التعبير بالتصوير الاستعاري، ففي

قولهه " لَفْحِ" شباه نقده الـلاذع باللفح، ثم استعار اللفح للنقد الاذع على سبيل الاستعارة التصريحية الأصلية، والاستعارة تصور نقد قنصل الثديد لعدوَه، فقد

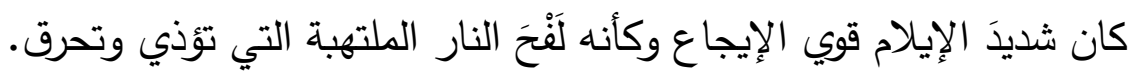

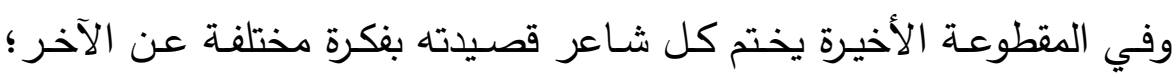
فالقروي يطلب من عدوه أن يقف وقفة تأمل ويطالع آيات السماء من نجوم

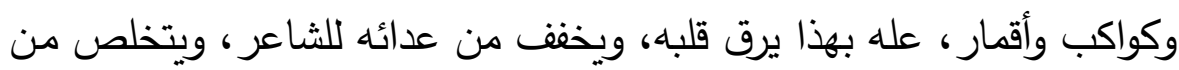
الحقد والغل والحسد، إذ يقول:

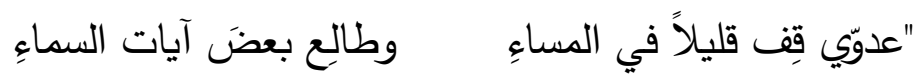

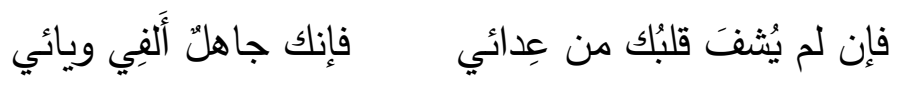

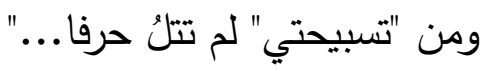

وقد جاءت مقطوعة القروي هذه خالية من كل أشكال التصوير ؛ إذ نجده قد عبر بأسلوب مجرد غير مشفوع بأيَّة صورة فنية، لأن هذه الطريقة الأنسبُ في نظره لأداء المعنى.

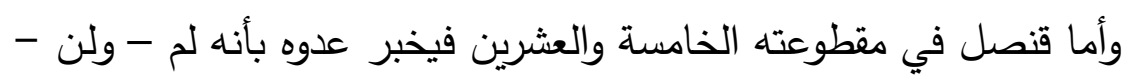
يطلب منه مالًا ولم يرضَ المذلة والسؤال، فهو عفيف النفس قنوع، كما يخبره

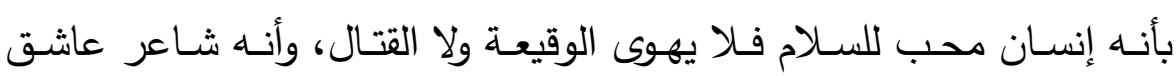

للجمال، ولم يبسط لغير الحب كفه، يقول قنصل:

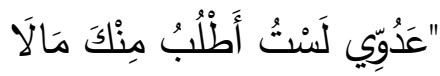

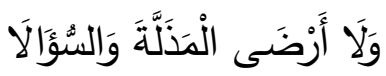

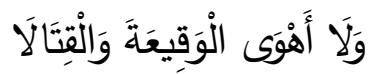

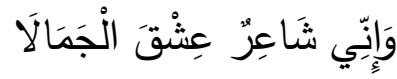


أثر التصوير البياني والتحسين البديعي فِّ أداء معنى الصفح بِّ الشعر المهجري: القروي

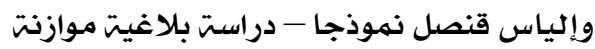

حوليت كليت اللغت العربيت بإيتاى البارود (العدد الثالث والثلاثون)

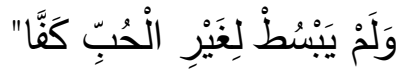

وقد استخدم قنصل في مقطوعته الأخيرة كـلًا من الأسلوب الكنائي والأسلوب

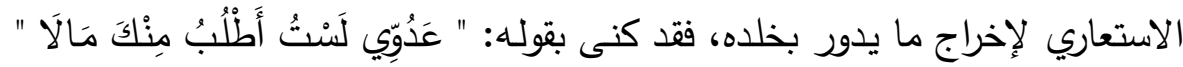

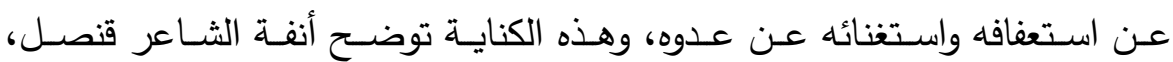
وإحساسه العالي بكرامته.

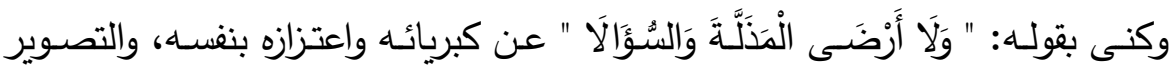
يوحي برفضه الإهانة من أي شخص مهما كان هذا الثخص ولئه ومكانته.

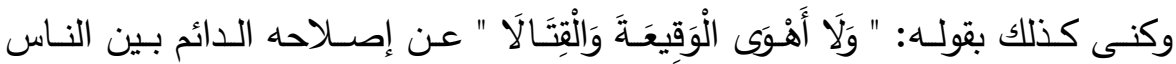
وتجميع شتاتهم، والكناية توحي بحب قنصل الخير للناس حتى ولو كان عدوًا لـه، وتثعر كذلك بسلامته النفسية، وسلمه الدائم مع الناس حتى ولو كان هؤلاء أعداءه.

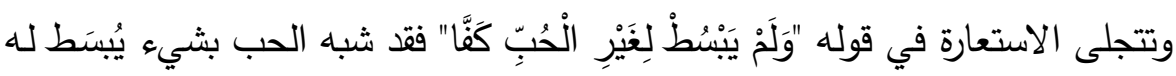

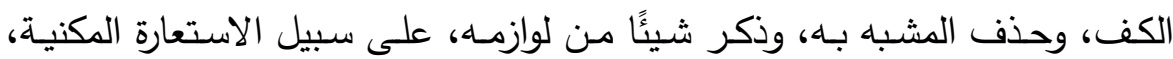

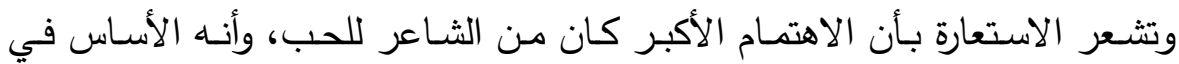

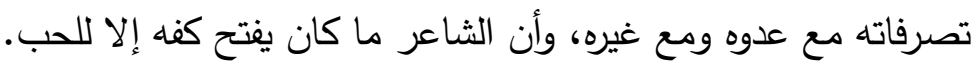

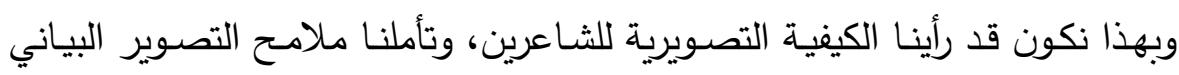

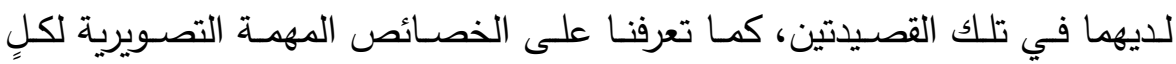
منهما. 
أثر التصوير البياني والتحسين البديعي ِِّْ أداء معنى الصفح ِِّ الشعر المهجري: القروي

وإلياس قنصل نموذجا - دراست بلاغيت موازنت

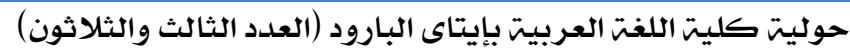

\section{المبمث الثاني}

\section{أثر التصسين البديعي والنغم الموسيقي في أداء همنى الصفح بين}

\section{القروي وإلياس قنصل-دراسة بلاغية هوازنة.}

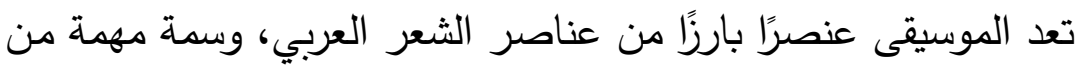

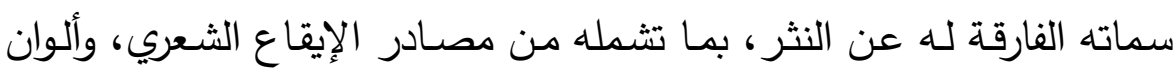
الجرس اللفظي، وطلاوة الترنيمات البديعة. وإذا كان إمتاع المتلقي هدفًا أساسيًّا من أهداف الثـاعر فإن موسيقى أنى الثعر تعاونه على التأثير في وجدان المتلقين، وتحريك مشاعرهم، لأنها "تزيد من انتباهنا، وتضفي على الكلمات حياة فوق حياتها، وتجعلنا نحس بمعانيه

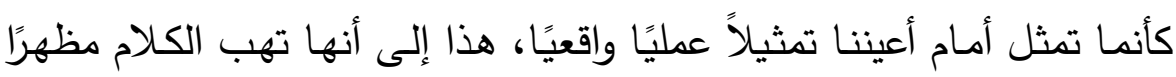

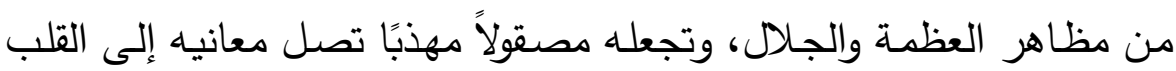
بمجرد سماعد * (1)

إن متأمل قصيدتي القروي وقنصل - وهما شاعران من شعراء المهجر الجنوبي - يجد لديهما عناية شديدة بموسيقى الشعر ، وإدراكًا عظيمًا لأهمية

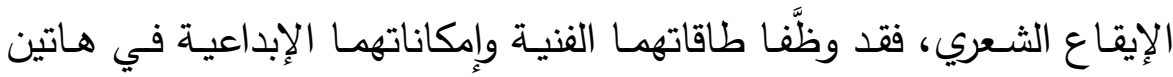
القصـيدتين لتحقيـق المسـتوى اللائقق لموسـيقى شعرهما؛ "فموسـيقى الألفـاظ والأوزان في الثـعر تقابلها موسيقى النغم والألحان في الغنـاء، وبذلك يكون الثعر أوقع أثرًا على النفس من سائر الفنون الأدبية لما فيه من سحر النغم، وسئ

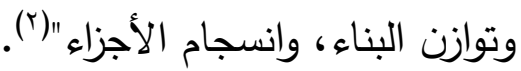

وقـد تتوعـت الظـواهر الموسـيقية في القصـيدتين - محسل الدراسـة وتمثلت في عنصرين رئيسين؛ هما:

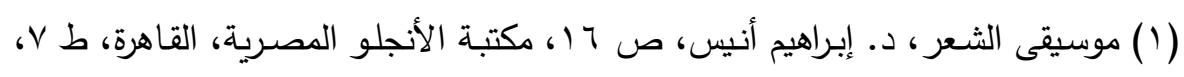
. 997 
أثر التصوير البياني والتحسين البديعي هِّ أداء معنى الصفح هٍِ الشعر المهجري: القروي

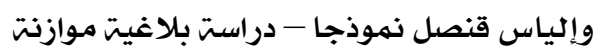

حوليت كليت اللغت العربيت بإيتاى البارود (العدد الثالث والثلاثون)

( ) (الموسيقى الخارجية.

r الموسيقى الداخلية.

أولاً: الموسيقى الخارحية:

تتمثل الموسيقى الخارجيـة في الوزن والقافيـة، وقد رأى النقاد العـرب القدامى في الوزن مكونًا أساسيَّا لا يستقيم الثعر إلا به، ( فالوزن أعظم أركان

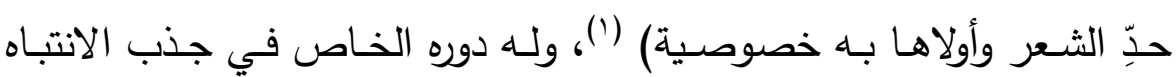
ولفت الأنظار ، مما يساعد على الحفظ، ويبطل سأم التكرار .

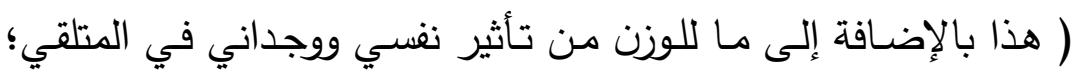

فهو يثبّت القول في الذهن، ويجعله يعلق بالقلب، ويقيده من التشتت) (؟).

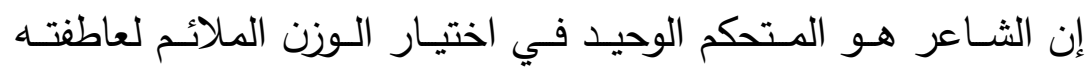
الانفعالية قوة وضعفًا، هدوءً وصخبًا، وهو يستجيب - بوعي أو بدون وعي -

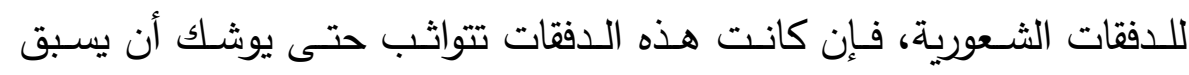

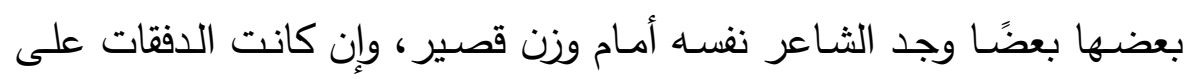
غير ذلك من الوصف بأن كان بعضها يمسك بتلابيب البعض الآخر كانت البحـور الطويلـة ذات التفاعيـل الممتدة، وتسـتوي في ذلـك العاطفـة المشـرقة والعاطفة الغائمة.

وينبغي التتويه إلى أن موقف شعراء المهجر الجنوبي من قضية الأوزان والقوافي - ومنهم القروي وإلياس قنصـل - يعد امتدادًا لموقفهم من قضـية الالتـزام اللغـوي، فقـــ اعتز هـؤلاء الثـعراء بعَروض الخليـل، فسـارت معظم قصائدهم على النهج التقليدي السائد الذي يتخذ قوامًا لـه الشطرين المتكافئين، والقافية الموحدة، وطول النفس، والعناية بالمطلع، محاولين إثبات مقدرتهم على

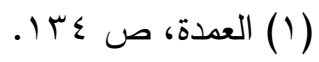

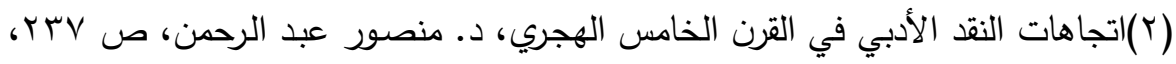

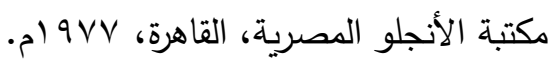


أثر التصوير البياني والتحسين البديعي هِّ أداء معنى الصفح هٍِ الشعر المهجري: القروي

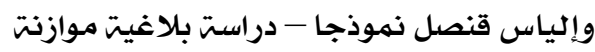

حوليت كليت اللغت العربيت بإيتاى البارود (العدد الثالث والثلاثون)

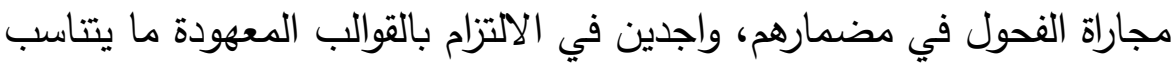
مع ما يعتنقونه من قيم.

لقـــ آثر شـعراء المهجر الجنـوبي الـنظم في البحسور ذات التقعيلات

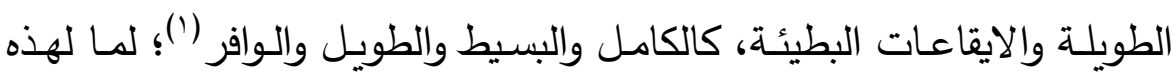
البحور من قدرة على احتواء تجاربهم الثعورية الصادقة، وانفعالاتهم العاطفية المتأججة، فهي تعطي للشـاعر مجالًا رحبًا يسمح لله بإخراج فيض مشـاعره، وإفراغ سيل عواطفه.

وقد آثر القروي بحر الوافر لينسج عليه قصيدته (تسبيحة الحب)، وتبعه في ذلك قنصل بمعارضته تلك القصيدة، إذ نسج قصيدته (ترنيمة الصفح)؛ لما لهذا البحر من رحابة واتساع يسمحان باستيعاب الانفعال المنساب، والثعور

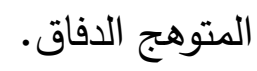

لقد استوعبت تفاعيل بحر الوافر لدى الشاعرَين مشاعر الحب والمودة

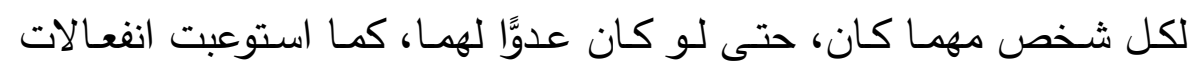
الغضب والحنق تجاه الذين يتخذون من الكراهية والحقد منهجًا لحياتهم، ومن الغل والحسد أسلوبًا لعيشهم.

( فالبحر المستخدم من البحور كثيرة الحركة) (؟)، التي تعطي دائمًا

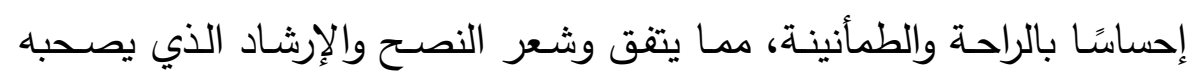

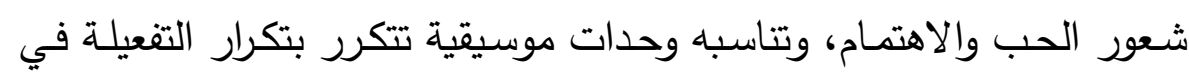
نسق نغمي تألفه الأذن وتطرب له النفس.

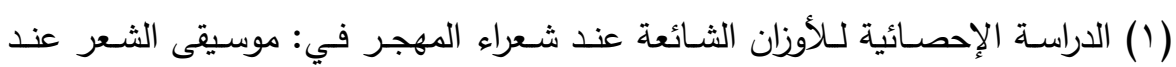

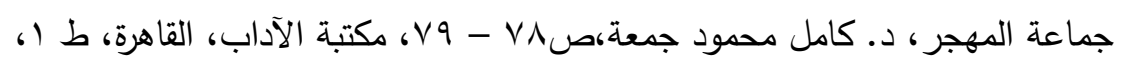
.ه $\leqslant$ 个

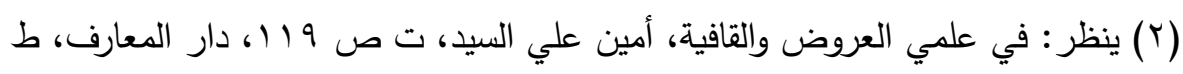

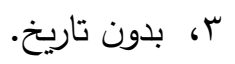


أثر التصوير البياني والتحسين البديعي هِّ أداء معنى الصفح فِ الشعر المهجري: القروي

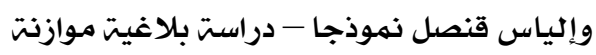

حوليت كليت اللغت العربيت بإيتاى البارود (العدد الثالث والثلاثون)

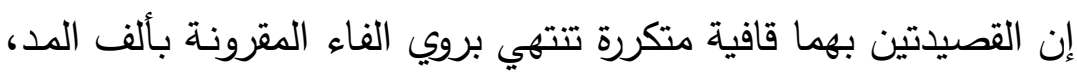
مما يوفر أسباب القوة، ويخرج مع إطلاقها مشاعر الثاعر الصـادقة، وعواطفه بهاء برويه المصبوغة بالمودة والمحبة.

فالثـاعران في هـاتين القصيدتين من أولها إلى آخرها يقدمان النصـح والإرشـاد لعدوِهما ويحثانـه على الصـفح والتسـامح، والمحبـة والتغاضسي، في هي

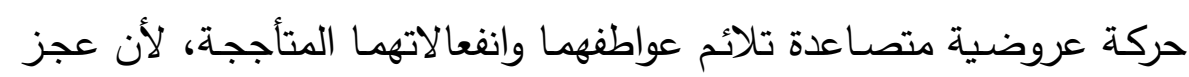
بحر الوافر "سـريع اللحاق بصـدره حتى إن السـامع لا يكـاد يفرغ مـن سماع

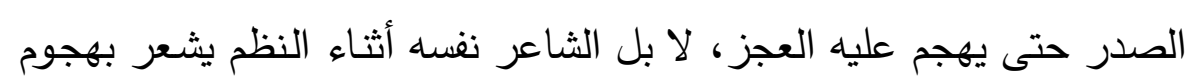
العجز والقافية بمجرد فراغه من الصدر"((').

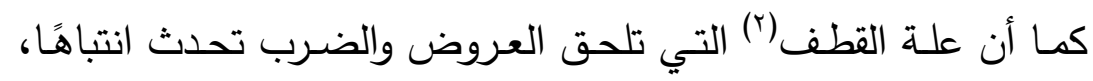
وتعطي بهذا الانتباه مفاجأة، ورنة قوية مناسبة لتوهج العاطفة، وثورة الانفعال.

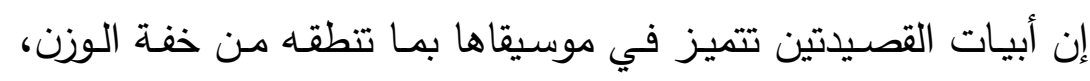
وحلاوة الجرس الموسيقي العذب، فالإيقاعات خفيفة، والنغمات متراقصـة رقيقة تتراءى من خلالها نفسية الثـاعرين المحبة المتسامحة، ومشاعرهما المتسمة بالتواضع والمسالَمَة. والبحر فضـلاً عن أنه يناسب هذه الحالة النفسية التي تقتضـي السرعة

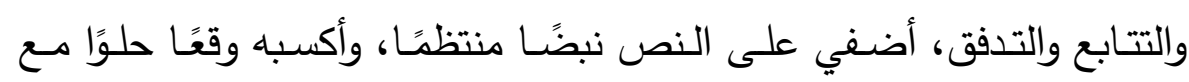
عنصـر ترنمسي ظـاهر، وكلمـات مـوجزة تفي بـالمعنى المراد، وتشـيد بمعـاني التسامح والصفح والمحبة والإخاء.

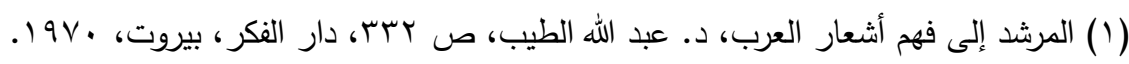

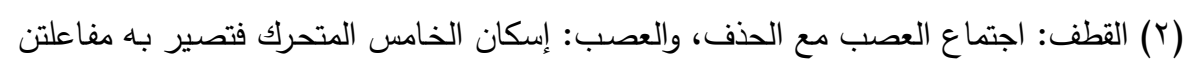

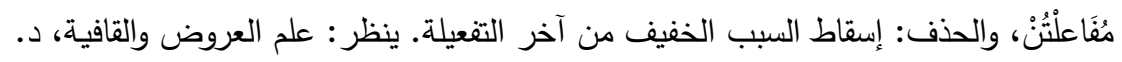

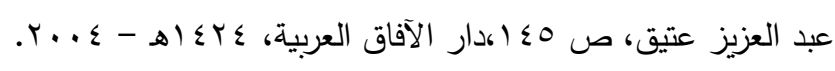


أثر التصوير البياني والتحسين البديعي يِّ أداء معنى الصفح هٍِ الشعر المهجري: القروي

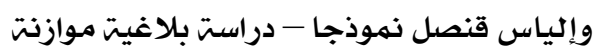

حوليت كليت اللغت العربيت بإيتاى البارود (العدد الثالث والثلاثون)

\section{ثانيًا: الموسيقى الداخلية (المحسّنات البديعية):}

تضـاف إلى كل ما سبق، من موسيقى خارجية، موسيقى داخلية عذبة

منبعثة من قدرة الثاعرين على اختيار المحسِّن البديعي المناسب للمعنى، كما تتضح من خلال إيثار بعض المفردات الهادئة الرقيقة على بعضها، واستخدام التراكيب القوية، والتصرف فيها بذكاء وتطريب.

عرَف الثاعر القروي وكذلك إلياس قنصل لهذه الموسيقى أثرها العظيم في التنغيم والتطريب، ودورها المؤثر في ضبط التساوق النغهي للأبيات حزنًا

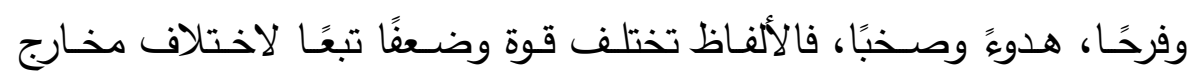
الحروف وصفاتها، فتتتج تبعًا لذلك كلمـات متفاوتـة ( في رنينها، ونغماتها

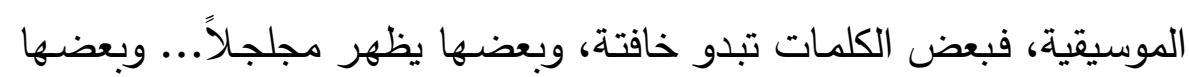
تحس فيه طلاوة، وبعضها تلمح فيه الرخاوة) (')

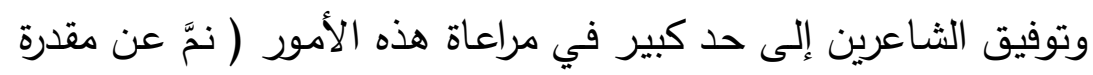

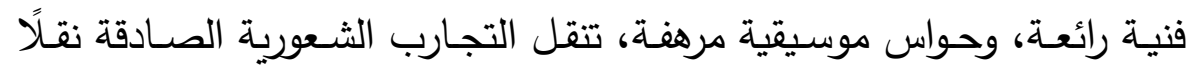

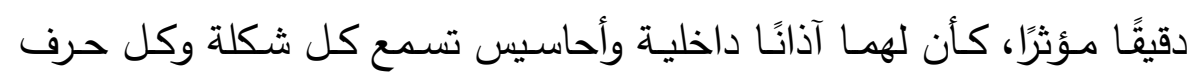

وحركة بوضوح تام) (ץ)

إن الموسـيقى الداخليـة التـي يستشـعرها القـارئ، داخـل نسـيج أبيـات القصيدتين، ( كانت موجهة لخدمة التجربـة الثعرية، وإثراء المعنى وتأصيله في النفوس، بحيث يتجاوب هذا النغم مع حركة النفس في انفعالها الجياش، وإلا تحولت الإيقاعات الداخلية إلى نوع من الجلبة الصوتية سرعان ما ينطفئ هـئ

بريقها ويجمد صداها) (r) - (r)

(1) الأصول الفنية للأدب، د. عبد الحميد حسن، ص Vr، مكتبة الأنجلو المصرية، القاهرة، ط ك، $.197 \varepsilon$

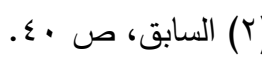
(r) التجديد الموسيقي في الثعر العربي، د. رجاء عيد صع ال، منشأة المعارف، الإسكندرية، 
أثر التصوير البياني والتحسين البديعي هِّ أداء معنى الصفح هٍِ الشعر المهجري: القروي

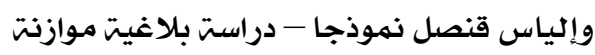

حوليت كليت اللغت العربيت بإيتاى البارود (العدد الثالث والثلاثون)

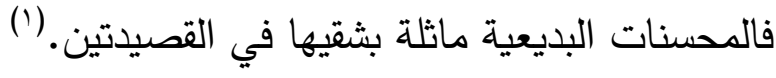
يقول القروي في المقطوعة الأولى:

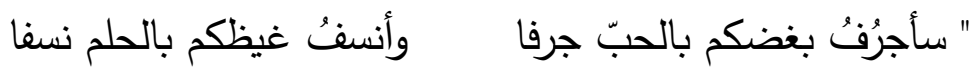

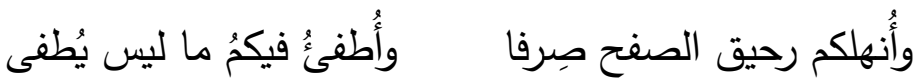
وأشفي منكٌُ ما ليس يُشفي

وقد استعان القروي في المقطوعة هذه بعدد من المحسنات البديعية.

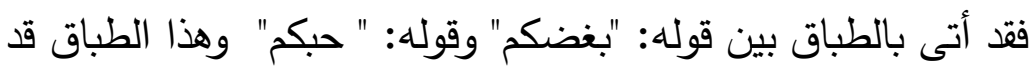

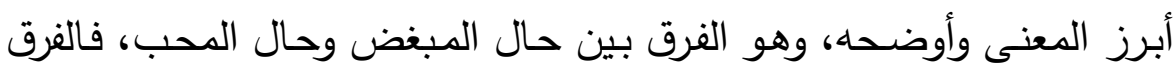
بينهمـا شديد، والهوة بينهما بعيدة، فالأول قلبه مليء بالكراهيـة والغل دائمًا،

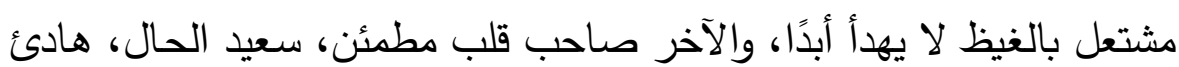
البال، مقبل على الحياة والدنيا. وكذلك الطباق بين قوله: " غيظكم " وبين قوله: " الحلم "، وقد نقل

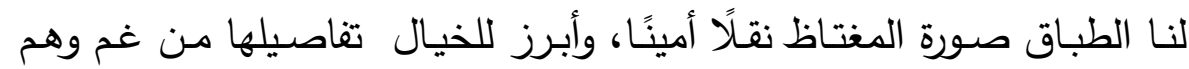
وسراع نفسي يعيشه المتصف بهذه الصفة، وألقى الضوء على صورة الحلم، وأبرز خطوطها وتقاسيمها المهمـة مـن هدوء وسـلام نفسي وطمأنينـة غـامرة

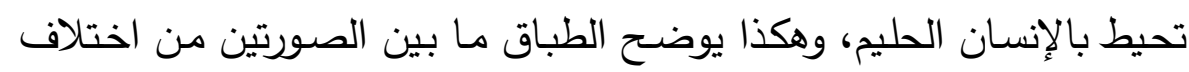

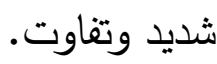

(1) القصيدة الأولى للقروي، وتسمى القصيدة بتسبيحة الحب وعدد مقطوعاتها: خمس

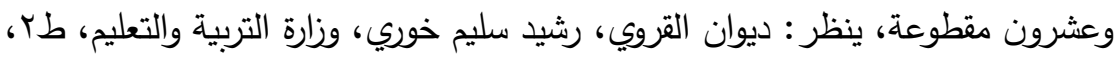
.1971

والقصيدة الثانية لقنصل، وتسمى بترنيمـة الصفح، وعدد مقطوعاتها:خمس وعشرون

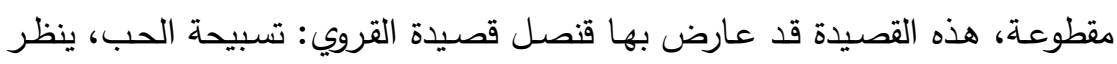
ديوان إلياس قنصل: الأسلاك الثائكة.

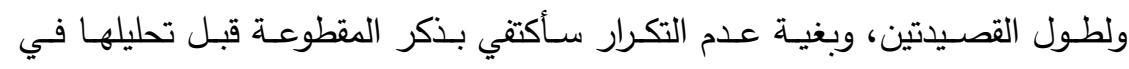
موضعها ولم أذكر نص القصيدتين بثكل كامل مستقل عن التحليل. 
أثر التصوير البياني والتحسين البديعي هِّ أداء معنى الصفح مِّ الشعر المهجري: القروي

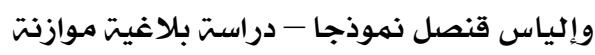

حوليت كليت اللغت العربيت بإيتاى البارود (العدد الثالث والثلاثون)

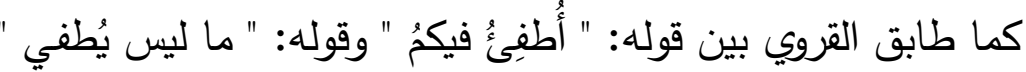

طباقًا سالبًا، وقد أوضح الطباق قدرة القروي على الإتيان بما هو مستحيل في في في نظر الكثيرين، وهو إطفاء نار الحقد والحسد ولهيب الغل والغيظ في قلوب الأعداء وهذا ليس يسيرًا، كمـا يبرز الطباق إمكاناته الخاصـة في أن يـأتي بالثيء وضده، فهو يستطيع أن يدرم النار في قلوب الأعداء بجعلهم يغيرون

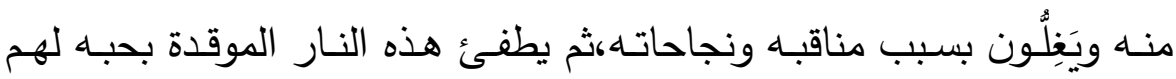

وحلمه عليهم.

ولم يكن الطباق في هذه المقطوعة مجرد محسن بديعي فحسب؛ بل إنه

قد منح المعنى الذي أراده القروي سعة وإحاطة وشمولية.

فالطباق مع تجميله اللفظ ( فإنه يؤدى غرضا معنويا حيث يستوعب لهب

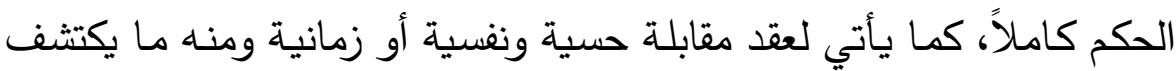

أجزاء القضية ويبرز أطرافها، مما يؤكد أن الطباق من الأمور الفطرية المذكورة

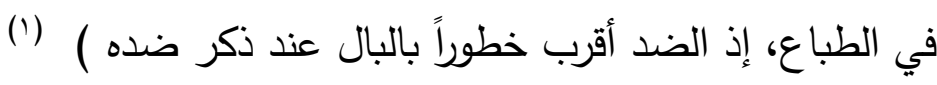

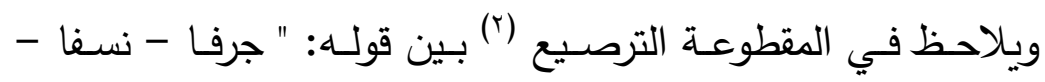

صِرفا "؛ إذ اتفقت الكلمات الثلاث وزنًا وتقفيةً، فللترصيع دور لا يقل أهمية لهية عن التصريع بما يضفيه على مقاطع المقطوعة الداخلية من موسيقى عذبة تتعاون مـع موسيقى الوزن والقافية في إحكام القالب النغمي لكل مقطوعات القصيدة.

وكذا السجع (ז) المطرف بين قوله: " صِرفا " وقوله: " يُطفي "، فقد اتقق

(1) البديع رؤية جديدة د / عبد الله دراز ص ع ا بدون تاريخ.

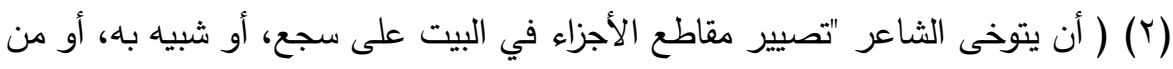

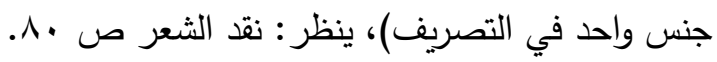

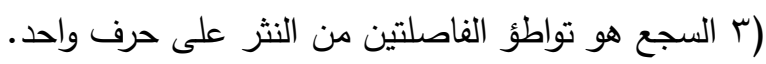

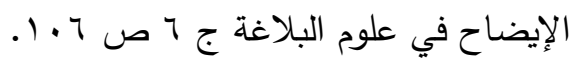


أثر التصوير البياني والتحسين البديعي فِ أداء معنى الصفح هٍُ الشعر المهجري: القروي

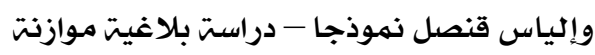

حوليت كليت اللغت العربيت بإيتاى البارود (العدد الثالث والثلاثون)

اللفظان في القافية واختلفا وزنا.

ويتضح الجناس اللاحق 'بين الكلمتين: " يُطفى - يُشفي "، وقد أضفي

كلٌّ من السجع والجناس على المقطوعة موسيقى عذبة تتناسب وشعور التحدي

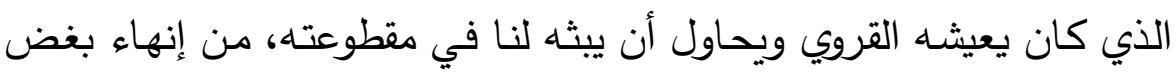
أعدائهـ والقضـاء على غيظهم بحبه وحلمـه، فموسيقى المقطوعـة عاليـة جلبة أطربت الأذن وهزت الوجدان، وقد نبعت هذه الموسيقى من الإيقاع المتكرر

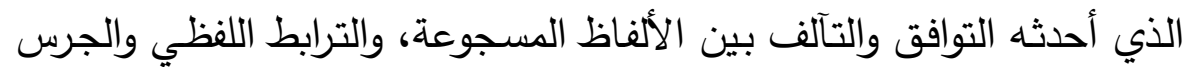
الصوتي وهذا ما صرح به الثيخ عبد القاهر في قوله: ( وعلى الجملة فإنك لا تجد تجنيساً مقبولاً ولا سجعاً حسناً حتى يكون المعنى هو الذي طلبه واستدعاه

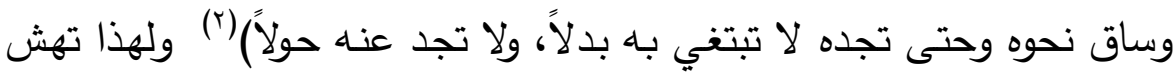
الآذان لمثل هذا النوع من السجع وتلذ له الأسماع وتصني لـه القلوب؛ لحسن لهن لفظه وحلاوة جرسه وجميل إيقاعه. وأروع ما أتى به القروي في مقطوعته صحة الأقسام، فقد قسم تحديه لنفسه ولأعدائه وحاله معهم إلى: جرف بغضهم بحبه، ونسف غيظهم بحلمه، وإنهالهم رحيق الصفح صِرفا، وإطفاء نار ما يصعب إطفاؤه مما يحملون من غل وحقد وكراهيـة وحسـد، وشـفاؤهم مـن مـا لا يرجى شفاؤه مـن المشـاعر

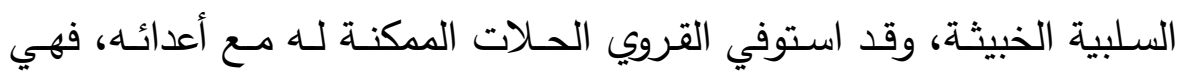
خمس لا سادس لها، واستيفاء الأقسام هذا قد أشعر بأن القروي مُصِر على نجات قومـه مما هم غارقون فيه وسيتحدى كل شيء حتى يصل إلى هدفه

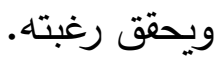

(1) الجناس اللاحق: هو مـا اختلفت فيه الكلمتان في نوع الأحرف والحرفان المختلفان

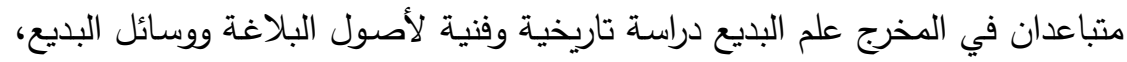

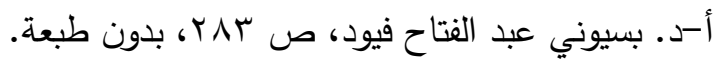

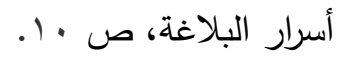


أثر التصوير البياني والتحسين البديعي فِ أداء معنى الصفح فِّ الشعر المهجري: القروي

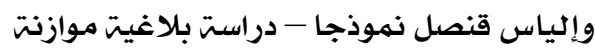

حوليت كليت اللغت العربيت بإيتاى البارود (العدد الثالث والثلاثون) موانة

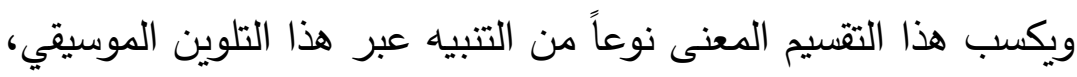

وذلك نابع من تقسيم المقطوعة (إلى مقاطع متتالية متناسقة هي أشبه بالغناء

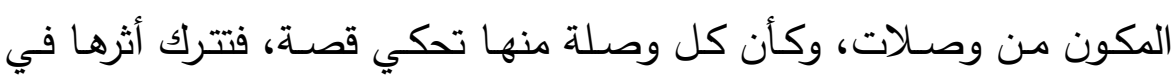

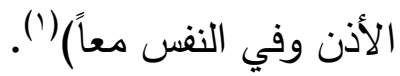

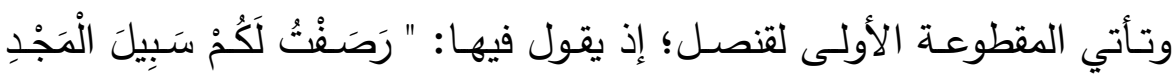
رَصْفَا

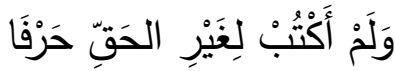

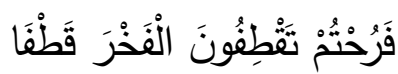

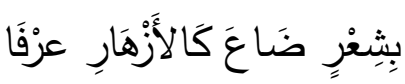

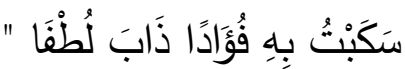

ففي المقطوعـة هـذه يسـعمل قنصـل بعض المحسـنات البديعيـة التي اسـتخدها القـروي كالجنـاس والسـجع، وقـد زاد باسـتخدام فـن مراعـاة النظيـر

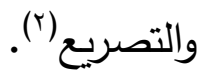
فقد جانس بين قولـه "حَرْفَا" وقولـه "عرْفَا"، جناسًا لاحقًا وهذا الجناس قد أضفي على المقطوعة جرسا موسيقيًا عذبا رقيقا يساعد في تصوير اعتزاز

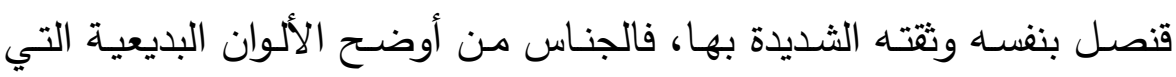

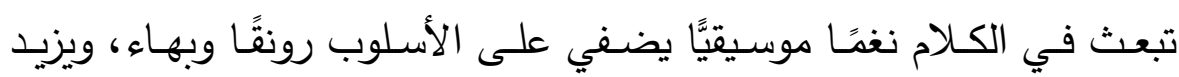

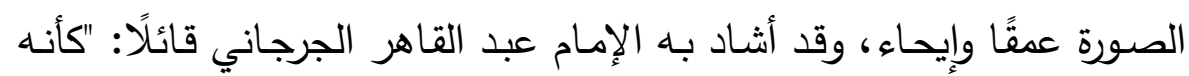

(1) شعر بني أمية في الأندلس حتى نهاية القرن الخامس الهجري د/ السيد أحمد عمارة

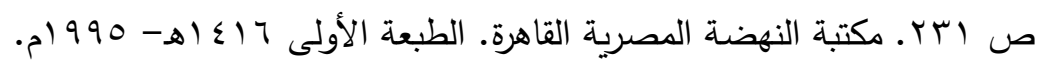
(Y) التصريع: هو جعل العروض مقفاة تفقية الضرب.

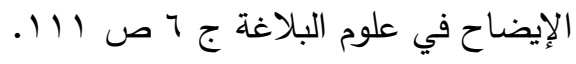


أثر التصوير البياني والتحسين البديعي فِّ أداء معنى الصفح بِّ الشعر المهجري: القروي

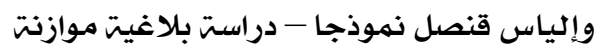

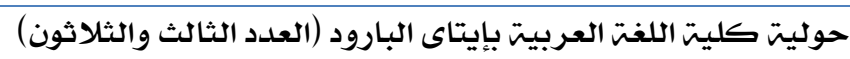

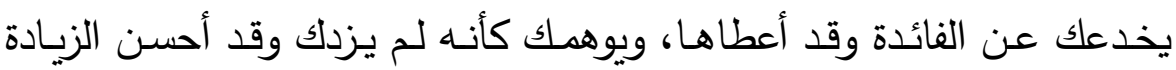

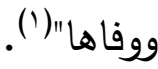

وهذا يعني أن الوظيفة الموسيقية التي يؤديها الجناس تحمل في طياتها بعدًا دلاليَّا من قيمتها الفنية، هذه القيمة قد أدركتها وأشادت بها الدراسة النقدية الحنديثة، فالدكتور علي عباس علوان لا يعد الجناس حلية وزخرفًا، بل يعده مركزًا موسيقيًّا يقابله في البيت مركز موسيقي آخر، إذ يضيفان عليه تنغيمًا

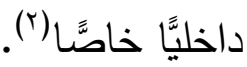

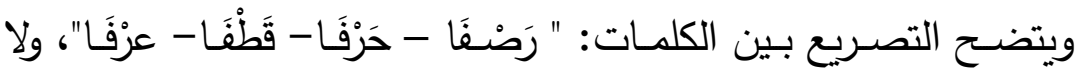

يخفي مـا للتصريع من قدرة على جذب الانتباه وطرب النفس(لاستـ لالها بـ على قافيـة القصيدة قبل الانتهاء إليها، ولمناسبة تحصـل بـازدواج صـيغتي

العروض والضرب، وتماثل مقطعها لا تحصل لها دون ذلك) (־). وقد لاحظ قدامـة بـن جعفر هذه القيمـة الفنيـة للتصـريع فعلل إكثار

الشعراء منه قائلاً:

"وإنما يذهب الثعراء المطبعون المجيدون إلى ذلك لأن بنية الشعر إنما

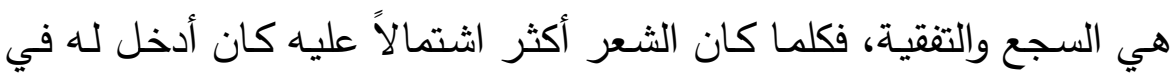
باب الثعر وأخرج لله عن مذهب النثر "(£).

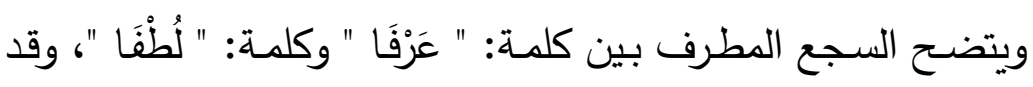
أعطى السجع نغمة موسيقية جميلة ترتاح لها الأذن، وتطرب لها النفس، فهو

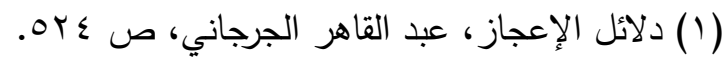

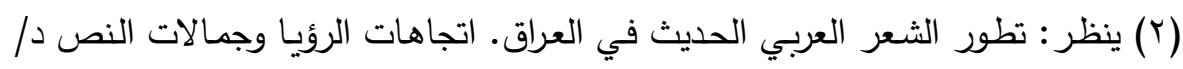

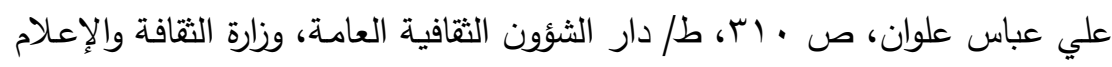
ببغداد. بدون تاريخ.

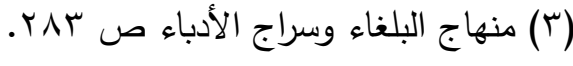

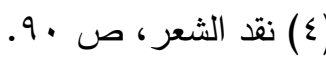


أثر التصوير البياني والتحسين البديعي فِ أداء معنى الصفح هٍُ الشعر المهجري: القروي

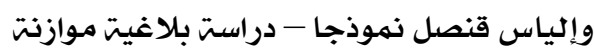

حوليت كليت اللغت العربيت بإيتاى البارود (العدد الثالث والثلاثون)

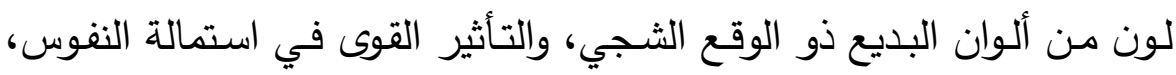
وتنشيط الأذهان، وإنصات الآذان وبخاصة إذا جاء عفوا دون قصد، وله كبير

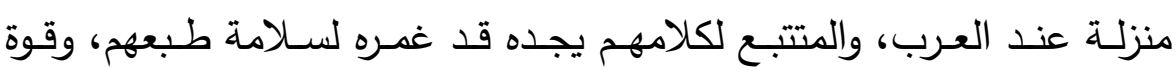
سليقتهم، ووضوح فكرتهم.

ويلاحظ مراعاة النظير بين الكلمتين: " المجد - الفخر "، فكل منهما شعور يجعل صـاحبه سعيد القلب معتزًا بنفسه مزهوًا بحاله، وبلاغة مراعاة النظير تتمثل في تحقيق الإيجاز والاختصـار إذ بوجوده يصبح المعنى أكثر تركيزًا،

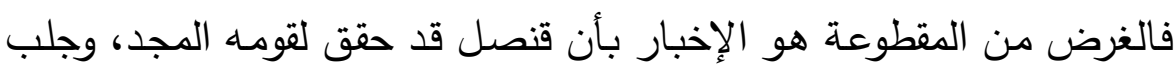
لهم أسباب الفخر والعزة، وليس هذا فحسب، بل أنسه جعل لهم الفخر كزهرة يقطفونها بكل يسر وسـولة، فكان مراعاة النظير أقصر الطرق في أداء هذا الغرض وإدخاله إلى النفوس وتثبيته في الأذهان.

(وهذا الفن البديعي قائم على المصاحبة المعجمية التي تسهم في تحقيق

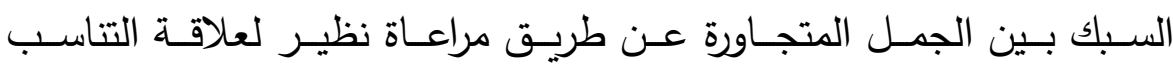
والائتلاف) (')

وتأتي المقطوعة الثانية للقروي:إذ يقول فيها:

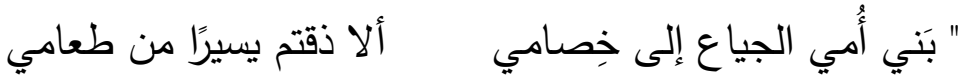
أضرَّ بكم لهيبُ الانتقامٍ فهاكم من يدي كاسَ السلامِ

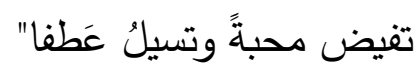

وفي المقطوعة هذه يتنوع استعمال القروي للمحسنات البديعية بين الطباق والسجع والتتاسب والتقسيم

فيتضح الطباق بين قوله "الجياع" وقوله "طعامي"؛ والطباق يبرز الفرق بين

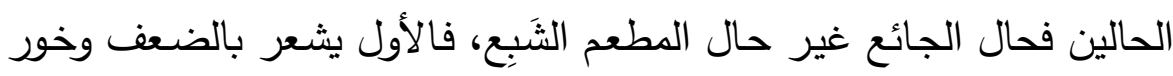

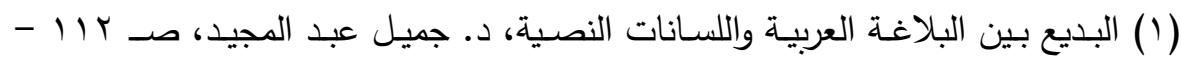

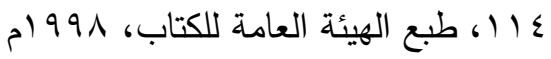


أثر التصوير البياني والتحسين البديعي فِ أداء معنى الصفح هٍُ الشعر المهجري: القروي

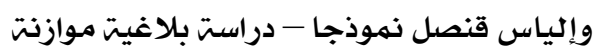

حوليت كليت اللغت العربيت بإيتاى البارود (العدد الثالث والثلاثون)

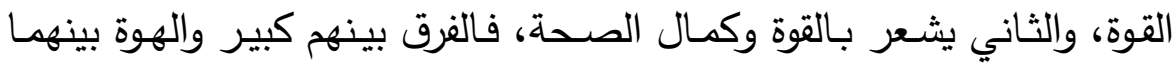
بعيدة، ويشعر الطباق بفضـل القروي على قومـهـ الذين يعادونـه، ويتحَزَّبـون

ضده.

وقد طابق القروي كذلك بين قولهـ: "الانتقامِ" وقولهـ: "السـلامِ"، والطباق قد أبرز المشاعر الحقيقية لكلٍ من المنتقم، والمسالم، فالأول يحمل كل مشاعر لهري الغيظ والحقد والغل، والثاني يحمل مشاعر المحبة والتسامح والمودة، ولا شك أن المفارقة بينهما بعيدة، فنفس المنتقم متوترة دائمة قلقة غير هادئة، والمسالم نفسه مطمئنة هادئة.

وبـين قولـه: " طعــام " وقولـه: "ســام " سـجع متوازي، كمـا يوجد بـين قولـه: "الانتقام" وبين قوله: "السـلام" سجع مطرف، وقد أحدث هذا السجع موسيقى ئى

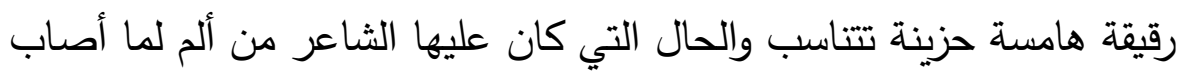
قومه من ضرر بسبب ما يحملونه من لهيب الانتقام. وقد قسم القروي تأثير كأس السلام إلى حالين: الحالة الأولى هي انتشار المحبة، والحالة الثانية سواد العطف والتعاطف بين البشر في قوله: " كاسَ

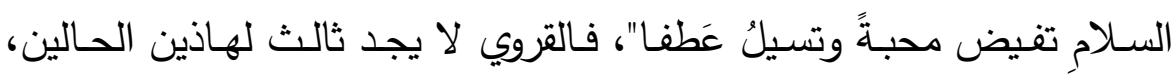
وبالفعل لا ينتُج عن السـلام إلا المحبـة والعطف، ممـا يشـعر برغبـة القروي الملحة في تحقيق السلام والوئام للبشر •

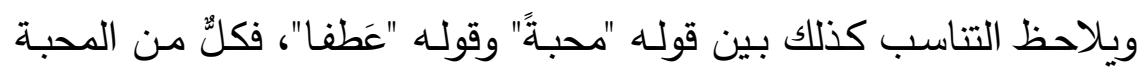
والعطف شعور يجعل صاحبه شخصًا مرهف الحس رقيق المشاعر ، فالتناسب بين هـاتين الكلمتين واضـح وقوي، وقد أدى هذا التتاسب إلى تثبيت الفكرة وتركيز المعنى.

(إن معرفة أوجـه التتاسب أمـر لا نستطيع تحديده بقانون، إنمـا يُترَكَك لمهارة الثاعر ، وما تمليه عليه حالته الوجدانية، وذكاؤه الفطري، فالإبداع يتولد داخل الإطار الكمي الثابت حينما يمزج هذا الإطار بعناصر أخرى من الألفاظ 
أثر التصوير البياني والتحسين البديعي هِّ أداء معنى الصفح هٍِ الشعر المهجري: القروي

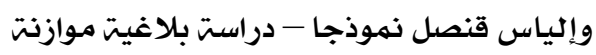

حوليت كليت اللغت العربيت بإيتاى البارود (العدد الثالث والثلاثون)

والمشاعر والخيال) (')

أما مقطوعة إلياس قنصل الثانية فيقول فيها: " أَجِيُْونِي "بَنِي أُمِيّي" عَلَكَا

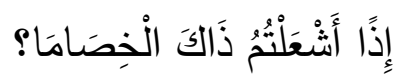

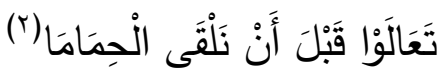

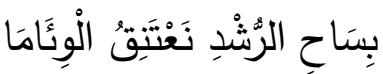

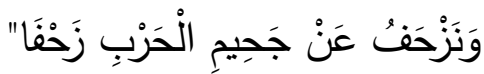

وقد اتفق قنصل في هذه المقطوعـة مـع القروي في استخدامه للمحسنات

البديعية؛ إذ تنوع استخدامه للمحسنات بين الطباق والسجع والتناسب.

فأول ما يلحظه القارئ في هذه المقطوعة: التناسب بين الكلمات الثلاث: "

الْخِصَام - الْحِمَام - الْحَرْب" تتاسُبًا في المعنى والهدف، والتتاسب بينها من فن

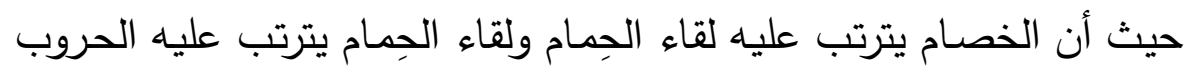

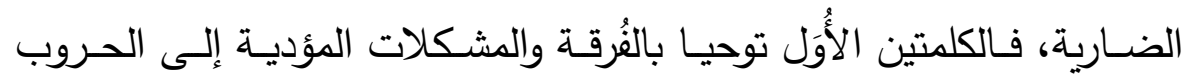

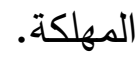

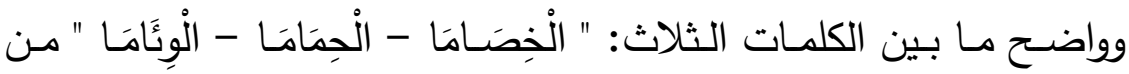

سجع متوازي، وقد أحدث هذا السجع موسيقى جلبة صـاخبة قويـة تناسب ما عليه الثاعر من حالة نفسية سيئة بسبب ما عليه قومه من فرقة وخصام، وقد تعـاون مـع السـجع في إحـداث تلك الموسـيقى المـؤثرة المـدود المتكررة في الكلمات الثلاث؛ إذ تكرر المد بالألف في كل كلمة مرتين في وسطها وآخرها، مما ساعد على تصوير الحالة النفسية التي ألمت بالثاعر أدق تصوير . بلإل ويلاحظ الطباق بين قوله "الْوِيًَامَا" وقوله "الْحَرْبِ"، والطباق يوضـح الفرق بين حالة الوئام والهدوء وما يترتب عليهما وحالة الحرب وما يترتب عليها، فالوئام

(1) الثعر العربي الحديث بين موسيقى العروض والإبداع الفني، محمد فايد هيكل، رسالة

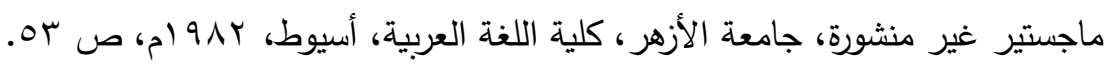

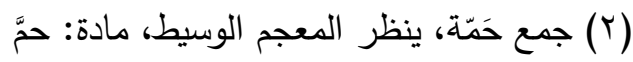


أثر التصوير البياني والتحسين البديعي فِ أداء معنى الصفح هٍُ الشعر المهجري: القروي

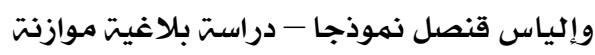

حوليت كليت اللغت العربيت بإيتاى البارود (العدد الثالث والثلاثون)

يُثَعِر بالسـلام والأمسان ويجعل من يشعر بذاك الوئـام في حالة نفسية هادئة

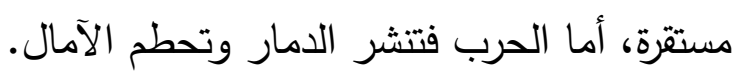

وتأتي المقطوعة الثالثة للقروي؛ إذ يقول فيها: " فرشتُ لكم طريقَ الحبِ زهرا فَلْمز تطأونَ بالبغضاءِ جمرا

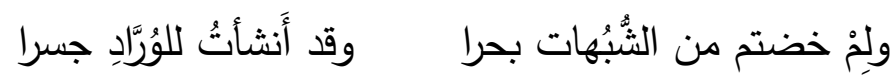

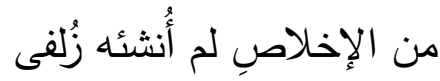

في هذه المقطوعة يستعين القروي بثلاث فنون بديعية للتعبير عن المعنى

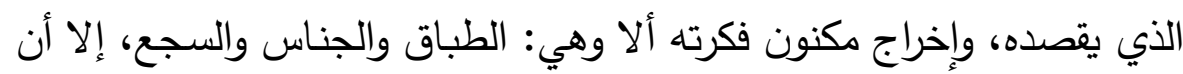
الطباق قد كان له الحظ الأوفر من التحسين في المقطوعة.

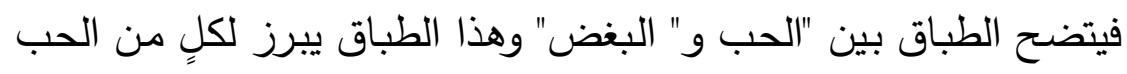
والبغض صورة خاصة به، هذه الصورة لها خطوطها وتقاسيمها المختلفة عن الأخـرى، فالحـب غيـر البغض في تـأثيره؛ إذ الحبب يجلب عطفًا ومـودةًا، والبغض يجلب كرهًا وتتافرًا. وكذا الطباق بين قولـه: "زهرًا وقولـه: " جمرًا"، وقد أضـاف الطباق - بما يشتمل عليه من تضاد في المعنى - صورة واضحة قريبة إلى الذهن لكلٍ من الزهر والجمر، فتأثير الزهر على النفس غير تأثير الجمر ؛ إذ الزهر ينشر البهجة والأمل، والجمر ينشر الكآبة والألم. ويتضح الطباق كذلك بين بحر وجسر، والطباق يوضـح ما لكلٍ من البحر والجسر من خصوصية تميزه عن الآخر، فالبحر من صفاته الغدر والغرق والعمق، والجسر من صفاته الأمن والإنقاذ من الغرق والسطحية.

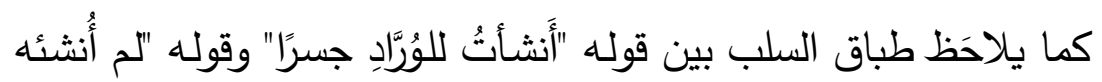

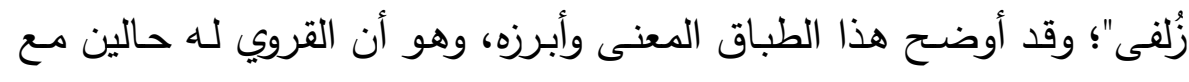

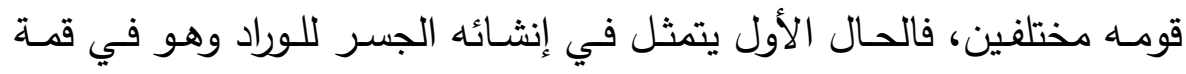
الإخلاص، رغبةً منه أكيدة في إنقاذهم من غياهب الثبهات والثكوك، والحال 
أثر التصوير البياني والتحسين البديعي فِ أداء معنى الصفح هٍُ الشعر المهجري: القروي

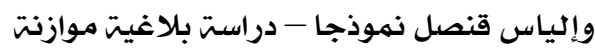

حوليت كليت اللغت العربيت بإيتاى البارود (العدد الثالث والثلاثون)

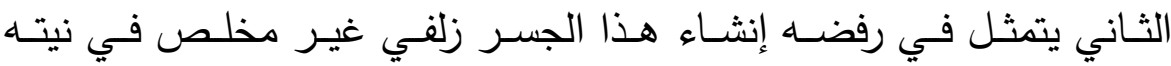
لإصلاحهم، فالفرق بين الحالين شديد والهوة بينهما بعيدة.

ويتضـح كذلك الجنـاس اللاحق بين قوله: " جمـرا" وقولـه: " جسـرا"، كمــا يلاحظ ما بين الكلمات الأربع: " زهرا - جمرا - بحرا - جسرا " من السجع المتوازي، وقد أحدث كلٌّ من الجناس والسجع موسيقى ذات جرس عذب رقبت رهيق يتتاسب والحالة النفسية الهادئة التي يعيشها الشـاعر بسبب سـلامه النفسي، وبلاغة هذا الجرس أنه (يؤثر في النفوس تأثيرًا كالسحر ، ويلعب بالأفهام لَعِبَ الريح بالهشيم، لما يحدثه من النغمة المؤثرة والموسيقى القوية التي تطرب لها

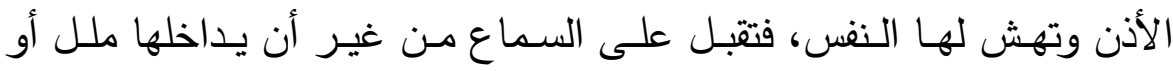

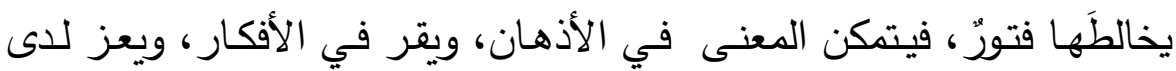
(العقول) (')

وتأتي المقطوعة الثالثَة لقنصل؛ إذِ يقول فيها:" سَمَحْتُ لَكُمْ بِمَا أَجْرَنْتُمُوهُ

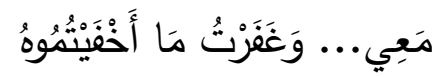

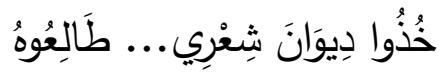

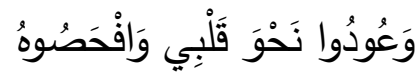

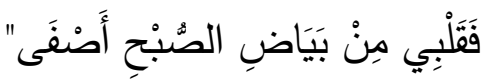
وفي المقطوعـة هذه يلاحظظ تــوع اسـتخدام قنصـل للمحسـنات البديعيـة بـين الطباق والتتاسب والتقسيم. فقد طابق بين قوله: " أَجْرَتْتُعُوه" وقوله: " أَخْفَيْتُمُوهُ " فما أجروه كان في العلن وبهذا يكون ضد ما أخفوه، وقد أوضح هذا الطباق المعنى وأبرزه، وهو صفح قنصل عن أعدائه ومسامحته إياهم وغفرانه لهم كل ما أذوه به، وما سببوه له من مشكلات، سواءً أكان هذا منهم في العلن أو في الخفاء، وواضـح ما بين الحالين من فرق شديد.

(1) الصبغ البديعي، د. أحمد موسى، ط دار الكتاب العربي، ^^ش اهـ. 
أثر التصوير البياني والتحسين البديعي هِّ أداء معنى الصفح فِ الشعر المهجري: القروي

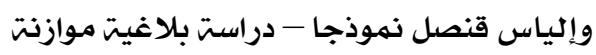

حوليت كليت اللغت العربيت بإيتاى البارود (العدد الثالث والثلاثون)

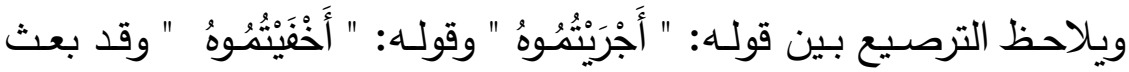

الترصيع موسيقى عذبة رقيقة ناتجة عن التكرار الصوتي في المقطوعة، وهذه الموسيقى تساعد في تصوير ما عليه الثاعر من صفح وتسامح مع أعدائه،

وتعاون القارئ على تخيل هذا الأمر دون أن يداخله ملل، أو يخالطه فتور .

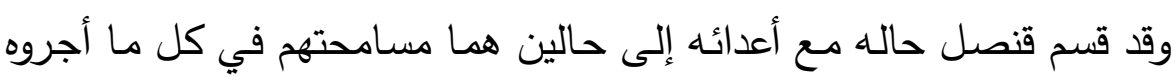
معه في العلن، وغفران لهم كل ما يضمرونها لـه في نفوسهم، فقنصل لم يجد لنفسه حالة ثالثة، وهذا التقسيم يبرز ويؤكد سماحة الثـاعر ومحبته لأعدائه، وأنه لا يحمل لهم أي ضغينة أو كراهية.

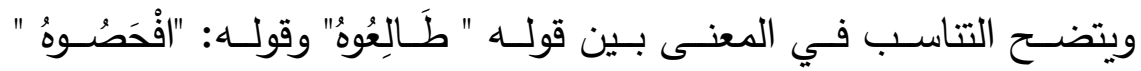
والتتاسب بين الكلمتين يتمثل في أن كلَ منهما يترتب عليه التأكد من صحة

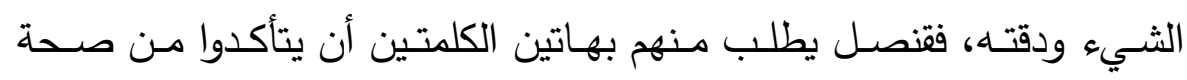
كلامه ونواياه الطيبة

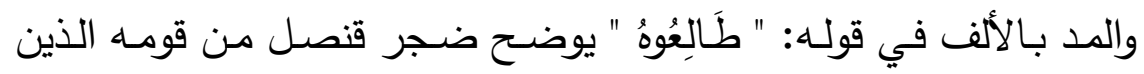
طالما تعبوه وأجهدوه في إثبات حسن نواياه وحبه لهم وتسامحه معهم. وشيوع حرف المـ (الـواو) وتكراره في المقطوعـة، يزيــ تدفق السيل النغدي والإيقاعي المسيطر على المقطوعة، فتنطلق مـع المد، وإطلاق القافية بالفتح

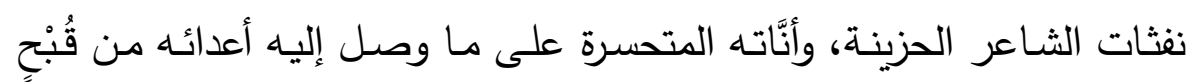
وخُبْثٍ، وتكثف عن رغبات نفسه الملحة، وآماله العظيمـة في تغيير أعدائه وتعديل سلوكهم وتتقية صدورهم من المشاعر السالبة.

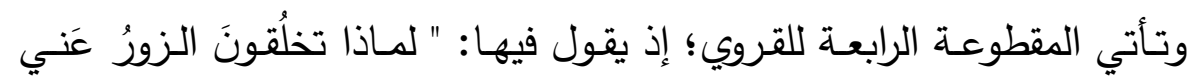
وما هذا التجنبُ والتجنِي أكلُّ جريمتي في الحبِّ أَني إذا أَنشدتُ سُرَّ القوم مني

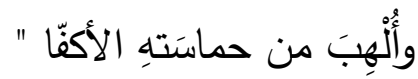


أثر التصوير البياني والتحسين البديعي هِّ أداء معنى الصفح هٍِ الشعر المهجري: القروي

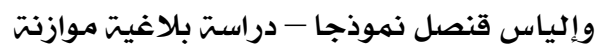

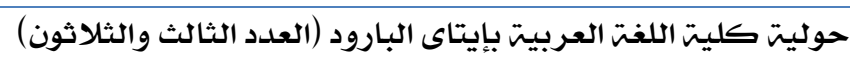

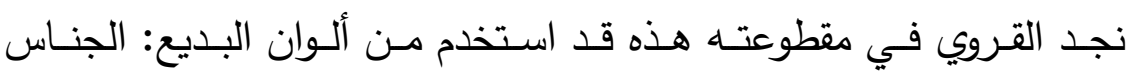

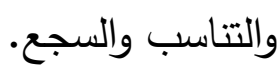

فقد أتى بالجناس اللاحق بيْن قوله "التجنبُ" وقوله "التجنِّي"، إذ الكلمتان اتفتـا في اللفظ واختلفتا في المعنى؛ فـالأولى بمعنى الإقصـاء والإبعـاد، والأخرى لئى بمعنى الظلم، وقد منح هذا الجناس المقطوعة موسيقى عالية قويـة تهز أرجاء المكان وتصور ما بداخل الثاعر من جلبة وضجيج وثورة بسبب الضيق الذي يشعر باه من إقصاء قومده لله وظلمهم إياه.

ويتآزر الجناس اللاحق مـع السجع المتوازي في المقطوعة بين الكلمات:

"عني- أَني - مني"، وقد أحدث هذا جرسا عذبا مؤثرا، ينقل لنا أحاسيس الثاعر المتصارعة بين الألم والفخر، وبين النصر وخيبة الأمل.

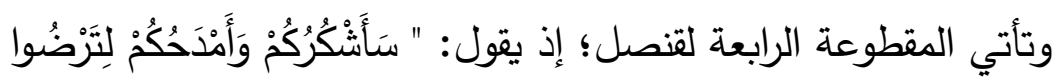

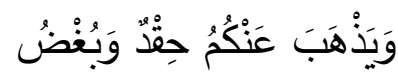

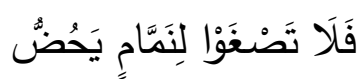

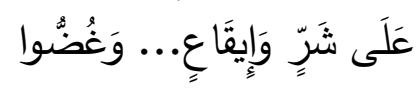

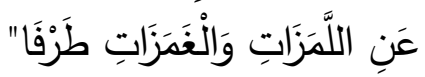

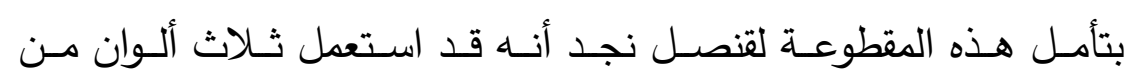

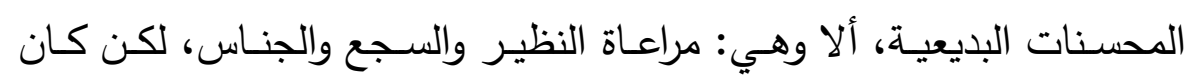

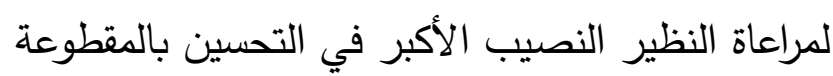

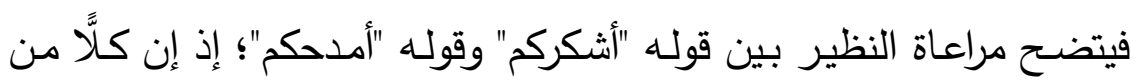
المدح والثكر يُرضي سامعيهما، فكلاهما يؤثر تأثيرًا إيجابيَّا في نفس الممدوح أو المشكور •

وكذلك يوجد مراعاة النظير بين الكلمتين "حقد - بغض"، فهاتان الصفتان ذميمتان تؤذيان من اتصف بهما قبل غيره ممن حقد عليه وبَغَضه. 
أثر التصوير البياني والتحسين البديعي فِ أداء معنى الصفح هٍُ الشعر المهجري: القروي

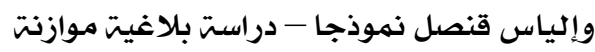

حوليت كليت اللغت العربيت بإيتاى البارود (العدد الثالث والثلاثنانة

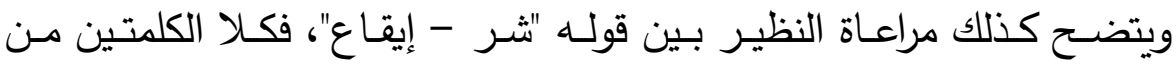

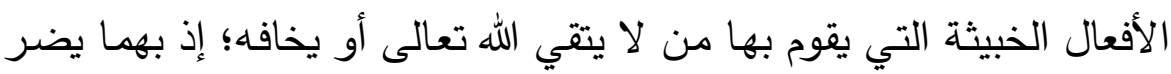

الكثير دون أيَّة جريرة

أو ذنب.

ويـلاحظ السجع المطرف بين قولـه: " تَرَضُـوا" وقولـه: " بُغْضُ"، وكذا السجع المتوازي بين قوله: " يَحُضُّ" وقوله: " وَغُضُُّوا "

ويتضـح كذلك الجنـاس اللاحق بين قولـه: "اللمزات " وقولـه: " الغمزات"، وقد تعاون الجناس مع السجع في بعثِ جَرْسٍ موسيقٍ يتاسب والثدة التي كان

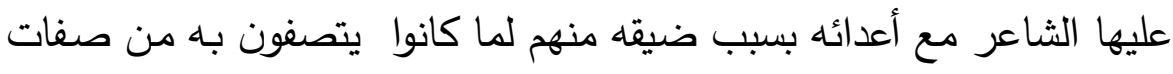
قبيحة، وما كانوا يفعلونه من أفعال خبيثة.

وواضـح ما بين الكلمتين السابقتين "اللمزات -الغمزات"، من التناسب فكلاهما صفة من الصفات القبيحة المنفرة، والتي لا يتصف بهما شخصُ محترم.

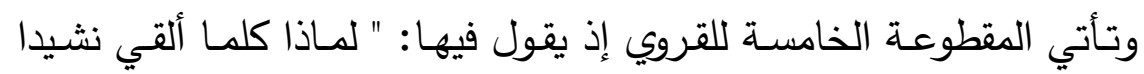

ألاقي منكم سهماً جديداً

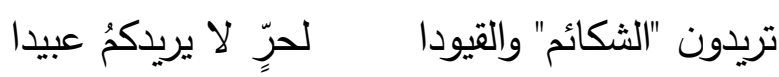

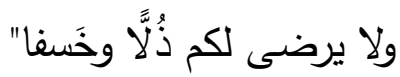

وبـالنظر إلـى هــه المقطوعـة يلاحظظ تــوع اسـتعمال القـروي للمحسـنات

البديعية بين مراعاة النظير والطباق والسجع.

فأول ما يلاقينا من فنون بديعية في المقطوعة: فن مراعاة النظير بين

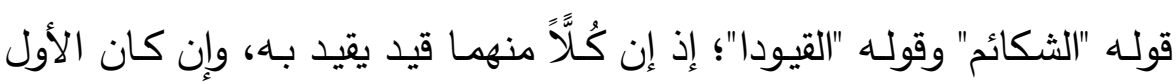

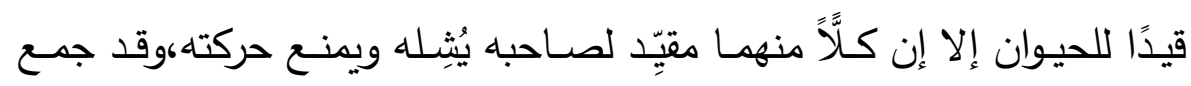
القروي هنا بين القيدين (قيد الحيوان - قيد الإنسان)؛ للإشعار بأن أعداءه قد

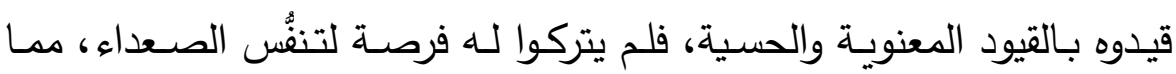
يوحي بأنه كان في حالة شديدة من الضيق والضغط، ولا شك أن القيود أشياء 
أثر التصوير البياني والتحسين البديعي هِّ أداء معنى الصفح هٍِ الشعر المهجري: القروي

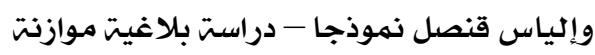

حوليت كليت اللغت العربيت بإيتاى البارود (العدد الثالث والثلاثون)

تزعج الإنسان الحر؛ إذ تشل حركته وتُحمجِم أفكاره.

ويتضـح طباق السلب في المقطوعـة بين قول القروي "تريدون" وقوله "لا

يريدكمُ عبيدًا"؛ إذ جاء أحد الفعلين المتطابقين منفيًّا والآخر مثبتًا، وهذا الطباق قد أبرز المعنى وأوضحه، وهو الفرق الكبير بين حال الثاعر وحال أعدائه،

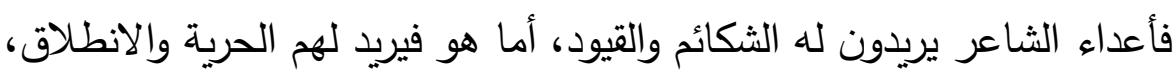
فالبون بينهما شاسع والهوة بينهما بعيدة، فأين العبودية من الحرية! وكذلك طباق الإيجاب بين "حر" و "عبيدًا" يؤكد المعنى السـابق، الذي

تجلى في الفرق الثديد بين رغبة القروي ورغبة أعدائه. ويتجلى فن السجع في المقطوعة بين الكلمات الثلاث: " نشيدا- جديدا عبيدا" وهذا السجع المتوازي قد أضفي على المقطوعة جرسًا موسيقيًا يبث إلينا أنات الثعر وآلامه الثديدة من أعدائه.

والمد بالياء في الكلمات السابقة يوحي بالانكسار النفسي الذي كان يشعر به الثاعر من معاملة أعدائه السيئة له، ومقابلتهم الخير بالثر.

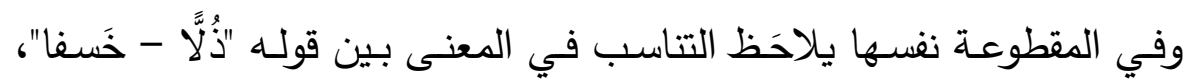

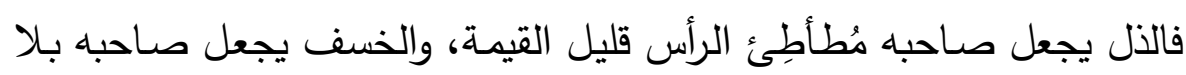
قيمة، بل أحيانًا لا يكون له وجود، إلا أن الذل يجعل صداحبه ينتهي معنويَّا، لئل أما الخسف فصاحبه يمكن أن ينتهي معنويًّا وماديًّا معًا.

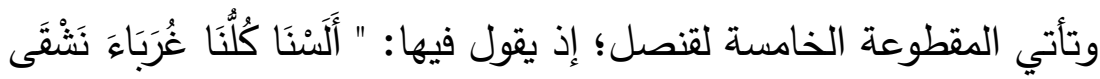

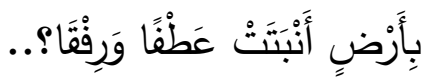

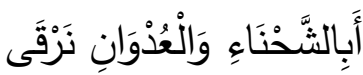

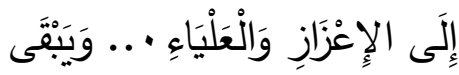

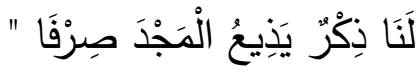
يلاحظ في المقطوعـة هذه لقنصـل انـه قد زاد عن الفنون البديعيـة التي استخدمها في المقطوعات السابقة؛ إذ نجده قد استعمل للتحسين فن التقسيم في 
أثر التصوير البياني والتحسين البديعي فِ أداء معنى الصفح هٍُ الشعر المهجري: القروي

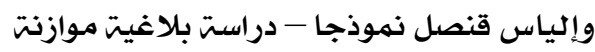

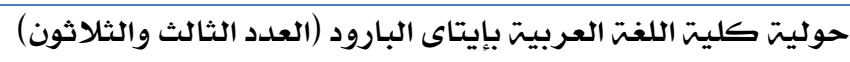

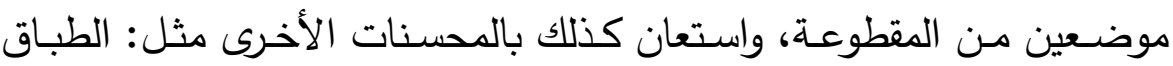

والجناس والسجع والتتاسب أو مراعاة النظير .

أول ما يطالعنا من الفنون البديعية في المقطوعة: فن التناسب أو مراعاة

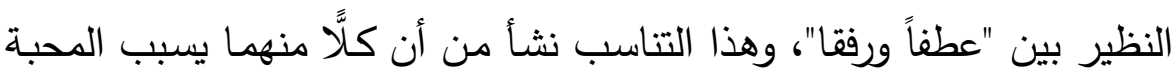

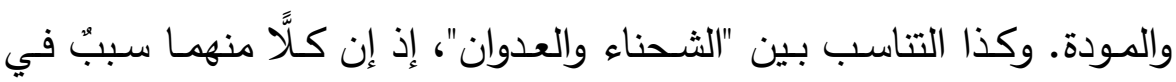

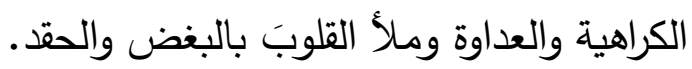

وكـلك التناسـب في الثـطر قبـل الأخيـر في المقطوعـة بـين "الإعْـزَازِ

وَالَْعلْيَاءِ"، فكلُ منهما وسيلة مهمة لتحصيل المجد والكرامة للمره.

وفي المقطوعـة نفسها يطابق قنصـل بين قولـه: "عطف وقوله: " عدوان

"وبين قوله: "رفق " وقوله: " شحناء "، وهذا الطباق قد أبرز المعنى وأوضحهه، لئه

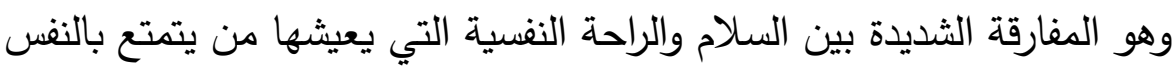
العطوفة ويتخلق بالرفق من ناحية، وبين القلق والاضطراب الذي يحيط بمن يمتلك نفسًا مشاحنةً وسلوكًا عدوانيًا من ناحية أخرى، ولا شك أن الهوة بينها

بعيدة والبون بينهما شاسع.

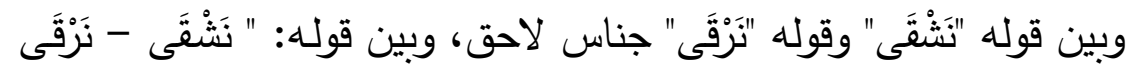

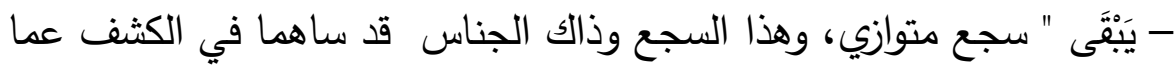

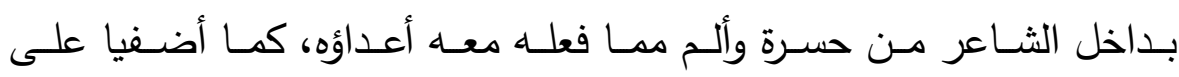

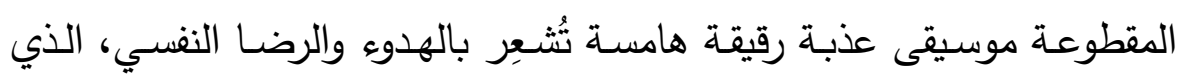
وصل إليه الثاعر بعد صخب وتوتر وقلق.

ويتضح التقسيم في المقطوعة، حيث قسم قنصل ما تتبته أرض الغربة التي

أصبح فيها إلى عطف ورفق فالثـاعر لـ يجد في هذه الأرض من الأخلاق والمشاعر إلا هذين القسمين، مما يكثف عن حزنه الثديد وألمه القوي لافتقاده

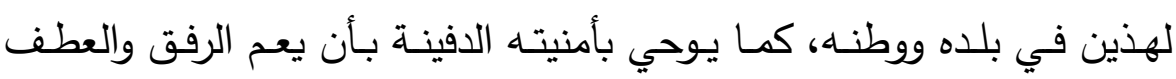
بأرض وطنه كذلك. 
أثر التصوير البياني والتحسين البديعي هِّ أداء معنى الصفح مِّ الشعر المهجري: القروي

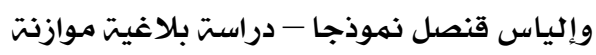

حوليت كليت اللغت العربيت بإيتاى البارود (العدد الثالث والثلاثون)

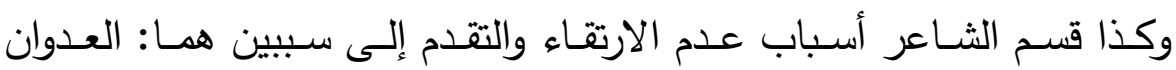

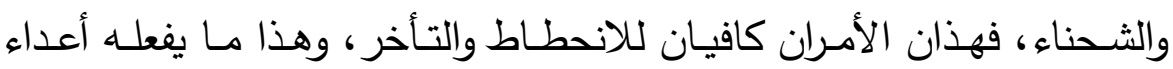

الإسـلام والمسلمين من إيقاع الفرقة والثحناء بينهم، وتحريضهحم على الإغارة

والعدوان على بعض.

هذا وقد أغرم شعراء المهجر الجنوبي بموسيقى حسن التقسيم، وهو

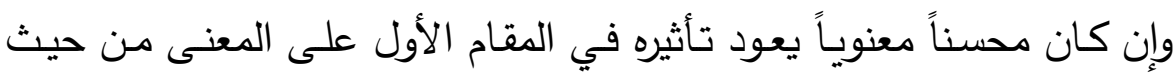
تجليته وإيضاحه، فإنه لا ينكر دوره المؤثر على الصياغة الأسلوبية للألفاظ،

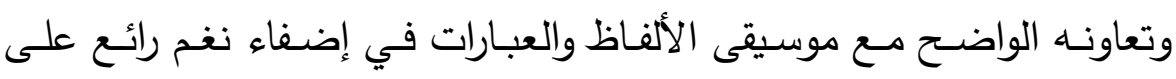
الأبيات يبرز - في كثير من الأحيان موهبة الثـاعر الرائقة، ويصور جانباً الأبعاء مهمًا من جوانب تجربته الثعرية الصادقة. وتأتي المقطوعـة السادسـة للقروي إذ يقول: " أَريشوا وارشقوا قلبي ورأسـي فقد مكّنتُ بالتهذيب تُرسي

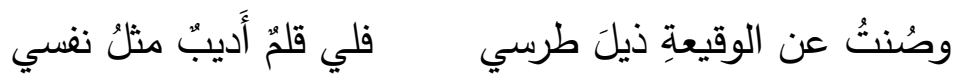
عن القولِ السفيهِ عفا وعفّا " في هذه المقطوعة نلاحظ أن القروي قد استخدم ثلاثة فنون بديعية: التناسب والسجع والجناس.

فالتناسب يتضـح بين قوله: "قلبي " وقوله: " رأسـي"؛ فكلاهما عضو مهم بالنسبة لأي كائن حي؛ إذ لا يستطيع العيش بدون أحدهما، وهذا يوحي بأن

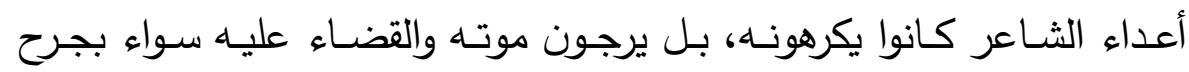
معنوي أو حسي. وقد أسجع القروي فقرات المقطوعة بالكلمات: "رأسي - طرسي - نفسي"، وقد أحدث هذا السجع نغًَا موسيقيًا يتفق مع الحالة التي يشعر بها الثاعر من الشموخ، وفخره بقلمه ونفسه، وقد كان يعتز بهما دومًا وأبدًا 
أثر التصوير البياني والتحسين البديعي هِّ أداء معنى الصفح هٍِ الشعر المهجري: القروي

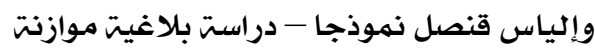

حوليت كليت اللغت العربيت بإيتاى البارود (العدد الثالث والثلاثون)

ثم يأتي الجناس المحرف بين قوله "عفا" وقوله "عفّا"؛ إذ إنهما اتفقا في

اللفظ واختلفا في المعنى، فالأول من العفو والثاني من التعفف، وهذا الجناس قد أعطى المقطوعة موسيقى عذبة أطربت الأذن وهزت الوجدان، ومنحتها جوًا ناعمًا هادنًا قد ناسب الطمأنينة والسكينة، وثقته الثديدة بنفسه وقلمهـ، ويساعد وهد فـي تصــوير ذلــك الجـو، وجـودُ الحـرف المهمـوس (الفــاء) فـي اللفظـين المتجانسين، والذي يشيع الهدوء والرقة ولشفافية.

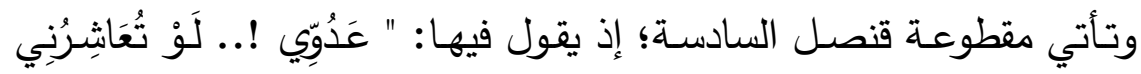

قَلَيلَ

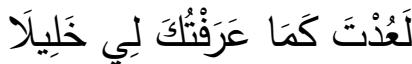

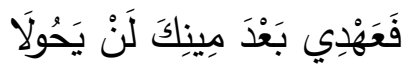

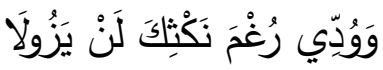

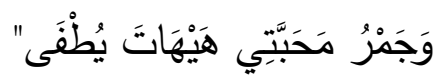

هذا وقد أستعمل قنصل كذلك في هذه المقطوعة ثلاث ألوان بديعية،قد اتفق مع القروي في اثثين منها وهما: الجناس والسجع، وقد تفرد قنصل ب الطباق.

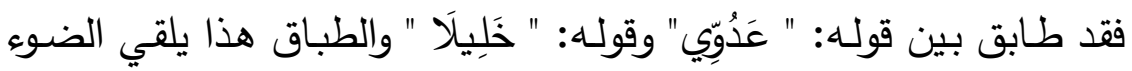
على كلٍّ من المحبة القويـة التي تصل إلى الخلة، والعداوة الثديدة التي تقتل كل المشاعر الطيبة كما يبرز الفرق بينهما، فالبون بينهما شاسع؛ إذ المحبة تجعل المحب يفدي من يحب بالغالي والنفيس، والعداوة تحرك صـاحبها بكل شر إلى عدوه وتحرضه على الانتقام منه. وقد طابق قنصل كذلك بين قوله: " عَهْدِي " وقوله: " نَكْثِكَ "وقد أبرز الطباق الفرق الهائل بين الوفهاء بالعهد ونكثـه؛ إذ الفرق بينهمـا كبير ، كالفرق بين السـماء والأرض، وبـين الحق والباطل، وبـين الأبـيض والأسـود، فالثـخص

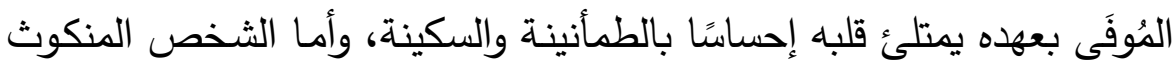
عهده فيمتلئ شعورًا بالفزع والقلق وعدم الأمان. 
أثر التصوير البياني والتحسين البديعي هِّ أداء معنى الصفح فِ الشعر المهجري: القروي

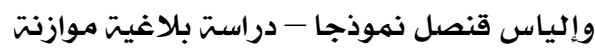

حوليت كليت اللغت العربيت بإيتاى البارود (العدد الثالث والثلاثون)

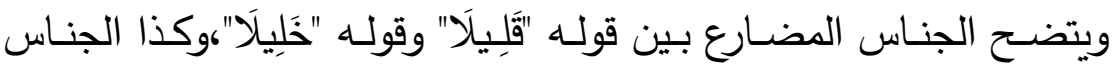

اللاحق بين قوله: " يَحُولَا "وقوله: " يَزْولًَ "، وفي الوقت نفسـه قد أسجع بها

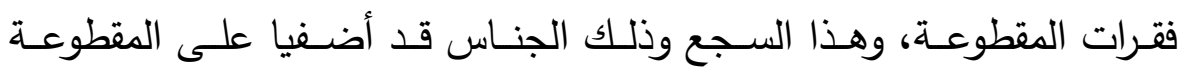
موسيقى عذبة رقيقة ناعمة ساعدت في نشر جو من المحبة والود. ويقـول القـروي في مقطوعتـه السـابعة: " غرســُ الحـبَّ فـي قلبـي صــيرا وأطلقتُ السلامَ به غديرا أُرجع إذ غدا روضًا نضيرا فأَجعله ببغضكمُ سعيرا وأقطف منه جمر الحزن قطفا "

أول ما يلفت الانتباه من فنون بديعية في المقطوعة هو التناسب بين قوله: "الحبَّ " وقوله: "السـلامَ"، وكذا التتاسب بين اللفظتين "غديرًا - روضًا"؛ فكلٌّ من الحب والسلام سبب من أسباب سكينة الشعوب وسعادتها، وشعورها بالأمن والأمـان، وكذا الغدير والروض يلزم عن حضور أحدهما في الذهن حضور الآخر، فلا روض بدون غدير ولا غدير بدون روض، وإن اختلفا في الشكل

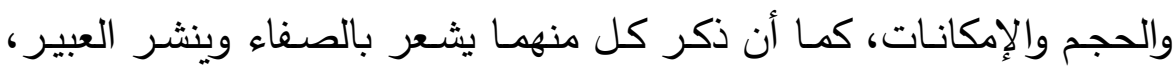
وهذا التناسب قد أدى إلى التركيز في المعنى وتأكيد الفكرة التي يقصدها

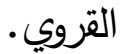

ويـأتي الطباق بـين قولـه: " الحب " وقولـه: " البغض "، وقد أبرز هـذا الطباق المباعدة والمخالفة بين حالة الحب وما عليه صساحبها وحالة البغض وله ومـا عليـه صـاحبها، فـالفرق بينهمـا شـديد والبـون شاسـع كـالفرق بـين الزهـر النضير والجمر السعير ـ كذلك بين قولـه "نضيرا" وقولـه "سعيرا" طباق أبرز

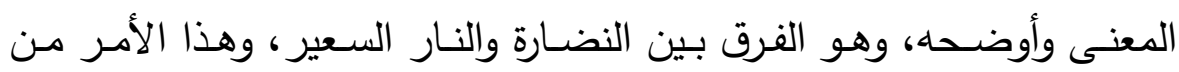
الوضوح بمكان. 
أثر التصوير البياني والتحسين البديعي فِ أداء معنى الصفح هٍُ الشعر المهجري: القروي

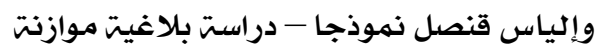

حوليت كليت اللغت العربيت بإيتاى البارود (العدد الثالث والثلاثون)

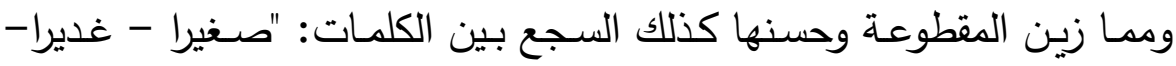
نضـيرا - سـعيرا" فقد أضـفى السـجع على المقطوعـة موسـيقى رقيقـة ناعمـة تتناسب والمعاني التي قد أتى بها القروي. ويقول قنصل في مقطوعته السابعة: " عَدُوِي لَسنَتُ أَرْغَبُ فِي شِقَّاكًا

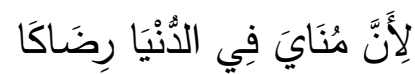

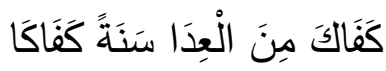

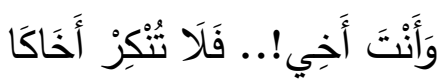

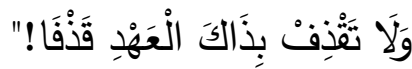
ويلاحظ الطباق بين قوله: " عَدُوِي " "وقوله: " أَخِي "، ويكثف الطباق عن البعد النفسي لكلٍ من الإحساس بالعداوة والإحساس بالأخوَّة، فكلٌ منهما يؤثر

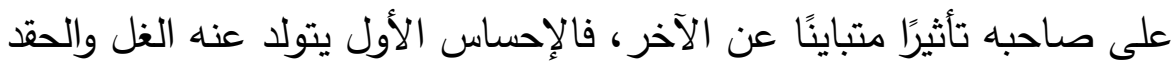

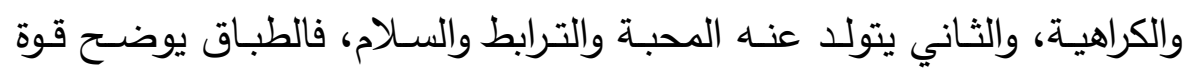

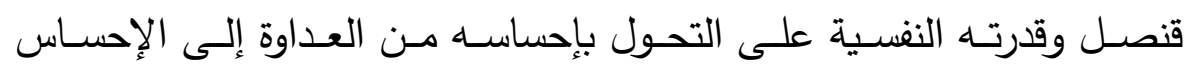

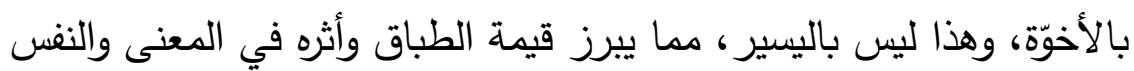

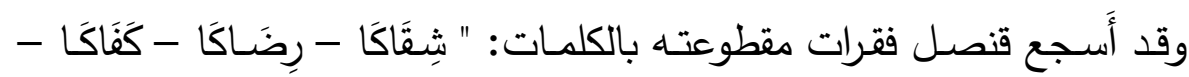
أَخَاكَا" مما أحدث موسيقى مؤثرة في النفس والوجدان. والمد بالألف في المقطوعة يساعد في تصوير طول نفس قنصل وصبره

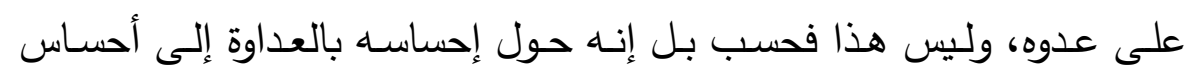
بالأخوة والمحبة، مما يشعر بقيمة الأثر الصوتي وجرسه للألفاظ.

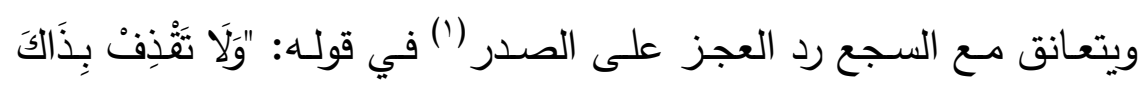

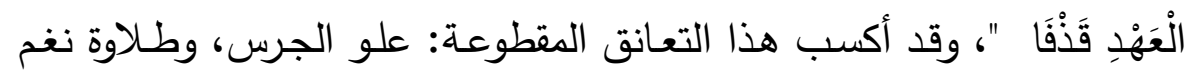

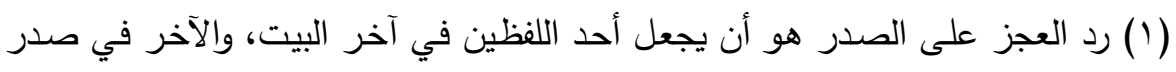

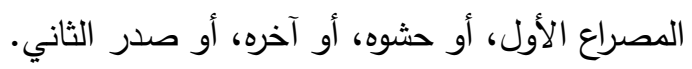

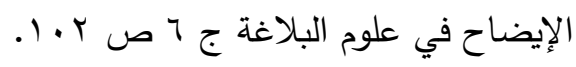


أثر التصوير البياني والتحسين البديعي هِّ أداء معنى الصفح فِ الشعر المهجري: القروي

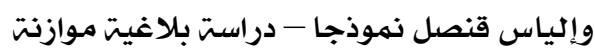

حوليت كليت اللغت العربيت بإيتاى البارود (العدد الثالث والثلاثون)

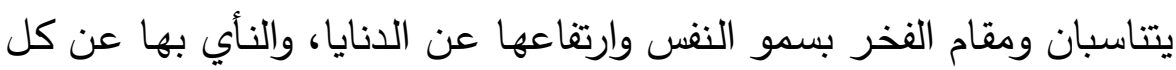
أمراض القلب من حقد وغل وغيرهما من المشاعر السلبية.

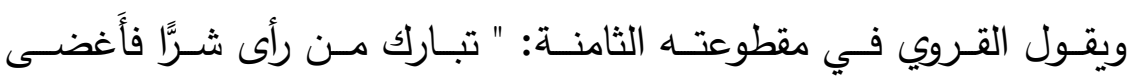
ومن في الحب تُغضبه فيرضى ونى

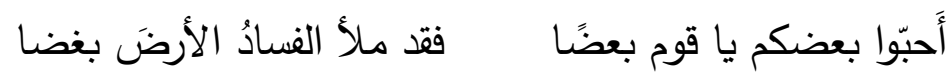

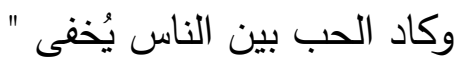
"ففي مقطوعته هذه طباق بين قوله "تغضبه" وقوله "يرضىى"؛ إذ أوضـح الفرق

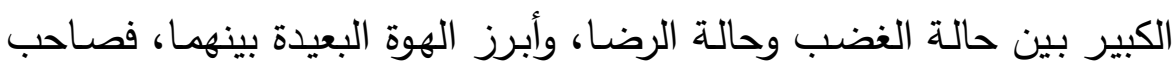
حالة الغضب يختلف تمامًا عن صساحب حالة الرضا، فالأول يصحبه التوتر والقلق والحزن والتشاؤم، والآخَر يصحبه الهدوء والطمأنينة والفرح والتفاؤل. كما يلاحَظ الطباق كذلك بين قوله "أحبوا" وقوله "بغضًا"، وهذا الطباق قد أبرز المعنى وأوضحه، وهو الفرق بين المحبة والبغض وبين من يشعر بهما. ومن الفنون البديعية التي أضفت على المقطوعة جرسًا صوتيًا معبرًا:

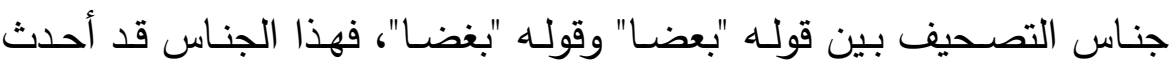
موسيقى جلبة قويـة تتناسب وغضب الشاعر الثديد مما عليه قومها من فساد وبغض وحقد وحسد، دمر حياتهم وحيوات غيرهم، فالحرف الثديد ( الباء ) والحرف المطبق ( الضاد ) يسهمان في الإشعار بالهم الذي أطبق على صدر وحري القروي، والكثف عن كثرته وحدَّته ولا يخفى التناسب بين قوله: " شرَّا" وقوله: " الفسادُ" فكل من الثر والفساد يملأ الأرض بالبغي والحقد والغل. ويقول قنصل في مقطوعته الثامنة: " عَدُوِي لَا تَكُنْ مِنْلَ الْحَسُودِ

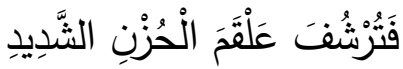

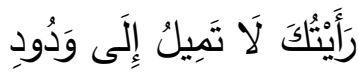

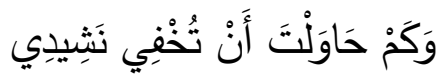


أثر التصوير البياني والتحسين البديعي هِّ أداء معنى الصفح هٍِ الشعر المهجري: القروي

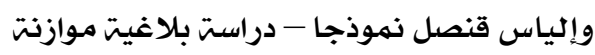

حوليت كليت اللغت العربيت بإيتاى البارود (العدد الثالث والثلاثون)

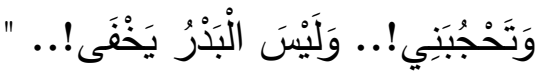

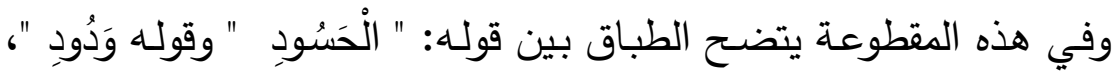

وقد كثف الطباق عن الهوة البعيدة بين الثخصين، فالأول قلق نـاقم على الآخرين يتمنى زوال النعم منهم، والثاني صـافي القلب، هادئ النفس، محب

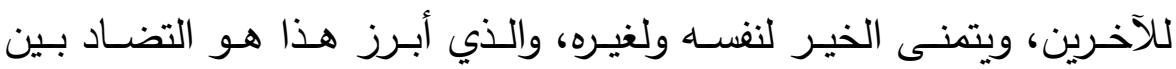
المعنيين

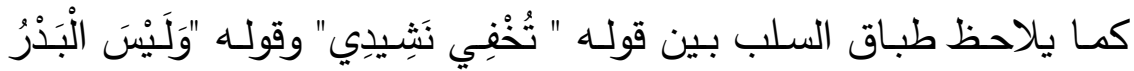
يَخْفَى"، وهذا الطباق يوحي بذيوع أمر الثاعر وشهرته، كما يوضتح نية أعدائه الخبيثة المغرضة التي تريد إخفاء محاسنه ومآثره الجليلة.

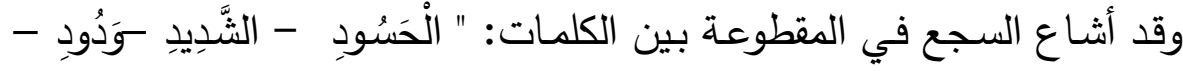
نَثْيِيدِي " موسيقى رائعة ساعدت في الإشعار بحالة قنصل النفسية الناقمة على كل ما حدث من أعدائه من حسد ونكث بالعهود وإخفاء محاسن ومزايا كثيرة لأن نفوسهم تحركها الأهواء والأحقاد

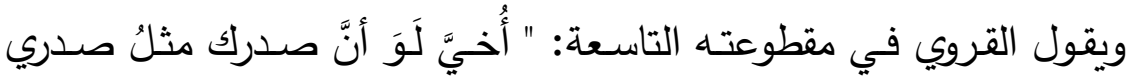
وفكرك في الحياة نظير فكري وجدتَ لكلّ ذنب كلّ عذر وجُدَّ لكل هجّاءٍ بشكرِ وإن هو زاد طغيانًا وعسفا

ويتضــح في هذه المقطوعـة الجنـاس المحرف بـين قولـهـ "وجَدَتَ" وقولـهـ "وجُدتَ"، وهذا الجناس يبعث موسيقى عذبة هادئة تتناسب والجو النفسي الذي كان يشعر به الثاعر من السكينة والطمأنينة في تلك اللحظة، إذ كان يعيش لحظة من الصفاء والروحانية خالصة، ينصح فيها أُخيه في العروبة والوطنية. وقابلَ القروي قوله "وجدتَ لكلّ ذنب كلّ عذر" بقوله "وجُدتَ لكل هجّاءٍ بشكرِ"، والمقابلة كانت أكثر وفاءً بالغرض المراد وأبرز للمعنى المقصود؛ إذ إن الغرض المساق له الكلام هو بيان نفس القروي السوية التي تجد لكل ذنب 
أثر التصوير البياني والتحسين البديعي فِ أداء معنى الصفح فِّ الشعر المهجري: القروي

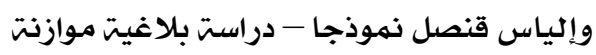

حوليت كليت اللغت العربيت بإيتاى البارود (العدد الثالث والثلاثون)

عذر، وتجود على كل هجاء بشكر ، فلا يقدر على هذا إلا عظيم مثل شاعرنا

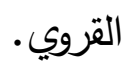

كما يلاحَظ الطباق بين قوله "هجّاءٍ" وقوله "شكرِ"، وقد أبرز هذا الطباق

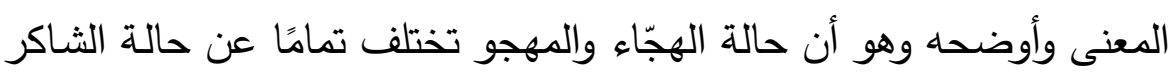
وكذا تأثيرهما على المادح والمشكور ، فالهجّاء يمتلىئ قلبه غـلَّل وغيظًا، وكذا

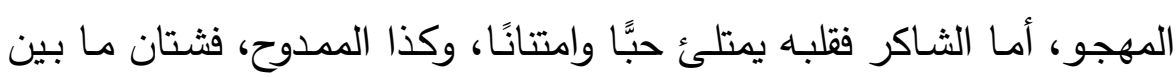

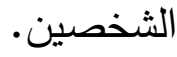
وواضـح ما بين قوله: " طغيانًا " وقوله: عسفا" من تتاسب، فكلُ منهما يولّدّ الإحساس بالظلم والقهر - مأن وتثيع موسيقى السجع بين الكلمات: " صدري- فكري- " نغمًا مطربًا للآذان، بإن ومؤثرًا في النفوس.

وتأتي مقطوعة قنصل التاسعة إذ يقول فيها: " عَدُوِي سَوْفَ يُصْلِحُكَ الزَّمَانُ

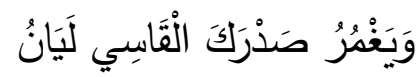

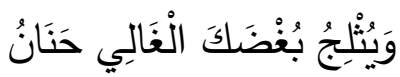

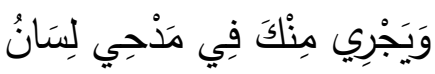

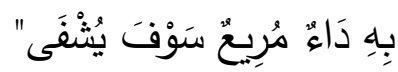
هذه المقطوعـة يتجلى فيها فن الطباق؛ إذ يستخدمه قنصـل في معظم تعبيراته، فالطباق بين قول قنصل: "الْقَاسِي" وقوله "لَيَان"، وهذا الطباق يوضـح ما بين القسوة والليان من فرق بعيد وهوة شديدة، ويبرز أثرهما في النفوس.

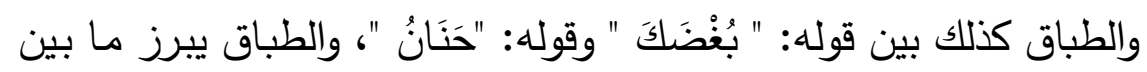
الحالين من تباعد ومفارقة فأثر البغض على النفوس غير أثر الحنان عليها، فالبغض منفر طارد، والحنان مقرب جاذب. 
أثر التصوير البياني والتحسين البديعي ِِّْ أداء معنى الصفح ِِّ الشعر المهجري: القروي

وإلياس قنصل نموذجا - دراست بلاغيت موازنت

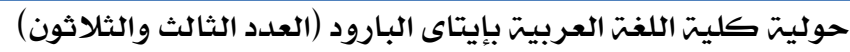

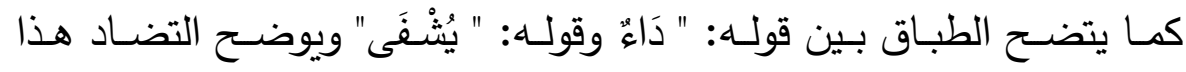
المعنى ويبرزه وهو: التباعد بين الأمرين الداء والثفاء والمفارقة الثديدة بينهما، ولا يخفى على أحد ما بينهما من فروق.

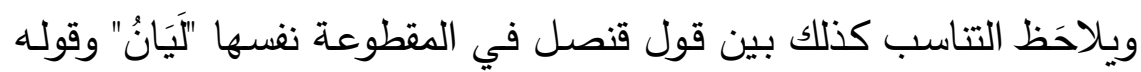

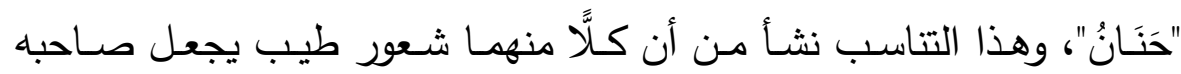

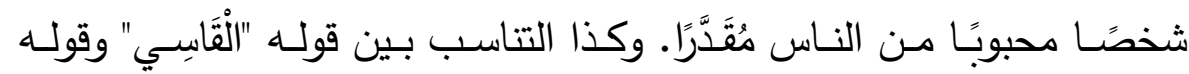

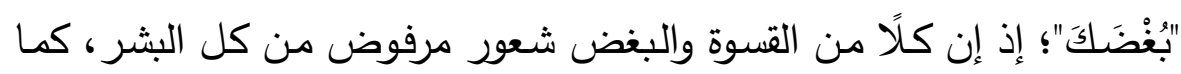
أن كلًا منهما شعور يجعل صاحبه شخصًا ممقوتًا من الجميع ومكروهًا. ويقول القروي في مقطوعته العاشرة: "إذا فكّرتُ في معنى الوجودِ وفزتُ بلمح أَنوار الخلود ودول رثيتُ لكلِّ منتقِم حقودِ يعذّبُ نفسه وأَنا وعودي نروح ونغتدي شدوًا وعزفا " في مقطوعة القروي هذه يتجلى فن السجع بين الكلمات: الوجودِ -

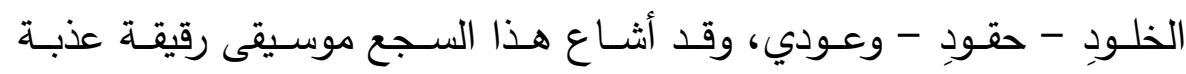
وترنيمات شجية تجلي مشاعر نفس تسعد تحت تأثير الفرح، وتمرح إقبالًا على وعى ولى الحياة وتمسكاً بها. ويتضـح الطبـاق بـين قولـه "نروح" وقولـه "نغتدي"، وهذا الطباق قد أبرز

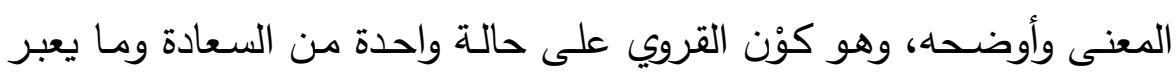
عنها من شدوه وعزفه في هذين الوقتين المختلفين، فمع اختلاف هذين الوقتين لم تتغير حالته التي تتسم بالسرور والإقبال على الحياة، مما يوحي بسـلامته

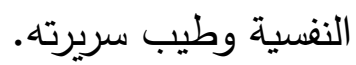

وبين قول القروي "عزفا" في مقطوعته هذه وقوله "عسفا" في مقطوعته التاسعة جناس مضـارع، وهذا الجناس قد أضفي على قصيدته جوَّا موسيقيًّا 
أثر التصوير البياني والتحسين البديعي فِ أداء معنى الصفح هٍُ الشعر المهجري: القروي

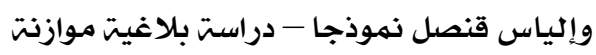

حوليت كليت اللغت العربيت بإيتاى البارود (العدد الثالث والثلاثون)

عذبًا أطرب الأذن وهذا الوجدان، وقد ناسب هذا النغم الموسيقي الحالة النغسية التي كان يمر بها الثاعر حينما كان يكتب هذه الأبيات. ويظهر فن مراعة النظير بين قولهه: " شدوًا "وقولـه: " عزفا"، فكلٌ منهما يطرب الأذن ويؤثر في الوجدان، ومجاورة هذين اللفظين لبعضهها يسهم في

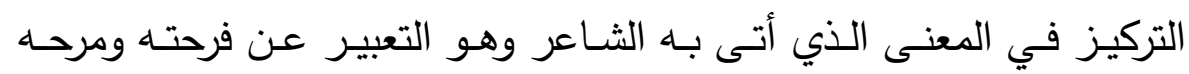

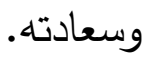

ويقول قنصل في مقطوعته العاشرة: " عَدُوِي إِنْ رَنَوَتُ إِلَى الََّمَاِِ

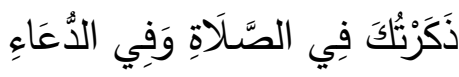

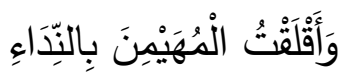
لِينْنُرُ بَعْضَ ذَرَّاتِ الْعَزَاءِ

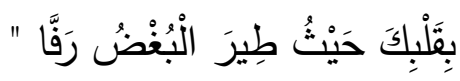

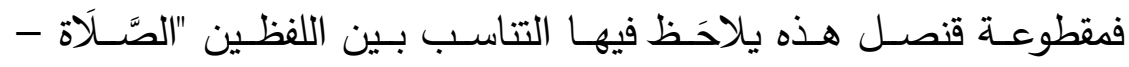

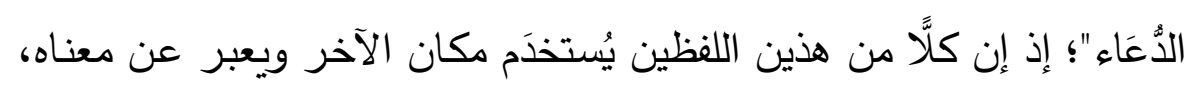
وقد أدى هذا التتاسب إلى تأكيد المعنى وتثبيته، وهو أن قنصل لم يتوقف عن يُن إنى الدعاء بالصلاح لعدوه، وفي هذا من التحبب والتودد ما لا يخفى. ومما نشر في المقطوعة موسيقى رقيقة هادئة السجع بين الكلمات:

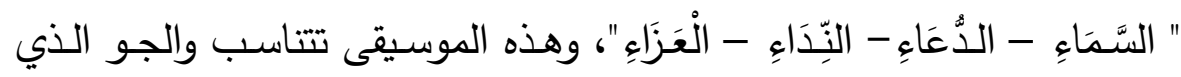

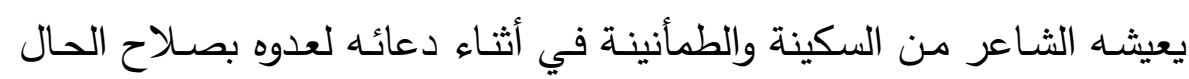
وهو في خلوته مع ربه.

وصفات الحروف وأصـواتها تتآزر مـع السجع في إضفاء هذه الموسيقى، وهي، فالحرف المهموس ( السين ) في الكلمة الأولى ( السماء ) يسهم في تصوير ما عليه الثاعر من ضعف وتذلل لربه وهو ينظر إلى السماء.

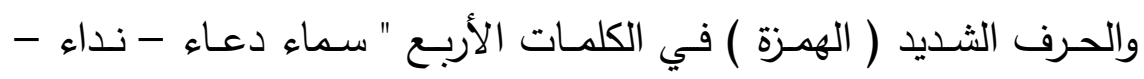
عزاء" يسـاعد في الإيحاء بالجلبة والصـب النفسي الذي يشعر بـه الثـاعر 
أثر التصوير البياني والتحسين البديعي فِ أداء معنى الصفح هٍُ الشعر المهجري: القروي

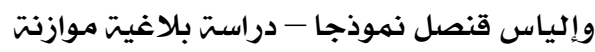

حوليت كليت اللغت العربيت بإيتاى البارود (العدد الثالث والثلاثون)

بسبب ما عليه عدوه من فساد أخلاقي،وبما يحمله في قلبه من مشاعر سلبية للشاعر والآخرين.

ويقول القروي في مقطوعته الحادية عشرة: " رأيتُ الوحش يأنس للأغاني

وصدرَ الريحِ يخفق بالحنانِ

وعشب الحقلِ يبسم عن جُمان ولَمَ أَرَ عابيًا غير الاخانِ

$$
\text { ووجهٍ من رُواءِ الحب جنّا" }
$$

وفي مقطوعة القروي هذه يتضـح طباق السلب بين قوله "رأيتُ الوحش يأنسُ"

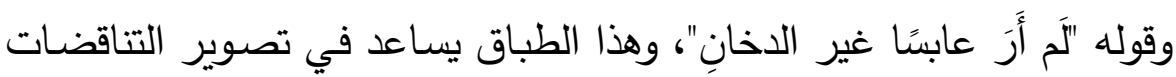
التي كان يراهـا القروي من حولـه، ويوضـح الفرق بين الحالتين: حالـة الفرح والسعادة وحالة الضيق والعبوس، فالفرق بينهما شديد والبون بينهما شاسع. ويتعـانق طباق آخر مـع الطباق السـابق، إذ طـابق الثـاعر بين قولـهـ "الوحش" وقوله "يأنس"، وقد أبرز الطباق المعنى، وهو التوحش الذي يتسم بـ اله

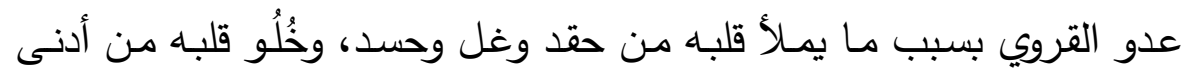
معاني الإنسانية، كما يوضح الإيناس والطمأنينة التي تملأ قلب القروي بسبب ولب وحن مـا عليـه مـن تسـامح وصفح ومحبـة، وقد أبرز الطباق الفرق والهوة البعيدة

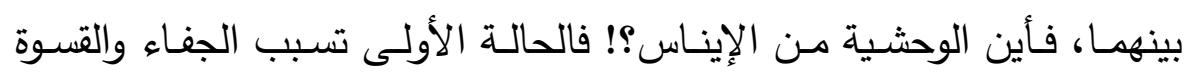

$$
\text { والأخرى تسبب الإيلاف والرِقَّة. }
$$

وكذا الطباق بين قوله " يبسم "وقوله: " عابسًا"، والتضــاد يبرز أثر كلًا من البسمة والعبوس في النفوس، فالرائي للوجها المبتسم غير الرائي للوجها العـابس، فـالأول يحـدث لـه التفـاؤل والانشـراح والثـاني يحـدث لـه التشــاؤم والاكتئاب، فالطباق قد أوضح الفرق والتباعد الثديد بينهما. وقد جمع القروي بين الدخان ومن كـان وجهـه من رواء الحب جف في

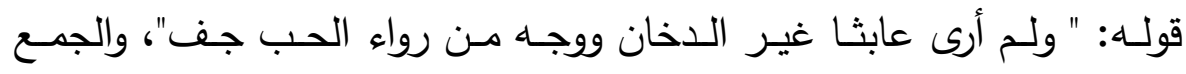
محسن معنوي استخدمه الثاعر ليساوي بين الاخان المؤذي وبين من فرغ قلبه 
أثر التصوير البياني والتحسين البديعي فِ أداء معنى الصفح هٍُ الشعر المهجري: القروي

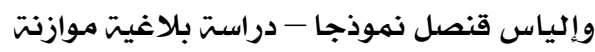

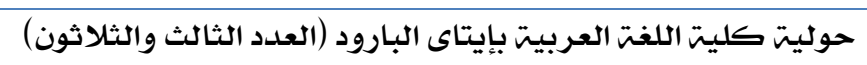

من الحب ومن فقد رواء وجها بسبب جفاف الحب في قلبه، مما يوحي بقيمة الحب وأهميته بين البشر من واء

ويلاحظ التتاسب بـين قولـه:" الحنـانِ وقولـه:" الحب"،فكلا الثـعورين يـأثر

$$
\text { القلوب ويجذبها. }
$$

كما يتضـح السجع المتوازي بين الكلمـات: " الحنـانِ - الدخانِ"، وكذا السجع المطرف بين الكلمتين: "أغاني - جُمان"، وقد أضفى السجع على المقطوعة لئح موسيقى عذبة تتعاون مـع موسيقى الوزن والقافيـة في إحكام القالب النغمي للمقطوعة.

ويقول قنصل في المقطوعة الحادية عشر : "عَدُوِي لَسْتُ أَجْزَعُ حِينَ تَغْضَبْ

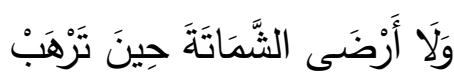

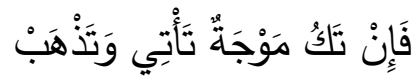

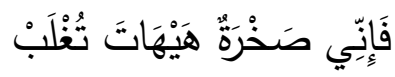

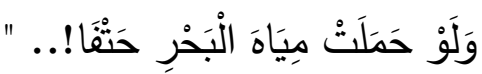

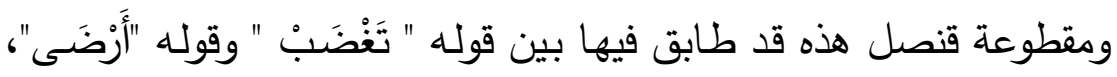

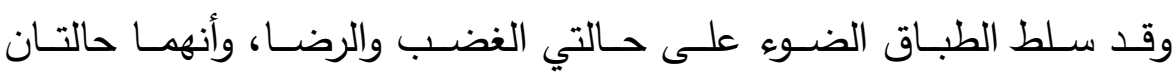

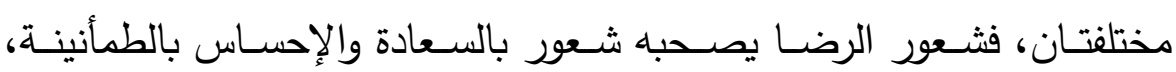
وشـور الغضـب يصـحبه العصبية والإحساس بالهم والضـيق، فالفرق بينهما شديد والهوة بينهما بعيدة.

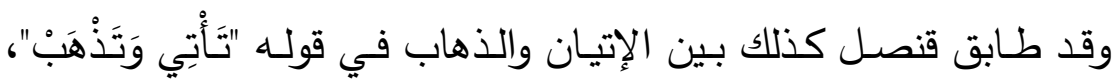
فالطبـاق يوضـح الفرق بـين الحـالين الإتيـان والذهاب، وأنهــا يمثلان الحالـة النفسية بشكليها المختلفين اللذين يمكن أن يكون عليهما عدو الثـاعر، فهو متأرجح قلق غير مستقر وليس مطمئنًا.

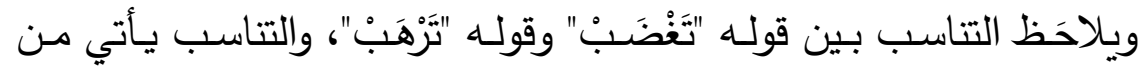
أنهما ينبعان من شعور واحد، هو الانزعاج والقلق والاضطراب. 
أثر التصوير البياني والتحسين البديعي هِّ أداء معنى الصفح هٍِ الشعر المهجري: القروي

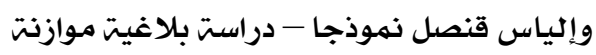

حوليت كليت اللغت العربيت بإيتاى البارود (العدد الثالث والثلاثون)

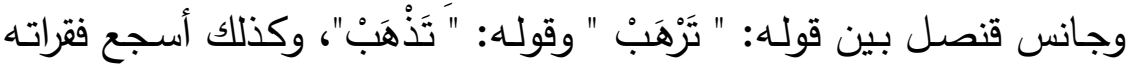

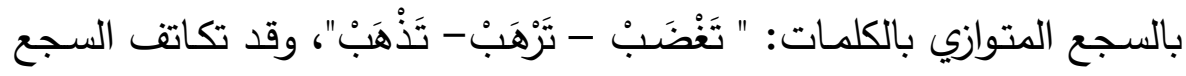

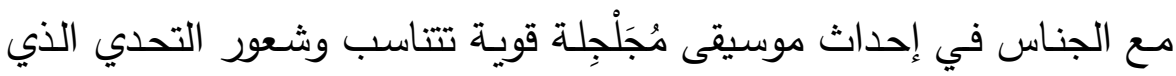

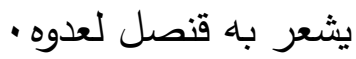

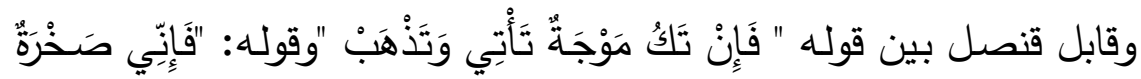
هَيْهَاتَ تُغْلَبْ"، فقد قابل الثاعر حاله من ثبات انفعالي وهدوه بحال عدوه من توتر وهياج، والمقابلة كانت سببًا للوفاء بالمعنى وتمامًا للغرض المقصود، وقد رمز قنصل بالصـرة لشموخه وقوته وتماسكه، ورمز بالموجة لضعف عدوه وقلة حيلته وتفاهته، وقد أظهرت المقابلة لين الشاعر وتسامحه، وتجني عدوه وحقده، فبالمقابلـة تتـوالى الكلمـات في المقطوعـة محدثـة إيقاعـات موسـيقية متشابهة، ونغمات صوتية متقاربة تؤثر في الوجدان. وتأتي مقطوعة القروي الثانية عشر؛ إذ يقول فيها: "عدوِي زوِّد العينينِ نورا ستُمسي مثلما أُمسي ضريرا

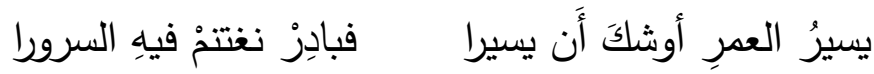
شقينا نصفَه فلنهنَ نصفا" ففي هذه المقطوعة يطابق القروي بين قوله: "نورا وقوله: ضريرا "

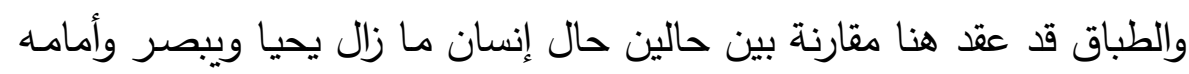
الفرص للاستمتاع بحياته بدون أحقاد ومشاكل، وإنسان قد فارق الحياة وأصبح أعمى في قبر وقد ضاعت منه الفرص وليس لديه أي حيلة للعيش بأي شكل،

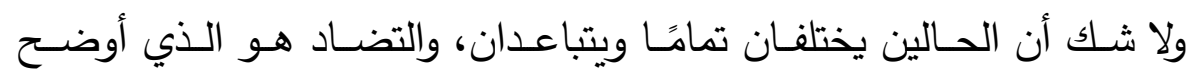

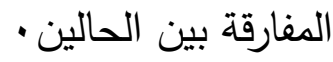

وقد طابق الشاعر كذلك بين قوله: " السرورا " وقوله: " شقينا "، والطباق يوضح الهوة البعيدة والفرق الثديد بين السرور أو السعادة، والثقاء ولا يخفى على أحد الفرق بينهما، وقد أتى الثاعر بالمتضادين ليبرز نعمة السعادة التي 
أثر التصوير البياني والتحسين البديعي فِ أداء معنى الصفح هٍُ الشعر المهجري: القروي

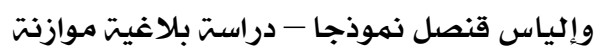

حوليت كليت اللغت العربيت بإيتاى البارود (العدد الثالث والثلاثون)

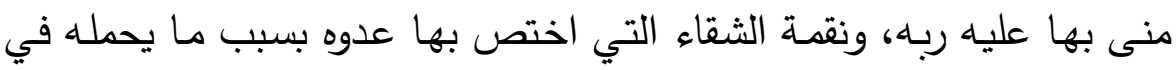
قلبه من ضغائن وأحقاد.

ويتضح الترصيع في المقطوعة بالكلمات: " نورا - ضريرا - السرورا "، وقد

أشاع هذا الترصيع في المقطوعة جرسًا موسيقيًا يساعد في التعبير عن حال القروي من الهدوء والطمأنينة التي تعمه وهو ينصح عدوه بالتخلي عن العادات السيئة وأحقاده.

ويلاحظ تكرار بعض الألفاظ في المقطوعة " ستُمسي - أُمسي" وقولهـ: "

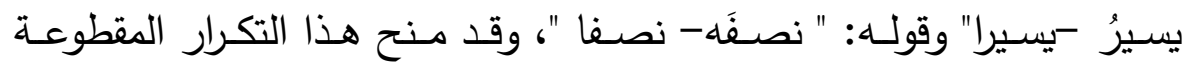
موسيقى تعاونت مع الموسيقى التي أحدثها الترصيع في جعل المعنى أكثر صدقًا وتأثيرًا، وتعتمد هذه الموسيقى المؤثرة على التماثل أو التشابه في الثكل والاخـتلاف في المعنى "أي الاتفـاق بـين وحـدتين صـوتيتين في الإيقـاع والاختلاف في الدلالة، وهنا يكون الاتفاق بين اللفظين كاملًا أو في وجه من الوجوه مع الاختلاف في المعنى".(').

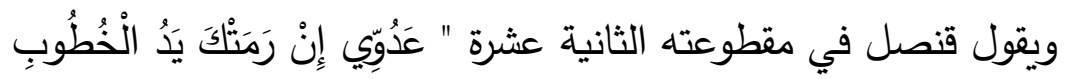

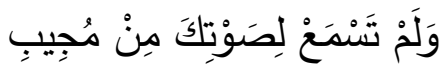

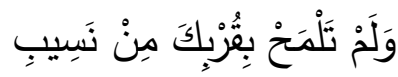

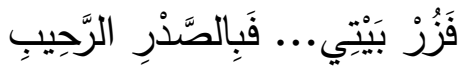
"أُقَابِلْ مَنْ يَكُنْ لِلْخَطْبِ هَذْفَا!...

ففي المقطوعة هذه يتضح الجناس الناقص بين قوله:" الْخُطُوبِ " وقوله: "

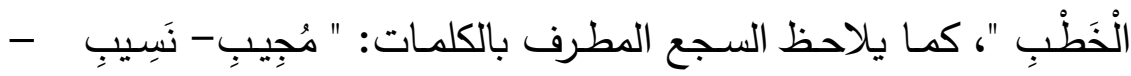
الرَّحِيدٍ"، وقد تكاتف الفنين في المقطوعـة لإحـداث موسيقى عذبـة تطرب الأذن، وتؤثر في الوجدان، وتمنح المعنى قوةً وتأثيرًا.

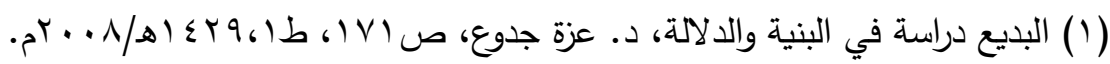


أثر التصوير البياني والتحسين البديعي هِّ أداء معنى الصفح هٍِ الشعر المهجري: القروي

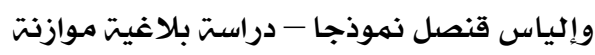

حوليت كليت اللغت العربيت بإيتاى البارود (العدد الثالث والثلاثون)

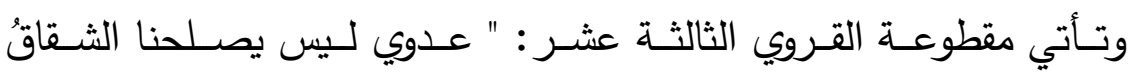

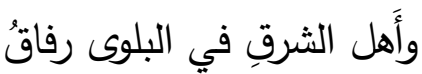

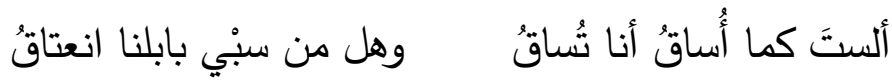

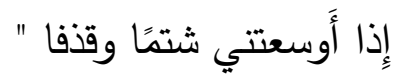

وفي المقطوعـة هذه نلاحظ تكراره للكلمـة: " أُسـاقُ -تُسـاقُ"، ممـا

أحدث نغمًا موسيقيا أمتع القرو والسامع، فقد أعطى التكرار الصوتي إيقاعات هادئة رتيبة تلائم دفقات الثاعر العاطفية والانفعالية، فالأبيات جاءت نتيجة

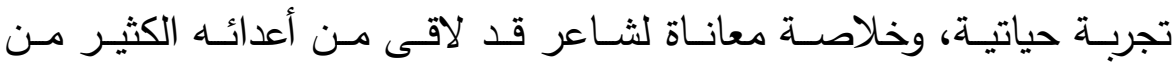
المشكلات، فهو يسدي النصائح، ويلقي الإرشادات لعدوه عَلَّها تحقق الغايات، وينظر إليها بعين العظة والاعتبار •

وقد آزره في ذلك ترصيع المقطوعة بالكلمات المتوافقة صوتيًا وهي على

الترتيب:" الشقاقُ - رفاقُ - تُساقُ - انعتاقُ " مما يضفي نغمًا موسيقيًا عذبًا

يطرب النفس ويهز الوجدان.

ويتضـح التناسـب بـين قولـه "شـتمًا" وقولـه "قذفا"؛ إذ إنهمـا يعطيـان

معنى السب والإيذاء باللسـان، إلا أن الثانيـة أقوى وأثد في الإيذاء، فالقذف أشد من الثتم على النفس وأوجع، وهذا التتاسب قد أدى إلى تأكيد المعنى وتثبيته في النفس، وهو معاناة القروي الكبيرة من أعدائه وألسنتهم. ووجود الحروف المهموسة (الصـاد والسين والثين) وتكرارها يساعد في ماتي تصوير ما عليه القروي من إحساس بالضعف والهوان أمام القوى الإلاهية في الوقت الذي لا يتعظ فيه عدوه ولا يتوقف عن شتمه وقذفه.

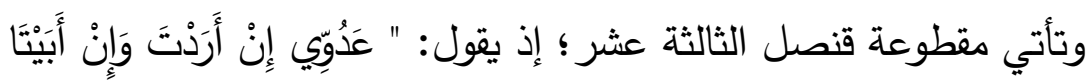

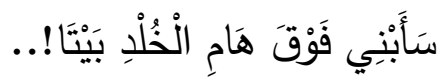

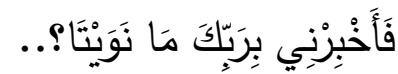

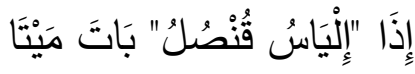


أثر التصوير البياني والتحسين البديعي فِ أداء معنى الصفح هٍُ الشعر المهجري: القروي

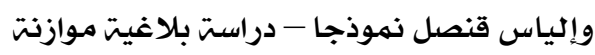

حوليت كليت اللغت العربيت بإيتاى البارود (العدد الثالث والثلاثون)

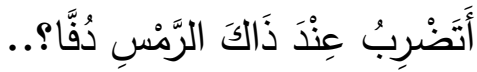

وشيوع حروف الهمس في مقطوعة قنصل هذه لك ( التاء والسين والصساد)

تساعد في رسم الصورة الحقيقية لعدو قنصل من الضعف والتفاهة، في الوقت الذي يثعر قنصل فيه بالقوة والقدرة على التحدي لعدوه، وكأنه استخدم هذه الأحرف متعمدًا ليظهر حقارة عدوه ووضاعته.

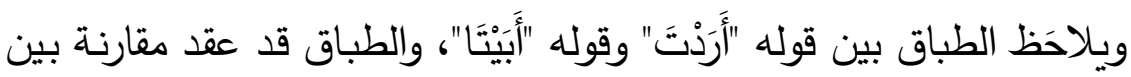
شخصين: شخص يريد شيءً وآخر يرفضه ثم أبرز الحالة النفسية لكل منهما،

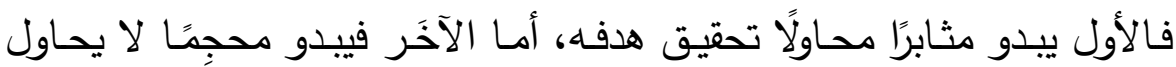
الإقـدام، ومـع الاختلاف الواضــح بينهمـا إلا أن الثـاعر يراهمـا شـيءً واحدًا

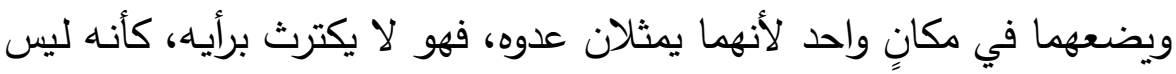

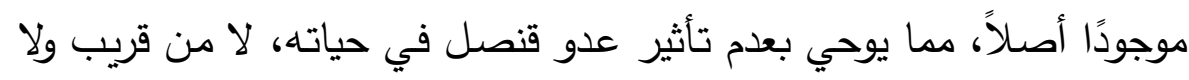

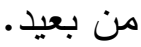

وقد جانس قنصل بين قوله: " أَبَيْتَا "وقوله: " بَيْيًَا"، وكذا جانس بين قوله:

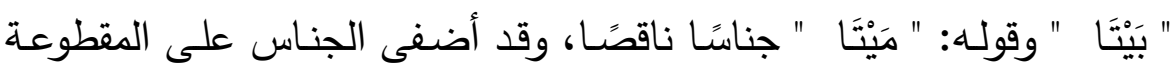
موسيقى طربت لها النفس وتأثر بها الوجدان.

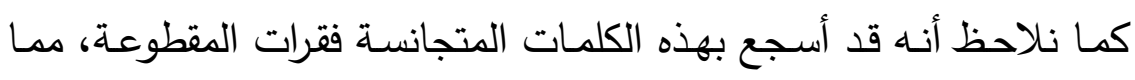
جعل النغم الموسيقي للمقطوعة أكثر تأثيرًا وإمتاعًا. ويقـول القـروي في مقطوعتهـه الرابعـة عشـرة: "ولـو هـذا التحبُّب للغريـبِ بذلنا بعضه لأخ قريبٍ

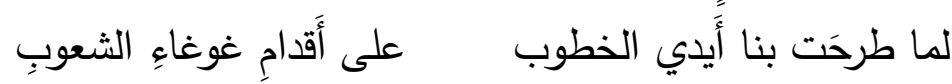
كُرَى تنتابها حذفًا وقذفا " وفي مقطوعة القروي هذه يلاحَظ الطباق بين قوله "غريب" وقوله "قريب"، والطباق يبرز الفرق بين القريب والبعيد، فالقربب يجب أن يُعنى بثأنه ويهتم

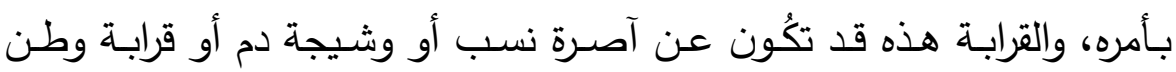


أثر التصوير البياني والتحسين البديعي هِّ أداء معنى الصفح مِّ الشعر المهجري: القروي

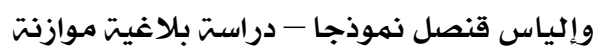

حوليت كليت اللغت العربيت بإيتاى البارود (العدد الثالث والثلاثون)

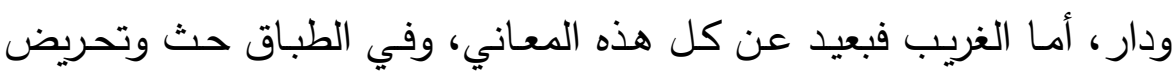

على الاهتمام بالقريب والاعتناء بأمره، وإيثاره على الغريب.

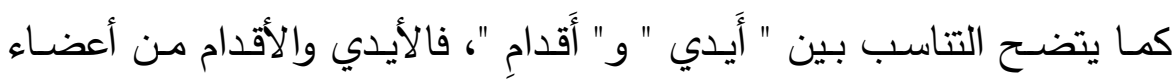
الجسـ المهمـة، ولا تغني إحداهما عن الأخرى، وهذا التتاسب يبرز تكاتف الخطوب وغوغاء الثعوب على الأمة الضعيفة المتفككة. ويـأتي الجنـاس اللاحق في المقطوعـة نفسها بين قولـه: "حذفًا" وقولـه: "قففًا"؛ إذ اتفقت الكلمتان في عدد الحروف وترتيبها وهيئتها واختلفت في نوع

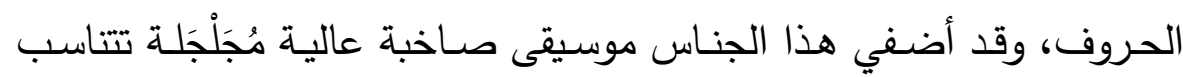
والموقف الجلل، وهو تلاعب غوغاء الشعوب بالأمم الضعيفة المتفككة غير هدوفي

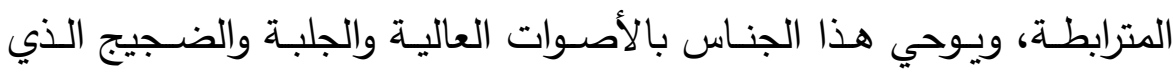
يحدثه هذا القذف وذلك الحذف.

ويتكاتف مع الجناس في إضفاء تلك الموسيقى السجع المتوازي بين قوله: "غريِب" وقوله: " قريبِ"، وكذا بين قوله: " الخطوب" وقوله: "الثُعوبِ".

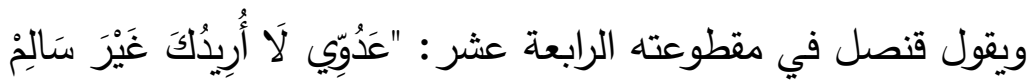

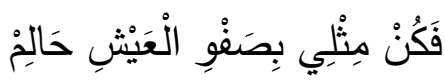

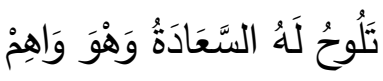

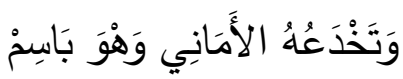

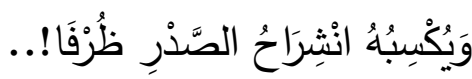
وفي مقطوعـة قنصل هذه يتضـح الجناس اللاحق بين قولـه "سَالِِمِ" وقولـه

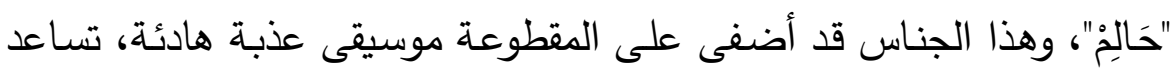
في تصوير الحالة النفسية التي أرادها الثاعر لعدوه من الهدوء والصفاء. وقد تآزر مع الجناس في إحداث ذلك النغم الموسيقي السجع بين الكلمات:

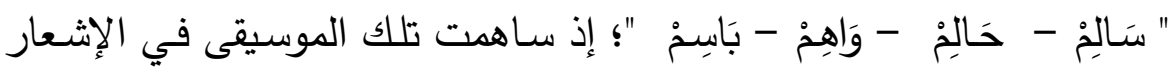
بالسلامة والهدوء والطمأنينة والسعادة التي يتمناها قنصل لعدوه. 
أثر التصوير البياني والتحسين البديعي هِّ أداء معنى الصفح هٍِ الشعر المهجري: القروي

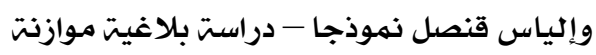

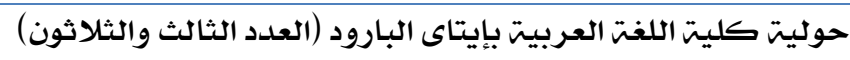

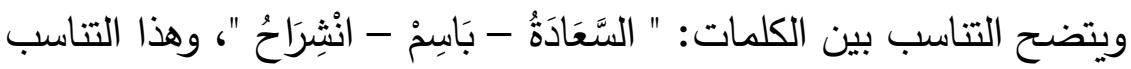

ينشر الفرح، ويشيع الأمل.

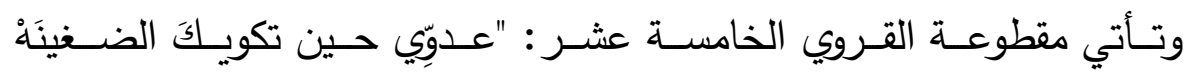
فبادز بالتِرار من المدينَهْ

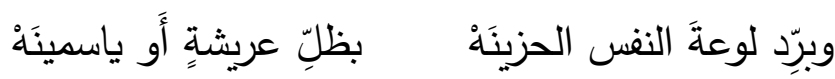

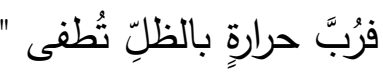

ففي المقطوعة يلاحَظ التتاسب بين قوله "برد" وقوله "ظل"، فهما ينشران الظل والراحة بعيدًا عن الحرارة والهجير ، وهذا التناسب يلقي ظلالًا من النقاء والراحة

النفسية التي يتمتع بها كل من يستظل بهذه العريشة أو تلك الياسمينة.

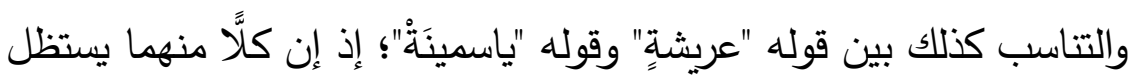
بـه في الهاجرة من الحر الثديد، ووجود هاتين الكلمتين في المقطوعة يشيع النقاء والهدوء والبهجة وينشر الأريج العطر والعبير الطيب.

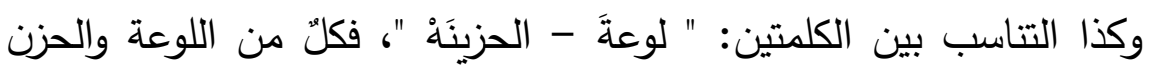
يسببان الألم والأسى للمصاب بهما.

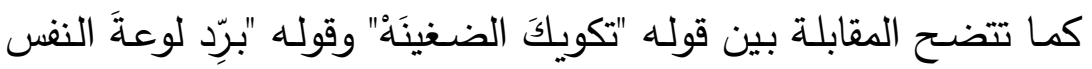
الحزينَهْ"، وقد كانت المقابلة هنا سببًا للوفاء بالمعنى، وإتمام للغرض المقصود، وهو: ضرورة التخلص من الغل والحقد والحسد، وكل المشاعر السلبية. ويتعاون الطباق مـع المقابلة السابقة في إبراز المعنى وإيضـاحه، إذ طابق بـين قولـه "حـرارةٍ وقولـه "ظـل"، وهـذا الطبـاق يلقـي الضـوه على شخصـين مختلفين متتاقضين: شخص متصـالح مع نفسـه راض عن حاله، لا يحمل في قلبه حقدًا أو ضغينة لأحد، وشخص آخَر متخاصم مـع نفسـه غير راض عنها ولا عن غيره، يمتلئ قلبه حقدًا وغلَّا للآخرين ويشتاط غيظًا دائمًا، وقد أبرز الطباق ذلك المعنى وأكده. 
أثر التصوير البياني والتحسين البديعي فِ أداء معنى الصفح هٍُ الشعر المهجري: القروي

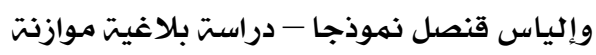

حوليت كليت اللغت العربيت بإيتاى البارود (العدد الثالث والثلاثون)

وقد أطربنا الجرس الموسيقي النابع من الترصيع في المقطوعة، والذي يتضح

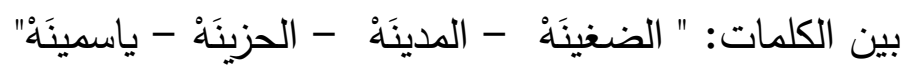

ويقول قنصل في مقطوعته الخامسة عشر : "عَدُوِي إِنَّ لِي أُمَّاَ حَنْونَهْ

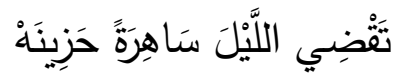

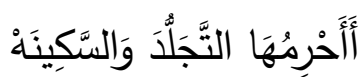

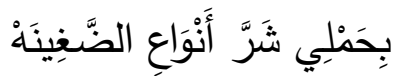

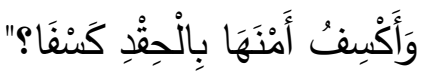

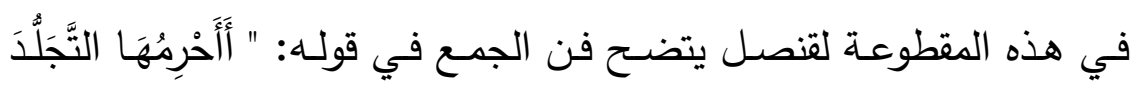
وَالسَّكَينَهُ" حيث جمع بين التجلد والسكينة في حكم واحد، وهو استتكار قنصل

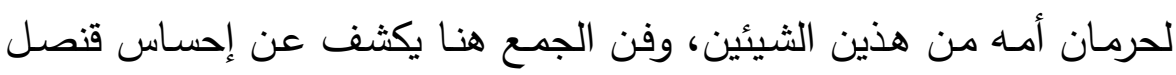

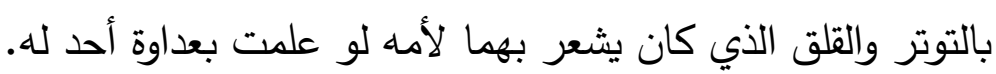

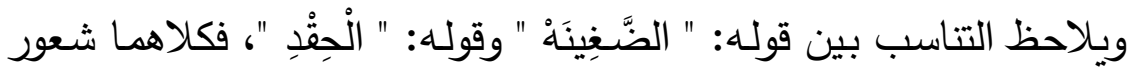
يأكل في صاحبه ويضره هو قبل غيره.

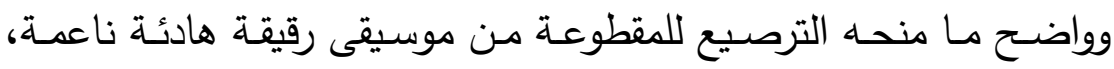

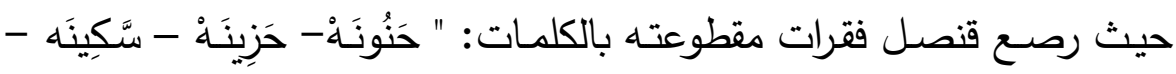

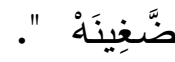

وشيوع حروف الهمس في المقطوعة لك (الحاء والسين والثين والهاء) يؤازر الترصيع في رسم حالة الثجن والقلق التي ألمت بأم إلياس قنصل في غيابه،

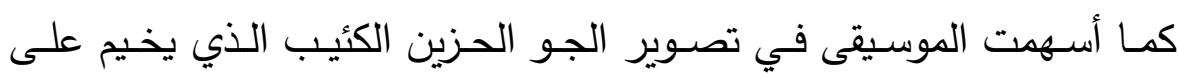

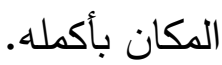

ويقول القروي في مقطوعته السادسـة عشر : " إذذا فَيْضُ المحاسن راعَ قلبَا

تدفّق منه إحساسًا وحُبَّا

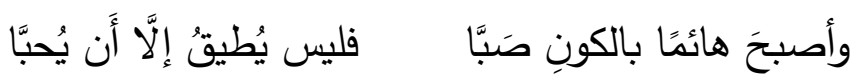

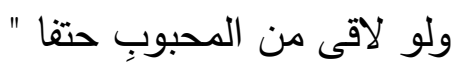


أثر التصوير البياني والتحسين البديعي فِ أداء معنى الصفح هٍُ الشعر المهجري: القروي

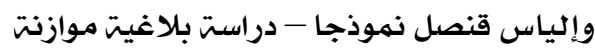

حوليت كليت اللغت العربيت بإيتاى البارود (العدد الثالث والثثلاثون)

ومقطوعة القروي هذه يتضح من خلالها التناسب بين قوله "إحساسًا" وقوله

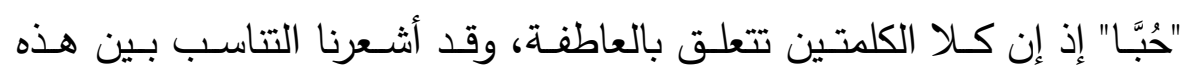

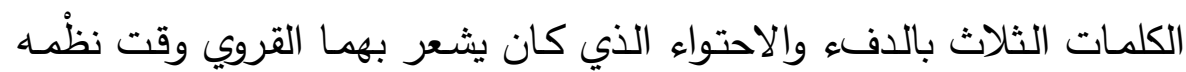
هذه المقطوعة.

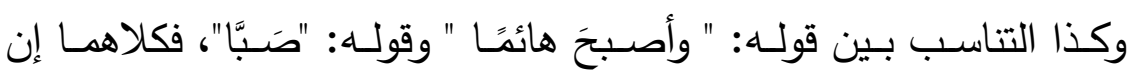
أصيب المرء بهما تاه عقله وانشغل قلبه وسُلِبت إرادته.

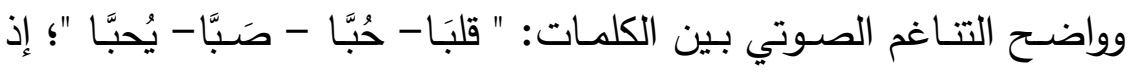
رصع القروي بها فقرات مقطوعته، مما نشر موسيقى رقيقة عذبة تمنح النفس شعورًا بالدفء والاحتواء. ويقول قنصل في مقطوعته السادسة عشر : " إِذَا عَلمَتَتْ بِأَنْي لِي خُصُومُ

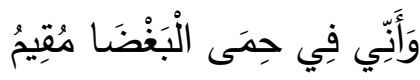

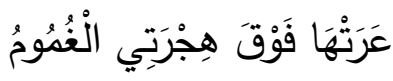

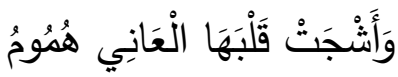

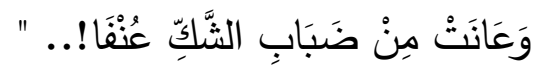
وفي مقطوعة قنصل هذه يتضـح الجناس بين قوله "غُمُومُ" وقولـه "هُمُومُ"، وهذا الجناس قد أحدث موسيقى هادئة تتناسب وحالة الحزن والألم التي قد تكون عليها أمه لو علمت بعداوة أحد له. كما يلاحظ التتاسب بين الكلمتين السابقتين؛ فكلُ منهما تجلب لصـاحبها الحزن والمرض، وتجعل حياته غير مستقرة ومضطربة. وقد خيمت موسيقى رقيقة هادئة على المقطوعة لما فيها من السجع؛ إذ

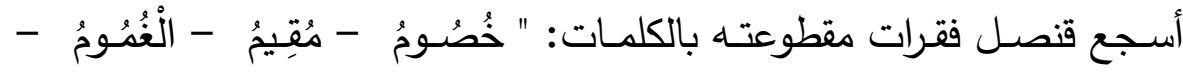
هُمُومُ "، وهذه الموسيقى المنبعثة من السجع تمنح الثعور بالثجن والحزن، فهذه الموسيقى تجعلنا وكأننا نشارك هذه الأم قلقها وحزنها. 
أثر التصوير البياني والتحسين البديعي هِّ أداء معنى الصفح فِ الشعر المهجري: القروي

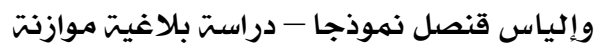

حوليت كليت اللغت العربيت بإيتاى البارود (العدد الثالث والثلاثون)

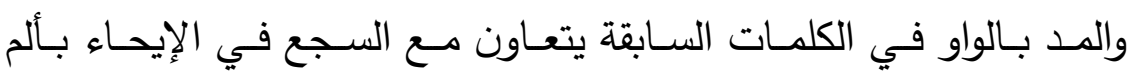
الثاعر ، ويساعد في تصوير أناته المتصـاعدة وزفراته المتلاحقة، وأنـه يتحمل

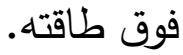
ويقول القروي في مقطوعته السابعة عشر : " عدوي أَنت عوسجةُ الحديقَهْ وأَنتََ الثوكُ في وردِ الحقيقَهْ

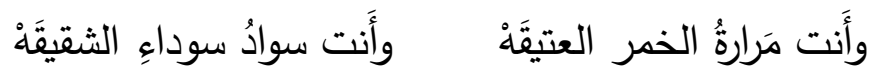

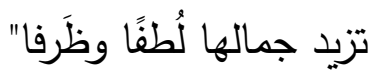

في هـه المقطوعـة يتضــح الجنـاس الاحسق بـين قولـه: "الحديقَّهُ" وقولـه: "الحقيقَهْ"، وجناس الاشتقاق بين قوله سوادُ " وقوله: "سودايَ "، ويتعانق مـع

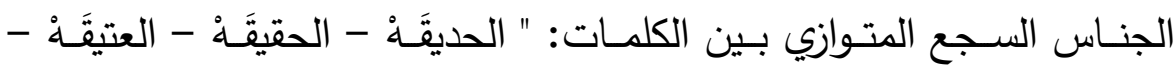
الثقيقَهُ " والتعاون الذي حدث بين السجع والجناس قد أضفى على المقطوعة نغدًا موسيقًا حادًا شديدًا، وهو ينقل لنا بدقة إلى أي مدى كان قلب القروي يمتلى ضيقًا وغيظًا من عدوه.

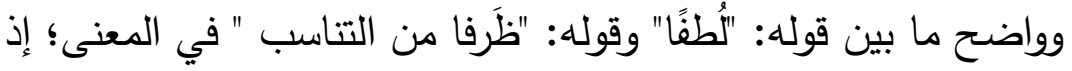

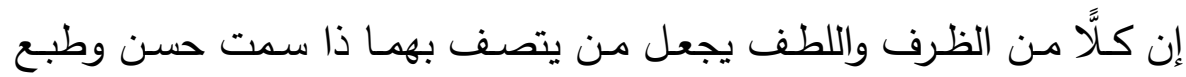
جذاب، وكل من يتعامل معاه يحبه ويقدّره.

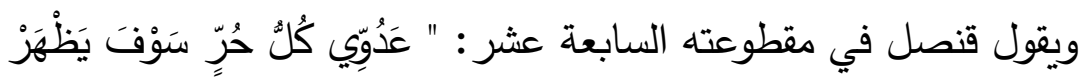

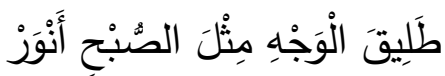

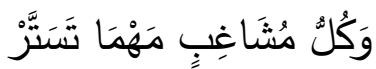

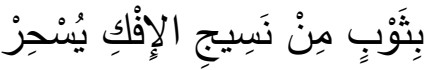

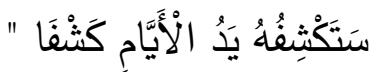

وفي مقطوعة قنصل هذه يلاحظ الطباق بين قوله "يَظْهَزْ " وقوله "تََتَنَّه"، والطبـاق يبـرز المعنـى ويوضـــه، وهـو أن حالــة الحُر تُبـاين تمامًا حالــة 
أثر التصوير البياني والتحسين البديعي فِ أداء معنى الصفح هٍُ الشعر المهجري: القروي

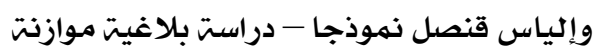

حوليت كليت اللغت العربيت بإيتاى البارود (العدد الثالث والثلاثون)

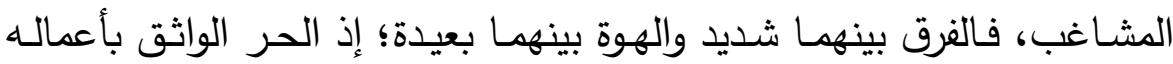

الطيبة يظهر ولا يتخفى، أما المشاغب فيخجل من تصرفاته فيتخفي ويتستر . ويلاحظ الترصيع في المقطوعـة وذلك مـن خـلال الجمـع بـين الكلمـات:

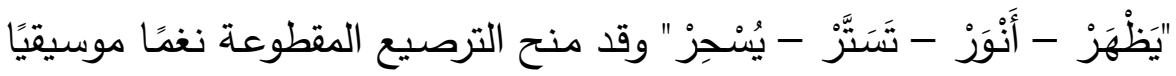
أطرب الأذن وهز الوجدان.

ويقـول القروي في مقطوعتهـ الثامنـة عشـر : "عدوّي ليت عينَك في فؤادي لتُصلحَ فيها مستترَ الفسادِ

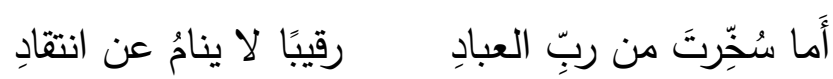

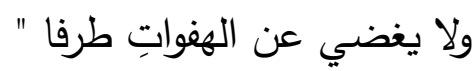

وقد طابق القروي في مقطوعته هذه بين قوله: "تصلح" وقوله: "الفساد"؛إذ طابق بين فعل واسم، وهذا الطباق قد أبرز التتاقض الثديد بين شخصية القروي وشخصية عدوه، إذ إنه دائمًا وأبدًا يريد الإصلاح، وعدوه يريد الفساد، ليزان فهما متناقدان لا يلتقيان أبدًا. وواضــح الموسيقى التي أحدثها الســع في المقطوعـة، حيث أسـجع القروي مقطوعته بالكلمـات: " فؤادي - الفسـادِ - العبـادِ - انتقـادِ"، واشـتمال الكلمـات

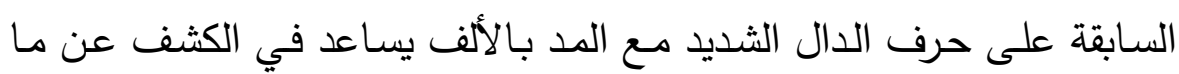
يحمله القروي من استياء شديد لعدوه وما يشعر به من ضنغط نفسي وضيق بسبب ترقبه له في كل خطوة وانتقاده الدائم دون مبرر •

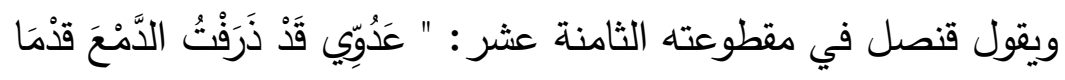

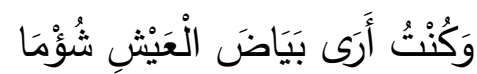

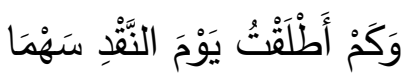

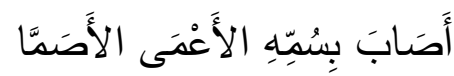

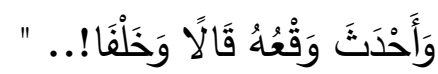


أثر التصوير البياني والتحسين البديعي فِ أداء معنى الصفح هٍُ الشعر المهجري: القروي

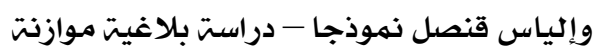

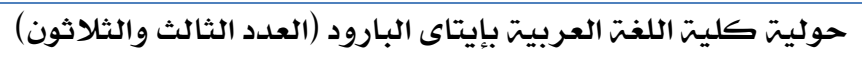

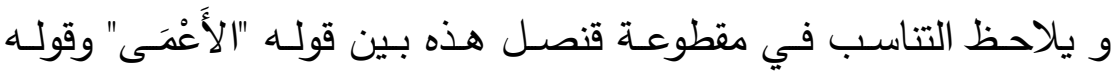

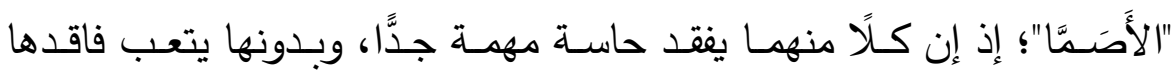
وتواجهه صـعاب كثيرة، ومـع هذا فقد أصـابتهما سـهام نقد الثـاعر، فلم يرفق

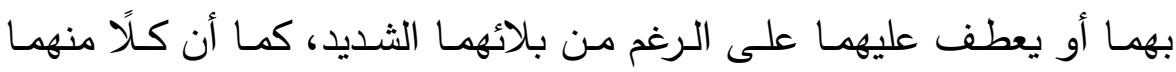
إعاقة تجعل صاحبها قوي الإرادة كثير التحدي، وهذا التناسب كثف عن مقدرة قنصل الفائقة في الجمع بين المعاني المتناسبة ووضْعها في مكانها الصحيح، مما يشهد بدقة تعبيره.

وفي المقطوعة يتضَح السجع بين قوله: " قذْمَا - شُؤْمَا- سَهْهمَا- الأَصَمَّا " وقد نشء عن هذا السجع موسيقى تتناسب والحالة النفسية التي كان يعيشها قنصل من الاعتراف بالذنب والندم عليه. وتأتي مقطوعة القروي التاسعة عشر ؛ إذ يقول فيها: " عَدُوبي دُمْ دوامَ الدهرِ

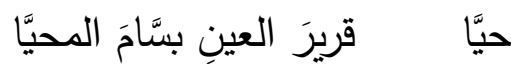

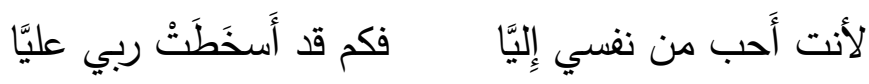
وكم نبّهتها حتى تكُفّا

ويتضح في مقطوعة القروي هذه جناس الاشتقاق بين قوله: " دُم "وقوله:" دوامَ "، فالأولى بمعنى ابقى والثانية بمعنى أبد، وكذا الجناس الناقص بين

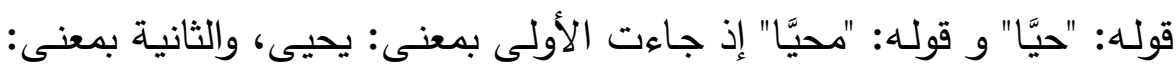

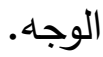

وكذلك يتضـح السجع بين الكلمات: حيَّا - محيَّا - إِليَّا - عليَّا" وهذا السجع وذلك الجناس قد أحدثا في المقطوعة موسيقى عذبة رقيقة تتناسب والجو الذي فرضتْه حالة الثاعر النفسية من السراع الذي كان يعيشه الثاعر بين المحبة والتقدير لعدوه وضيقه الثديد منه بسبب فعله تجاهه.

كما يلاحظ الطباق بين قول القروي "عدوي" وقوله "أحب"، فهذا الطباق قد أكد ما عليه الشاعر من صراع نفسي بين شعوره تجاه عدوه بالعداء وشعوره 
أثر التصوير البياني والتحسين البديعي فِ أداء معنى الصفح فِّ الشعر المهجري: القروي

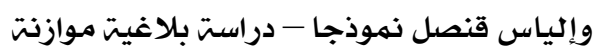

حوليت كليت اللغت العربيت بإيتاى البارود (العدد الثالث والثثلاثون)

بمحبته له، والقروي يتمزق بين هذين الثعورين، فكل منهما يجذبه ويشدُّه إليه

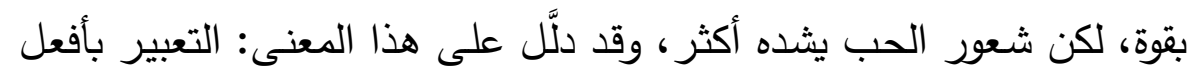

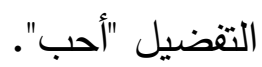
ويقول قنصل في مقطوعته التاسعة عشر : " عَدُوِي كُنْتُ مَغْرُورًا بنَفِِْي

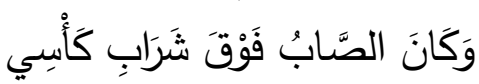

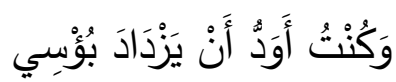

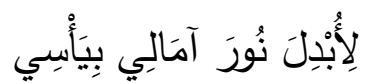

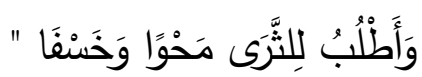

وفي مقطوعة قنصل هذه يتضح الجناس اللاحق بين قوله "كَأْسِي" وقوله

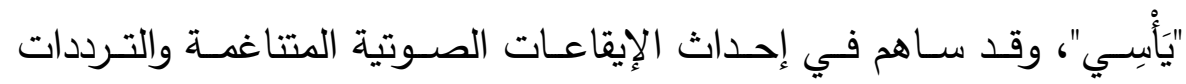
المتوافقة في المقطوعة: تسجيع فقراتها بالكلمات: " نَفْبِي - كَأْسِي - بُؤَسِي بِيَأْسِي " مما أضفى على المقطوعة موسيقى عذبة مؤثرة تتناسب والجو النفسي

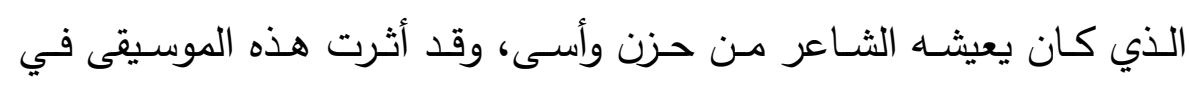

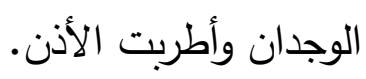

ويلاحظ أن ( التلاؤم في صيغة التعبير وتزاحم المعـاني في البيت والجرس الذى ينبعث عنه الترديد(')، والضغط الذى ينصب على على النفس من كل جانب،

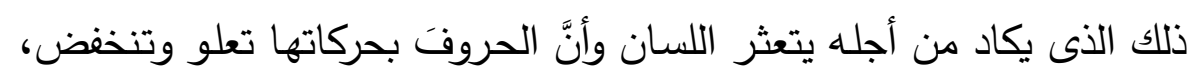
ويمتد اللسان ويتقلص تبعًا لعلوها وانخفاضها تحدث ايقاعًا لو اقتصرنا عليه

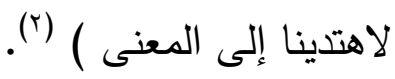

(1) الترديد: هو أن يعلق المتكلم لفظة من الكلام بمعنى ثم يردها بعينها ويعلقها بمعنى آخر.

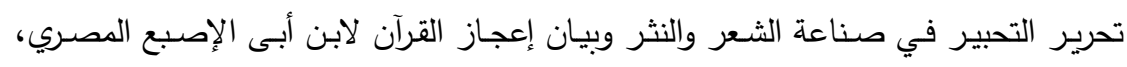

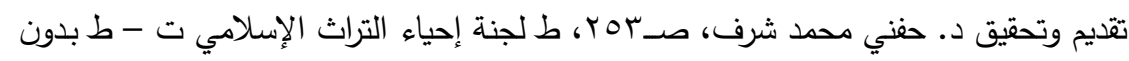
تاريخ.

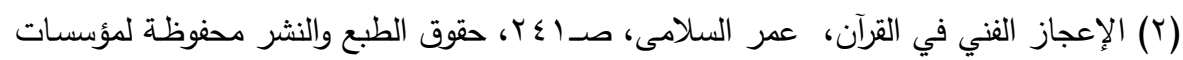

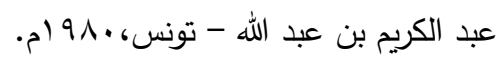


أثر التصوير البياني والتحسين البديعي هِّ أداء معنى الصفح فِ الشعر المهجري: القروي

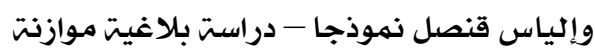

حوليت كليت اللغت العربيت بإيتاى البارود (العدد الثالث والثلاثون)

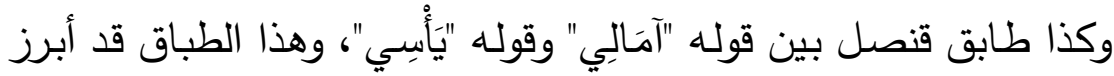

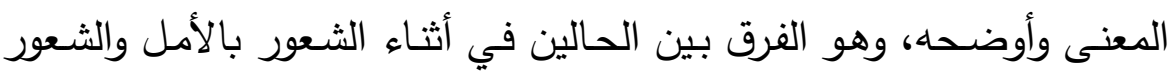

باليأس، فالأمل يبعث في النفس التفاؤل والإقبال على الحياة، أما اليأس فيبعث في النفس التشاؤم والإحجام عنها والبعد عن الناس.

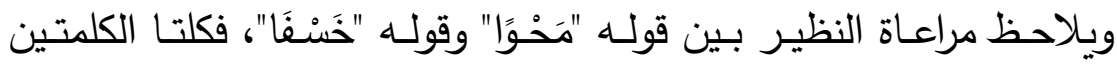
تعطي معنى التلاشي والانتهاء، وقد أدى هذا اللون البديعي إلى التركيز في المعنى المراد وتأكيده.

وتأتي المقطوعة العشرين للقروي حيث يقول فيها: " عدوُّك يا عدوي من

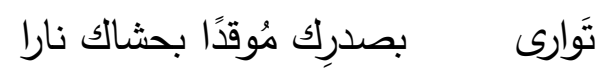

فإن تطلُبْ من الأعدايٍ ثارا فآخ الناس وانتحرِ انتحارا فأَعداهم بثُبك قد تخفّى "

وفي المقطوعة هذه يلاحظ الجناس اللاحق بين قولهه "نارا" وقولـه "ثارا"، وفي الوقت نفسـ يجمع بينهما السجع المتوازي، وكذا السجع المطرف بين

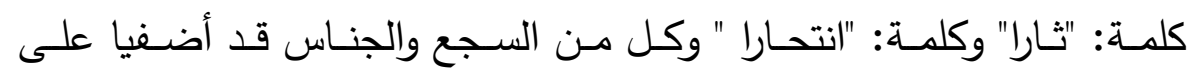
المقطوعة موسيقى عالية جلبة تتاسب الحدة التي يتحدث بها القروي مع عدوه، وتسـاعد في تصـوير مـا بـداخل الثـاعر مـن بركان غضـب وغيظ مـن ذلك العدو.

ويتضـح الطباق بين قوله:" عدوُّك " وقوله: " آخ "، والطباق يجعل القارئ والسـامع يعقد مقارنـة بين العـاوة والإخـاء، فيصـل بنفسـه إلى الفـرق الثـديد بينهما، وهو أن العداوة تجعل صـاحبها في قلق دائم وتوتر مستمر؛ إذ يمتلىئ قلبه دائمًا لعدوه بالغل والحقد، أما الأخوّة فتجعل صـاحبها في هدوء وسكينة دائمة، فقلبه ممتلئ دومًا بكل المشاعر الطيبة لأخيه، فشتان ما بينهما. ويقول قنصل في مقطوعته العشرين: " وَلَكَنِّي جَنَحْتُ إِلَى الصََّوَابٍ

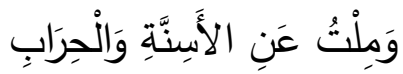


أثر التصوير البياني والتحسين البديعي هِّ أداء معنى الصفح هٍِ الشعر المهجري: القروي

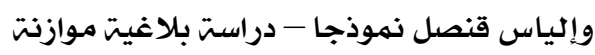

حوليت كليت اللغت العربيت بإيتاى البارود (العدد الثالث والثلاثون)

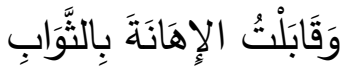

فَخَفَّتُ شِقْوَتِي.... وَنَأَى عَذَابِيَ

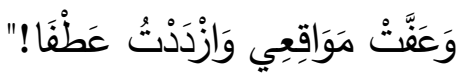

وفي المقطوعة هذه يتضـح الترصيع بالكلمات التالية: " الصَّوَابٍ - الْحِرَابِ -

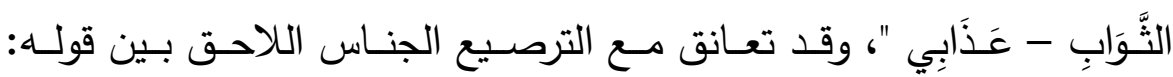

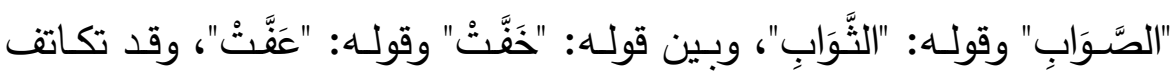
الترصيع مع الجناس في إحداث موسيقى رقيقة هادئة تتتاسب والهدوء والراحة النفسية التي أصبح عليها الثاعر ، كما ساعدت الموسيقى في الكثف عن التناغم النفسي بين أفكار قنصل التي أصبحت عاقلة ومتوازنة. كما يلاحَظ في المقطوعة نفسها فن مراعاة النظير بين قوله "الأَسِنَّةِ" وقوله لهـ "الْحِرَابِ"، وهذا الفن يشعر بالتتاسب والتاؤم بين اللفظين، فكل منهما وسيلة

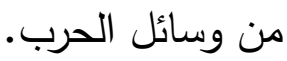

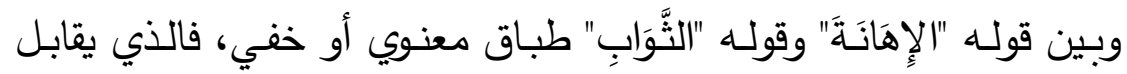

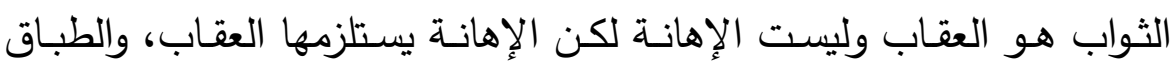
يسـاعد في تصـوير حـالي كلِّ مـن المعاقب والمثاب، فـالفرق بـين الحـالين واضـح؛ إذ المعاقب يشعر بالذل والهوان، والمثاب يشعر بالعزة والإكرام، فما

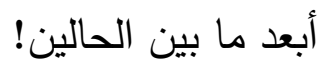
وتأتي المقطوعة الحادية والعشرين للقروي إذ يقول فيها: " عدوِي أَنت في حُلمٍ مخيفِ يروءك بالبنادق والسيوفِ

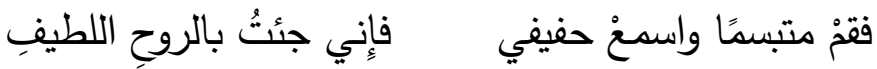

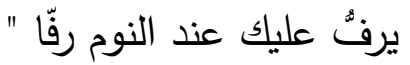

والقروي في مقطوعته هذه يعتمد على الجرس الصوتي في تحسين معناه وتزينــه؛ إذ رصـع المقطوعـة بالكلمات التالية: "مخيفِ - السيوفِ- حفيفياللطيفِ"، وقد أحدث هذا الترصيع موسيقى عذبة رقيقة تطرب الأذن، وتؤثر 
أثر التصوير البياني والتحسين البديعي فِ أداء معنى الصفح هٍُ الشعر المهجري: القروي

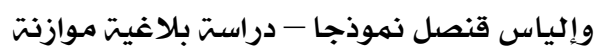

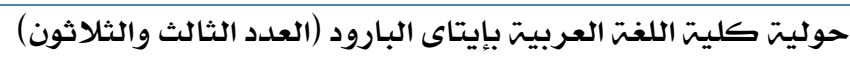

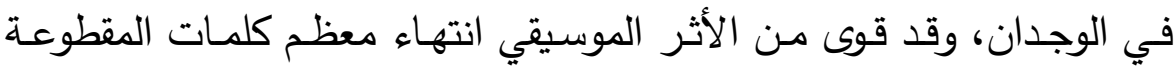
بحرف الفاء المهموس الذي يتعاون بدوره مع الترصيع في رسم جو من الهدوء والطمأنينة والسكينة والذي يتمنى القروي أن يعيشه عدوه.

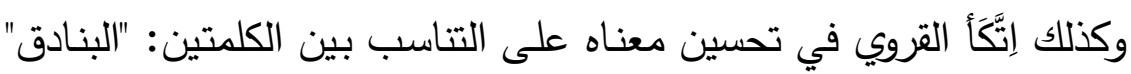
و"السيوفِ" إذ إن كلًَّ منهما أداة من أدوات القتال ووسيلة من وسيائل الدفاع عن النفس أو الهجوم، والتعبير بهاتين الكلمتين يثير في النفس الذعر والرعب إنب دون ويرسم الهلاك والفناء ويشعر بجو الحرب. ويقول قنصل في مقطوعته الحادية والعشرين: " عَدُوِي كُلُّ سَطْرِ مِنْ سُطُورِي

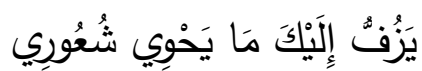

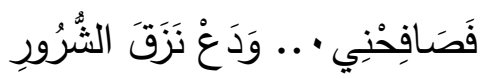

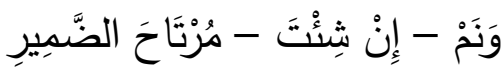

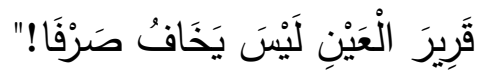
وفي المقطوعة هذه لقنصل يلاحظ الجناس اللاحق بين قوله "شُعُور" وقوله "شُرُور"، وكذلك نـلاحظ أنه قد رصع مقطوعته بالكلمات: " سُطُورِي - شُعُورِي

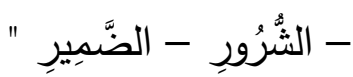
وهذا الترصيع وذاك الجناس قد بعثا في المقطوعة موسيقى رقيقة هادئة أثرت في الحس والوجدان، وساعدت في التعبير عن حالة يعيشها قنصل من الاتزان العقلي والهدوء النفسي وهو يخبر عدوه بأنه برغم كل شيء فعله معه إلا أنه يحبه ويقدره، مما يوحي بشدة تسامحه وصفحه.

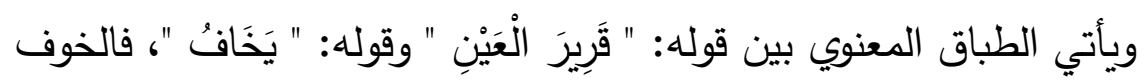

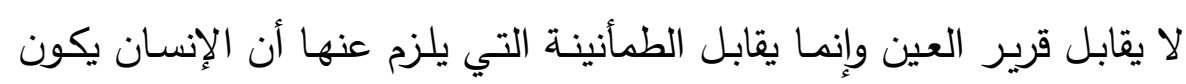

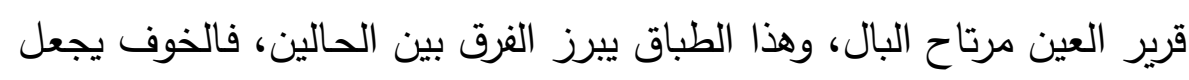

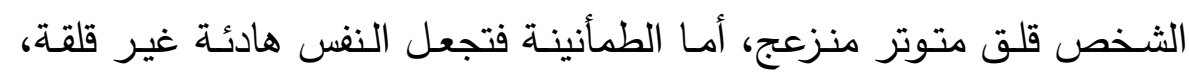
وإنما تشعر بالأمان. 
أثر التصوير البياني والتحسين البديعي هِّ أداء معنى الصفح فِ الشعر المهجري: القروي

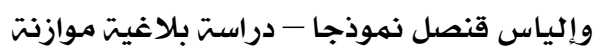

حوليت كليت اللغت العربيت بإيتاى البارود (العدد الثالث والثثلاثون)

ويقول القروي في مقطوعته الثانية والعشرين: " عدوّي بحرُ حبيَ قد ترامى بيتي فخُضْ أَو غُصْ ولا تخش ارتطاما

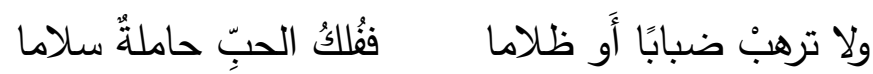
تحفُّ بها جواري الأمنِ حفّا

وفـي المقطوعـة هـذه قـد اسـتعان القـروي في تحسـين معنـاه بالسـجع المتوازي بين الكلمـات: " ترامسى - ارتطامـا- ضـبابًا - ظلامـا- سـلاما "، وقد منح الترصيع المقطوعة موسيقى عذبة رقيقة تساعد في التعبير عن مشاعر الدفء والطمأنينة والاحتواء.

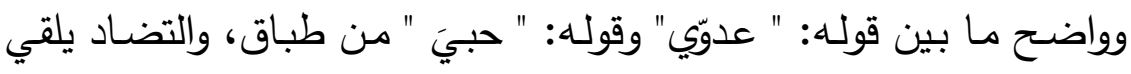
بظلاله على المفارقة الثديدة بين العداوة والمحبة، فالفرق بينهما واضح وضوح

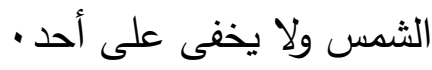
ويلاحَظ التتاسـب بين "ضـبابًا" و "ظلامًَا"، فكلٌٌ منهمـا يترتب عليـه انعدام

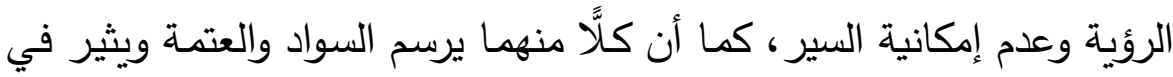
النفس الوحشَة، واستخدام القروي هاتين اللفظتين لم يكن منـه جزافًا؛ بـل إنـه يقصدهما قصدًا، فكلمـة " ضـبابًا " ترمز لمـا يتسـم بـه عدو القروي من عدم وضوح ومصداقية في التعامل معه، وتشف عن عدم نقائه، وأما كلمة " ظلاما " فترمز لما يملأ قلب عدو الثاعر من سواد يظهر على هيئة حقد وغل وحسد للثاعر ولكل شخص ناجح، مما يوحي بقبح هذا العدو وخبثه. ويقول قنصل في مقطوعته الثانية والعشرين: " عَدُوِي لَا تَخَفْ مِنِيِي... فَمَا

$$
\begin{aligned}
& \text { فِي ضُلُوعِي مِنْلَكَ دَاعِ للِلتَّجافِي }
\end{aligned}
$$

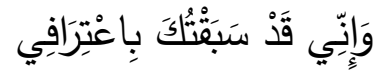

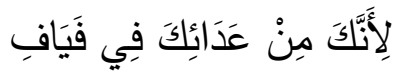

" بِهَا غُصْنُ الْوَفَا وَالْحَبِّ جَفَّا 
أثر التصوير البياني والتحسين البديعي هِّ أداء معنى الصفح فِ الشعر المهجري: القروي

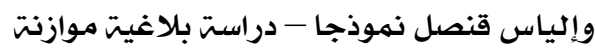

حوليت كليت اللغت العربيت بإيتاى البارود (العدد الثالث والثثلاثون)

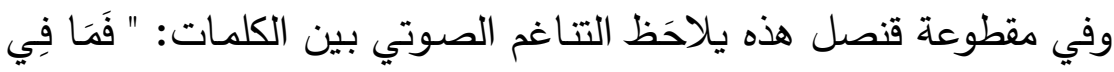

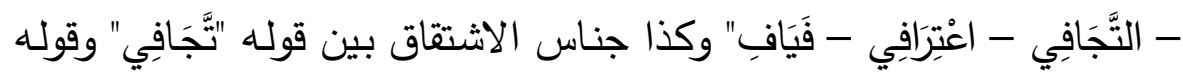
"جَفَّا"، وقد أحدث هذا الجناس وذاك التناغم الصوتي تتاسقًا موسيقيًا، والذي بدوره منح المقطوعة نبضًا وحياة، فقد انبعثتْ منها موسيقى عذبة هادئة رقيقة

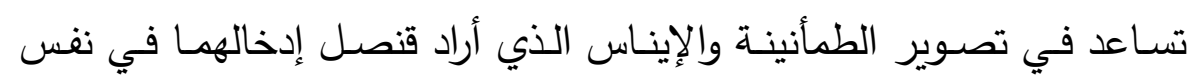
عدوه.

وقد كان التضـاد من الوسائل التأثيريـة التي استعان بها قنصل في تحسين

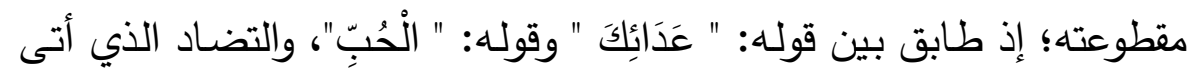
به قنصل لم يكن مجرد محسن معنوي، وإنما جاء به لينقل لنا بدقة ما بداخله من صراع نفسي يمزقه، فالثـاعر تتجاذبه المشاعر المتضـادة نحو عدوه،فهو مشتت بين حبه لله بسبب صفحه وتسامحه الثديد وبين عداوته لله بسبب ما لهر لاقاه منـه من حقد وغل وحسد، فقلٌ من الشعورين يشده نحوه بقوة، ولا يدري ماذا يفعل. ويقول القروي في مقطوعته الثالثة والعشرين: "عدوي سوف تطحنُنا القبور وتنخلُنا وتجبلُنا الدهور

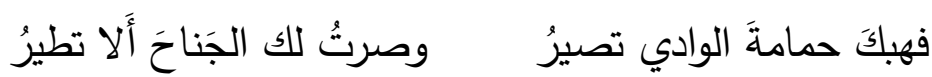
أَو العُش الطريّ ألست تدفا؟!"

وفي مقطوعـة القروي هذه يـاحَظ التناسـب بـين قولـه "تطحنُــا" وقولـهـ "تتخلنا"، فهما متلازمان ويترتب أحدهما على الآخر ، فبعد الطحن يأتي النخل، فالتعبير بالنخل بعد الطحن يشعر بالفناء التام المؤذن بالتلاشي والعدم.

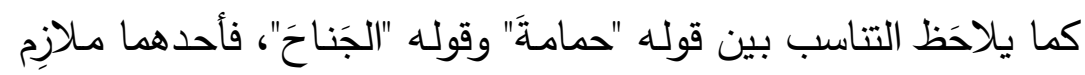

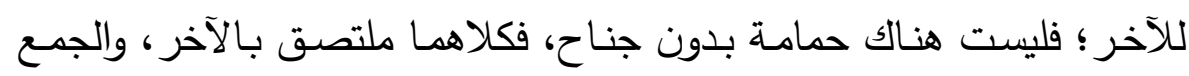
بين هذين اللفظين يساعد في الإشعار بالمعنى المقصود، وهو (التحليق في عالم الحب والسلام)، وأنه لا توجد محبة بدون سلام ولا سلام بدون محبة. 
أثر التصوير البياني والتحسين البديعي هِّ أداء معنى الصفح بِّ الشعر المهجري: القروي

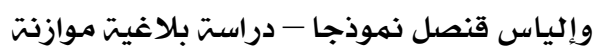

حوليت كليت اللغت العربيت بإيتاى البارود (العدد الثالث والثثلاثون)

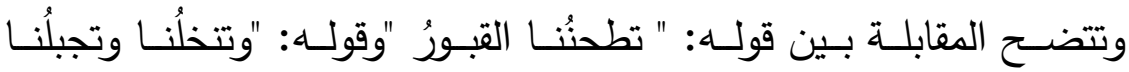
الدهور "، والمقابلـة في المقطوعـة قد أدت إلى الوفاء بالمعنى وتمام الغرض،

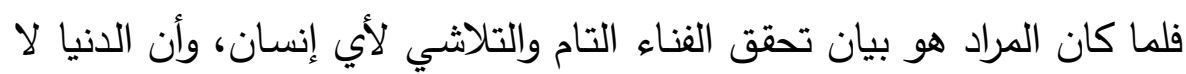
تبقى لأحد كانت المقابلة هي الأوفى بهذا الغرض وأتم له. ويـأتي الجنـاس اللاحق بين "تصير" و "تطير" ليتعـاون بدوره مـع سجع فقرات المقطوعـة بالكلمـات: " القبوز - الدهوز - تصير - تطيرُ "، وقد تكاتفا المحسنان اللفظيان (الجناس - السجع ) ليضفا موسيقى هادئة تُشِعر بالثجن، وتتناسب الموسيقى الناشئة عن الجناس والسجع مع الجو الروحي الذي يرجو الشـاعر من عدوه أن يستشعره ويتفاعل معـه، كما تآزرت هذه الموسيقى مـع كلمـات البيت في إيصـال الفكرة وإيضـاحها، وهي التحليق في عـالم الحب والسلام مع النفس والآخرين.

ويقول قنصل في مقطوعته الثالثة والعشرين: " عَدُوِي لَسْتُ أَخْدِمُ فِي يَرَاعِي

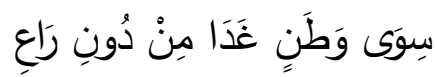

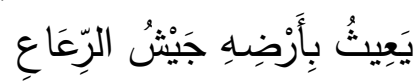

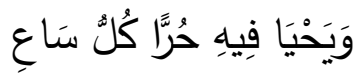

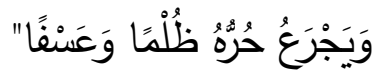

ويتضح في مقطوعة قنصل هذه الجناس الناقص بين قوله "يَرَاعِي" وقوله "رَاعِ"، والجناس اللاحق بين قوله: "رَاعِ" وقوله: "سَاعِ، كما يلاحظ السجع في المقطوعة بالكلمات: " يَرَاعِي - رَاع- الرِّعَاعِعَ - سَاع "، وقد نشأ عن التحسين اللفظي بالسجع والجناس موسيقى عالية صاخبة تتآزر مع التراكيب في إيصال المعنى وتأكيده، وهو شعور قنصل بالألم والحسرة على وطنه وما يجري فيه، وأنه يتنفس الصعداء ويحمل هموم ثقيلة كثيرة. 
أثر التصوير البياني والتحسين البديعي هِّ أداء معنى الصفح مِّ الشعر المهجري: القروي

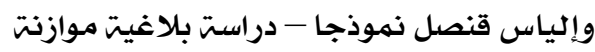

حوليت كليت اللغت العربيت بإيتاى البارود (العدد الثالث والثثلاثون)

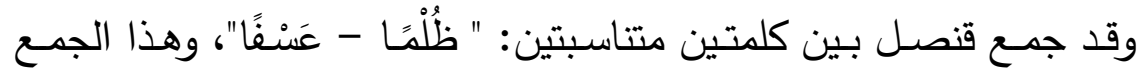
يوحي بمعاناة الشـاعر الثديدة من التعسف الذي يلاقيه في وطنه والثـعور القوي بالظلم والاضطهاد.

ويقول القروي في مقطوعته الرابعة والعشرين: " وهَبك السيلَ يجترفُ الصخورا وهبك الريخَ تقتلعُ الجذورا

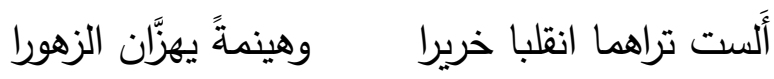
وسالا في الرياض ندى ولطفا؟

وقد لعبـت المقابلـة في مقطوعـة القروي هذه دورًا مهمًا في الكثـف عن لن المعنى وإيصاله إلى السامع والقارئ بأوجز طريق وأقصره.

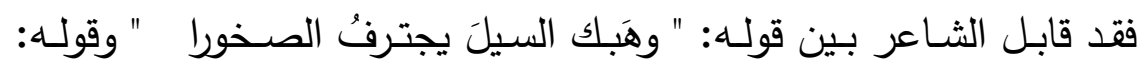
"وهبك الريخَ تقتلعُ الجذورا"

إذ قابل "السيلَ - يجترفُ - الصخورا" بـ"الريخح - تقتلعُ - الجذورا"، كما قابل بين البيت السابق والبيت التالي:

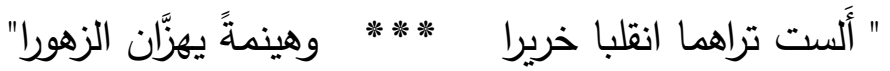
فقد قابل بين حالين للماء والريح، فجعلهما يجترفان الصخور ويقتلعان الجذور مرة، و مرة أخرى جعلهما خريرًا وهينمةً يهزَّان الزهور ، والمقابلة كانت فئران

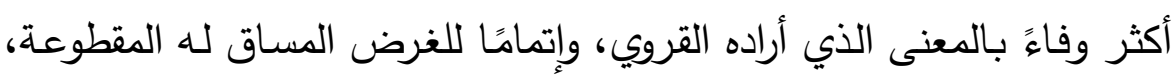
فقد كان الغرض إبراز قسوة عدوه وجمود قلبه وتحجر عقله، والكثف عن حقده

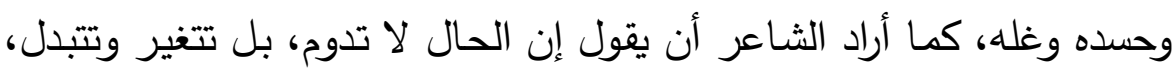

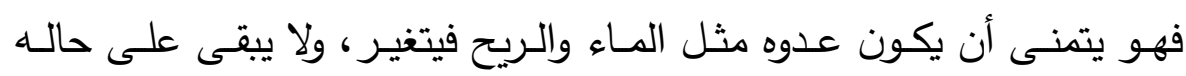
المؤذي لنفسه ولغيره، وقد أوفت المقابلة بهذا كله.

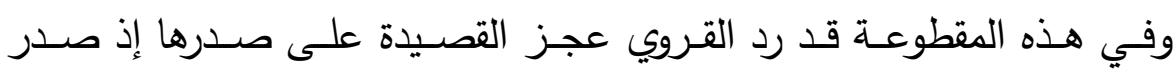
القصيدة بقوله: " سأجرُقُ بغضكم بالحبّ جرفا" ثم قال هنا: "السيلَ يجترفُ الصخورا "، وهذا الفن (رد العجز على الصدر ) قد جعل القارئ يساوي بين 
أثر التصوير البياني والتحسين البديعي فِ أداء معنى الصفح هٍُ الشعر المهجري: القروي

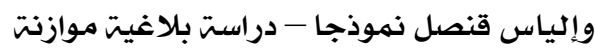

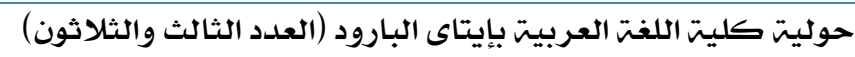

القروي والسيل في كلٍ من القوة والرقة، فقد كان القروي قوي الإرادة شديد العزم

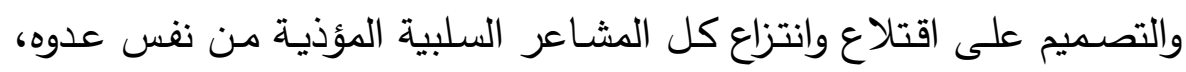
وفي الوقت نفسـه كان محبى ودودا لـه حريصـا على مصلحته ووضـعه، وقد جاء هذا الفن من القروي طبعيًا غير متكلف؛ لذا أضفي على القصيدة نغما موسيقيًا رائعًا أثشاع روح التحدي والهمة العالية في تحقيق الهدف. وقد تآزر مـع الفـن السـابق السـع في في المقطوعـة بالكلمـات: " الصــورا

$$
\text { - الجذورا - خريرا - الزهورا ". }
$$

والمد بالواو مـع انتهاء الكلمات بحرف الراء الذي يثيع رقة وانسيابية في

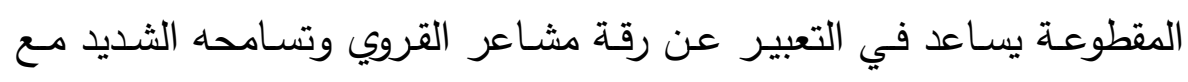
عدوه. وثمَّة تناسب بين "يجترفُ - تقتلعُ"، فكلٌٌ منهما يشعر بنزع الثيء من مكانه بقوة وعنف، وقد تآزر اللفظان في إبراز معنى القوة والعنف.

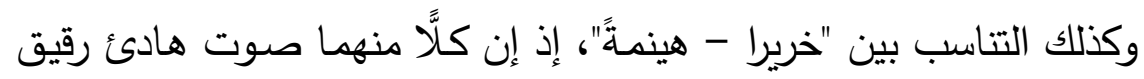
ترتاح إليه الآذان وتستمتع به النفوس.

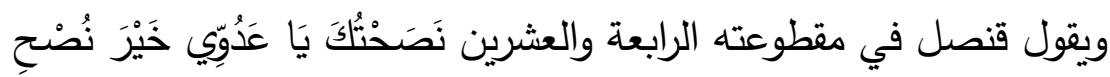

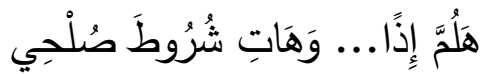

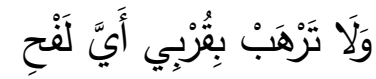

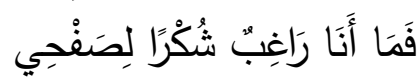

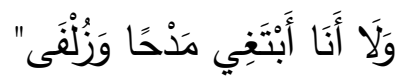

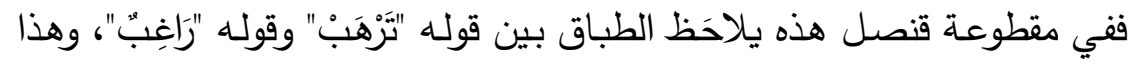

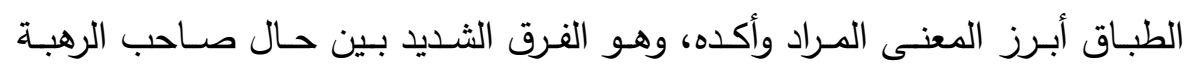

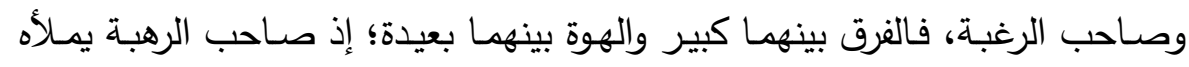
الخوف والفزع ويحيط به القلق، أما صاحب الرغبة فيملأه الأمل في القادم والتفاؤل 
أثر التصوير البياني والتحسين البديعي فِّ أداء معنى الصفح مِّ الشعر المهجري: القروي

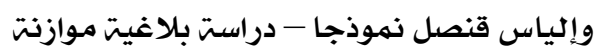

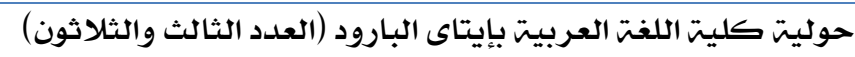

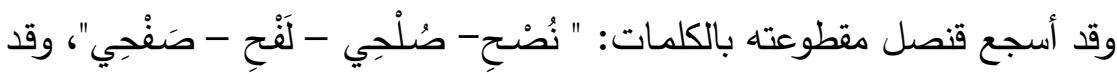

تكاتف مع السجع الجناس بين قوله "لَفْحِ - صَفْحِي"، وهذا التكاتف الصوتي قد منح

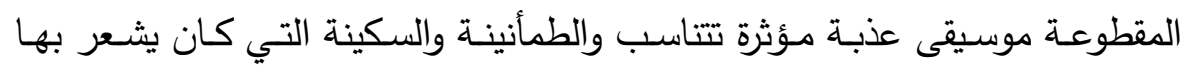
قنصل في أثناء نظمها هذه المقطوعة. ويقـول القـروي فـي مقطوعتـهـ الأخيـرة: " عـدوّي قِـف قلـيلاً فـي المســاءٍ وطالِع بعضَ آيات السماءِ

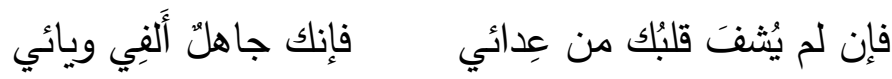
ومن "تسبيحتي" لم تتلُ حرفا"

وفي المقطوعـة الأخيرة للقروي يتضـح جنـاس القلب بين قولـه: "مسـاء" وقولـهـ "سماء"، وكذا الترصيع بالكلمات: المساءِ - السماءِ - عِدائي - يائي"، وقد منح التناغم الصوتي الناشئ عن الجناس والسجع المقطوعة موسيقى ناعمة رقيقة هادئة، تتناسب والموقف التأملي والنظر في السماء في وقت المساء. ويتآزر المد بالألف مـع الحرف الثديد الهمزة في الكلمات السابقة ولئل لإحداث هذه الموسيقى العذبة الرقيقة، وللإيحاء برغبة الثـاعر القويـة في إدامة نظر عدوه مدة طويلة في آيات السماء، عله يهتدي ويتغير.

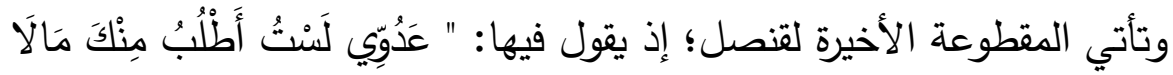

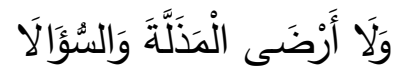

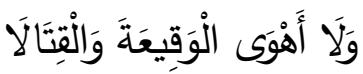

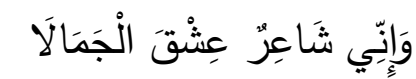

وفي المقطوعة الأخيرة لقتصل يلاحَظ التتاسق الصوتي والنغمي، وقد نثأ هذا

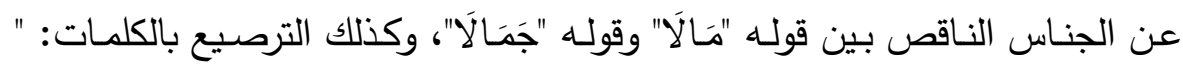

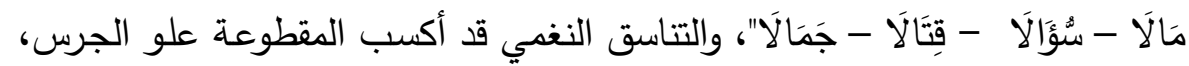
وطلاوة نغم يتناسبان ومقام الفخر والاعتزاز بالنفس والزهو بعشق الجمال.

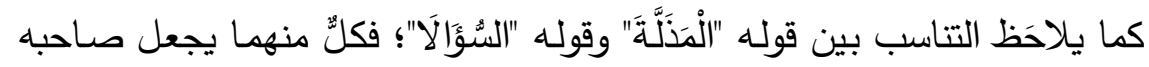
مَخْزِيًا ذليلًا لا يستطيع أن يرفع رأسه. 
أثر التصوير البياني والتحسين البديعي ِِّ أداء معنى الصفح ِِ الشعر المهجري: القروي

وإلياس قنصل نموذجا - دراست بلاغيت موازنت

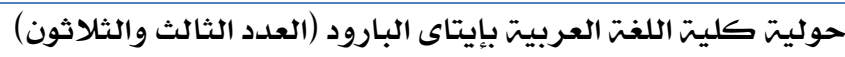

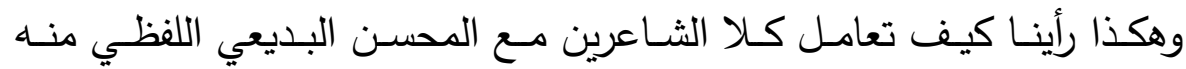

والمعنوي في القصيدتين، وكيف وظفاه التوظيف الصـيح الذي خدم المعنى

وأيد الفكرة. 
أثر التصوير البياني والتحسين البديعي ِِّْ أداء معنى الصفح ِِّ الشعر المهجري: القروي

وإلياس قنصل نموذجا - دراست بلاغيت موازنت

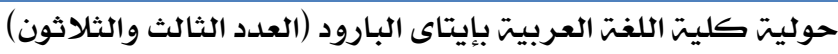

\section{المبحث الثالث}

\section{سمات التصوير البياني والتصسين البديهي \\ في أداء همنى الصفح بين: القروي وقنصل:}

أولًا: سمات التصوير البياني:

من خلال دراسة الصورة البيانية في القصيدتين يلاحظ أنها قد انبتقت

لدى الثـاعرين مـن عدة مصـادر ، أهمها الثقافـة الدينيـة، والتـاريخ، ومشـاهد

الطبيعة.

وقد امتازت الصسور الفنية في قصيدة القروي بكثير من المزايا التي

يمكن أن تمثل سماتٍ عامة لها؛ كالمبالغة في التصوير ، والتنوع في الأساليب،

$$
\text { وتعددها حتى في المقطوعة الواحدة. }
$$

ولم يقف إبداع الثاعرين في هذه القصيدة عند حدود التصوير الجزئي؛

بل كان للصورة الكلية حضور متميز في القصيدتين، فقد رسَما لنا لوحـات

تآزرت فيها الصور الجزئية، وتعانقت المشاهد الفردية.

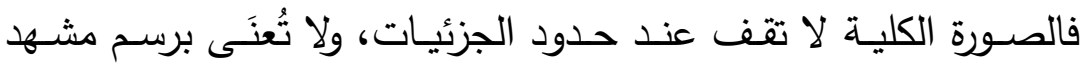

منفرد، إنما تتكون من "مجموعة من الصور الجزئية التي سرعان ما تتضـام

وتتـاخل وتتناغم، لتسهرم في إنتاج لوحـة فنيـة كبيرة زاهيـة بأصباغها، ميَّاسـة

بحركتها، ناطقة بالأصوات والأصداء، بمعنى أنه يجب أن يتوافر للوحة الفنية

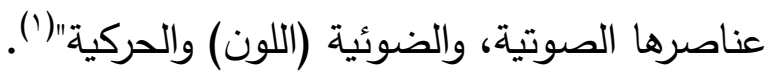

ومن تلك اللوحات الفنية في قصيدة القروي مقطوعته الثانية التي يبدأها

بقوله:" بَني أُمي الجياع إلى خِصسامي ألا ذقتم يسيرًا من طعامي.."إلخخ، فقد ضمت هذه المقطوعة لوحة فنية رائعة مكونة من الصورة الاستعارية والصورة

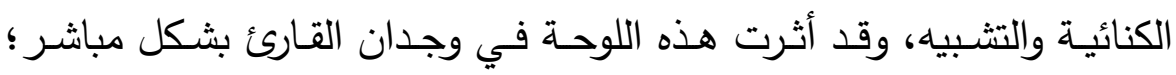

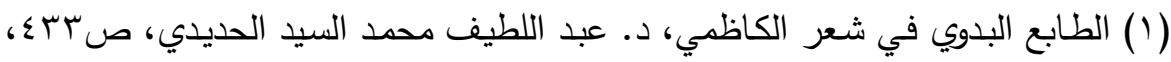

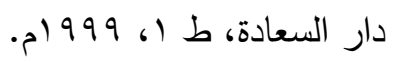


أثر التصوير البياني والتحسين البديعي فِ أداء معنى الصفح هٍُ الشعر المهجري: القروي

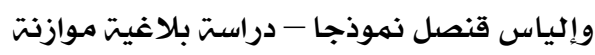

حوليت كليت اللغت العربيت بإيتاى البارود (العدد الثالث والثلاثون)

لاشتمالها على العناصر اللازمة من الإيحاء والخيال والتصوير .

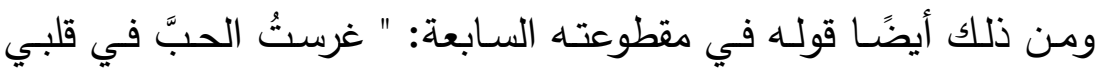

صغيرا..." إلخخ، فهذه اللوحة الفنية قد ضمت ثلاث صور استعارية، وتشبيه،

وقد تآزرت هذه الصور وتكاتقت في إبراز المعنى المراد بشكل موحِ ومؤثر . ومنها قوله في مقطوعته الحادية عشرة: " رأيتُ الوحش يأنس للأغاني..." إلخخ، إن هذه اللوحة مليئة بالصور الرائعة المتتوعة، فقد ضمت ثـلاث صور بيانية: ( الاستعارة - والكناية - والمجاز المرسل )، وقد اعتمدت في الاستعارة على التشخيص والتجسيد، وأبرزت هذه الصور المعنى للقارئ وأوضحته كأنه يشاهد المشهر بنفسه. ومنها مقطوعته الرابعة عشرة إذ يقول فيها:" لما طرحَت بنا أَيدي الخطوب

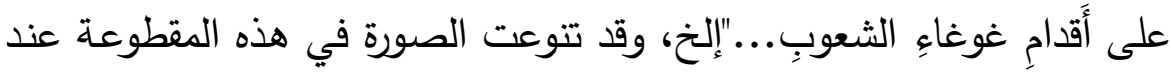
القروي بين التشبيه والاستعارة، مما جعل اللوحة ذات خطوط واضحة وألوان زاهية، تمتع القارئ وتوضـح لله المعنى المراد.

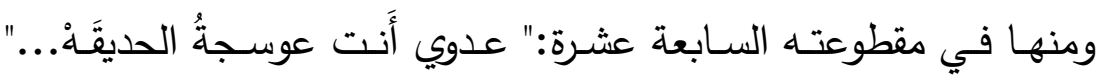
إلخ،لقد بـدأ الثـاعر هذه اللوحـة بتشبيهين، وجـاء في أوسطها باستعارة، ثم

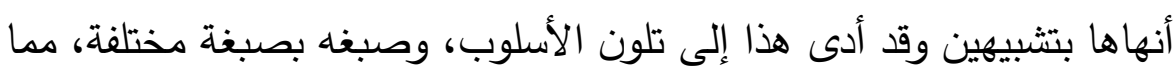
جعله أكثر تأثيرًا في النفس وأقرب للوجدان.

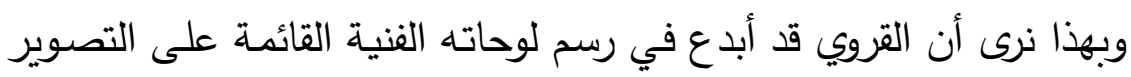
الكلية وضم جزئيات التصوير في لوحة فنية متصلة الخطوط متكاملة الأركان. وقد كان لقنصل بعض اللوحات الفنية التي تمثل صورًا كلية في قصيدته، وإن كانت قليلة، إلا أنها تكثف عن مقدرته الفائقة وإحساسه العلي الفني، ومن

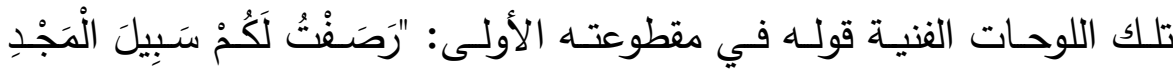
رَصْفَا..."، إلخ، فقد تكونت الصورة الكلية من الاستعارة المكنية والتشبيه، وقد جعل هذان الفنان اللوحةَ تنطق بكل روعة وجمال. 
أثر التصوير البياني والتحسين البديعي فِ أداء معنى الصفح هٍُ الشعر المهجري: القروي

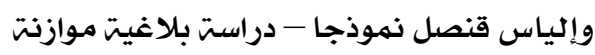

حوليت كليت اللغت العربيت بإيتاى البارود (العدد الثالث والثلاثون)

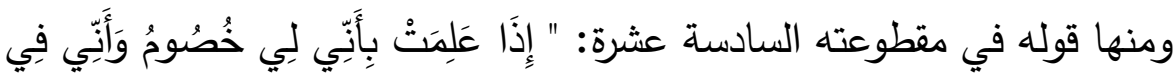

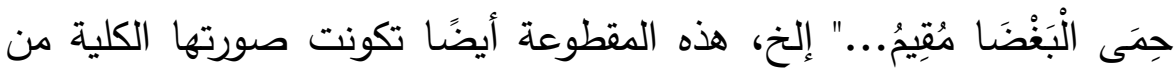
فنَّي الاستعارة والتثبيه، مما جعل اللوحة أكثر وضوحًا في تقاسيمها وألوانها.

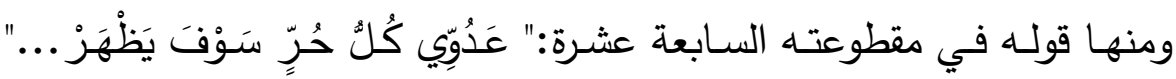
إلخهوقد كان أبرز خطوط اللوحة في هذه المقطوعة الاستعارة، التي أفصحت

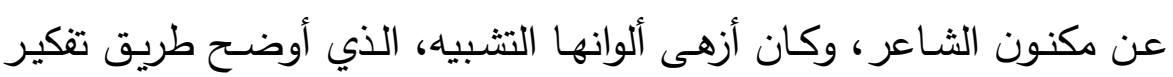
الشاعر ورؤيته للحياة.

ومنها قوله في مقطوعته الثانية والعشرين:" عَدُوِي لَا تَخَفْ مِنِي فَفَا فِي

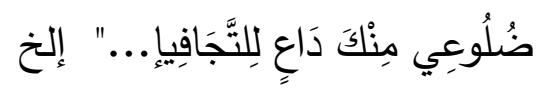
إن اللوحة الفنية في هذه المقطوعة قد اشتملت على عدد من الصور الجزئية والتي بدورها قد كونت صورة كلية كالمجاز المرسل والاستعارة والتشبيه، وفن المجاز المرسل قد بث في لوحة قنصل روحًا وجعلها تنبض بالحياة، فهو مع الاستعارة والتشبيه قد جعل خطوط الصورة الكلية أزهى وأكثر وضوحًا. ويعتبر المجاز المرسل من ألوان التصوير التي قل استعمالها من الثاعرين في قصيدتيهما، فقد رأى كلاهما أن الصور البيانية الأخرى أكثر تعبيرًا وأدق تصويرًا.

وهكذا نـرى أن للصـورة الكليـة بـين الدراسـة الفنيـة أهميـة كبـرى، ومكانــة

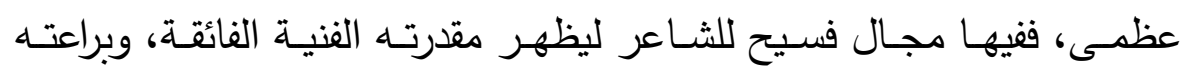
التصسيرية الرائقة، ويبرز تمكنه من السيطرة على أدواته الشعرية من جـلاء معنى، وجمال لفظ، وسلاسة أسلوب، ونغمة موسيقي.

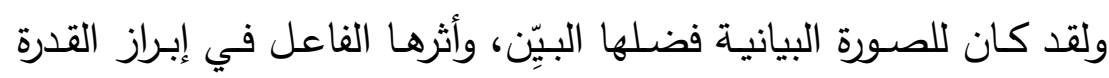
الفنية، والطاقة التصويرية لشـاعرنا القروي؛ فلم يقف بلغته الثعرية عند حد ولـ المعنى المجرد والتعبير الجاف، بـل نجده قد فجر من اللغـة طاقتها الكامنـة 
أثر التصوير البياني والتحسين البديعي فِّ أداء معنى الصفح بِّ الشعر المهجري: القروي

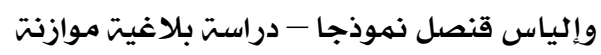

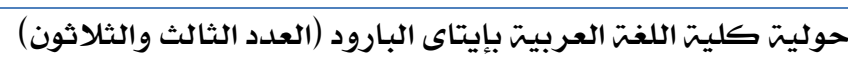

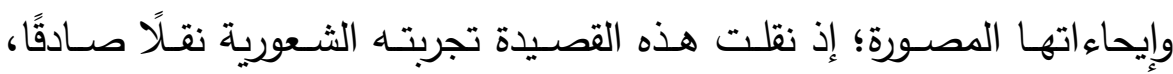
وتطابقت انفعالاته العاطفية - حزنًا وفرحًا، هدوءً وصخبًا - تطابقًا تكاد تكون تامة أو متقاربة، مما أنبأ عن ملكة فنية خلاقة، وموهبة شعرية رائعة. كذا الثاعر قنصل قد كانت له لوحات فنية رائعة، إلا أنه كان مُقلًَّا منها، وكانت الصورة الكلية لديه محدودة بألوان محددة، فلم تتنوع ألوان اللوحة لديه كما هو الثأن في لوحات القروي الفنية.

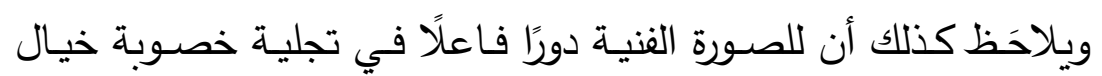
هذين الثـاعرين؛ فأظهرت مقدرتهما على التصـوير الجزئي، والإتيان بتشبيه مصيب، أو استعارة بارعة، أو كناية موحيـة، وبراعتهما في التصـوير الكلي الذي يضم عددًا من الصور الجزئية التي سرعان ما تتناغم وتتشـابك، وتتعاون

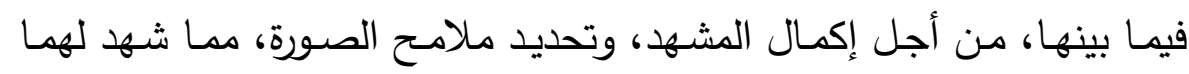
بالموهبة الفنية الرائقة، والبراعة التصويرية الفائقة. 
أثر التصوير البياني والتحسين البديعي هِّ أداء معنى الصفح فِ الشعر المهجري: القروي

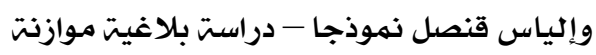

حوليت كليت اللغت العربيت بإيتاى البارود (العدد الثالث والثلاثون)

ثانيًا: سمات التحسين البليعي:

كانـت الموسـيقى التي تتمثل في المحسـنات البديعيـة بنوعيهـا: المعنويـة

واللفظية والتي كانت تعم القصيدتين لها سمات خاصة؛ إذ كان طابعها الغالب وسمْتها العام المحافظةَ والالتزام؛ أي المحافظة على الأوزان القديمة، والالتزام بتقاليد الثعر الموروثة، ومهما بدا في القصيدتين من سمات التتوع والتجديد لم تخرج غالبًا عن العرف الثعري القديم، فُعَُّّ ذلك حسنة من حسنات الثـاعرين، ومقدرة فنية تحسب لهما، إذ استطاعا - مع محافظتهما على التقاليد الثعرية الموروثـة - أن يُكسِبـا القصـيدتين الكثير مـن الطاقـات النغميـة، والترنيمـات الإيقاعية، فهَتُهها شـاعريتهما المرهفة وعواطفهما الصـادقة إلى أوزان وقوافٍ جسدت عمق تجرِتهما الشعورية، وصدق انفعالاتهما العاطفية. كذا موسيقى القصيدتين الداخلية لم تأت على وتيرة واحدة ونغمة مكررة، بل عمد الشـاعران إلى الاختلاف الصـوتي لتتويـع الموسيقى، وأحسنا تجاور الألفاظ لتُحدِث بتآلفها وانسجامها - وبما تشمله من أصوات - نغمًا موسيقيَّا رائعًا يكثف خبايا نفسَيْهما ويزيل الحجب عن مكامن شعورهما وانفعالاتهما.

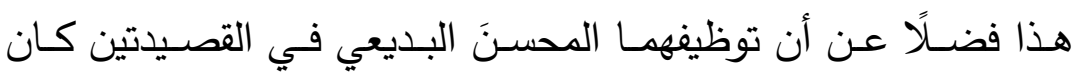
توظيفًا رائعًا؛ إذ كان يخدم المعنى غالبًا، ولم يهمل الألفاظ، فقد منح التحسين الألفاظ القوة والجزالة، وسلط الضوء على معنى الصفح والتسامح، خاصسة أن معظم المحسنات البديعية التي جاءا بها في القصيدتين قد جاءت بطبعهما غير متكلفة، فأحدثت نغمات محببة وإيقاعات منغمـة أطربت الآذان، وهزت عميق مشاعر الوجدان.

وقد تمحسور استخدامهما للمحسـنات البديعيـة حـول فنـون معينة، فلم يستعينا بكل المحسنات اللفظية والمعنويـة؛ أذ وجدا في البعض الذي أتيا بـه القدر الكافي لأداء الغرض المقصود. وقد أتت المحسنات منهما عفو الخاطر ، فلم يتكلفا الإتيان بمثل هذه 
أثر التصوير البياني والتحسين البديعي هِّ أداء معنى الصفح هٍِ الشعر المهجري: القروي

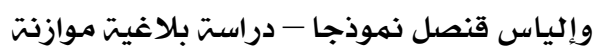

حوليت كليت اللغت العربيت بإيتاى البارود (العدد الثالث والثلاثون) الفنون، وإنما جاءت منهما طبعية عن غير قصد.

ومن الفنون التي اعتمدا عليها بكثرة في تحسين المعنى: الطباق والسجع والجناس والترصيع ومراعاة النظير والتتاسب والمقابلة. ومن المحسنات التي قل بل ندر استخدامهما لها: التقسيم والجمـع ورد ودرد العجز على الصدر وتصريع. وكما رأينا لم يحرص أحدُ منهما على الاستعانة بلون معين من الألوان

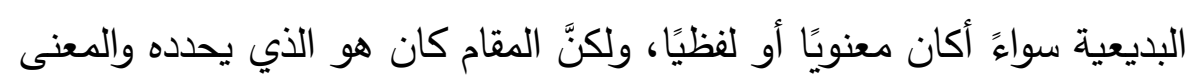

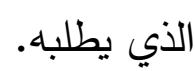

وقد لاحظنا أن هناك بعض المحسنات البديعية التي لم ترد منهما في

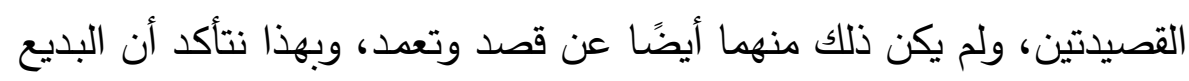

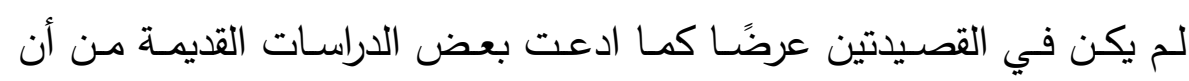

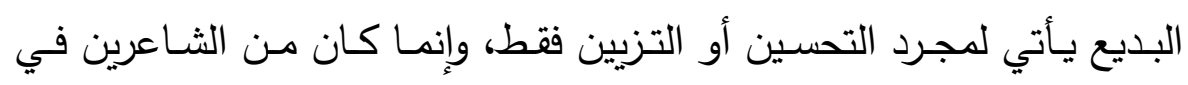
القصـيدتين غرضًا لإحـداث التماسـك بـين المقطوعـات داخـل القصـيدتين، ولتحقيق الترابط بين خيوطهما من أولهما إلى آخرهما، ولخلق الانسجام بين معانيهما وألفاظهما. وقد وجدنا كذلك أن البديع في القصيدتين قد أنتج الدلالة التي قصدها الثاعران، وقد نجحا في هذا نجاحًا عظيمًا، وظهر هذا جليًا في أثناء الدراسة.

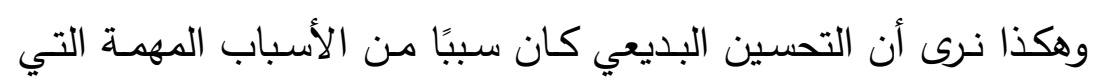
حقتت التماسك النصي والترابط المعنوي في القصيدتين. 
أثر التصوير البياني والتحسين البديعي ِِّ أداء معنى الصفح ِِّ الشعر المهجري: القروي

وإلياس قنصل نموذجا - دراست بلاغيتة موازنت

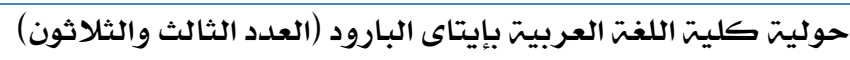

\section{الخاتمت}

الحمد الله حمدًا يليق بجلالهه، حمدًا كثيرًا طيبًا مباركًا فيه، والصـلاة والسـلام على خير خلقه، وصفوة رسله، وعلى آله وصحبه وسلم. وبعد:

فقد انتهيت من بحثي هذا بعد أن قضيت فيه وقت ليس بالقصير ، وبذلت فيه جهد ليس بالقليل. وقد أثمر البحث وحان قطاف الثر . بان. ومن النتائج التي توصلت إليها من خلال هذا البحث:

() كان للتصوير البياني والتحسين البديعي دورهما الكبير وأثرهما الفاعل فيل في إيضـاح معنى الصـفح والتسـامح، وإبـراز قدرات الثـاعرين الفنيـة وطاقاتهما التصويرية في القصيدتين، فلم تقف بلغتهما الثعرية عند حد المعنى المجرد والتعبير الجاف، بل نجدهما قد فجرا من اللغة طاقاتها

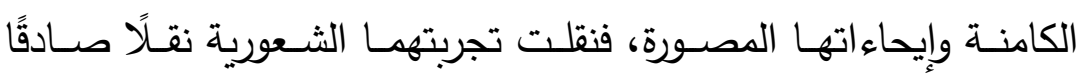

مؤثرًا.

r) تنوع التصسوير للى الثـاعرين في قصيدتيهما، فلم يقفا في تصـويرهما على لون بياني معين، بل نجدهما قد لجآ إلى كل فنون البيان كالتشبيه

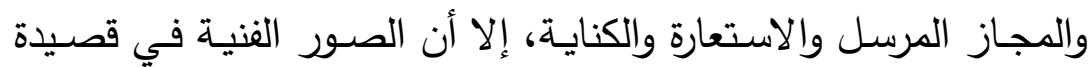
القروي كانت أكثر وأغزر ، كما لوحظ تعدد الصور الكلية في قصيدته ووجودها في أكثر من مقطوعة.

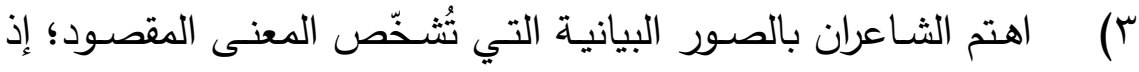
كانا يران أن الصورة قادرة على التعبير عن عواطف الثاعر، فجاءت معظم مقطوعاتهما في قصيدتيهما لوحات فنيّة مليئة بالحياة والحركة. ع) بـدا الثـاعران في هـاتين القصيدتين محسافظَين على الأوزان القديمـة، ملتزمَين بتقاليد الثـعر الموروثة؛ إذ اسـتخدما بحر الـوافر، وهـو مـن الهن 
أثر التصوير البياني والتحسين البديعي هِّ أداء معنى الصفح هٍِ الشعر المهجري: القروي

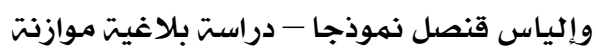

حوليت كليت اللغت العربيت بإيتاى البارود (العدد الثالث والثلاثون)

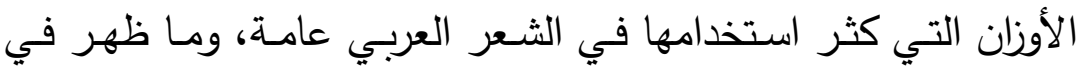
القصيدتين مـن سـمات التتـوع والتجديــ لـم يخرج عن العـرف الثـعري القديم، وهذه حسنة من حسناتهما ومقدرة فنية تحسب لهما. 0) إن توظيفهما للمحسن البديعي في القصيدة كان توظيفًا رائعًا، كان غالبًا مـا يخدم المعنى، ويسلط الضـوء على جانب مهم من جوانب التجربـة

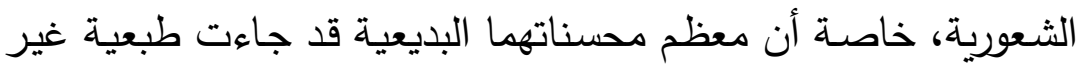

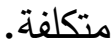

7) ابتعدا الثـاعران عن أسلوب الخطاب المباشر ، والاعتمـاد على أسلوب الهمس في التعبير ، مما جعل معانيهما وكلماتهما تدخل إلى النفس كما

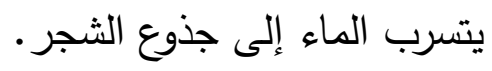

V) قد نأى الثاعران بنفسيهما عن التكلّف، وتمردا على الغرابة في استعمال

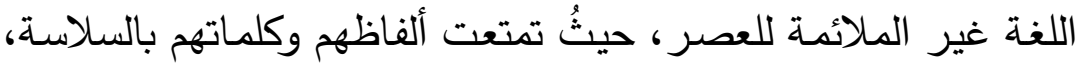

والرقة، والبساطة، إلى جانب تميزهما بجمال وبراعة التصوير •

^) دعا شعراء المهجر الجنوبي إلى الوحدة الموضوعيّة في القصيدة، ومنهم

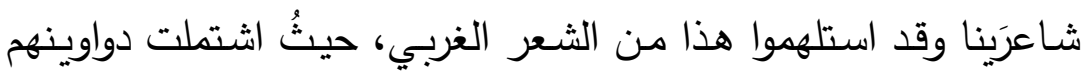
على مضمون واحد مرتبط ارتباطاً وثيقاً بالعنوان.

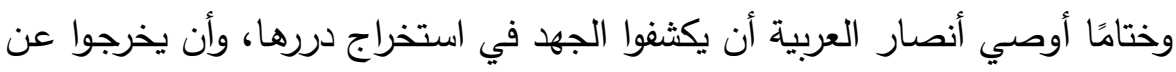

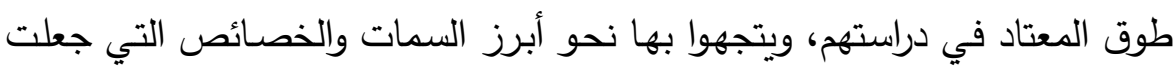

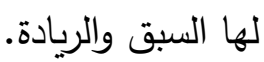

كمـا أوصسي الباحثين بالخوض في غمـار الثـعر المهجري، فبـه أسـرار كثيرة ولطائف عظيمة تحتاج إلى البحث والدراسة، فهو كالمياه الراكدة كلما حاولت تحريكها اتسعت دائرتها وحلقاتها، فعلى الرغم من الدراسات التي دارت حول الثعر لئه المهجري؛ إلا أنه فيه الكثير الذي لم تتناوله الدراسات السابقة.

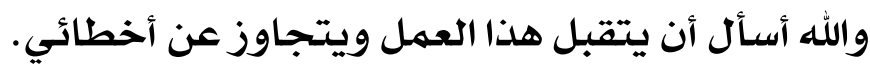

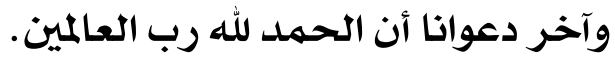


أثر التصوير البياني والتحسين البديعي ِِّ أداء معنى الصفح ِِّ الشعر المهجري: القروي

وإلياس قنصل نموذجا - دراست بلاغيت موازنت

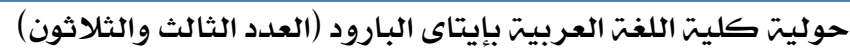

\section{فهرب المصادر والمراجع}

أولًا: الرسائل العلمية المطبوعة:

( ) إلياس قنصـل حياتهـ وشعره، أيمـن عثمان عبد العليم محمد، رسـالة ماجستير غير منشورة، كلية دار العلوم، جامعة القاهرة، ع . . Y.

r) الثعر العربي الحديث بين موسيقى العروض والإبداع الفني، محمد فايد

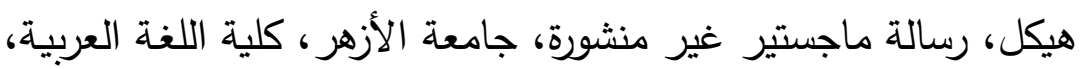

$$
\text { ثانتًا: الكتب المنشوط، بهو ام. }
$$

( ) أسرار البلاغة، عبد القاهر الجرجاني، تحقيق محمد عبد المنعم خفاجي،

$$
\text { مكتبة القاهرة، ط ب، } 9 \vee 9 \text { (م. }
$$

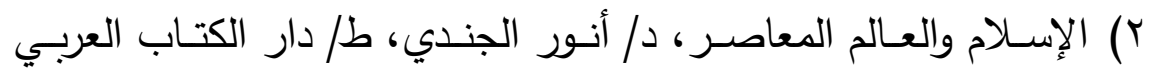

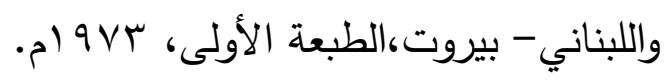

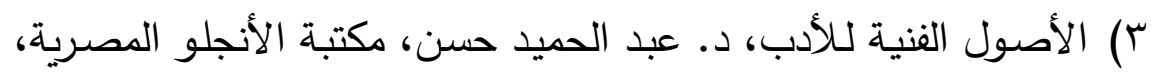

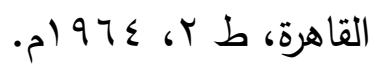

ع) الإنسان في الأدب الإسلامي، محمد عادل الهاشمي،ط/ مكتبة الطالب

$$
\text { الجامعي- العزيزية- مكة المكرمة، بدون تاريخ. }
$$

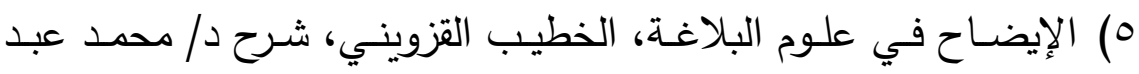

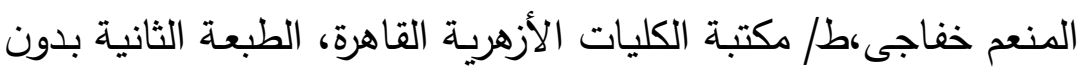

$$
\text { تاريخ. }
$$

7) بغيـة المشتاق إلى دراسـة علم الأخـلاق،د/ ثروت حسن عبد الرحمن

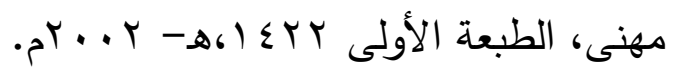

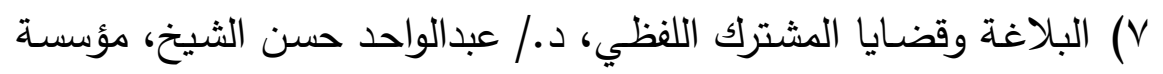
شباب الجامعة للنشر والتوزيع، 919 ام. 
أثر التصوير البياني والتحسين البديعي هِّ أداء معنى الصفح بِّ الشعر المهجري: القروي

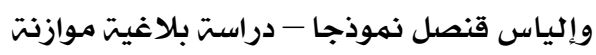

حوليت كليت اللغت العربيت بإيتاى البارود (العدد الثالث والثلاثون)

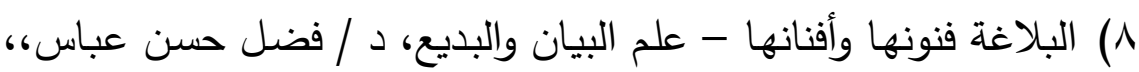

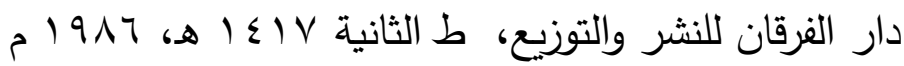

9) البديع رؤية جديدة، د / عبد الله دراز ، بدون تاريخ.

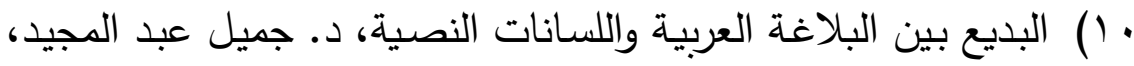

طبع الهيئة العامة للكتاب، 991 (م.

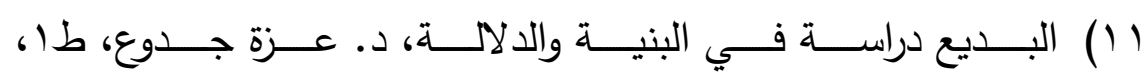

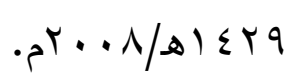

r ا البيان في ضوء أساليب القرآن، عبد الفتاح لاشين، دار الفكر العربي،

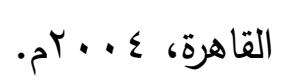

rا) اتجاهات النقد الأدبي في القرن الخامس الهجري، د. منصسور عبد

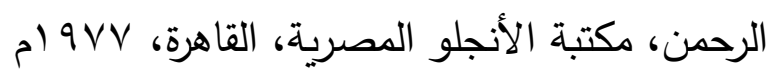

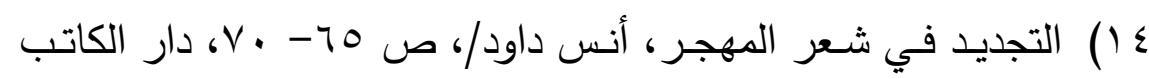

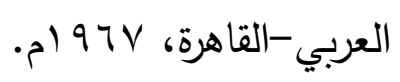

1) التجديد الموسيقي في الثعر العربي، د. رجاء عيد، منشأة المعارف، اهن

$$
\text { الإسكندرية، } 9 \Lambda \mathrm{V} \text { ام. }
$$

ד (1) تحرير التحبير في صناعة الثعر والنثر وبيان إعجاز القرآن، لابن الإن أبي الإصـبع المصري، تقديم وتحقيق د. حفني محمد شرف، ط لجنة

$$
\text { إحياء التراث الإسلامي، بدون تاريخ. }
$$

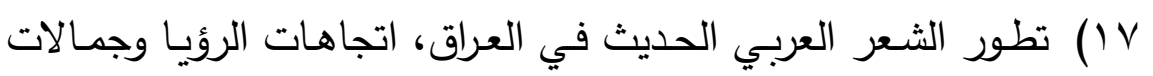
النص، د/ علي عباس علوان، ط/ دار الثؤون الثقافية العامـة، وزارة

الثقافة والإعلام ببغداد، بدون تاريخ.

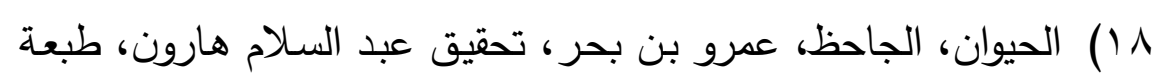

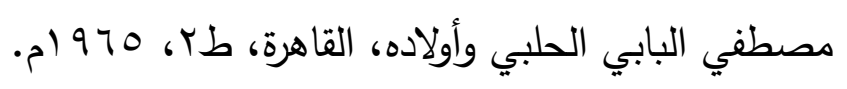


أثر التصوير البياني والتحسين البديعي هِّ أداء معنى الصفح بِّ الشعر المهجري: القروي

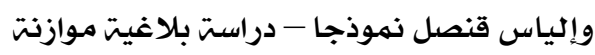

حوليت كليت اللغت العربيت بإيتاى البارود (العدد الثالث والثثلاثون)

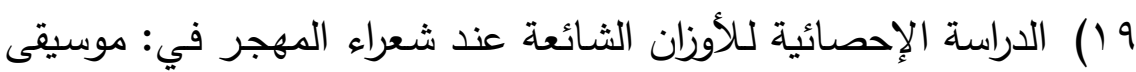

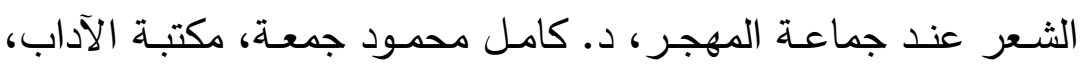

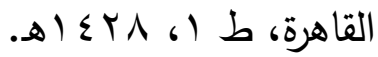

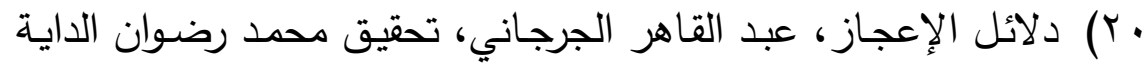

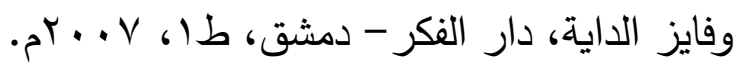

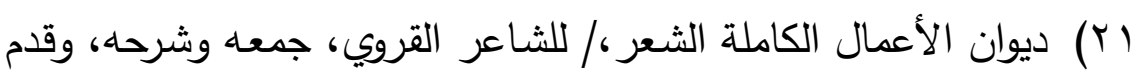
لـه مكتب التدقيق اللغوي، طا جروس بـرس -طـرابلس - لبنـان، بـدون

تاريخ.

r ا ديوان شوقي، توثيق وتبويب وشرح وتعقيب،د/ أحمد محمد الحوفي

ط/ دار نهضة مصر الفجالة. القاهرة بدون تاريخ.

rr) ديوان الأسلاك الشائكة، إلياس قنصل طار البرازيل.

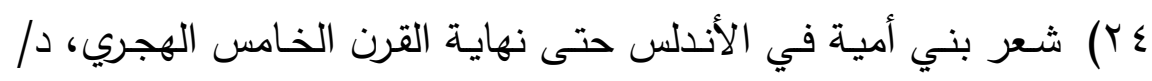

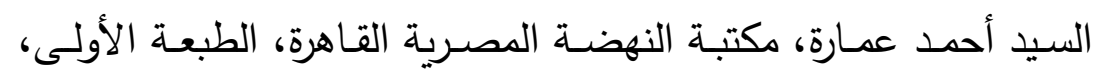

$$
\text { . } 990-81 \leq 17
$$

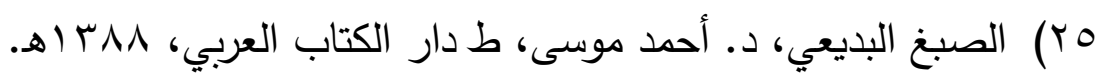

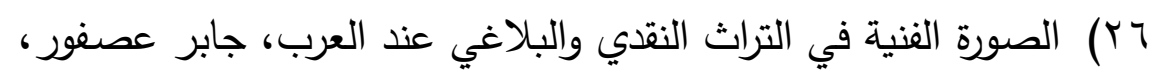
المركز الثقافي العربي، بيروت، طس، بو9 99 (م.

(YV

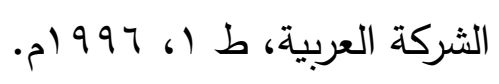

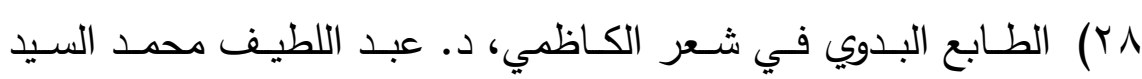

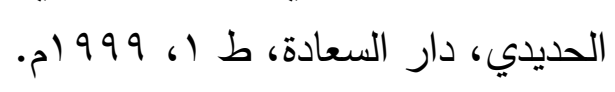

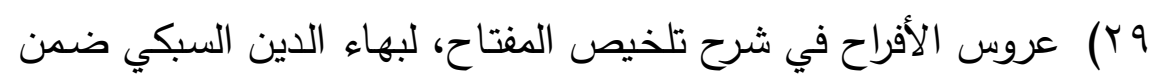
شروح التلخيص، ط دار الكتب العلمية بيروت، بدون تاريخ. 
أثر التصوير البياني والتحسين البديعي فِّ أداء معنى الصفح بِّ الشعر المهجري: القروي

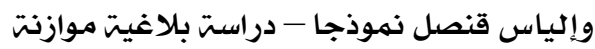

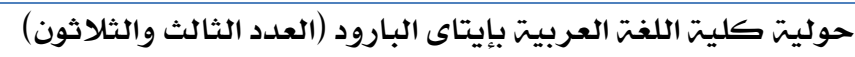

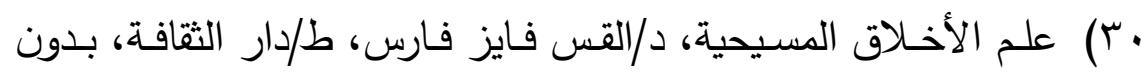
تاريخ.

(ب) علم الأسلوب، صلاح فضل، دار الثروق، القاهرة، طاه، 991 (م. rr) علم البديع دراسة تاريخية، وفنية لأصول البلاغة ،ووسائل البديع، أد. بسيوني عبد الفتاح فيود، بدون طبعة.

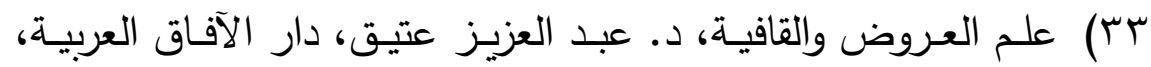

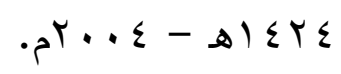

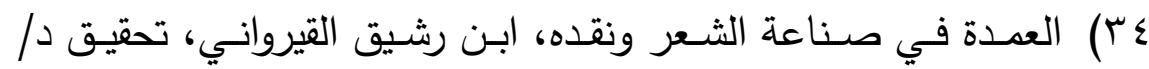
النبوي عبد الواحد شعلان، ط/ الشركة الدولية للطباعـة، الناشر مكتبة

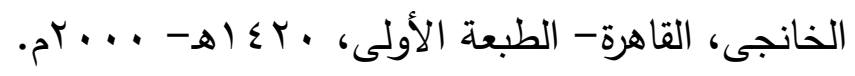

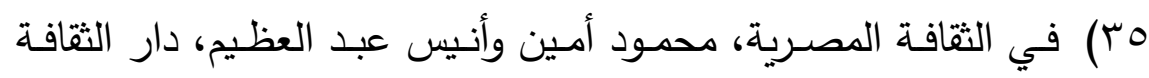
الجديدة، طץ، بدون تاريخ.

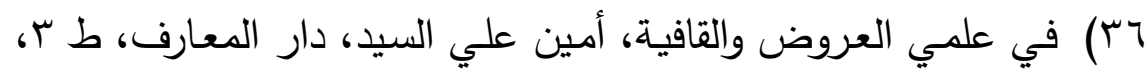
بدون تاريخ.

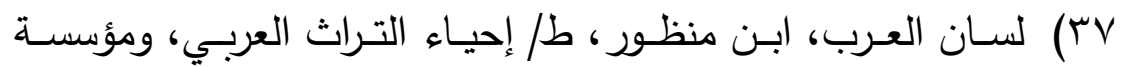
التاريخ العربي، بيروت- لبنان، الطبعة الثالثة، 9 إـ إهـ- 999 (م.

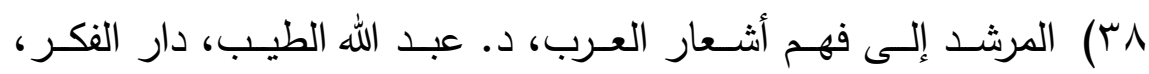

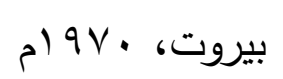

qr) مقدمة في علم الأخلاق المسيحية، د/ محمود حمدي زقزوق، ط/ دار

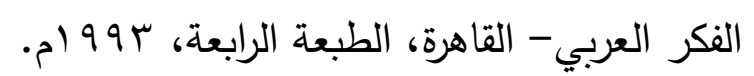

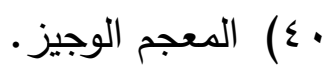
( ) ( ) المعجم الوسيط.

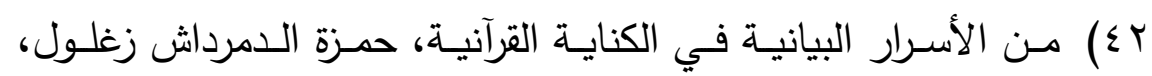

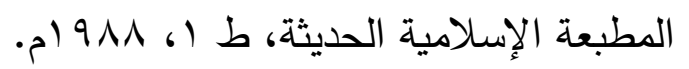


أثر التصوير البياني والتحسين البديعي ِِّ أداء معنى الصفح ِِ الشعر المهجري: القروي

$$
\text { وإلياس قنصل نموذجا - دراست بلاغيت موازنت }
$$

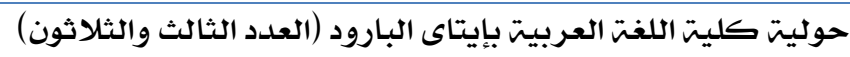

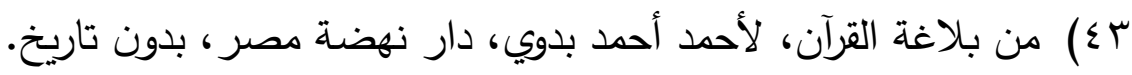

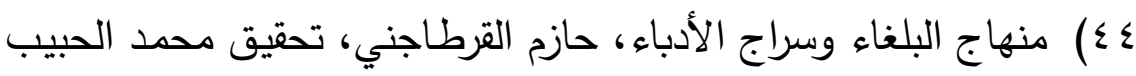

خوجة، دار الغرب الإسلامي، طبالقاهرة بدون تاريخ.

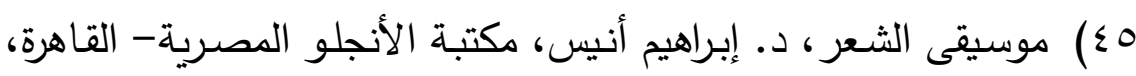

$$
\text { . } 99 \vee 6 \vee b
$$

ج؛) نظريـة النقد العربي - رؤيسة قرآنية معاصرة، محمد حسين علي، دار

$$
\text { المؤرخ العربي، بيروت، لبنان }
$$

( \&V العلمية، بيروت- لبنان، بدون تاريخ. 
أثر التصوير البياني والتحسين البديعي ِِّ أداء معنى الصفح ِِّ الشعر المهجري: القروي

وإلياس قنصل نموذجا - دراست بلاغيتة موازنت

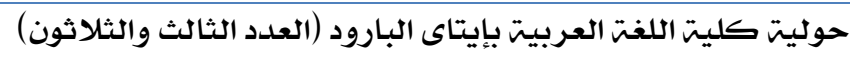

فهرب الموضوعات

\begin{tabular}{|c|c|c|}
\hline الصفحتَ & الموضوع & 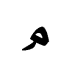 \\
\hline q وس & المقدمة & 1 \\
\hline r & التمهيد & r \\
\hline$r \leqslant$ & والتمسك بالعث التي حدت بشعراء المهجر إلى التحلي بالقيم & r \\
\hline$r \leqslant \Lambda$ & بين يدي الشاعرين & $\varepsilon$ \\
\hline ror & الصبحث الأول: أثر التصوير البياني في أداء معنى & 0 \\
\hline$\varepsilon .0$ & فيلاغية أداء معنى الصفث الثاني: أثر التحسين البديعي والنغم الموسيقي & 7 \\
\hline$乏 0 \wedge$ & البديث الثالث: سمات التصوير البياني والتحسين & $V$ \\
\hline$\leqslant\rceil \varepsilon$ & الخاتمة & $\wedge$ \\
\hline$\leqslant 77$ & فهرس المصادر والمراجع & 9 \\
\hline$\sum v 1$ & فهرس الموضوعات & 1. \\
\hline
\end{tabular}

